Portland State University

PDXScholar

Summer 8-5-2015

\title{
Glacier Change on the Three Sisters Volcanoes, Oregon: 1900-2010
}

Justin George Ohlschlager

Portland State University

Follow this and additional works at: https://pdxscholar.library.pdx.edu/open_access_etds

Part of the Geology Commons, and the Glaciology Commons Let us know how access to this document benefits you.

\section{Recommended Citation}

Ohlschlager, Justin George, "Glacier Change on the Three Sisters Volcanoes, Oregon: 1900-2010" (2015). Dissertations and Theses. Paper 2448.

https://doi.org/10.15760/etd.2445

This Thesis is brought to you for free and open access. It has been accepted for inclusion in Dissertations and Theses by an authorized administrator of PDXScholar. Please contact us if we can make this document more accessible: pdxscholar@pdx.edu. 
Glacier Change on the Three Sisters Volcanoes, Oregon: 1900-2010

by

Justin George Ohlschlager

A thesis submitted in partial fulfillment of the requirements for the degree of

Master of Science

in

Geology

Thesis Committee:

Andrew G. Fountain, Chair

Jim E. O'Connor

Scott F. Burns

Portland State University

(C) 2015 


\begin{abstract}
A glacier responds to changes in climate by subsequent retreat and advance as a result of changes in snow inputs and outputs. Understanding these changes is important because shrinking glaciers limit and diminish local water resources. They contribute to alpine runoff in the late-summer months by delaying the maximum runoff until late in the melt season. A comprehensive glacier and perennial snowfield inventory has not been completed for the Three Sisters in Central Oregon. Using aerial photography, Digital Elevation Models (DEMs), previous studies, and historical ground based photographs these glacier and perennial snowfields were defined and their surface area change was quantified along with surface area and volume change for the 15 named glaciers for multiple years. The glaciers and perennial snowfields totaled $9.03 \pm 1.65$ $\mathrm{km}^{2}$ in 1949 and decreased to $7.1 \pm 1.16 \mathrm{~km}^{2}$ in 2003 giving a total loss of $-1.914 \pm 0.974$ $\mathrm{km}^{2}(-21 \%)$. The 15 named glaciers totaled $12.43 \pm 0.417 \mathrm{~km}^{2}$ in $\sim 1900$ and decreased to $5.65 \pm 0.135 \mathrm{~km}^{2}$ in 2003 giving a total loss of $-6.70 \pm 0.439 \mathrm{~km}^{2}(54 \%)$ with more loss occurring in the early part of the century. It's estimated that the 15 named glaciers lost roughly $61 \%$ of volume from 1900 to 2010 . From 1957 to 2010 their surface's dropped in elevation on average by $-8.9 \mathrm{~m}$, losing an estimated $71.96 \times 10^{6} \pm 2.87 \times 10^{6} \mathrm{~m}^{3}(53 \%)$ in total volume, seen across accumulation and ablation zones, with more loss happening from 1957 to 1990 . There was no relationship found between topography and area. A small correlation was found between slope and increased volume change. Debris cover on glacier surfaces has increased and showed a correlation between decreasing area loss (no correlation with volume changes).
\end{abstract}




\section{Acknowledgements}

I would like to first thank my advisor Andrew Fountain. Thank you for your

guidance, knowledge, humor, patience, financial support, and motivation throughout this entire process. Thank you to Jim O'Connor and Scott Burns for the material, thoughts, and encouragement. I would also like to acknowledge the Geology Department at Portland State. Thank you for the educational and financial support.

A big thank you goes to all of the S-7 officemates Gunnar, Hassan, Kelly, Kristina, and Steve. Our talks and brain sessions helped immensely, especially when it came to volume change uncertainty.

I would like to thank The Mazamas Research Committee for funding this project; your funds were beneficial in completion of this thesis.

Last, but certainly not least, I would like to thank my family and friends for your encouragement, questions, and patience over the past few years. You have no idea what it means to me to be able to answer, "it's finished", to the simple question of... "How's the thesis coming?". 


\section{Table of Contents}

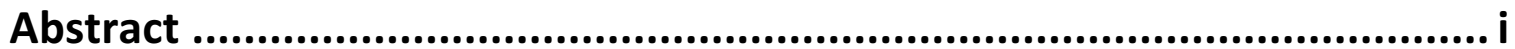

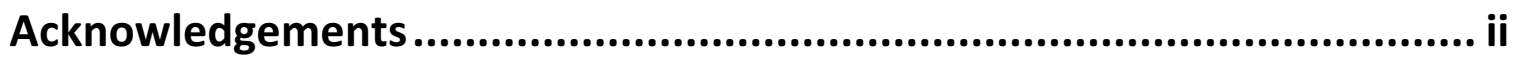

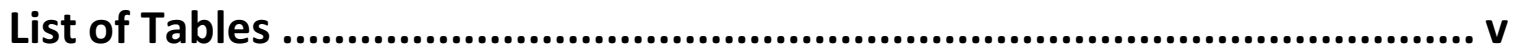

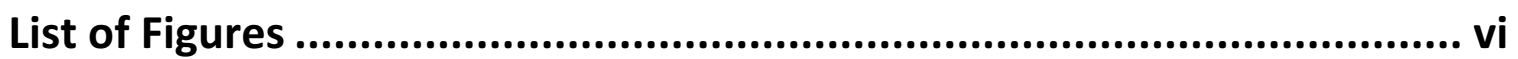

Chapter One - Introduction ................................................................... 1

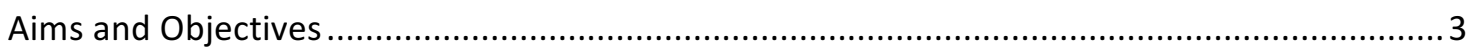

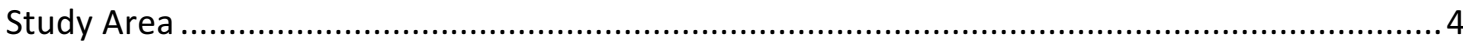

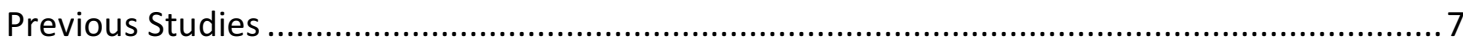

Chapter Two - Glacier Inventory ................................................... 10

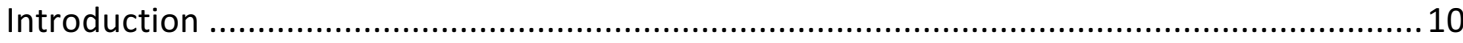

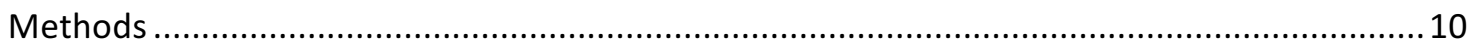

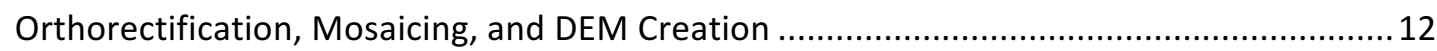

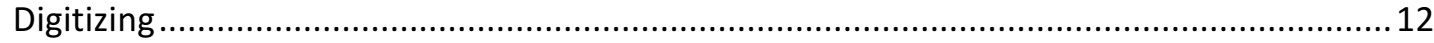

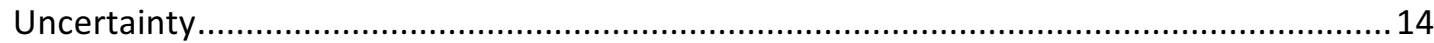

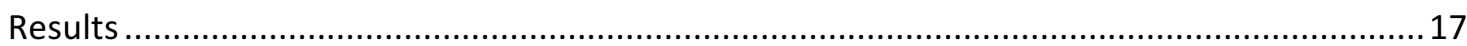

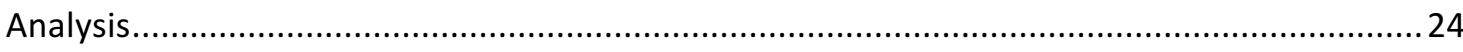

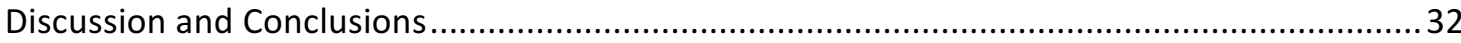

Chapter Three - Temporal Area Change ............................................. 36

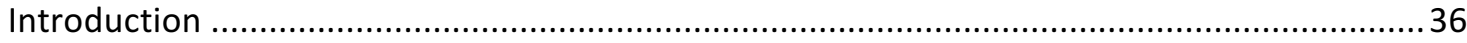

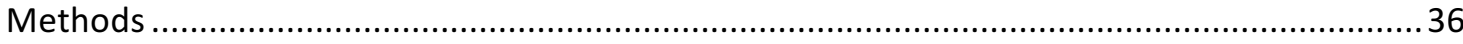

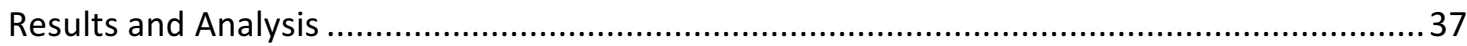

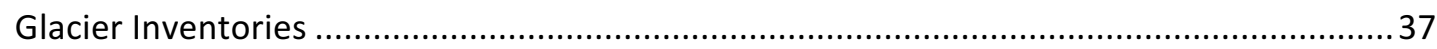

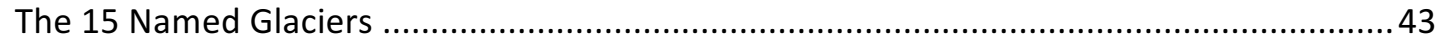

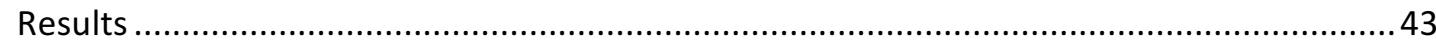

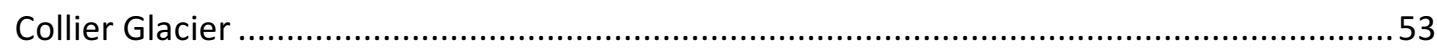

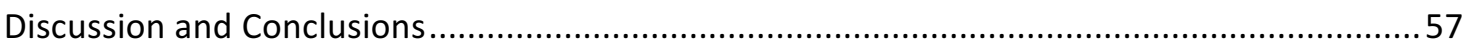

Chapter Four - Volume Change .............................................................. 60

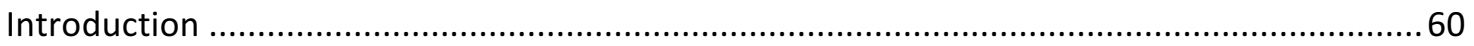

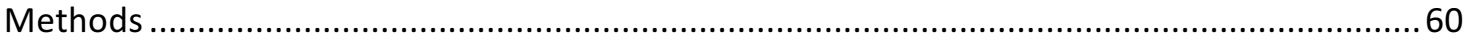

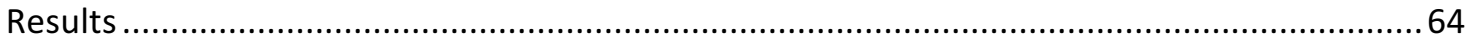




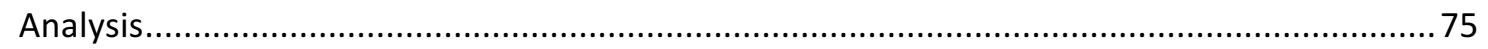

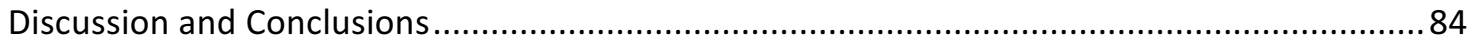

Chapter Five - Historic Photos .......................................................... 88

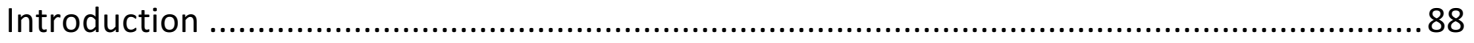

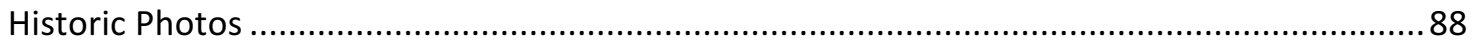

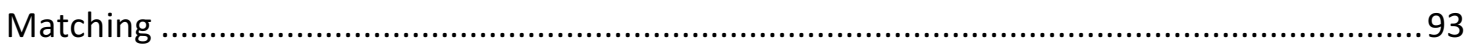

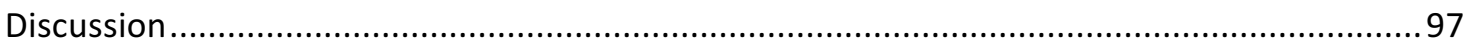

Chapter Six - Discussion and Conclusions .......................................... 99

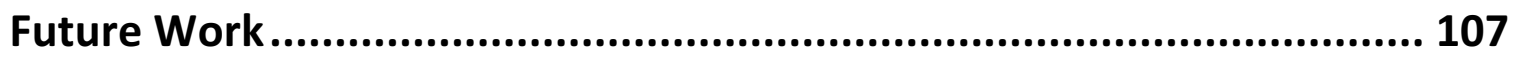

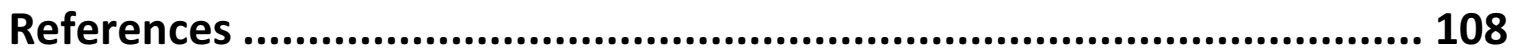

Appendix A - LIA Glacier Outline Inventories Maps ............................. 114

Appendix B - Glacier Inventories Features......................................... 116 


\section{List of Tables}

Table 1. Imagery and digital elevation model (DEM) used to compile the glacier inventories and orthorectification process.

Table 2. The number of total features, seasonal snowfields, glacier and perennial

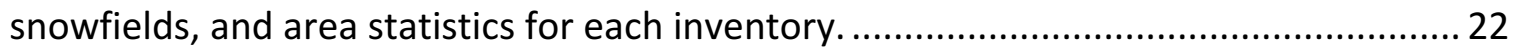

Table 3. Comparison of features that are $<0.05 \mathrm{~km}^{2},<0.1 \mathrm{~km}^{2}$, and $>0.1 \mathrm{~km}^{2} \ldots \ldots \ldots \ldots . . . .27$

Table 4. The comparison of my estimated average thicknesses in 1990 (shear stress) to the calculated thicknesses by Driedger and Kennard (1986) for the Collier, Prouty, Hayden, and Diller glaciers.............................................................................. 28

Table 5. Comparison of the total glacier and perennial snowfield statistics and glaciers determined by the basal shear stress threshold........................................................... 29

Table 6. Comparison of the glacier area thresholds $\left(0.05\right.$ and $\left.0.1 \mathrm{~km}^{2}\right)$ to the shear stress

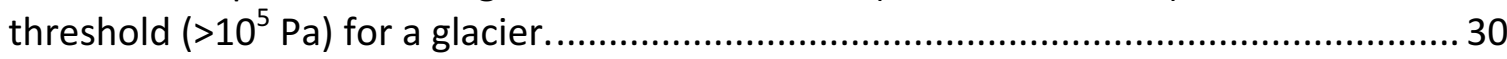

Table 7. Glaciers that passed the area threshold $\left(0.1 \mathrm{~km}^{2}\right)$ and/or the basal shear stress

threshold. 32

Table 8. Imagery and previous studies used in this study for examining the 15 named glaciers.

Table 9. Area change based on inventory glaciers on the Three Sisters........................ 38

Table 10. The distribution of glacier and perennial snowfields with significant area change for the five time periods.

Table 11. The magnitude of variability of significant area change for glaciers and perennial snowfields for the 5 inventory comparisons.

Table 12. Area, average elevation, elevation difference, average slope, and average aspect of the 15 named glaciers.

Table 13. Named glaciers with the number of extents and the year.

Table 14. Comparison of the 15 named glaciers LIA areas from the digitized areas and

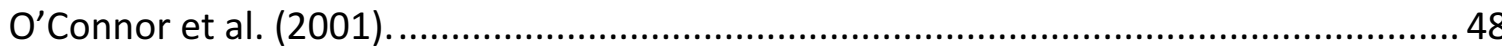

Table 15. Areas for the 15 named glaciers.

Table 16. Updated areas $\left(\mathrm{km}^{2}\right)$ of the 15 named glaciers from estimated (Italics and bold) areas for 1925 and 1937 for the using Collier as a reference.

Table 17. Areas and difference $\left(\mathrm{km}^{2}\right)$ of the 15 major glaciers from Hodge (1925) and calculated areas for 1925 using Collier as a reference.

Table 18. Root mean square error (RMSE) and pixel count per slope bin from the uncertainty estimates for the surface change

Table 19. Volume change estimates from 1957-2010 with specific volume change and percent uncertainty of volume change for the glaciers on the Three Sisters Volcanoes. 67 Table 20. Volume change estimates from 1957-1990 with specific volume change and percent uncertainty of volume change for the glaciers on the Three Sisters Volcanoes. 69 Table 21. Volume change estimates from 1990-2010 with specific volume change and percent uncertainty of volume change for the glaciers on the Three Sisters Volcanoes. 70 Table 22. Photo list of the glaciers on the Three Sisters presented in this chapter.... 88 


\section{List of Figures}

Figure 1. Digital elevation map (USGS, 2010) of the Three Sister Volcanoes, Central Oregon Cascade Range.

Figure 2. Photo looking to the south towards Collier Glacier and Middle Sister with the black and white arrows pointing to the moraine crests of the LIA advance.

Figure 3. Photograph of the Diller Glacier (foreground) taken by I.C. Russell August 16, 1903 looking south with the summit of South Sister (background).

Figure 4. Examples of the presence and lack of landscape modification due to perennial snow or ice.

Figure 5. Examples of interpretation uncertainty.

Figure 6. Specific zones on the 1959 1:62,500 scale map, imagery date 1957, (left) and the $19881: 24,000$ scale map imagery date 1957 with limited revision from photos taken in 1979-1982 (lower right) where the glacier outlines have been updated.

Figure 7. National Elevation Dataset Digital Elevation Model (USGS, 2010) map of the Three Sisters Volcanoes showing the glaciers and perennial snowfields (in black) from the combined outlines from the inventories of 1949, 1957, 1990, and 2003.

Figure 8. The population distribution of glacier and perennial snowfield area for the inventories.

Figure 9. Topographic characteristics of the 1957 (left graphs) and 1990 (right graphs) glacier inventories mean elevation, mean slope, and aspect plotted for number (solid bars) and area $\left(\mathrm{km}^{2}\right)$ (hatched bars).

Figure 10. The fractional uncertainty of the glacier and perennial snowfields for the inventories.

Figure 11. The location of the 21 glaciers identified by either the sheer stress or area threshold.

Figure 12. Histograms of the significant area change.

Figure 13. The fractional area plots for significant change glacier and perennial snowfields for 1949-1957, 1957-1990, 1949-1990, 1949-2003, and 1990-2003.

Figure 14. Location of the 15 named glaciers, in black, on the Three Sisters in 1957. .... 43 Figure 15. Cumulative area total of the glacier inventory in 1957 with the 15 named glaciers in red.

Figure 16. Glacier area change for North \& Middle (top two) and South (bottom two)

Sisters expressed in area change $\left(\mathrm{km}^{2}\right)$ and fractional area change. 50

Figure 17. Glacier area change (1900-2003) as a function of average elevation, slope, aspect, and elevation difference.

Figure 18. Effect of debris-cover on glacier change.

Figure 19. FAC based on 1900 area and change percentages of Collier Glacier from 1900 to 2007 showing the calculated changes between years of area data.

Figure 20. Locations of the control zones (hatched marked zones) for the volume change analysis used for 1957-2010.

Figure 21. Locations of the control zones (hatched) for the volume change for 19571990 ad 1990-2010. 
Figure 22. Root mean square error (RMSE) uncertainty (black) and pixel count (blue and red) for a) 1957-2010 North \& Middle and South Sisters, b) 1957-1990, c) 1990-2010 binned by slope shows a nonlinear increase of uncertainty as the slope increases. ....... 65 Figure 23. Total volume (filled bars) and specific volume change (open bars) from 19572010 shows the average thickness change average across the glaciers North \& Middle Sisters and South Sister glaciers.

Figure 24. Total volume (filled bars) and specific volume change (open bars) from 19571990.

Figure 25. Total volume change and specific volume change from $1990-2010 \ldots \ldots \ldots . . . . . .71$

Figure 26. Difference maps showing the spatial distribution of elevation change $(\mathrm{m})$ from 1957-2010, 1957-1990, and 1990-2010 15 named glaciers on North \& Middle

Sister...

Figure 27. Maps showing the spatial distribution of elevation change $(\mathrm{m})$ of the 15 named glaciers on South Sister.

Figure 28. The spatial distribution of elevation change of the 15 named glaciers on the Three Sisters with statistically insignificant volume change zones in gray.

Figure 29. Map showing location of substantial thinning, $45-50 \mathrm{~m}$, on the Collier and Diller glaciers from 1957-2010. 75

Figure 30 Comparison of the Collier Glacier from September 21, 1960 (Top left, photo taken by Austin Post) and August 24, 2007 (Top right, photo taken by John Scurlock)... 76 Figure 31. Specific volume change (1957-2010) as a function of elevation and slope. . 77 Figure 32. Specific volume change (1957-2010) as a function of average aspect and elevation difference. 78

Figure 33. Specific volume change (1957-2010) as a function of debris cover. 79

Figure 34. Maps showing the spatial distribution of elevation change of the 15 named glaciers on the Three Sisters with Slopes above $40^{\circ}$ green.

Figure 35. Volume change (1957-2010) as a function of area change............................ 81

Figure 36. Specific volume change (left) and fractional volume change (Right) from 19572010 as a function of elevation for the North \& Middle Sister glaciers (Top) and South Sister glaciers (bottom).

Figure 37. Clockwise from top, photo taken August 16, 1903 looking southeast towards Diller Glacier (foreground and Broken Top (background).

Figure 38. Aerial photographs (Photograph taken by A.J. Gilardi) of the Diller (left) and Hayden (right) glaciers taken September 24, 1937 funded by the Research Committee of the Mazamas (sourced by the Mazamas). 91

Figure 39. Historic photos of the Three Sisters and its glaciers. 92

Figure 40. Ruth Hopson Keen photos of Collier Glacier taken from Collier Cone looking South towards Middle Sister.

Figure 41. A) Photo of Collier Glacier Taken by Clarence Winters, August 1910, matched by Dave Wieprecht from Little Brother looking South towards Middle Sister. B) Photo taken by IC Russell August 16, 1903 with photo matches by David Weiprecht on August 16, 2003 and Jim O'Connor on August 17' 2013. All Photos were sourced by Dr. Jim O'Connor at the USGS. 
Figure 42. Photo matches of historic photos taken of the Three Sisters and its glaciers. 96 


\section{Chapter One - Introduction}

Glaciers occur in the alpine regions where the accumulation exceeds ablation.

The two main controlling factors are winter snowfall and summer air temperature, which make glaciers good recorders of regional climate changes (Dyurgerov and Meier,

2000; Oerlemans, 2005). A glacier responds to changes in climate by subsequent retreat and advance as a result of changes in the mass inputs and outputs (Hodge, et al., 1998; Hall and Fagre, 2003). Due to the remoteness of alpine regions, they can be good recorders of past climates where few records exist. Since the end of the Little Ice Age (LIA), approximately 150 years ago (Grove, 1988), glaciers have experienced an alternating retreat - advance - retreat cycle with glaciers developing an overall retreat by losing both volume and area (Haeberli, 1995). Shrinking glaciers limit and diminish local water resources. Glaciers are major contributors to alpine runoff in the latesummer months when the need for water is the greatest (Fountain and Tangborn, 1985; Fountain et al., 1997). While glacier shrinkage removes ice from long-term storage and exports it as runoff, supporting drought-affected stream flow, smaller glaciers have reduced capacity to export the water volume needed to maintain flows at historic levels. Increased frequencies of debris flows are associated with retreating glaciers on volcanoes (Pirot, 2010; Legg, 2013). With glacier retreat an increase frequency of debris flows could occur due to glaciers no longer buttressing unconsolidated sediments on lateral moraines (O'Connor et al., 2001). In the Pacific Northwest (PNW) of the United States glaciers have also been losing both area and volume in recent decades (McCabe 
and Fountain, 1995; McDonald, 1995; Jackson and Fountain, 2007; Marcott et al., 2009;

Sitts et al., 2010; Sisson et al., 2011; Dick, 2013; McCabe and Fountain, 2013).

In Oregon, weather patterns are influenced by two primary modes of climatic patterns: the interannual El-Nino Southern Oscillation (ENSO) and the decadal Pacific Decadal Oscillation (PDO) (Mass, 2008). Warm phase ENSO winters have warmer and drier winters and the snowpack thickness is less than average. Cool phase ENSO winters have cooler and wetter winters and snowpack thicknesses are greater than average. PDO warm phase produces cooler sea surface temperatures in the Central North Pacific and warmer temperatures near the coast (Mass, 2008). In a warm PDO phase snowpack thickness in the PNW are below average. The PDO cool phase produces the opposite sea surface temperatures and about average snowpack (Zhang et al., 1997; Chao et al., 2000). Snow water equivalents (the mass of water contained in a snowpack as snow) in the PNW have declined over the past half-century as a result overall increases in air temperature (Mote, 2003; Hamlet et al., 2005; Mote, 2006). An increase in winter temperature causes more precipitation to fall as rain more frequently than snow reducing the winter snow pack thickness resulting in less nourishment to the glacier. The winter snowpack also melts off the glacier sooner allowing for the melt of ice, stored in the glacier to start sooner. This all affects the mass balance of glaciers and has implications on water resources.

Changing glacier area and volume have been examined for many of the Cascade volcanoes and alpine regions of the PNW: Mount Rainier (Driedger and Kennard, 1986; Nylen, 2001, Sisson et al., 2011); Mount Adams (Sitts, et al., 2010); Mount Hood 
(Jackson and Fountain, 2007); and the North Cascades (Granshaw and Fountain, 2006;

Dick, 2013). Area change can be readily quantified from aerial and ground-based photographs and satellite imagery (Fountain et al., 1997). However, a comprehensive assessment of area change for glacier and perennial snow patch areas has not been completed for the Three Sisters. An assessment of volume change is also a useful metric to link glacier change to climate and to alpine stream flow. Area changes can be noisy indicators due to the dynamics of glacier response to mass input and area-volume relations which are not constant over time (Dyurgerov et al., 2009). Knowledge of volume change over the past century can provide a more accurate assessment of glacier change in response to climate.

\section{Aims and Objectives}

Ample data exist for the Three Sisters from which inventories on the changes in glacier area and volume can be created. My thesis provides an extensive examination of the glaciers and snowfields changing area and volume, and how it compares to other regions around the PNW and the world.

This thesis is divided into six chapters. Following the introduction, Chapter Two presents the glacier and perennial snowfield inventories from 1949, 1957, 1990, and 2003, with topographic characteristics for 1957 and 1990. Chapter Three outlines the temporal change for the glacier's area. Chapter Four presents the temporal volume change and focuses in on Collier Glacier as an 'index' glacier. Chapter Five is a presentation of historic and current glacier photographs and an assessment of 'matching' photographs, and Chapter Six contains the discussions and conclusions. 


\section{Study Area}

The Three Sisters Volcanoes, North (3074 m), Middle (3062 m), and South (3157

m) (Figure 1), are stratovolcanoes set within the Cascade Mountain Range that extend

from Northern California to Southern British Columbia Canada.

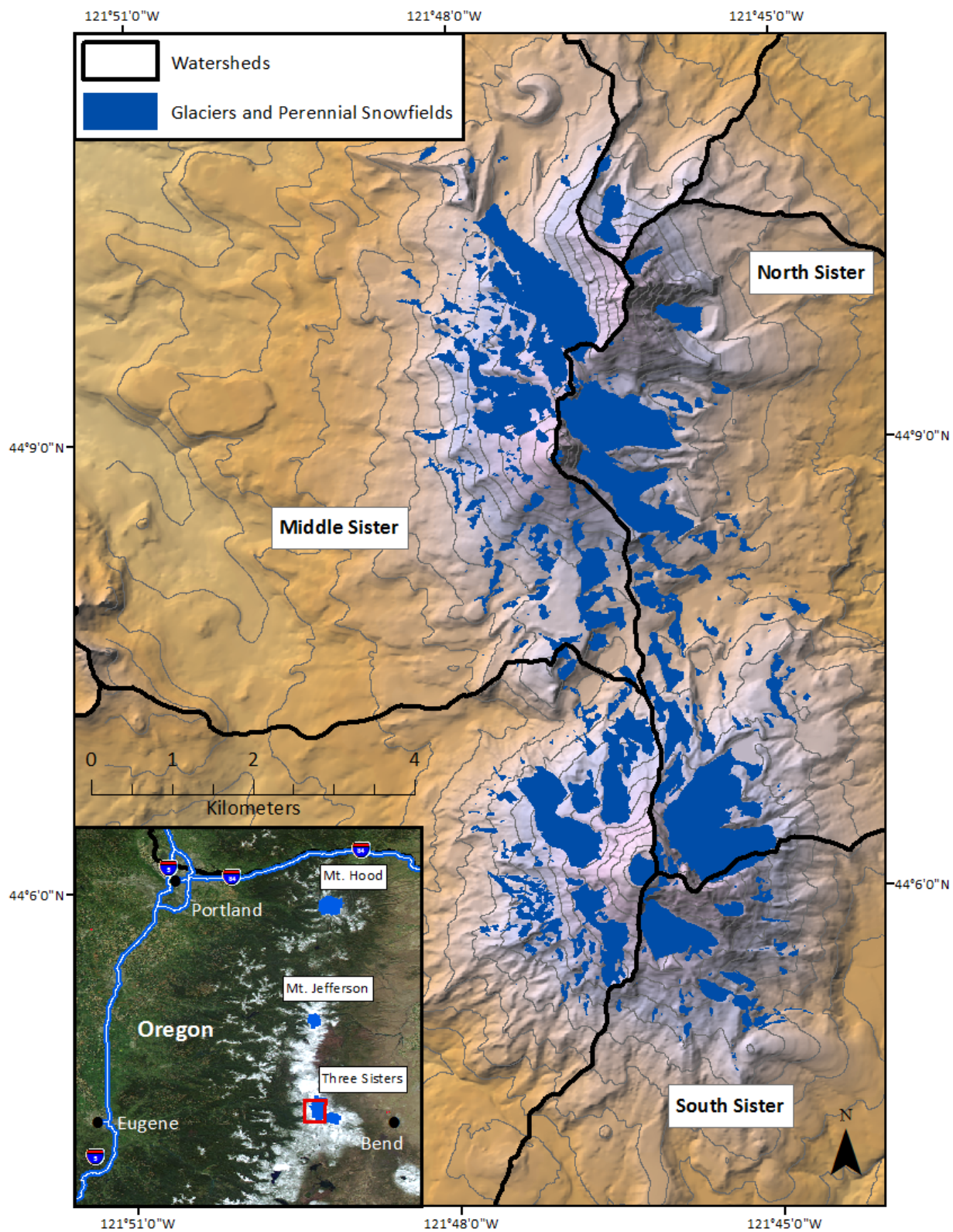

Figure 1. Digital elevation map (USGS, 2010) of the Three Sister Volcanoes, Central Oregon Cascade Range. Displayed are the location of the glaciers and perennial snowfields (in blue) and watershed boundaries (in black). Glacier and perennial snowfields are a combination of surface areas from 19492003. Contour interval is $100 \mathrm{~m}$. Map is in WGS 84 UTM Zone 10. 
They are located in the High Cascades of Central Oregon (44.123 N and 121.777 W), about $40 \mathrm{~km}$ west of Bend, Oregon. The volcanoes are within the Three Sisters Wilderness Area in both the Willamette (on the west flanks) and Deschutes (on the east flanks) national forests. A majority of the three edifices rise above treeline which is roughly $2500 \mathrm{~m}$ above sea level, with mountain hemlocks and white bark pine dominating the subalpine forests (O'Connor et al., 2001).

The volcanoes are primarily pyroclastic ejecta and lava flows composed of basalt, basaltic andesite, andesite, and dacite erupted during the middle Pleistocene $(\sim 720,000$ years old) with South Sister having a more recent volcanic history with eruptions occurring from 12,000 to 1,900 years before present (Wozniak, 1982). With exception of the recent volcanism, glacial modifications dominate the landscape ( $\mathrm{O}^{\prime}$ Connor et al., 2001). Three sets of moraines have been identified since the last glacial maximum (19$23 \mathrm{ka}$ ); oldest moraines $>8.1 \mathrm{ka}$, a second set from 2 to $8 \mathrm{ka}$, and the third from the LIA (Marcott et al., 2009). They are the result of multiple glaciations during the Holocene with the most recent maximum culminating the LIA sometime between 1850 and 1900 (Sigafoos and Hendricks, 1972; Crandell and Miller, 1974). These non-vegetated unconsolidated moraine deposits of the LIA are dominant features on the volcanoes pointing to the evidence of recent glacial fluctuations (Figure 2).

There are 15 named glaciers on the three volcanoes. Collier, Linn, Thayer, and Villard glaciers are located on North Sister. Diller, Hayden, Irving, and Renfrew glaciers are located on Middle Sister. Carver, Clark, Eugene, Lewis, Lost Creek, Prouty, and Skinner glaciers are located on South Sister. 
Oregon's weather is dominated in summer by a strong East Pacific High pressure system in the Pacific bringing dry stable air into the region (Mass, 2008). This brings sinking air with little cloud formation and almost no precipitation. In winter the East Pacific High weakens to the South, and the Aleutian Low pressure intensifies in the North Pacific bringing storms in off the Pacific moving east towards the Cascades (Mass, 2008).

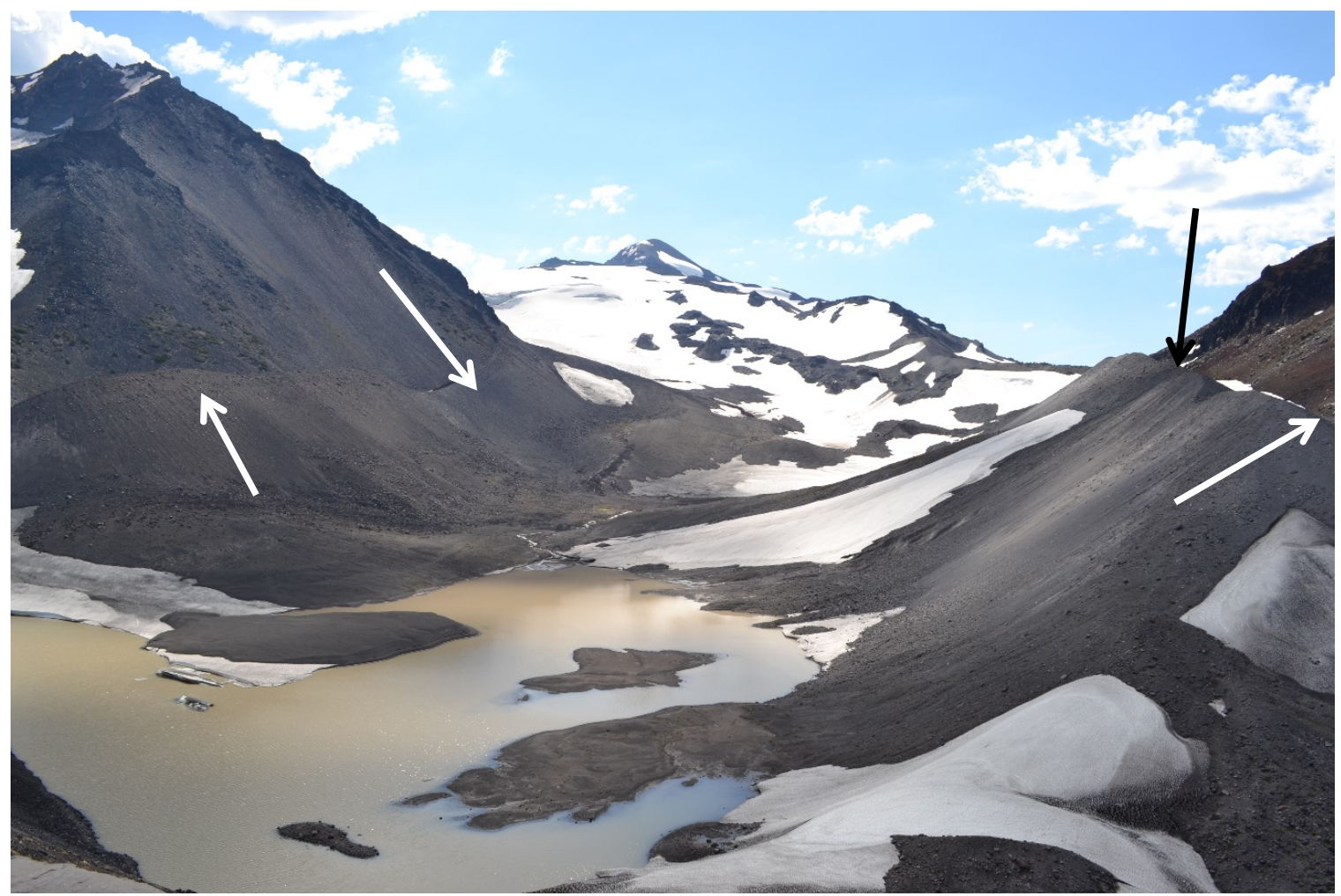

Figure 2. Photo looking to the south towards Collier Glacier and Middle Sister with the black and white arrows pointing to the moraine crests of the LIA advance. Photo: Justin Ohlschlager September 7, 2011.

The mountains orographically uplift the moist air causing it to condense and precipitate (Ruffner, 1985; Mass, 2008). About $90 \%$ of the precipitation falls in the fall, winter and spring months. Annual average precipitation in the region varies from 2500 to $3500 \mathrm{~mm}$ falling mainly in the winter months as snow (Taylor, 1993). The glaciers and perennial 
snowfields on the western flanks of the Three Sisters feed into the McKenzie River which drains into the Willamette River and on the eastern flanks into the Deschutes River.

\section{Previous Studies}

Glaciers were first observed on the Three Sisters by J.S. Diller in the summer of 1883 on an expedition to the summits of Mt. Thielsen, Diamond Peak, and the Three Sisters (Russell, 1885). Russell noted that Diller observed a number of considerable glaciers on multiple Cascade peaks that included the Three Sisters. Russell (1905) is the first report on the glaciers and included photographs and observations. He noted their current surface being lower than the adjacent moraine crests (Figure 3). Later Hodge (1925), reported on glacier areas, photography, climbing routes, and a history of the glacier names. Each glacier is described in the report, but there is no mention of how glacier area was estimated. 


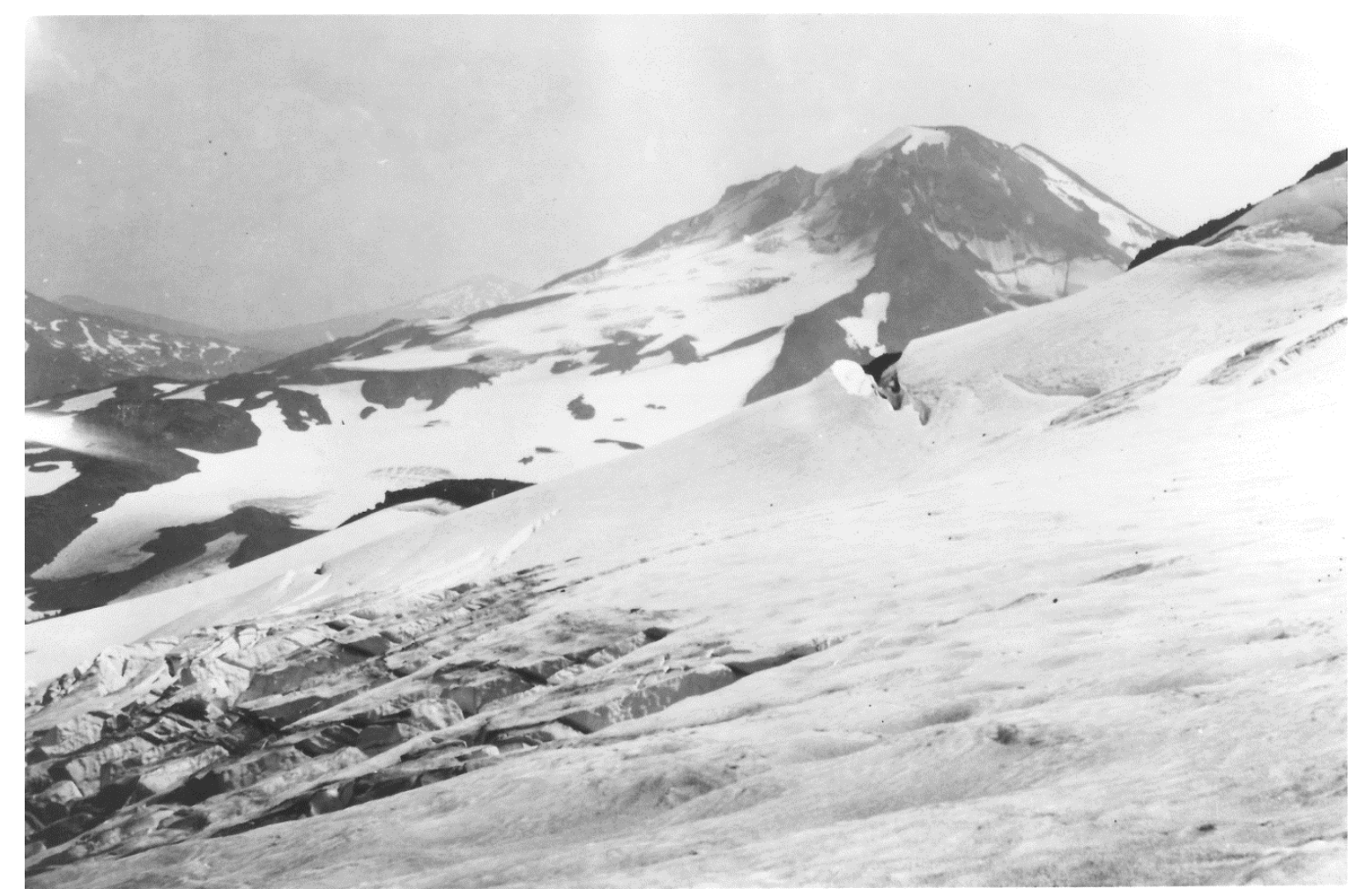

Figure 3. Photograph of the Diller Glacier (foreground) taken by I.C. Russell August 16, 1903 looking south with the summit of South Sister (background). Photo Source: Jim O'Connor USGS.

Many comprehensive reports and photographs of the Three Sisters glaciers in the early $20^{\text {th }}$ century have been published by the Mazamas, a hiking club in Portland, Oregon (Williams, 1916; Phillips, 1938; Hopson, 1960; Hopson, 1962; Hopson, 1963; Hopson, 1965). Most studies have focused on the Collier Glacier, on the north flank of Middle Sister, with little attention to the changes of the other glaciers (Driedger and Kennard, 1986; McDonald, 1995; O’Connor et al., 2001; Fountain et al., 2007; Beedlow, 2010). A partial inventory of the glaciers was completed using ground-penetrating radar and area-volume estimates (Driedger and Kennard, 1986). Area was derived from the USGS topographic map. Volume was estimated from a few ground penetrating radar points and area-volume scaling. McDonald's (1995) thesis tracked changes in mass of 
the Collier Glacier as it related to climate. His area changes, estimated from groundbased and aerial photos, were limited to the main trunk. Beedlow (2010) measured the energy balance on Collier Glacier and like McDonald he was only concerned with the main trunk of the glacier. O'Connor et al. (2001) reported on the changes of the 15 named glaciers. The only complete inventory of the glaciers and perennial snowfields was completed by Fountain et al. (2007) summarizing the glacier and perennial snow features found on the 24,000 scale U.S. Geological Survey (USGS) topographic maps, based on photographs taken in 1957 . This thesis will be an attempt to complete a full history of the temporal area and volume changes for the glaciers and perennial snowfields since the end of the LIA on the Three Sisters.

For the purposes of this thesis is important to define the terms glacier, perennial snowfield, and seasonal snowfield. A glacier is defined as a perennial snow or ice body that moves (Cuffey and Paterson, 2011). A perennial snowfield is a stagnate body of snow or ice and seasonal snowfields are not persistent between imagery years. 


\section{Chapter Two - Glacier Inventory}

\section{Introduction}

The purpose of this chapter is to compile glacier and perennial snowfield inventories on the Three Sisters Volcanoes and to test whether the glaciers depictions on the USGS 1:24,000 (24K) scale topographic maps accurately reflect glacier boundaries I observe on the same aerial photographs used to create the $24 \mathrm{~K}$ maps. Glacier and perennial snowfield inventories are necessary to describe their extent and distribution, to assist in providing an estimate of water resources, and offer updated landscape information for recreation and hazard potential. Inventories have been completed elsewhere internationally (Aniya, 1988; Andresassen et al., 2008; DeBeer and Sharp, 2009; Bolch et al., 2010) and in the United States (Nylen, 2001; Granshaw and Fountain, 2006; Basagic and Fountain, 2011; Dick, 2013).

\section{Methods}

To investigate the validity of the $24 \mathrm{~K}$ glacier and perennial snowfield inventory $\mathrm{I}$ obtained shapefiles of the outlines from Fountain et al. (2007) and downloaded USGS maps of the region from 1959 and 1988 from the USGS topo viewer website (http://ngmdb.usgs.gov/maps/TopoView). To construct glacier and perennial snowfield inventories for the Three Sisters I used aerial imagery from 1949, 1957, 1990, and satellite imagery from 2003 (Table 1). Single frame vertical aerial imagery (with greater than 50\% overlap) taken by the United States Geologic Survey (USGS) in 1949 and 1957 and the United States Department of Agriculture (USDA) in 1990 were orthorectified. 
Dr. Jim O'Connor from the Oregon Water Science Center (OWSC) supplied the 1949 and 1990 photographs. The 1957 photographs and $10 \mathrm{~m}$ National Elevation Dataset (NED) digital elevation model (DEM) were downloaded from the USGS Earth Explorer and National Map websites, respectively. The NED DEM was produced from the rasterzation of elevation contours from the USGS 24K topographic maps based on the 1957 imagery (USGS, 2010). The 2003 Quickbird satellite imagery was collected and orthorectified by DigitalGlobe Inc. and supplied by Google Earth.

Table 1. Imagery and digital elevation model (DEM) used to compile the glacier inventories and orthorectification process. Data sources and collectors include the United States Geological Survey (USGS) Oregon Water Science Center (OWSC) Portland, OR, the United States Department of Agriculture (USDA), Google Earth, National Aerial Imagery Program (NAIP), Quantum Spatial Inc. (QSI), Portland, OR, and the Oregon Department of Geology and Mineral Industries (DOGAMI). 'I Year' is year imagery was created and ' $P$ Year' is publication or creation year. Vertical aerial data type are single frame.

\begin{tabular}{|c|c|c|c|c|c|}
\hline I Year & P Year & Data Type & $\begin{array}{c}\text { Data } \\
\text { Collector }\end{array}$ & Source & Use \\
\hline 1949 & 2012 & Vertical Aerial & USGS & OWSC & Inventory \\
\hline 1957 & 2012 & Vertical Aerial & USGS & www.earthexplorer.usgs.gov & Inventory \\
\hline 1957 & 2003 & 10 m NED DEM & USGS & www.nationalmap.gov & Orthorectification \\
\hline 1957 & 1959 & $\begin{array}{c}\text { USGS 1:62,000 } \\
\text { Map }\end{array}$ & USGS & ngmdb.usgs.gov/maps & $\begin{array}{l}\text { Inventory } \\
\text { Validation }\end{array}$ \\
\hline $1979-82$ & 1988 & USGS $1: 24,000$ & USGS & ngmdb.usgs.gov/maps & $\begin{array}{l}\text { Inventory } \\
\text { Validation }\end{array}$ \\
\hline 1990 & 2012 & Vertical Aerial & USDA & OWSC & Partial Inventory \\
\hline 1990 & 2012 & $10 \mathrm{~m}$ DEM & Thesis & Vertical Aerials & Orthorectification \\
\hline 2003 & 2012 & $\begin{array}{l}\text { Satellite } \\
\text { Imagery }\end{array}$ & DigitalGlobe & Google Earth Viewer & Inventory \\
\hline 2005 & 2007 & Orthophotos & NAIP & datagateway.nrcs.usda.gov & Orthorectification \\
\hline 2010 & 2011 & Lidar DEM & QSI & DOGAMI & Orthorectification \\
\hline
\end{tabular}

The 2005 National Aerial Imagery Program (NAIP) orthoimagery were downloaded from the USDA data gateway portal to be used as a guide for orthorectifing single frame aerial imagery. No inventory was generated for this year (2005) because the imagery was taken in July with large amounts of seasonal snow. Finally, I used a light distance 
and range (lidar) DEM (1 $\mathrm{m}$ spatial resolution) produced by Watershed Sciences Inc. (now Quantum Spatial Inc.) in Portland, Oregon for the Oregon Department of Geology and Mineral Industries (DOGAMI). The lidar data were acquired between September $10^{\text {th }}$ and September $12^{\text {th }}, 2010$, with no accompanying aerial photography, resulting in no data collection for glacial boundaries in 2010.

\section{Orthorectification, Mosaicing, and DEM Creation}

The photographs were first georeferenced to rectify surface areas to true planview using ERDAS Imagine's Leica Photogrammetry Suite (LPS) (EOS, 2004). The ground coordinate system referenced was the WGS 1984 UTM zone 10N using the 2005 NAIP orthophotographs and the vertical reference was the $1 \mathrm{~m}$ resolution lidar DEM. To align the imagery relative to the ground surface, control points were selected in what was assumed to be non-changing features (e.g. bedrock outcrops, large boulders). The imagery in 1949, 1957, and 1990 were stereo images from which a $10 \mathrm{~m}$ DEM for each was created using LPS. The stereo images for each year were mosiaced together to a single image file. These DEMs were used to orthorectify the mosaiced aerial imagery.

\section{Digitizing}

Vector polygons outlining snow and ice features were digitized at a 1:2000 scale in ArcGIS and Google Earth. This scale is a compromise between efficacy and outline resolution (Sitts et al., 2010). I used, but was not limited to, the $24 \mathrm{~K}$ scale topographic glacier database as a guide to locate the snow and ice features. I first digitized the 1957 imagery, the same imagery from which the $24 \mathrm{~K}$ map and outlines were produced. Any feature larger than $0.0001 \mathrm{~km}^{2}$ (10 m DEM pixel) was digitized. The 1949 and 1990 
features on the imagery were then digitized using the 1957 polygons as a guide. The final inventory, 2003, was digitized in Google Earth focusing in on features that were found as perennial in the previous inventories. Polygons were attributed with the identification record number (RECNO) from the $24 \mathrm{~K}$ inventory, a new identification system specific to this study, and area. A new identification system was necessary because I identified snow patches that were not included in the $24 \mathrm{~K}$ inventory. Topographic characteristics of elevation, slope, and aspect were calculated for each feature based on the DEMs created.

To determine seasonal versus perennial features, I used rules modified from DeVisser and Fountain (2015).

- Any feature present in the 1949, 1957, 1990, 2003 inventories was considered to be perennial.

- Any feature present in only one inventory was considered to be seasonal and eliminated from the inventory.

- Any feature missing in middle inventories (e.g. found in 1949 missing in 1957 there again in 1990) were considered to be seasonal.

- A feature found in the first two inventories (1949 and 1957) but not in the later ones was considered to be a perennial feature that disappeared.

- Digitized features in 1949 and 1957 were considered seasonal if the following criteria were met; $<0.005 \mathrm{~km}^{2}$ and no landscape modification were visible. Modifications include lateral or terminal moraines and protalus ramparts (Figure 4). 


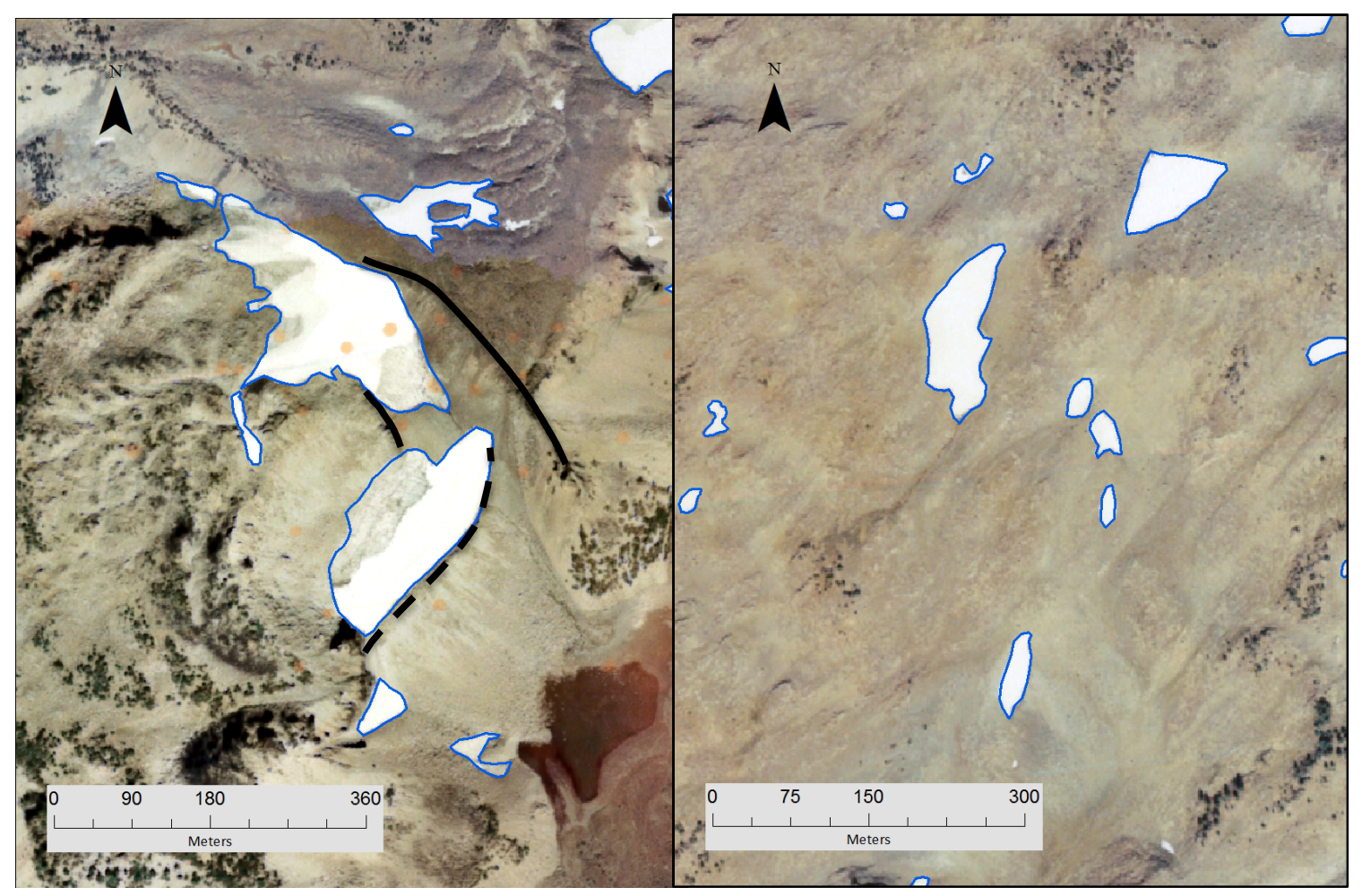

Figure 4. Examples of the presence and lack of landscape modification due to perennial snow or ice. The left image (September 14, 1990) shows perennial features with lateral moraines (solid black lines) and the crest of a protalus rampart (dashed black line) on the southern flank of Middle Sister. The image on the right (September 14, 1990) shows seasonal snow patches on the south west flack of Middle Sister that lack landscape features. Images are in WGS 84 UTM Zone 10.

\section{Uncertainty}

The uncertainty of digitizing polygons was calculated using two methods. For the

features with clear boundaries, such as the larger glaciers, the uncertainty, $U$, is the root sum of squares of positional, P; digitizing, D; and interpretation, I, uncertainty (Sitts et al., 2010).

$$
U=\sqrt{P^{2}+D^{2}+I^{2}}
$$

Positional uncertainty is the horizontal error of the image resulting from

orthorectification to the surface topography. For this study the positional uncertainty is assumed to be zero because a shift in the horizontal position of a polygon will not affect 
the surface area for relatively small features. The digitizing uncertainty is the error induced by attempting to digitize the glacier perimeter. The digitizing uncertainty was calculated using Ghilani (2000),

$$
D=1.414 \sqrt{A} D_{U}
$$

where $\mathrm{A}$ is the area of the glacier in $\mathrm{km}^{2}$ and $D_{U}$ is the linear digitizing uncertainty in $\mathrm{km}$. This approach calculates the uncertainty of a square with an equivalent area to the glacier of interest, regardless of the number of vertices. To determine $D_{u} l$ evaluated ten outlines, chosen at random, and using the measure tool in ArcGIS I calculated the distance between the digitized outline and the actual edge of the glacier determined at a much higher resolution (1:500).

Interpretation uncertainty is the error caused by shadows, debris-covered ice, and seasonal snow patches that mask the glacier edge. The interpretation uncertainty was estimated by defining the areas $\left(\mathrm{km}^{2}\right)$ by drawing polygons in ArcGIS 10.1 on individual features where it could not be determined whether ice was present (Figure 5). 


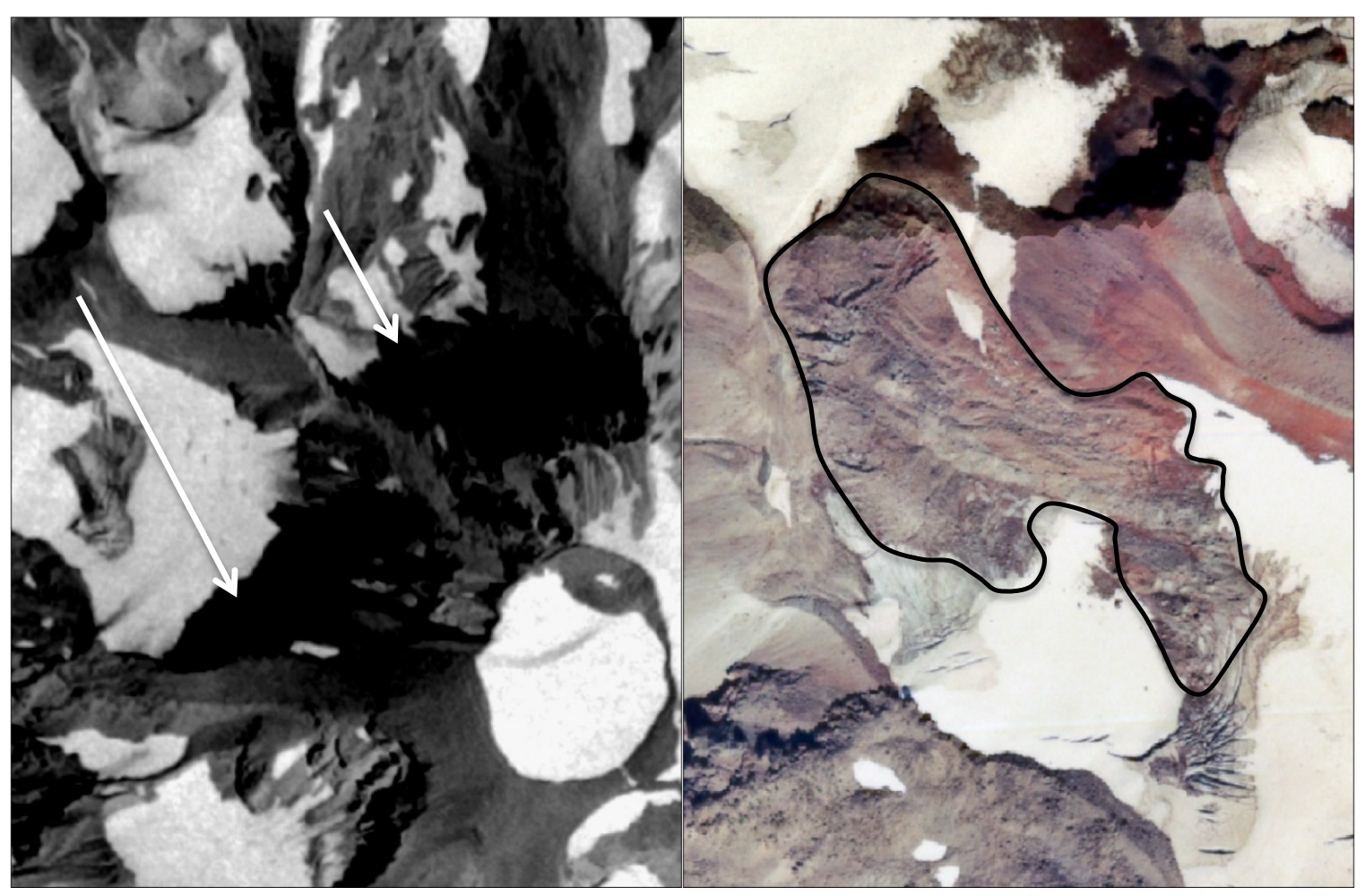

Figure 5. Examples of interpretation uncertainty. Arrows on the left image (September 3, 1957) of the Lost Creek and Skinner glaciers point to glacier zones covered in shadows. The image on the right (September 14, 1990) shows debris covering a glacier (black outline) on the Lost Creek Glacier.

For perennial snow patches a buffer (calculated zone around the defined perennial outline that represents the uncertainty of an outline) was applied to estimate uncertainty (Granshaw and Fountain, 2006). These snow patches can vary in size greatly from year to year making the 'true' edge of the perennial snow unclear. Therefore, a buffer inside of the snow patch provides a more liberal estimate of uncertainty. I applied an inner buffer on the polygons because the true extent of the perennial portion of the snow patch is assumed to be inside of the seasonal snow cover. This reduced the possible size of the features according to the size of buffer applied. 


\section{Results}

Comparison of the 1959 Three Sister Quadrangle, 1:62,500 map, imagery date 1957, to the 1988 North Sister and South Sister Quadrangles, 1:24,000 maps, imagery dates 1979-1981, showed that the glacier outlines, were updated (Figure 6). Searching the USGS Earth Explorer website for aerial imagery I determined that the glacier outlines on the 1988 map were updated using 1980 aerial imagery. These aerial photos were downloaded and after georeferencing the imagery in ArcGIS the $24 \mathrm{~K}$ outlines matched nicely with the features in the imagery. These updates to the glacier outlines however were of variable quality. Some snow and ice feature outlines were accurately updated (e.g. now outlining ice in 1988 when missing in 1957), in other instances they were incorrectly updated (e.g. outline were deleted where ice is present) and overall many smaller snowfields present were added to the 1988 map. The aerial photographs of 1980 used in the 1988 maps were taken in July a time of year that much seasonal snow is still present. Consequently, many of the snow/glacial feature's true boundaries on the 1988 maps are masked by seasonal snow. Due to the missing outlines and the snowy nature of the imagery the $24 \mathrm{~K}$ data were not used as an inventory. The topography for both maps was derived from the 1957 aerial imagery; the 10 m NED DEM of 2003 is based on this imagery. The difference between the two maps was that the glacier outlines had been updated but the topography is the same - another reason to mistrust the $198824 \mathrm{~K}$ maps. 


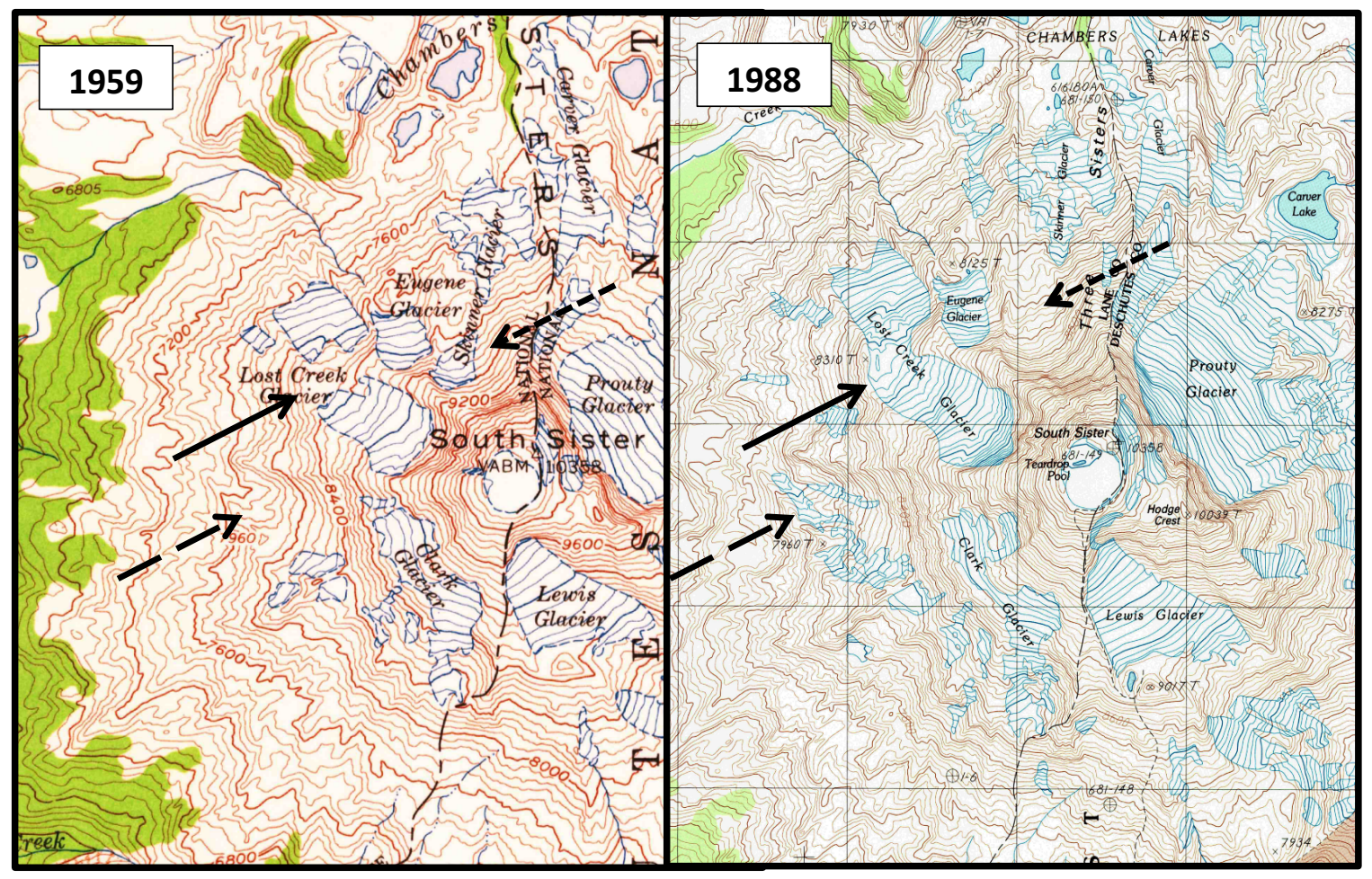

Figure 6. Specific zones on the 1959 1:62,500 scale map, imagery date 1957, (left) and the 1988 1:24,000 scale map imagery date 1957 with limited revision from photos taken in 1979-1982 (lower right) where the glacier outlines have been updated. The solid arrow points to the connection of the Lost Creek Glacier in 1988, the short dashed arrow points to the area on the Skinner Glacier deleted, and the long dashed arrow points to an area where snowfields have been added. Maps are in WGS 84 UTM Zone 10.

The orthorectification and DEM creation for the inventories was completed with quality results for orthorectification and mixed results for DEM creation. The spatial resolution (pixel size) of the orthorectified imagery for 1949 was $2 \mathrm{~m}, 3 \mathrm{~m}$ for 1957, and $1 \mathrm{~m}$ for 1990, respectively. Lower resolution of the 1949 and 1957 imagery was a result of poor initial image quality, smaller image scale (higher flight altitude), and black and white rather than color images. The 1990 images lacked complete coverage of the study area. The 1949 and 1957 mosaiced imagery was orthorectified to the 1957 NED DEM due to the poor quality DEMs created for their respective years. The 1949 and 1957 DEMs were found to not represent surfaces accurately due to the same 
reason for the low resolution of the orthoimagery. Overall, the topography, especially in steeper slopes, was stunted, producing lower than expected elevations. An 8-year difference was determined to be sufficient for orthorectifying the 1949 image to the 1957 NED DEM due to the lack of a quality 1949 DEM. The 1990 mosaiced imagery was orthorectified to the 1990 created DEM.

For larger ice features, of the two sources of uncertainty (digitizing and interpretation) the interpretation typically represented a larger percentage of the total. The digitizing uncertainty was smaller and that was mainly controlled by the area of the feature and the observed Du. A $0.003 \mathrm{~km} \mathrm{D}_{\cup}$ was found for 1949, 1957, and 1990, and $0.001 \mathrm{~km}$ for 2003. Even with lower resolution for the 1949 and 1957 orthophotos the same Du was found for all of the imagery orthorectified in this study. This is likely because of the 1:2000 scale at which the snow and ice features were digitized. If the features were digitized at a smaller scale the Du could be different for the different resolution imagery.

For smaller perennial snow patches a buffer uncertainty was calculated. A different sized buffer was applied for the different imagery dependent on the image resolution, date of imagery, and scale of imagery. A $10 \mathrm{~m}( \pm 5 \mathrm{~m})$ buffer was used for

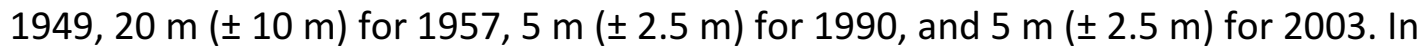
general, the uncertainty showed larger ice features having smaller relative uncertainties as compared to smaller features, which had larger relative uncertainties. This result is not surprising because the buffer method yields larger relative uncertainties for the smaller snow features as compared to the root sum of squares method for larger 
glaciers.

The inventories showed 402 snow and ice features identified in 1949, 402 in 1957, 337 in 1990 (lack of full image coverage), and 122 in 2003. The 1990 inventory was not comprehensive due to incomplete imagery coverage (Figure 7). The 1990 coverage did not include Thayer and Villard glaciers and up to 63 other snow and ice features because according to the rules of perennial versus seasonal snow dates for only 1949 and 1957 do not qualify. The features found in 1949 and 1957 but missing in 1990 due to incomplete coverage were classed as 'no data'. Results showed 122 perennial features present in the 1949, 1957, 1990 (it was assumed that the Thayer and Villard glaciers did not disappear and reform by 2003) inventories, and 121 in 2003 (Table 2). Only one feature disappeared in the 54-year time span from 1949 to 2003 . Of the 122 glaciers and perennial snowfields 72 are located on the edifice of North \& Middle Sisters with a total of $5.12 \pm 1.82 \mathrm{~km}^{2}$ with an average of $0.073 \mathrm{~km}^{2}$; South Sister hosts 52 with a total area of $4.76 \pm 1.66 \mathrm{~km}^{2}$, and an average of $0.092 \mathrm{~km}^{2}$.

As mentioned previously 65 features are not identified in 1990 because of lack of aerial imagery were classified as 'no data' and were not included in any calculations, however some of these features could be perennial. I evaluated these 65 features that were identified in 1949 and 1957 to determine their total area and if they would pass the rules set up for a perennial feature. In 1949 these 65 features totaled $0.41 \pm 0.26$ $\mathrm{km}^{2}\left(4.5 \%\right.$ of perennial total) and $0.28 \pm 0.38 \mathrm{~km}^{2}(2.8 \%)$ in 1957. Of the 65 features 30 would have been counted as seasonal because they are smaller than $0.005 \mathrm{~km}^{2}$ and do not show any signs of landscape modification. It is noted that 35 features could be 
perennial features that are not included into the total population statistics or analysis.

That being said, given the small percentage of area that they represent of the total population their inclusion would not greatly change the population statistics.

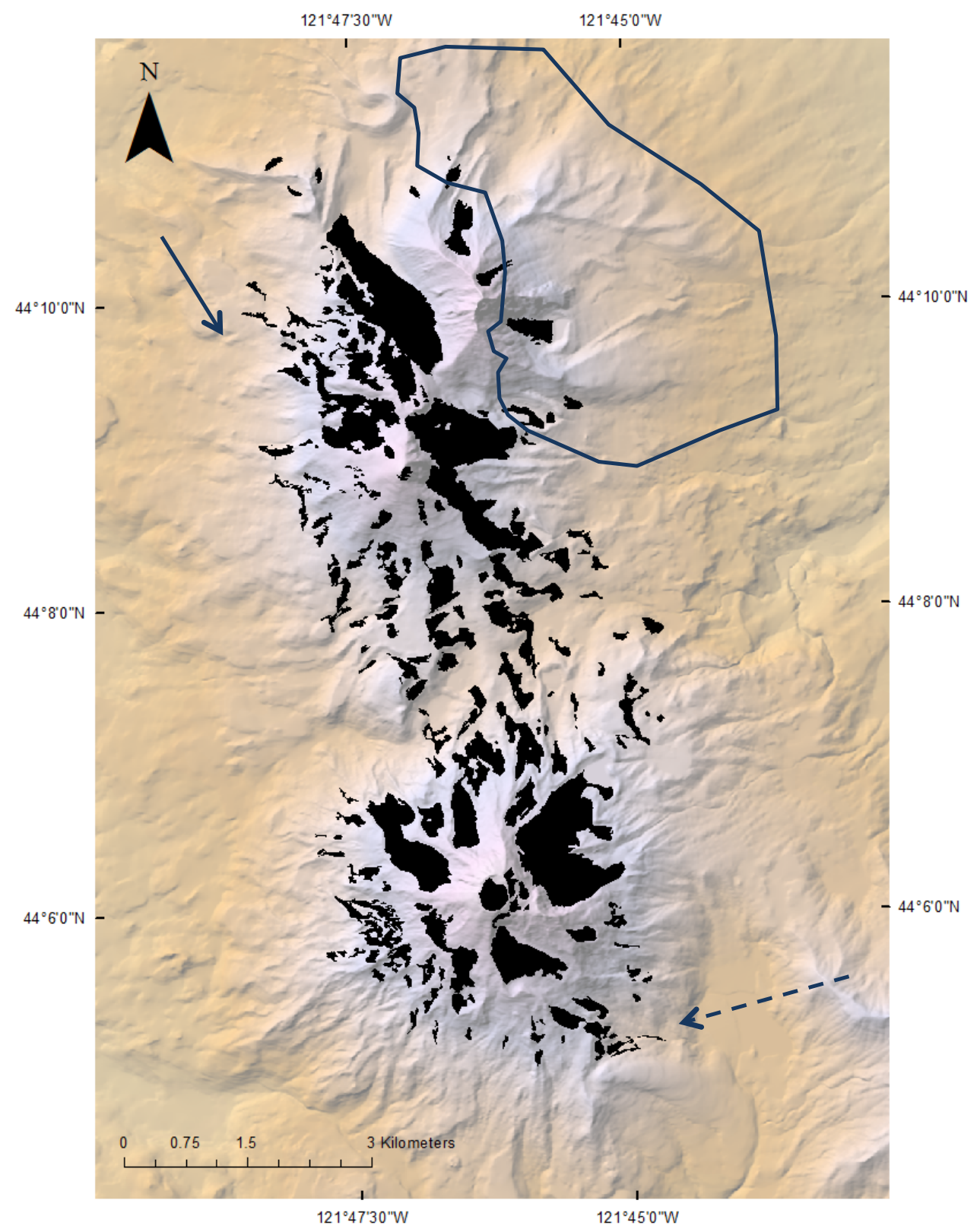

Figure 7. National Elevation Dataset Digital Elevation Model (USGS, 2010) map of the Three Sisters Volcanoes showing the glaciers and perennial snowfields (in black) from the combined outlines from the inventories of $1949,1957,1990$, and 2003 . The blue polygon zone is location of missing aerial photography for 1990. The solid blue arrow points to the perennial snowfield that was lost and the dashed blue arrow points to the largest glacier, Prouty. Map is in WGS 84 UTM Zone 10. 
Table 2. The number of total features, seasonal snowfields, glacier and perennial snowfields, and area statistics for each inventory. In 1949 and 1957 a $0.005 \mathrm{~km}^{2}$ threshold was used as described in the methods.

\begin{tabular}{|c|c|c|c|c|c|c|c|c|}
\hline & \multicolumn{2}{|r|}{1949} & \multicolumn{2}{|r|}{1957} & \multicolumn{2}{|r|}{1990} & \multicolumn{2}{|r|}{2003} \\
\hline & $\mathbf{n}$ & Area $\left(\mathrm{km}^{2}\right)$ & $\mathbf{n}$ & Area $\left(\mathrm{km}^{2}\right)$ & $\mathrm{n}$ & Area $\left(\mathrm{km}^{2}\right)$ & $\mathbf{n}$ & Area $\left(\mathrm{km}^{2}\right)$ \\
\hline Total & 402 & $9.85 \pm 2.38$ & 402 & $10.41 \pm 4.5$ & 337 & $7.48 \pm 0.74$ & - & - \\
\hline Seasonal Total & 215 & $0.41 \pm 0.47$ & 215 & $0.25 \pm 0.64$ & 215 & $0.08 \pm 0.08$ & - & - \\
\hline No Data & 65 & $0.41 \pm 0.26$ & 65 & $0.28 \pm 0.38$ & - & - & - & - \\
\hline Perennial Total & 122 & $9.03 \pm 1.65$ & 122 & $9.88 \pm 3.38$ & 122 & $7.40 \pm 0.66$ & 121 & $7.1 \pm 1.16$ \\
\hline Perennial Mean & & 0.074 & & 0.081 & & 0.059 & & 0.058 \\
\hline Perennial Median & & 0.016 & & 0.017 & & 0.006 & & 0.007 \\
\hline Perennial Maximum & & 1.07 & & 1.23 & & 1.18 & & 1.11 \\
\hline Perennial Minimum & & 0.005 & & 0.005 & & 0.0002 & & 0.0002 \\
\hline
\end{tabular}

The population distributions of each inventory are highly skewed towards smaller features (Figure 8). Between 1949 and 2003 84-89\% of the features were less than $0.1 \mathrm{~km}^{2}$, in $194986 \%$, in $195784 \%$, in $199088 \%$, and in 2003 87\%. Between 1949 and 2003 these small features make up 16-25\% of the total ice-covered area, in 1949 $2.35 \mathrm{~km}^{2}$ (25\%), in $19572.01 \mathrm{~km}^{2}$ (20\%), in $19901.23 \mathrm{~km}^{2}(17 \%)$, and in $20031.11 \mathrm{~km}^{2}$ (16\%). The total area of the perennial features increased from 1949 to $1957(0.85 \pm 3.73$ $\left.\mathrm{km}^{2}, 9.4 \%\right)$, decreased from 1957 to $1990\left(-2.63 \pm 3.34 \mathrm{~km}^{2},-26.6 \%\right)$, and did not significantly change from 1990 to $2003\left(-0.15 \pm 1.32 \mathrm{~km}^{2},-2.1 \%\right)$, with an overall decrease from 1949 to $2003\left(-1.93 \pm 2.02 \mathrm{~km}^{2},-21.3 \%\right)$. The mean size reflects the same pattern. The Prouty Glacier is the largest glacier, $1.072 \pm 0.040 \mathrm{~km}^{2}$ in 1949 enlarged to $1.115 \pm 0.040 \mathrm{~km}^{2}$ in 2003 . 

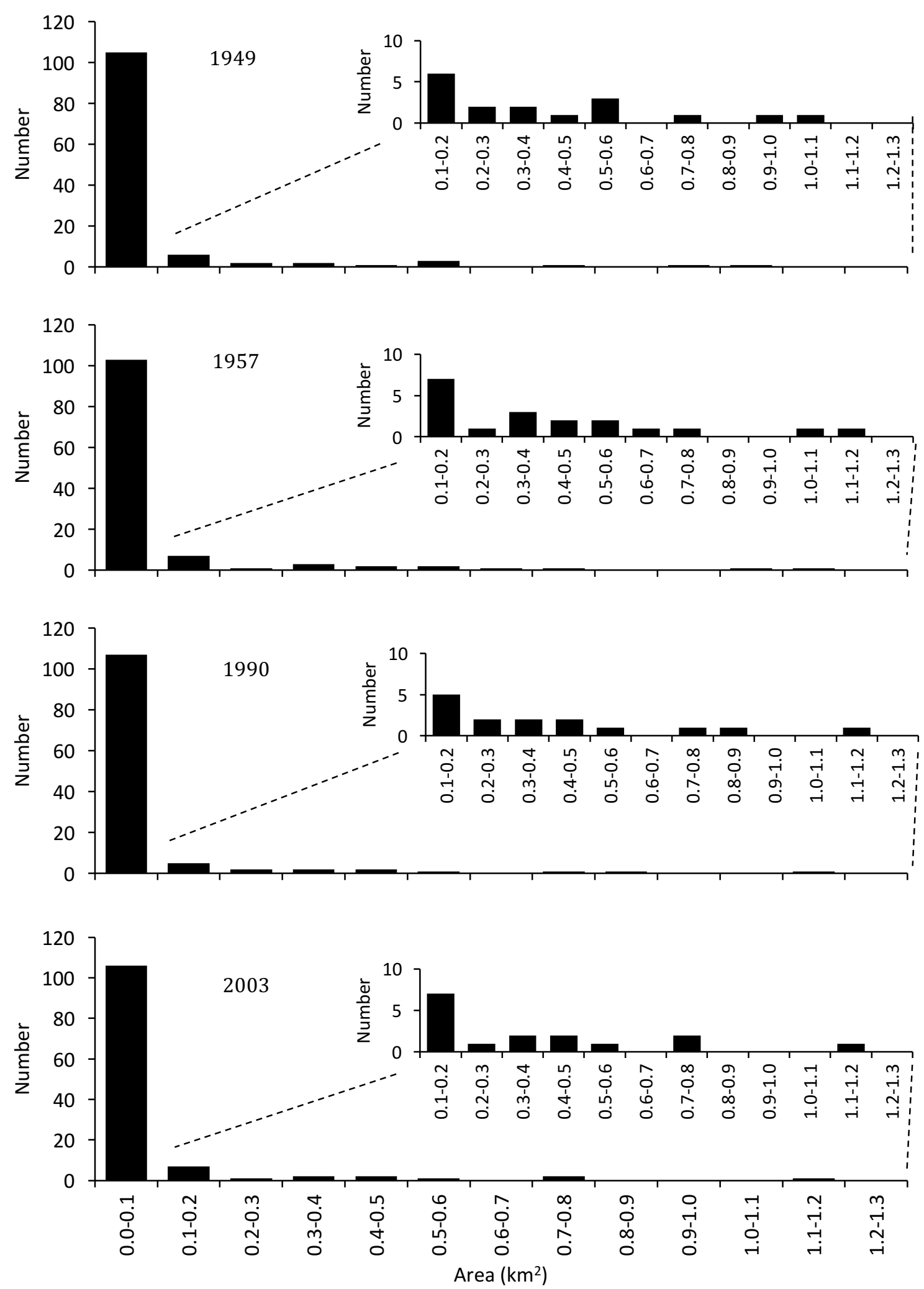

Figure 8. The population distribution of glacier and perennial snowfield area for the inventories. The maximum value for each bin's area range is included in that grouping. Number is number of glaciers and perennial snowfields. 


\section{Analysis}

To characterize the topography of the glaciers and perennial snowfields the topographic statistics were calculated (Figure 9). Based on the USGS NED 10 m DEM of the 1957 surface and the 1957 outlines, the average elevations of each feature ranged from 2080 m to 3112 m with a mean (median) of 2428 m (2365 m). The average elevation of the spatial distribution of perennial snow and ice is $2518 \mathrm{~m}$. Most of the snow and ice covered area, $9.16 \pm 2.82 \mathrm{~km}^{2}$ (92.7\%), was found between $2300 \mathrm{~m}$ and $2800 \mathrm{~m}$ with the most area (26.2\%) occurring between $2400 \mathrm{~m}$ and $2500 \mathrm{~m}$. Lowest ice on the mountains was located at $2075 \mathrm{~m}$ and the highest ice at $3148 \mathrm{~m}$. Mean slopes ranged from $2.9^{\circ}$ to $41.1^{\circ}$ with an average of $20.9^{\circ}$ (and a median of $20.6^{\circ}$ ). The glaciers and perennial snowfields faced all directions, most of the area, $7.98 \pm 2.74 \mathrm{~km}^{2}(80.7 \%)$, faced the NW to E direction.

Based on the created 1990 DEM of the 1990 surface and the 1990 outlines, the average glacier and perennial snowfield elevations ranged from 2069 m to 3123 m with a mean (median) of $2432 \mathrm{~m}(2373 \mathrm{~m})$. For the total snow and ice covered area average elevation is $2548 \mathrm{~m}$ and $6.88 \pm 0.57 \mathrm{~km}^{2}(94.8 \%)$ was found between the elevations of $2300 \mathrm{~m}$ and $2800 \mathrm{~m}$ of which $33.7 \%$ occurs between $2500 \mathrm{~m}$ and $2600 \mathrm{~m}$ (Figure 9). The lowest ice was found at $2045 \mathrm{~m}$ and the highest at $3150 \mathrm{~m}$. Mean slopes range from $3.8^{\circ}$ to $43.4^{\circ}$ with an average of $21.4^{\circ}\left(20.8^{\circ}\right)$ with $6.99 \pm 0.57 \mathrm{~km}^{2}(96.6 \%)$ found between $10^{\circ}$ and $30^{\circ}$. Again the features faced all directions, most of the area, $6.18 \pm$ $0.44 \mathrm{~km}^{2}(85.4 \%)$, falling in the NW to E direction with $5 \%$ more ice facing in that direction compared to 1957. 

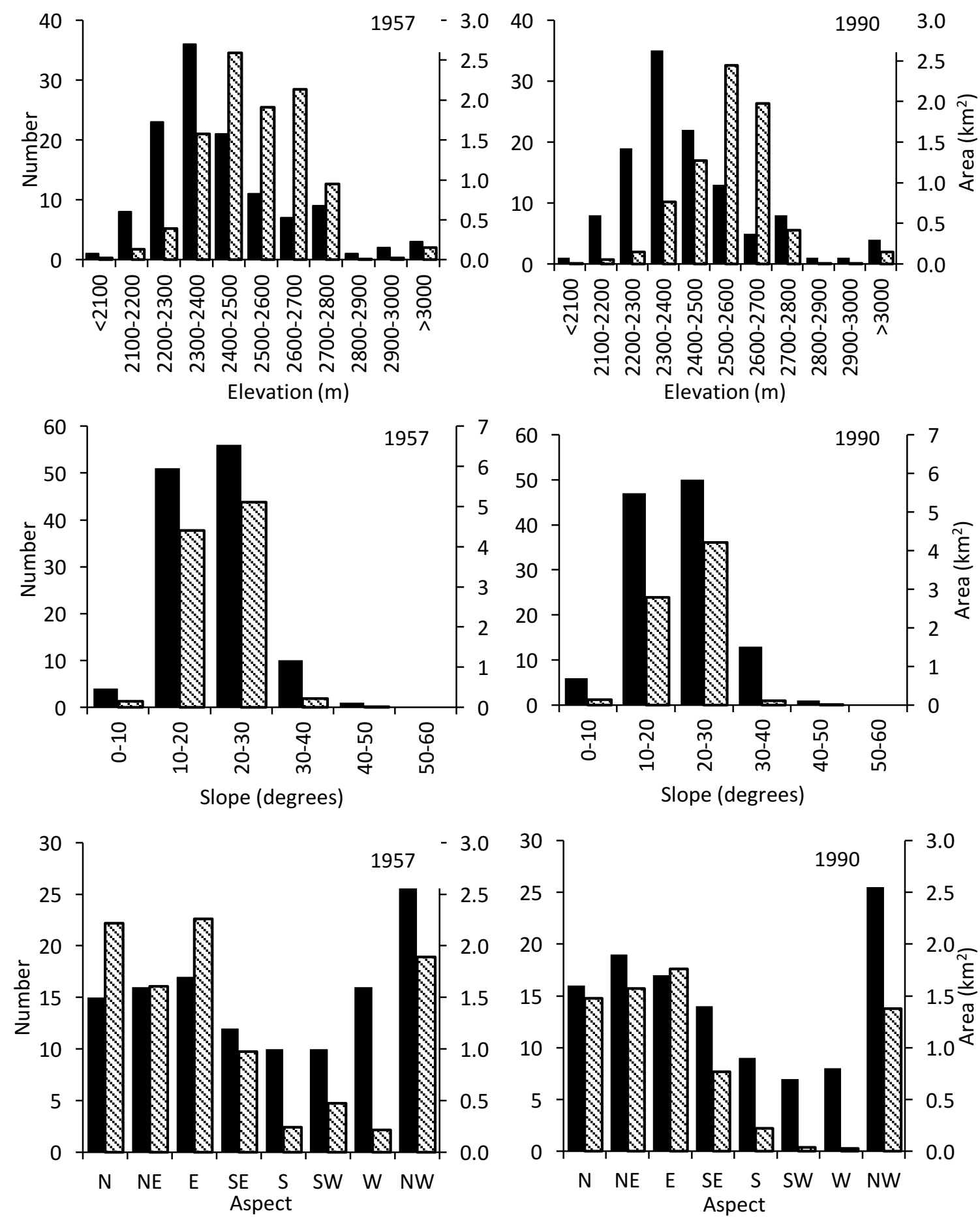

Figure 9. Topographic characteristics of the 1957 (left graphs) and 1990 (right graphs) glacier inventories mean elevation, mean slope, and aspect plotted for number (solid bars) and area $\left(\mathrm{km}^{2}\right)$ (hatched bars). Aspect was grouped into 8 directions $\mathrm{N}=337.5-360$ and $0-22.5, \mathrm{NE}=22.5-67.5, \mathrm{E}=67.5-112.5, \mathrm{SE}=112.5-$ $157.5, S=157.5-202.5, S W=202.5-247.5, W=247.5-292.5, N W=292.5-337.5$. The maximum value for each bin's area range is included in that grouping. 
Glacier and perennial snowfield populations in all inventories were dominated by small features $<0.1 \mathrm{~km}^{2}$, but make up roughly a quarter of the total area with relatively high uncertainties (Figure 10).
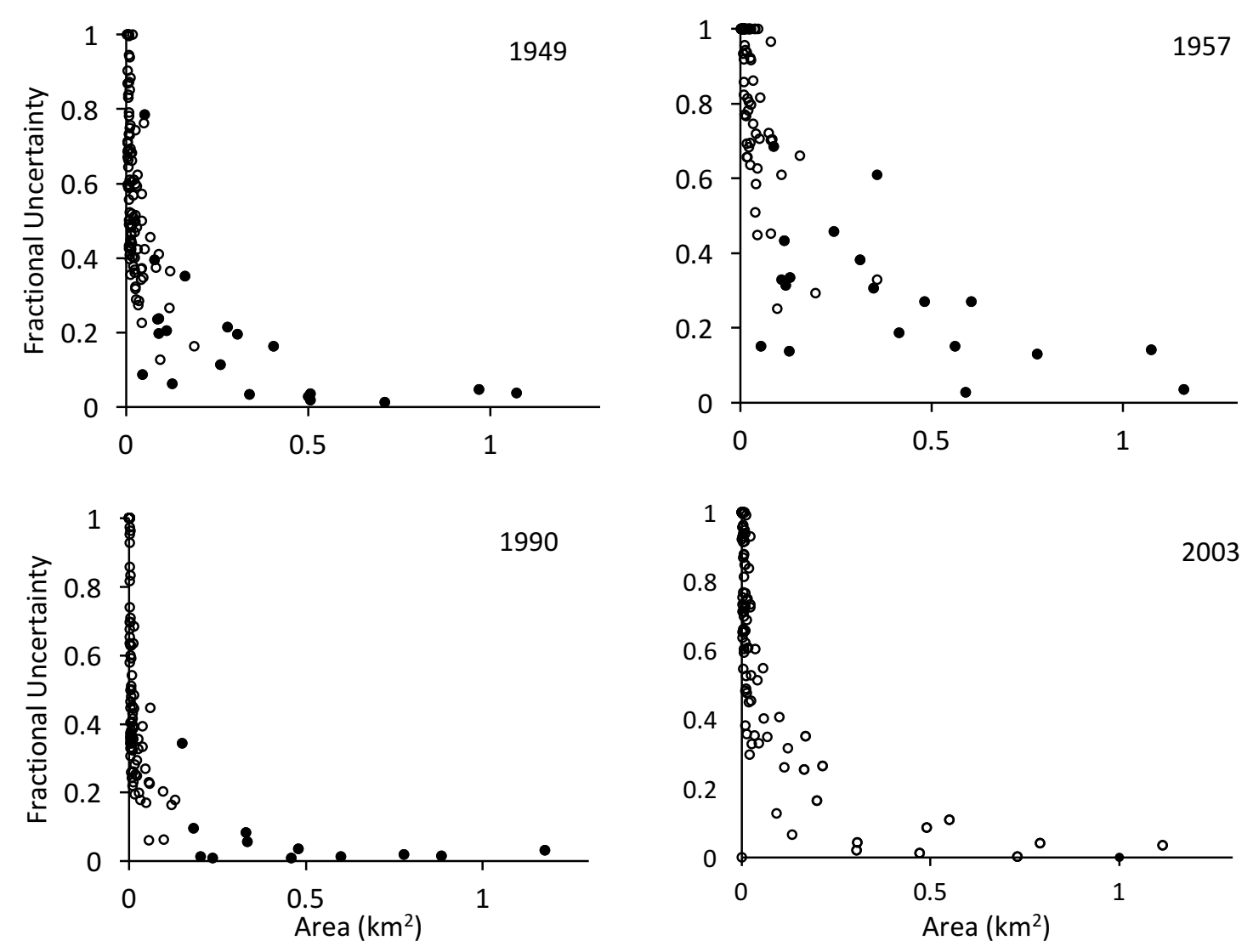

Figure 10. The fractional uncertainty of the glacier and perennial snowfields for the inventories. Open circles are perennial features and solid circles are the 15 named glaciers.

\section{Glaciers versus Perennial Snowfields}

To determine whether the inventories of perennial features are glaciers I used two methods: 1) applying an area threshold and 2) estimating movement. Area thresholds are commonly used as criteria for defining the minimum size for glaciers (Spicer, 1986; Raub et al., 2006; DeBeer and Sharp, 2007; Basagic and Fountain, 2011; Dick, 2013). Using a threshold of $0.1 \mathrm{~km}^{2}$ produces $103\left(2.3 \pm 2.0 \mathrm{~km}^{2}\right)$ perennial 
snowfields and $19\left(7.6 \pm 1.5 \mathrm{~km}^{2}\right)$ glaciers in 1957 (Table 3). By this definition, glaciers account for $78 \%$ of the perennial ice and snow cover. However, if the small $\left(<0.1 \mathrm{~km}^{2}\right)$ features were ignored then an important faction of ice cover would be overlooked. Raub et al. (2006) used an area threshold of $0.05 \mathrm{~km}^{2}$; applying this threshold yields 94 $\left(1.3 \pm 1.5 \mathrm{~km}^{2}\right)$ perennial snowfields and $28\left(8.6 \pm 3.0 \mathrm{~km}^{2}\right)$ glaciers. By this definition, the glaciers account for $87 \%$ of the total perennial snow and ice cover.

Table 3. Comparison of features that are $<0.05 \mathrm{~km}^{2},<0.1 \mathrm{~km}^{2}$, and $>0.1 \mathrm{~km}^{2}$.

\begin{tabular}{lcrcc}
\hline \hline & \multicolumn{2}{c}{1949} & \multicolumn{2}{c}{1957} \\
\cline { 2 - 5 } & Area & \multicolumn{1}{c}{ Count } & Area & Count \\
\hline$<0.05$ & $1.6 \pm 0.83(18 \%)$ & $95(78 \%)$ & $1.3 \pm 1.46(13 \%)$ & $94(77 \%)$ \\
$<0.1$ & $2.4 \pm 1.09(27 \%)$ & $105(86 \%)$ & $2.3 \pm 1.97(23 \%)$ & $103(84 \%)$ \\
$>0.1$ & $6.7 \pm 0.56(73 \%)$ & $17(14 \%)$ & $7.6 \pm 1.50(78 \%)$ & $19(16 \%)$ \\
\hline \multicolumn{5}{c}{$\mathbf{c}$} \\
& & & 2003 & \\
\hline$<0.05$ & $0.7 \pm 0.30(9 \%)$ & $101(83 \%)$ & $0.8 \pm 0.57(11 \%)$ & $102(84 \%)$ \\
$<0.1$ & $1.1 \pm 0.36(15 \%)$ & $105(87 \%)$ & $1.1 \pm 0.66(15 \%)$ & $106(87 \%)$ \\
$>0.1$ & $6.2 \pm 0.27(85 \%)$ & $15(13 \%)$ & $6.0 \pm 0.51(85 \%)$ & $16(13 \%)$ \\
\hline
\end{tabular}

While area thresholds apply an approximate estimate of glaciers versus perennial snow and ice values, the basis is not physical. An alternative approach is to estimate movement - the defining characteristic between glaciers and perennial snow. To determine movement I followed Basagic and Fountain (2011) and estimated whether the critical shear stress exceeds the threshold for movement. If the shear stress at the base of a glacier is greater than $10^{5} \mathrm{~Pa}$ then the glacier deforms or moves. The shear stress is calculated by,

$$
\tau_{b}=\rho_{i} g h \sin \alpha
$$

where $\rho_{i}$ is ice density $\left(900 \mathrm{~kg} \mathrm{~m}^{-3}\right), g$ is gravitational acceleration $\left(9.81 \mathrm{~ms}^{-2}\right), \mathrm{h}$ is ice 
thickness $(\mathrm{m})$, and $\alpha$ is the ice surface slope. I used the maximum slope found in the glacier polygon, providing a conservative estimate (Basagic, 2008; Dick, 2013). The thicknesses were calculated using a scaling relationship for area- volume (Chen and Ohmura, 1990; Bahr et al., 1997) and dividing by the surface area, the thickness was calculated by,

$$
h=\alpha A^{\beta-1},
$$

where $\alpha$ and $\beta$ are empirical constants and $\mathrm{A}$ is the glacier area $\left(\mathrm{km}^{2}\right)$. I used the 'Cascade, small glaciers' scaling factors with an $\alpha$ of 21.346 and a $\beta$ of 1.145 from Chen and Ohmura (1990). Using the 1990 DEM because it was close in time to Driedger and Kennard (1986) the calculated thicknesses matched well with their measured thicknesses (Table 4).

Table 4. The comparison of my estimated average thicknesses in 1990 (shear stress) to the calculated thicknesses by Driedger and Kennard (1986) for the Collier, Prouty, Hayden, and Diller glaciers.

\begin{tabular}{ccc}
\hline \hline Glacier & $\begin{array}{c}\text { Shear Stress } \\
\text { Thickness }(\mathbf{m})\end{array}$ & $\begin{array}{c}\text { Driedger and Kennard } \\
\text { Thickness }(\mathbf{m})\end{array}$ \\
\hline Collier & 21 & 19 \\
Prouty & 22 & 17 \\
Hayden & 21 & 26 \\
Diller & 20 & 20 \\
\hline
\end{tabular}

Of the 122 glacier and perennials snowfields in the 1957 inventory 19 (16\%) exceeded the critical stress, with a total area of $7.76 \pm 1.50 \mathrm{~km}^{2}(79 \%)$ and a mean of $0.395 \mathrm{~km}^{2}$. By 1990 the number of glaciers drops to $9(7 \%)$, with a total of $5.21 \pm 0.209$ $\mathrm{km}^{2}(79 \%)$ and a mean of $0.484 \mathrm{~km}^{2}$ (Table 5). I applied the 19 glaciers dataset found in 1957 to 1949 and derived the sizes in 1949 and applied 9 glacier dataset from 1990 to 2003. I did not calculate shear stress for 1949 or 2003 because I didn't have DEMs for 
their years.

Table 5. Comparison of the total glacier and perennial snowfield statistics and glaciers determined by the basal shear stress threshold. Those features determined to be glaciers in 1957 and 1990 were considered to be glaciers in 1949 and 2003 respectively. Max is maximum and min in minimum. Area is $\mathrm{km}^{2}$.

\begin{tabular}{|c|c|c|c|c|}
\hline \multirow[b]{2}{*}{ Statistic } & \multicolumn{2}{|c|}{1949} & \multicolumn{2}{|c|}{1957} \\
\hline & Total & $>10^{5} \mathrm{~Pa}$ & Total & $>10^{5} \mathrm{~Pa}$ \\
\hline Number & 122 & 19 & 122 & 19 \\
\hline Mean Area & 0.072 & 0.351 & 0.091 & 0.408 \\
\hline Median Area & 0.021 & 0.279 & 0.023 & 0.347 \\
\hline Max Area & 1.07 & 1.07 & 1.16 & 1.16 \\
\hline Min Area & 0.005 & 0.045 & 0.005 & 0.05 \\
\hline \multirow[t]{3}{*}{ Total Area } & $9.03 \pm 1.65$ & $6.67 \pm 0.56$ & $9.88 \pm 3.47$ & $7.76 \pm 1.50$ \\
\hline & \multicolumn{2}{|c|}{1990} & \multicolumn{2}{|c|}{2003} \\
\hline & Total & $>10^{5} \mathrm{~Pa}$ & Total & $>10^{5} \mathrm{~Pa}$ \\
\hline Number & 122 & 12 & 121 & 12 \\
\hline Mean Area & 0.064 & 0.484 & 0.060 & 0.311 \\
\hline Median Area & 0.007 & 0.33 & 0.008 & 0.4 \\
\hline Max Area & 1.18 & 1.18 & 1.11 & 1.11 \\
\hline Min Area & 0.0002 & 0.15 & 0.0002 & 0.16 \\
\hline Total Area & $7.40 \pm 0.66$ & $5.81 \pm 0.21$ & $7.10 \pm 1.16$ & $5.51 \pm 0.39$ \\
\hline
\end{tabular}

The number of glaciers are comparable to the results in 1957 using the area threshold of $>0.1 \mathrm{~km}^{2}$ (Table 6). The difference in area between the glaciers that exceeded the threshold is often less than the uncertainty within each threshold. For the Three Sisters the two methods are roughly equivalent. The area of glaciers estimated by the shear stress is within $25 \%$ of the area estimated by the area threshold. Note that the difference increases with time. 
Table 6. Comparison of the glacier area thresholds $\left(0.05\right.$ and $\left.0.1 \mathrm{~km}^{2}\right)$ to the shear stress threshold $\left(>10^{5}\right.$ $\mathrm{Pa}$ ) for a glacier. Those features determined to be glaciers in 1957 and 1990 were considered to be glaciers in 1949 and 2003 respectively. Difference and percentage is for $>0.1 \mathrm{~km}^{2}$ and $>10^{5}$. Area is in $\mathrm{km}^{2}$.

\begin{tabular}{|c|c|c|c|c|}
\hline & \multicolumn{2}{|l|}{1949} & \multicolumn{2}{|c|}{1957} \\
\hline & Area & Count & Area & Count \\
\hline$>0.05 \mathrm{~km}^{2}$ & $7.43 \pm 0.82$ & 27 & $8.58 \pm 2.01$ & 28 \\
\hline$>0.1 \mathrm{~km}^{2}$ & $6.68 \pm 0.63$ & 17 & $7.61 \pm 1.93$ & 19 \\
\hline$>10^{5} \mathrm{~Pa}$ & $6.67 \pm 0.56$ & 19 & $7.76 \pm 1.50$ & 19 \\
\hline Difference & 0.01 & 2 & 0.15 & 0 \\
\hline \multirow[t]{3}{*}{ Percent } & $0.01 \%$ & $11 \%$ & $2 \%$ & $0 \%$ \\
\hline & \multicolumn{2}{|l|}{1990} & \multicolumn{2}{|c|}{2003} \\
\hline & Area & Count & Area & Count \\
\hline$>0.05 \mathrm{~km}^{2}$ & $6.70 \pm 0.36$ & 21 & $6.30 \pm 0.57$ & 19 \\
\hline$>0.1 \mathrm{~km}^{2}$ & $6.16 \pm 0.28$ & 15 & $5.98 \pm 0.51$ & 16 \\
\hline$>10^{5} \mathrm{~Pa}$ & $5.21 \pm 0.21$ & 9 & $4.96 \pm 0.39$ & 9 \\
\hline Difference & 0.95 & 6 & 1.32 & 7 \\
\hline Percent & $15 \%$ & $40 \%$ & $22 \%$ & $44 \%$ \\
\hline
\end{tabular}

In 1957, each method selected 19 glaciers (21 total glaciers), but they were different glaciers and as a result the areas are not identical (Figure 11, Table 7). Using the shear stress all 15 named glaciers exceeded the threshold, using the area threshold all but one named glacier (Villard) were included. Of these five unnamed glaciers that passed the area threshold, three also passed the shear stress threshold. In 1990, only 9 glaciers (9 named) passed the shear stress threshold (they also exceeded the threshold in 1957); the Carver, Clark, Eugene, Irving, Linn, Thayer, and Villard glaciers did not pass. For the area threshold 13 named glaciers passed, Villard and Eugene glaciers did not. 


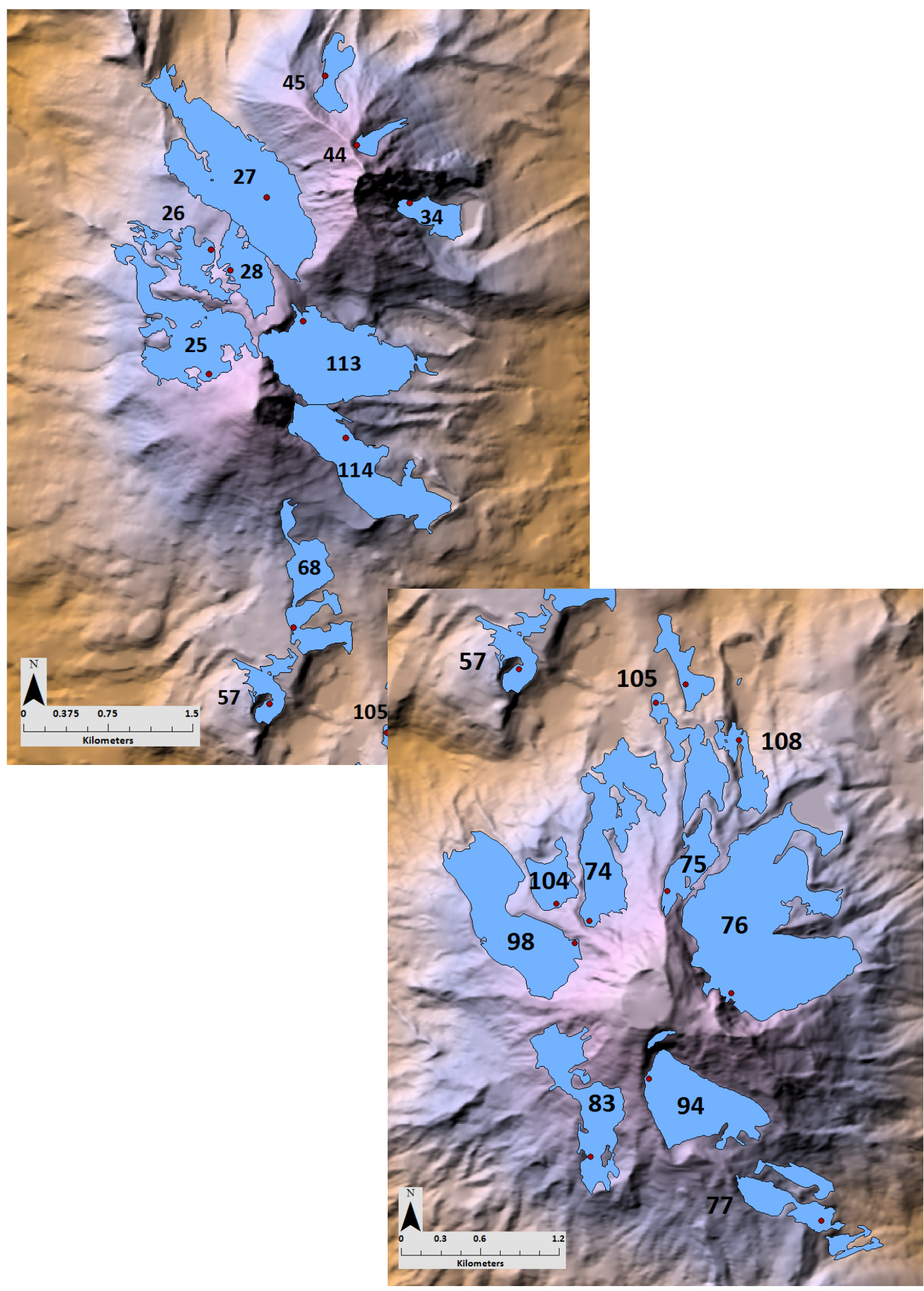

Figure 11. The location of the 21 glaciers identified by either the sheer stress or area threshold with corresponding TS_ID. Red dots are locations of cells with the maximum slope used in basal shear stress calculation. Maps are in WGS 84 UTM Zone 10. 
Table 7. Glaciers that passed the area threshold $\left(0.1 \mathrm{~km}^{2}\right)$ and/or the basal shear stress threshold. RECNO is record number for 24K inventory and TS_ID is identification number from this study.

\begin{tabular}{|c|c|c|c|c|c|c|}
\hline \multirow[b]{2}{*}{ Glacier Name } & \multirow[b]{2}{*}{ RECNO } & \multirow[b]{2}{*}{ TS_ID } & \multicolumn{2}{|c|}{1957} & \multicolumn{2}{|c|}{1990} \\
\hline & & & Area Threshold & $\begin{array}{c}>10^{5} \mathrm{~Pa} \\
\text { Threshold }\end{array}$ & Area Threshold & $\begin{array}{c}>10^{5} \mathrm{~Pa} \\
\text { Threshold }\end{array}$ \\
\hline Collier & 4209 & 27 & $x$ & $x$ & $x$ & $x$ \\
\hline Linn & 4228 & 45 & $x$ & $x$ & $x$ & \\
\hline Thayer & 4216 & 34 & $x$ & $x$ & $x$ & \\
\hline Villard & 4227 & 44 & & $x$ & & \\
\hline Diller & 10525 & 114 & $x$ & $x$ & $x$ & $x$ \\
\hline Hayden & 10518 & 113 & $x$ & $x$ & $x$ & $x$ \\
\hline Irving & 4262 & 68 & $x$ & $x$ & $x$ & \\
\hline Renfrew & 4207 & 25 & $x$ & $x$ & $x$ & $x$ \\
\hline Carver & 4306 & 105 & $x$ & $\mathrm{X}$ & $x$ & \\
\hline Clark & 4281 & 83 & $x$ & $x$ & $x$ & \\
\hline Eugene & 4304 & 104 & $x$ & $x$ & & \\
\hline Lewis & 4293 & 94 & $x$ & $x$ & $x$ & $x$ \\
\hline Lost Creek & 4297 & 98 & $x$ & $x$ & $x$ & $x$ \\
\hline Prouty & 4272 & 76 & $x$ & $x$ & $x$ & $x$ \\
\hline Skinner & 4270 & 74 & $x$ & $x$ & $x$ & $x$ \\
\hline Unnamed & 4208 & 26 & $x$ & & $x$ & \\
\hline Unnamed & 4209 & 28 & $x$ & & $x$ & $x$ \\
\hline Unnamed & 4250 & 57 & $x$ & $x$ & & \\
\hline Unnamed & 4271 & 75 & $x$ & $x$ & & \\
\hline Unnamed & 4273 & 77 & $x$ & $x$ & & \\
\hline Unnamed & 4309 & 108 & & $x$ & & \\
\hline
\end{tabular}

\section{Discussion and Conclusions}

Multiple inventories of the glaciers and perennial snowfields were compiled from orthorectified vertical aerial imagery from 1949, 1957, 1990, and satellite imagery from 2003. Overall, greater uncertainty was found for 1949 and 1957 imagery because of greater seasonal snow cover, lower image resolution, and smaller image scale. Of the two sources of uncertainty for larger glaciers and perennial snowfields (digitizing and interpretation) the interpretation typically represented the larger fraction. The digitizing uncertainty was smaller for larger ice features and that was mainly controlled by the area of the feature and the observed digitizing uncertainty (Du). Smaller 
perennial snow patches always had higher relative uncertainties using the buffer method compared to larger glaciers using the root sum of squares. These results are consistent with other inventories in North America. Basagic (2008) and Dick (2013) found that uncertainties for small features were larger relative to larger features in their studies of the Sierra Nevada and North Cascades, respectively. DeBeer and Sharp (2007) also found the same result for features in the Canadian Cordillera.

The 24K outlines were based on 1957 imagery used for the 1959 1:62,500 USGS topographic map and updated using 1980 imagery for the 1988 USGS map. However, the 1980 imagery shows large amounts of seasonal snow and as a result, the $24 \mathrm{~K}$ inventory was not used. This result differed from other regional inventories that found the $24 \mathrm{~K}$ inventory to be useful (Granshaw and Fountain, 2006; Basagic and Fountain, 2011; Dick, 2013).

The inventories in 1949 and 1957 showed 402 snow and ice features; 1990 showed 337 features. In 199065 features were missing due to insignificant coverage in imagery. In 2003121 features were found as a result of focusing on features that were found as perennial in the previous inventories. The number of perennial features was 122 for 1949 through 1990 and dropped to 121 in 2003 . The total area of the glaciers and perennial snowfields shrank from $9.03 \pm 165 \mathrm{~km}^{2}$ to $7.10 \pm 1.16 \mathrm{~km}^{2}$ in 2003 . Average feature size shrank from $0.072 \mathrm{~km}^{2}$ to $0.060 \mathrm{~km}^{2}$. Of the 65 features that were missing due to insignificant coverage in the 1990 imagery 30 would be considered seasonal snow, and the area total represents a small percentage of the total population area. Comparing the number and area of glaciers and perennial snowfields in 2003 
$\left(121,7.1 \pm 1.16 \mathrm{~km}^{2}\right)$ to previous studies reveals a smaller population and area compared to the Sierra Nevada $\left(1719,39.15 \pm 7.52 \mathrm{~km}^{2}\right)$ (Basagic and Fountain, 2011) and North Cascades $\left(1935,236.20 \pm 12.60 \mathrm{~km}^{2}\right)$ (Dick, 2013). This is to be expected because those studies covered a much larger land area. The number and area of glaciers on the Three Sisters $(19,7.76 \pm 1.50$ in 1957) as compared to other Cascade volcanoes, Mount Hood $\left(12,7.79 \pm 0.33 \mathrm{~km}^{2}\right.$ in 1946) (Jackson, 2007), Mount Rainier $\left(26,88.11 \pm 0.99 \mathrm{~km}^{2}\right.$ in 1971) (Nylen, 2001), Mount Adams (12, $21.73 \pm 0.99 \mathrm{~km}^{2}$ in 1969) (Sitts et al., 2010), and Mount Baker (6, $21.52 \pm 0.711 \mathrm{~km}^{2}$ in 1956) (Dick, 2013), is mostly greater in number and smaller in area with a couple of exceptions.

The average elevation (median) of the glacier and perennial snowfield increased from 1957 to 1990, from $2428 \mathrm{~m}(2365 \mathrm{~m})$ to $2432 \mathrm{~m}$ (2373 m) with most ice-covered area being found between 2300 and $2800 \mathrm{~m}\left(9.15 \mathrm{~km}^{2}(92.7 \%)\right.$ in 1957 and $6.88 \mathrm{~km}^{2}$ (94.8\%) in 1990). The mean feature elevation is lower than those in the Sierra Nevada (3419 m) (Basagic and Fountain, 2011) and higher than those in the North Cascades (1948 m) (Dick, 2013). The elevation band with the greatest ice-covered area also rose from over the same period, from $2400-2500 \mathrm{~m}$ (26.2\%) in 1957 to $2500-2600 \mathrm{~m}$ (33.7\%) in 1990. For comparison, in 1957 the elevation band of $2500-2600 \mathrm{~m}$ was $19.3 \%$ and in $19902400-2500 \mathrm{~m}$ was $17.5 \%$. Glaciers were found facing all directions in both 1957 and 1990, but a greater percentage was found facing the NW-E directions in 1990 (85.4\%) as compared to 1957 (80.7\%). This suggests the bulk of glacier cover on the Three Sisters is becoming concentrated higher up as lower elevations snow and ice is being lost more towards the northerly directions. Mean slope of the glaciers showed no 
significant change $20.9^{\circ}$ in 1957 and $21.4^{\circ}$ in 1990 , with roughly 90\% ranging from $10-$ $30^{\circ}$. The average slopes for the glaciers and perennial snowfields are lower than compared to both the Sierra Nevada $\left(28^{\circ}\right)$ and North Cascades $\left(29.7^{\circ}\right)$. All of these results are similar to results found across the American West.

Distinguishing of glaciers from snowfields used a threshold on area $\left(0.1 \mathrm{~km}^{2}\right)$ and on shear stress. The area threshold of $0.1 \mathrm{~km}^{2}$ (which was determined to be a better estimate than a threshold of $0.05 \mathrm{~km}$ ) and shear stress test yielded 19 glaciers in 1957 and yielded the same number of glaciers, with only two differences. In 1990, 15 glaciers were over for the area threshold and the shear stress test yielded 9 glaciers. Based on these results, an area threshold of $>0.1 \mathrm{~km}^{2}$ criteria seems to be a reasonable for determining a glacier on the Three Sisters when topographic information is absent. These results seem in line with other inventories across the American West. Basagic (2008) found that perennial snow and ice features $>0.15 \mathrm{~km}^{2}$ in the Sierra Nevada of Central California all met the glacier definition. Dick (2013) found that an area threshold of $0.1 \mathrm{~km}^{2}$ in the North Cascades of Northern Washington produced similar results to the glacier definition. She also found that when reducing the shear stress threshold down to $0.925 \times 10^{5} \mathrm{~Pa}$, it matched well with previous inventories. She concluded that a shear stress threshold was a better estimate of identifying glaciers. 


\section{Chapter Three - Temporal Area Change}

\section{Introduction}

The purpose of this chapter is to examine the temporal change of the glaciers and perennial snowfields on the Three Sisters. In addition to the inventories of chapter 2, I used aerial photography, digital elevations models (DEMs), satellite imagery, oblique ground based photography, and previous studies to reconstruct past changes of individual glacier and perennial snowfields. These data were used to quantify both the magnitude and rate of area change.

\section{Methods}

Glacier and perennial snowfield areas were compared between 5 sets of glacier inventories, (1949-1957, 1949-1990, 1957-1990, 1949-2003, and 1990-2003), summarized in chapter 2. I then focus on the 15 named glaciers (the Carver, Clark, Eugene, Lewis, Lost Creek, Prouty, and Skinner glaciers on South Sister and the Collier, Diller, Hayden, Irving, Linn, Renfrew, Thayer, and Villard glaciers on the North and Middle Sisters) to study because they represent most of the ice on the volcanoes, and they have the most extensive historic record (Table 8). The uncertainty for the change in area is estimated from the root sum of squares of the glacier's uncertainties at each time,

$$
U_{T}=\sqrt{\left(U_{1}\right)^{2}+\left(U_{2}\right)^{2}}
$$

where $U_{1}$ and $U_{2}$ are the uncertainties of the glacier area at inventory time 1 and inventory time 2 . The relative uncertainty of the area change is, 


$$
U_{R}=\frac{U_{T}}{A_{1}}
$$

where $A_{1}$ is the area of the initial glacier. If $U_{R}$ is $>1$ the area change was not significant.

Table 8. Imagery and previous studies used in this study for examining the 15 named glaciers.

\begin{tabular}{cccc}
\hline \hline Year & Data Type & Data Collector(s) & Source \\
\hline$\sim 1900$ & Area & Dr. Jim O'Connor & O'Connor et al., 2001 \\
1925 & Area & $\begin{array}{c}\text { Dr. Edwin Hodge } \\
\text { Charlie Cannon and } \\
\text { Jessica Leonard }\end{array}$ & Hodge, 1925 \\
1937 & Area & USGS & USGS - OWSC \\
1949 & Single Frame Vertical Aerial & USGS & www.earthexplorer.usgs.gov \\
1957 & Single Frame Vertical Aerial & USDA & OWSC \\
1990 & Single Frame Vertical Aerial & DigitalGlobe & Google Earth \\
2003 & Satellite Imagery (QuickBird) & Charlie Cannon and & Cannon et al., unpublished \\
2007 & Area & Jessica Leonard &
\end{tabular}

\section{Results and Analysis}

\section{Glacier Inventories}

To examine change in the glaciers and perennial snowfields I summed the area within four different categories: 1) $\left.\left.\geq 0.1 \mathrm{~km}^{2}, 2\right) \leq 0.1 \mathrm{~km}^{2}, 3\right)$ significant change $\left(U_{R}<1\right)$, and 4) insignificant change (Table 9). I used $0.1 \mathrm{~km}^{2}$ instead of the shear stress threshold because I did not calculate values for 1947 and 2003; the number of glaciers is estimated from the 1957 and 1990 as baselines, respectively. Most glacier and perennial snowfields showed more significant change over longer time periods compared to shorter time periods. Shorter time periods show a greater number of features with insignificant change, 63 (52\%) in 1949-1957, 53 (43\%) in 1990-2003, and 65 (53\%) in 1957-1990, compared to longer time intervals, 11 (9\%) in 1949-1990, and 16 
(13\%) in 1949-2003. Smaller features, $<0.1 \mathrm{~km}^{2}$, make up a larger proportion of the insignificant features. From this point forward I will only discuss glaciers and perennial snowfields that exhibit significant change.

Table 9. Area change based on inventory glaciers on the Three Sisters. 1990 has two glaciers with no data, Thayer and Villard glaciers. Significant change is where $U_{R}<1$ and insignificant change are $U_{R}>1$.

\begin{tabular}{|c|c|c|c|c|}
\hline \multirow{2}{*}{$\begin{array}{c}\text { Temporal Period } \\
1949-2003\end{array}$} & \multirow{2}{*}{$\frac{\text { Number }}{122}$} & \multicolumn{2}{|c|}{ Area $\left(\mathrm{km}^{2}\right)$} & \multirow[t]{2}{*}{ Area Change $\left(\mathrm{km}^{2}\right)$} \\
\hline & & 1949 & 2003 & \\
\hline Area $\geq 0.1 \mathrm{~km}^{2}$ & 17 & $6.676 \pm 0.555$ & $6.017 \pm 0.532$ & $-0.659 \pm 0.401$ \\
\hline Area $<0.1 \mathrm{~km}^{2}$ & 105 & $2.351 \pm 1.090$ & $1.070 \pm 1.070$ & $-1.281 \pm 0.648$ \\
\hline Significant Change & 106 & $8.910 \pm 1.526$ & $6.995 \pm 1.082$ & $-1.914 \pm 0.974$ \\
\hline Insignificant Change & 16 & & & \\
\hline 1949-1957 & 122 & 1949 & 1957 & \\
\hline Area $\geq 0.1 \mathrm{~km}^{2}$ & 17 & $6.676 \pm 0.555$ & $7.611 \pm 1.505$ & $0.935 \pm 0.816$ \\
\hline Area $<0.1 \mathrm{~km}^{2}$ & 105 & $2.351 \pm 1.090$ & $2.272 \pm 1.968$ & $-0.079 \pm 1.132$ \\
\hline Significant Change & 59 & $8.174 \pm 1.067$ & $10.44 \pm 2.980$ & $0.832 \pm 1.345$ \\
\hline Insignificant Change & 63 & & & \\
\hline 1949-1990 & 122 & 1949 & 1990 & \\
\hline Area $\geq 0.1 \mathrm{~km}^{2}$ & 18 & $6.565 \pm 0.533$ & $6.200 \pm 0.284$ & $-0.365 \pm 0.332$ \\
\hline Area $<0.1 \mathrm{~km}^{2}$ & 104 & $2.306 \pm 1.086$ & $1.053 \pm 0.343$ & $-1.253 \pm 0.579$ \\
\hline Significant Change & 111 & $8.789 \pm 1.527$ & $7.215 \pm 0.600$ & $-1.575 \pm 0.853$ \\
\hline Insignificant Change & 11 & & & \\
\hline 1957-1990 & 122 & 1957 & 1990 & \\
\hline Area $\geq 0.1 \mathrm{~km}^{2}$ & 19 & $7.865 \pm 1.597$ & $6.328 \pm 0.315$ & $-1.408 \pm 0.809$ \\
\hline Area $<0.1 \mathrm{~km}^{2}$ & 103 & $2.018 \pm 1.876$ & $0.925 \pm 0.312$ & $-1.039 \pm 0.949$ \\
\hline Significant Change & 57 & $9.052 \pm 2.457$ & $6.970 \pm 0.283$ & $-2.081 \pm 1.269$ \\
\hline Insignificant Change & 65 & & & \\
\hline $1990-2003$ & 121 & 1990 & 2003 & \\
\hline Area $\geq 0.1 \mathrm{~km}^{2}$ & 16 & $6.155 \pm 0.272$ & $5.979 \pm 0.509$ & $-0.290 \pm 0.299$ \\
\hline Area $<0.1 \mathrm{~km}^{2}$ & 105 & $1.098 \pm 0.355$ & $1.107 \pm 0.656$ & $-0.012 \pm 0.374$ \\
\hline Significant Change & 67 & $7.101 \pm 0.524$ & $6.717 \pm 0.904$ & $-0.384 \pm 0.548$ \\
\hline Insignificant Change & 54 & & & \\
\hline
\end{tabular}

To examine the effects of time intervals on whether change was significant I grouped the magnitude of change. The distribution clearly shows that over longer time period's area change is skewed towards greater loss and shorter time periods change is smaller (Table 10). For the short time interval of 1949-1957 the bin with the largest number of features (10) gained $10-20 \%$ in area, with a total area change of $0.442 \pm 0.423 \mathrm{~km}^{2}$ and an average area change of $0.044 \mathrm{~km}^{2}$. For the longer timer period of $1957-1990$ the bins 
with the largest number of feature (9) (16\%), lost $50-60 \%$ and $30-40 \%$ with an area change of $-0.443 \pm 0.243 \mathrm{~km}^{2}$ and $-0.396 \pm 0.186 \mathrm{~km}^{2}$ and an average area of $-0.049 \mathrm{~km}^{2}$ and $-0.044 \mathrm{~km}^{2}$.

Table 10. The distribution of glacier and perennial snowfields with significant area change for the five time periods.

\begin{tabular}{cccccc}
\hline \hline \multicolumn{7}{c}{ Bin Count } \\
\hline Bins & $1949-2003$ & $\mathbf{1 9 4 9 - 1 9 5 7}$ & $\mathbf{1 9 4 9 - 1 9 9 0}$ & $\mathbf{1 9 5 7 - 1 9 9 0}$ & $\mathbf{1 9 9 0 - 2 0 0 3}$ \\
\hline$-100 \%$ & 1 & 0 & 0 & 0 & 0 \\
$-100 \%-90 \%$ & 10 & 0 & 19 & 4 & 1 \\
$-90 \%--80 \%$ & 15 & 0 & 10 & 3 & 0 \\
$-80 \%--70 \%$ & 12 & 2 & 12 & 1 & 1 \\
$-70 \%--60 \%$ & 14 & 3 & 7 & 6 & 3 \\
$-50 \%--60 \%$ & 12 & 3 & 11 & 9 & 2 \\
$-50 \%--40 \%$ & 6 & 2 & 11 & 7 & 2 \\
$-40 \%--30 \%$ & 9 & 3 & 8 & 9 & 6 \\
$-30 \%--20 \%$ & 5 & 8 & 9 & 5 & 8 \\
$-20 \%--10 \%$ & 6 & 6 & 7 & 5 & 7 \\
$-10 \%-0 \%$ & 5 & 4 & 7 & 1 & 15 \\
$0 \%-10 \%$ & 8 & 8 & 6 & 5 & 10 \\
$10 \%-20 \%$ & 1 & 10 & 2 & 0 & 4 \\
$20 \%-30 \%$ & 2 & 5 & 0 & 0 & 1 \\
$30 \%-40 \%$ & 0 & 4 & 0 & 0 & 3 \\
$40 \%-50 \%$ & 0 & 0 & 0 & 0 & 2 \\
$50 \%-60 \%$ & 0 & 1 & 0 & 0 & 1 \\
$60 \%-70 \%$ & 0 & 0 & 0 & 0 & 1 \\
$70 \%-80 \%$ & 0 & 0 & 0 & 0 & 0 \\
$80 \%-90 \%$ & 0 & 0 & 0 & 0 & 0 \\
$90 \%-100 \%$ & 0 & 0 & 0 & 0 & 0 \\
$>100 \%$ & 0 & 0 & 0 & 0 & 0 \\
\hline Total & 106 & 59 & 109 & 55 & 67 \\
\hline & & & & & \\
\hline
\end{tabular}

For $1949-1990$ the bin with the largest number of features $19(17 \%)$ lost $90-100 \%$ in area with no feature gaining over $20 \%$. The total area change is $-0.301 \pm$ $0.105 \mathrm{~km}^{2}$ with an average area change of $-0.016 \mathrm{~km}^{2}\left(-0.013 \mathrm{~km}^{2}\right)$. For the longest time period of $1949-2003$, the bin with the largest number of features 15 (14\%) lost $80-90 \%$ 
in area with no feature gaining more than $20 \%$. The total area change is $-0.169 \pm 0.104$ $\mathrm{km}^{2}$ with an average area change of $-0.013 \mathrm{~km}^{2}$. For $1990-2003$, the bin with the largest number of features $15(22 \%)$ lost $0-10 \%$. The significant area change is $-0.032 \pm 0.097$ $\mathrm{km}^{2}$ with an average area change of $-0.003 \mathrm{~km}^{2}$. Since smaller glaciers $\left(<0.1 \mathrm{~km}^{2}\right)$, which have more variability, dominate populations it is expected to see insignificant change when examining relatively short time periods.

In the shorter time periods of 1949-1957 and 1990-2003 five and seven glaciers respectively exhibited a significant positive change of greater than $30 \%$. The 5 significant glaciers area represent $3.78 \%\left(0.335 \mathrm{~km}^{2}\right)$ of the total area for 1957 with an average of $0.067 \mathrm{~km}^{2}$ and the seven glaciers represent $0.6 \%\left(0.043 \mathrm{~km}^{2}\right)$ of the total for 2003 with an average of $0.006 \mathrm{~km}^{2}$. These features are perennial snow patches; which show greater variability due to seasonal snow cover masking their true perennial boundaries. To assess whether size has an influence on the fractional area change (FAC), change divided by initial area plotted against area was calculated (Figure 12). Overall, smaller glaciers show greater uncertainty and more variability compared to larger glaciers over shorter time periods, less so in longer time periods (Table 11). The largest variability occurred in glacier $<0.1 \mathrm{~km}^{2}$ from $1990-2003(-100 \%$ to $68.3 \%)$.

Table 11. The magnitude of variability of significant area change for glaciers and perennial snowfields for the 5 inventory comparisons. Area is in $\mathrm{km}^{2}$.

\begin{tabular}{|c|c|c|c|c|c|c|c|c|c|c|}
\hline \multirow[b]{2}{*}{ Area } & \multicolumn{2}{|c|}{$1949-2003$} & \multicolumn{2}{|c|}{ 1949-1957 } & \multicolumn{2}{|c|}{ 1949-1990 } & \multicolumn{2}{|c|}{ 1957-1990 } & \multicolumn{2}{|c|}{$1990-2003$} \\
\hline & $<0.1$ & $\geq 0.1$ & $<0.1$ & $\geq 0.1$ & $<0.1$ & $\geq 0.1$ & $<0.1$ & $\geq 0.1$ & $<0.1$ & $\geq 0.1$ \\
\hline Min & $-100 \%$ & $-69 \%$ & $-78 \%$ & $-29 \%$ & $-99 \%$ & $-62 \%$ & $-99 \%$ & $-61 \%$ & $-92 \%$ & $-16 \%$ \\
\hline Max & $25 \%$ & $9 \%$ & $35 \%$ & $51 \%$ & $13 \%$ & $18 \%$ & $-2 \%$ & $18 \%$ & $69 \%$ & $11 \%$ \\
\hline
\end{tabular}


It's evident that changes in larger glacier and perennial snowfields have smaller relative uncertainties while smaller features show higher relative uncertainties consistent with initial relative uncertainty (Figure 13). Consequently, longer time intervals show more significant change in the small features.
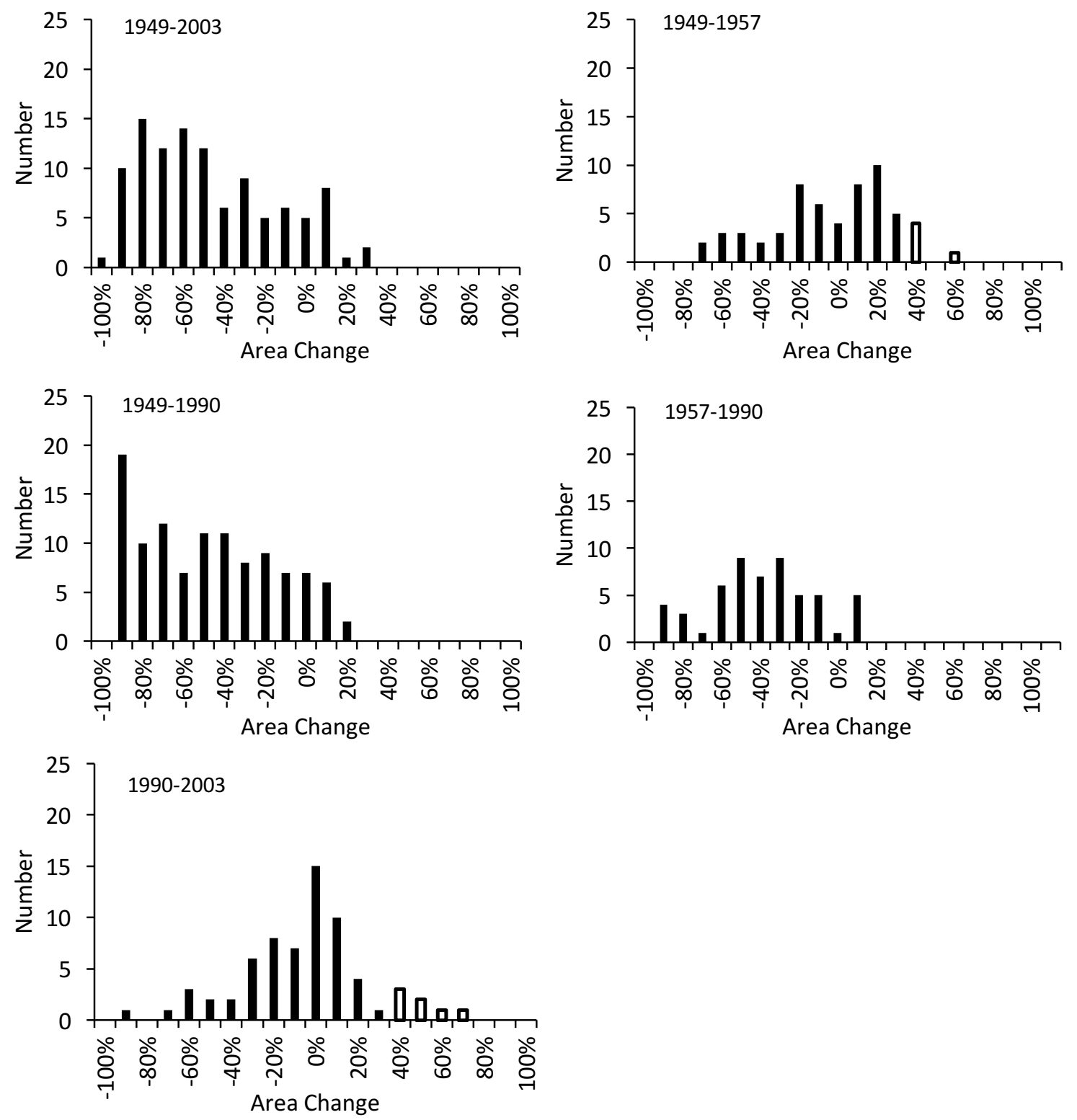

Figure 12. Histograms of the significant area change. Number is number of glaciers. The value of each bin percent range is the maximum of that grouping. Open bars represent perennial snow patches masked by seasonal snow cover resulting in $>30 \%$ change. 
The fractional area plots show that with increasing glacier and perennial snowfield area the uncertainty gets smaller and greater time spans are skewed away from $0 \%$.
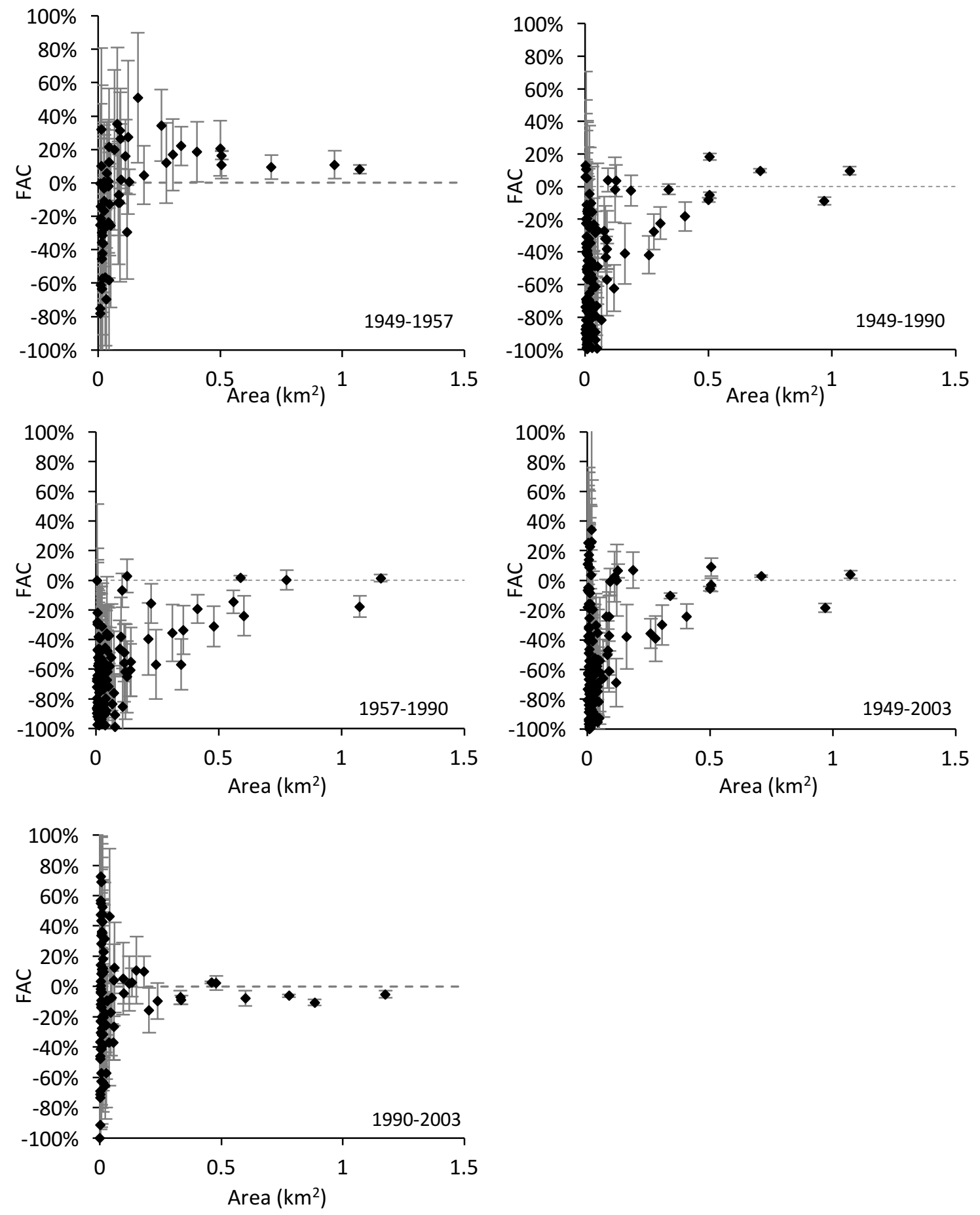

Figure 13. The fractional area plots for significant change glacier and perennial snowfields for 1949-1957, 1957-1990, 1949-1990, 1949-2003, and 1990-2003. 


\section{The 15 Named Glaciers}

\section{Results}

The 15 named glaciers account for $72 \%\left(7.16 \pm 1.22 \mathrm{~km}^{2}\right)$ of the total ice-covered area and 15 of the 122 glaciers and perennial snowfields on the Three Sisters in 1957 (Figure 14).

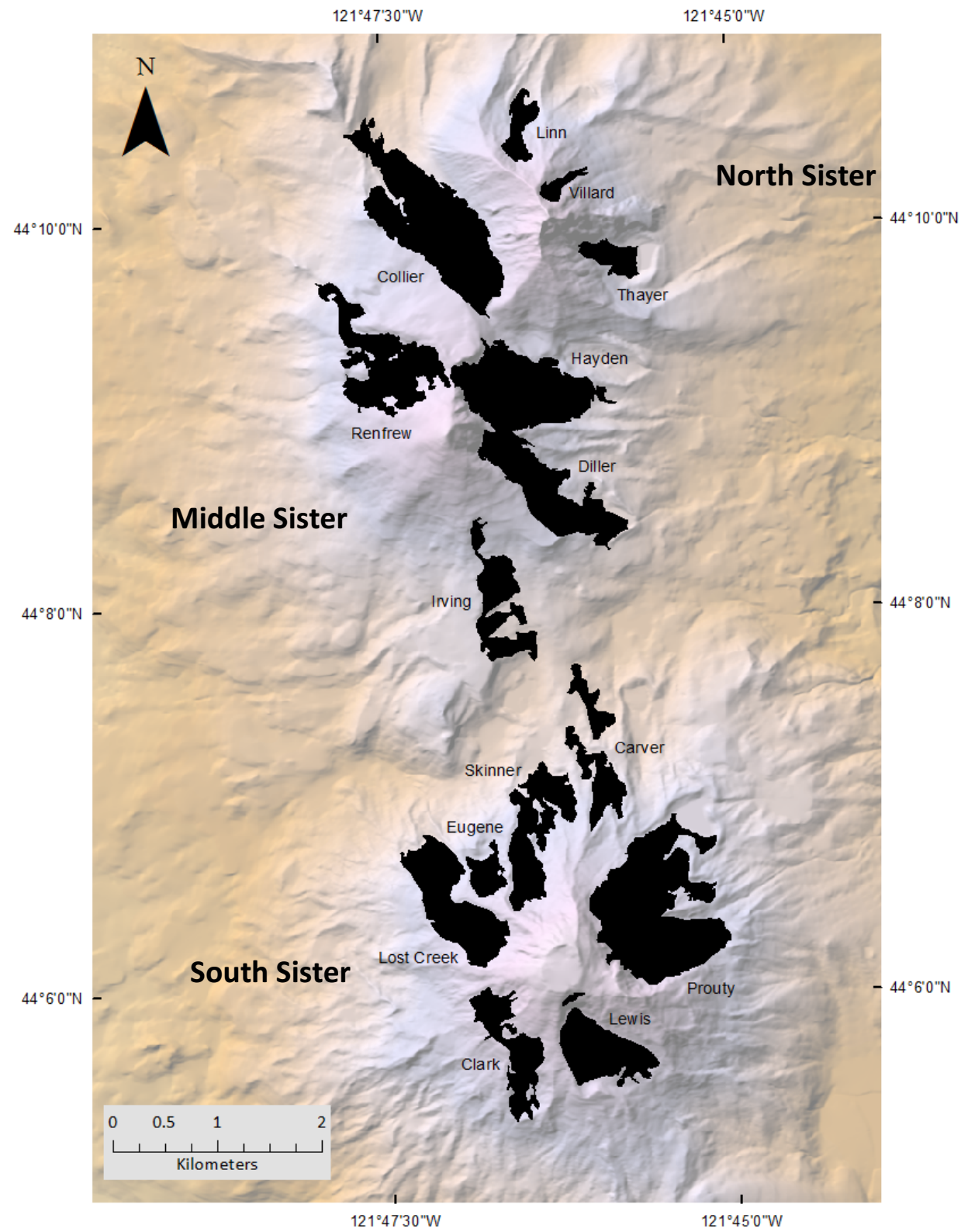

Figure 14. Location of the 15 named glaciers, in black, on the Three Sisters in 1957. The Eugene, Linn, Thayer, and Villard glaciers were identified as non-glaciers in 1990. Map is in WGS 84 UTM Zone 10. 
Their average area $\left(0.477 \mathrm{~km}^{2}\right)$ is much larger than the average glacier and perennial snowfield $\left(0.091 \mathrm{~km}^{2}\right)$ and their average elevation is $2548 \mathrm{~m}$, which is higher than the glacier population ( $2428 \mathrm{~m}$ ). The Villard Glacier is the highest mean elevation $2773 \mathrm{~m}$ and Carver Glacier is the lowest (2328 m) in 1957. All 15 glaciers met the critical shear stress threshold to define movement in 1957. Like the total glacier and perennial snowfield population they face all directions. Their range of areas span that of the entire glacier and perennial snowfield population on the mountains with 4 that have areas between $0.05-0.2 \mathrm{~km}^{2}, 5$ between $0.2-0.5 \mathrm{~km}^{2}, 4$ between $0.5-0.8 \mathrm{~km}^{2}$, and 2 larger than $0.8 \mathrm{~km}^{2}$ (Figure 15; Table 12).

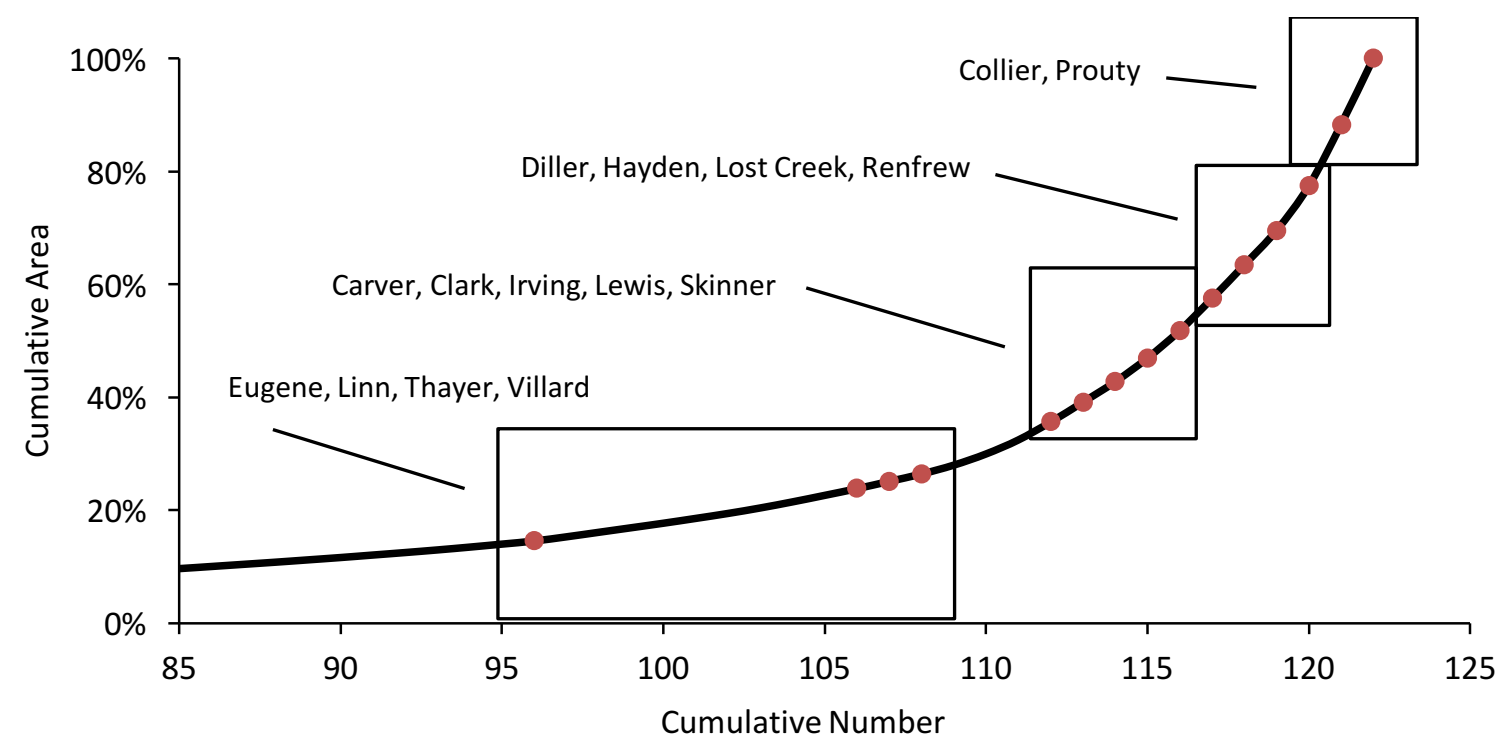

Figure 15. Cumulative area total of the glacier inventory in 1957 with the 15 named glaciers in red.

I used the zonal statistic package in ArcGIS to derive averages, minimums, and maximums for each glacier's elevation, elevation difference (highest elevation 
subtracted from lowest), slope, and aspect for the 15 named glaciers, using the 195710 $m$ NED DEM (Table 12) and compare it to the topographic statistics for other years to observe how they have been changing. Finally, I examine Collier Glacier because it has the most comprehensive data set of all the glaciers.

Table 12. Area, average elevation, elevation difference, average slope, and average aspect of the 15 named glaciers. The characteristics date to 1957 from the USGS 24,000 topographic maps.

\begin{tabular}{|c|c|c|c|c|c|c|}
\hline Glacier & Volcano & Area $\left(\mathrm{km}^{2}\right)$ & Elevation (m) & $\begin{array}{c}\text { Elevation } \\
\text { Difference }(\mathrm{m})\end{array}$ & Slope $\left({ }^{\circ}\right)$ & Aspect $\left({ }^{\circ}\right)$ \\
\hline Collier & North & $1.074 \pm 0.153$ & 2483 & 545 & 19 & 349 \\
\hline Linn & North & $0.126 \pm 0.008$ & 2507 & 389 & 28 & 7 \\
\hline Thayer & North & $0.129 \pm 0.043$ & 2434 & 300 & 25 & 94 \\
\hline Villard & North & $0.054 \pm 0.008$ & 2773 & 393 & 39 & 51 \\
\hline Diller & Middle & $0.588 \pm 0.017$ & 2496 & 457 & 21 & 82 \\
\hline Hayden & Middle & $0.776 \pm 0.101$ & 2592 & 521 & 20 & 90 \\
\hline Irving & Middle & $0.357 \pm 0.117$ & 2347 & 386 & 15 & 127 \\
\hline Renfrew & Middle & $0.604 \pm 0.164$ & 2623 & 492 & 19 & 297 \\
\hline Carver & South & $0.313 \pm 0.120$ & 2328 & 348 & 16 & 16 \\
\hline Clark & South & $0.347 \pm 0.107$ & 2712 & 360 & 20 & 219 \\
\hline Eugene & South & $0.117 \pm 0.037$ & 2522 & 190 & 25 & 345 \\
\hline Lewis & South & $0.414 \pm 0.078$ & 2766 & 457 & 18 & 145 \\
\hline Lost Creek & South & $0.561 \pm 0.085$ & 2545 & 536 & 20 & 324 \\
\hline Prouty & South & $1.160 \pm 0.042$ & 2617 & 576 & 21 & 42 \\
\hline Skinner & South & $0.048 \pm 0.130$ & 2469 & 485 & 20 & 350 \\
\hline Mean & & 0.477 & 2548 & & 22 & \\
\hline Max. & & 1.234 & 2773 & & 39 & \\
\hline Min. & & 0.054 & 2328 & & 16 & \\
\hline Total & & $7.10 \pm 0.369$ & & & & \\
\hline
\end{tabular}

The Little Ice Age (LIA) extents for the 15 named glaciers were derived from LIA moraine locations which record the extent of the glacier at $\sim 1900$ when glaciers started to recede. Historic photos from 1903 (Russell, 1905) confirm that glaciers were at or near these neoglacial moraine crests (O'Connor et al., 2001), which is true in other regions around the American West (Basagic and Fountain, 2011; Dick, 2013). O'Connor et al. (2001) mapped the moraines and calculated LIA areas and I remapped the moraine crests from the 1990 aerial orthophotographs, to be sure the mapping was consistent 
with my methods and to produce digital files of glacier perimeters. The 1990 orthophotographs were used because they are an excellent high quality color image, which enhances contrast.

Hodge (1925) published the earliest account of glacier extent and surface area on the Three Sisters. He included areas of the 15 named glaciers, photos, and a map of the region, however no explanation of methods was given.

Cannon et al. (unpublished) used oblique aerial and ground-based photographs to digitized glacier extents from 1935 to 2007. Their study included surface area and uncertainty calculations for 9 of the 15 glaciers, including: Clark, Collier, Diller, Eugene, Hayden, Lost Creek, Prouty, Renfrew, and Thayer. The surface areas that were used for the temporal study are the outlines from 1935 and 2007.

Areas were defined for the 15 named glaciers for 1900 (LIA), 1949, 1957, 1990, and 2003 from this thesis and data were collected from other studies for 1925, 1937, and 2007 (Hodge, 1925; Cannon and Leonard, unpublished) (Table 13). Of all the named glaciers, Collier Glacier has one of the most extensive records of the glaciers on the Three Sisters: 1900, 1925, 1935, 1949, 1957, 1990, 2003, and 2007. Previous studies area estimates for Collier Glacier (McDonald, 1995; Jackson, 2007; Beedlow, 2010) were not used because these studies defined a smaller area of the glacier, as a result, their specific studies were not used. They excluded areas of ice no longer flowing to the main terminus, however, for the purpose of glacial inventories, this area is important to quantify. 
Table 13. Named glaciers with the number of extents and the year.

\begin{tabular}{lcc}
\hline \hline \multicolumn{1}{c}{ Glacier } & $\begin{array}{c}\text { Number of } \\
\text { Glacier Extents }\end{array}$ & \multicolumn{1}{c}{ Years } \\
\hline Carver & 6 & $1900,1925,1949,1957,1990,2003$ \\
Clark & 8 & $1900,1925,1937,1949,1957,1990,2003,2007$ \\
Collier & 10 & $1900,1910,1925,1931,1937,1949,1957,1990,2003,2007$ \\
Diller & 8 & $1900,1925,1937,1949,1957,1990,2003,2007$ \\
Eugene & 8 & $1900,1925,1937,1949,1957,1990,2003,2007$ \\
Hayden & 8 & $1900,1925,1937,1949,1957,1990,2003,2007$ \\
Irving & 6 & $1900,1925,1949,1957,1990,2003$ \\
Lewis & 6 & $1900,1925,1949,1957,1990,2003$ \\
Linn & 7 & $1900,1925,1949,1957,1990,2003$ \\
Lost Creek & 8 & $1900,1925,1937,1949,1957,1990,2003,2007$ \\
Prouty & 8 & $1900,1925,1937,1949,1957,1990,2003,2007$ \\
Renfrew & 8 & $1900,1925,1937,1949,1957,1990,2003,2007$ \\
Skinner & 6 & $1900,1925,1949,1957,1990,2003$ \\
Thayer & 7 & $1900,1925,1937,1949,1957,2003,2007$ \\
Villard & 6 & $1900,1925,1949,1957,1990,2003$ \\
\hline
\end{tabular}

Area for the LIA of the 15 glaciers calculated by O'Connor et al. (2001) were found to be close to the area's I calculated except for the Lewis and Villard glaciers (Table 14). The LIA extents of these two glaciers were difficult to determine because of the lack of welldefined terminal and lateral moraines. To define an area for each of these glaciers, I averaged the area I estimated with the estimate by O'Connor et al. (2001). The area for the remaining 13 glaciers came from my digitized outlines. The uncertainty for the LIA outlines was estimated by applying a buffer. 
Table 14. Comparison of the 15 named glaciers LIA areas from the digitized areas and O'Connor et al. (2001). All areas are in $\mathrm{km}^{2}$.

\begin{tabular}{lcc}
\hline \multicolumn{1}{c}{ Glacier } & Digitized Area & O'Connor Area \\
\hline Carver & $1.172 \pm 0.164$ & 1.347 \\
Clark & $0.448 \pm 0.091$ & 0.464 \\
Collier & $2.157 \pm 0.172$ & 2.236 \\
Diller & $1.070 \pm 0.117$ & 1.031 \\
Eugene & $0.324 \pm 0.080$ & 0.210 \\
Hayden & $1.054 \pm 0.120$ & 1.635 \\
Irving & $0.430 \pm 0.087$ & 0.388 \\
Lewis & $0.558 \pm 0.061$ & 1.329 \\
Linn & $0.266 \pm 0.066$ & 0.280 \\
Lost Creek & $0.654 \pm 0.105$ & 0.788 \\
Prouty & $1.878 \pm 0.164$ & 1.905 \\
Renfrew & $0.682 \pm 0.136$ & 0.664 \\
Skinner & $0.721 \pm 0.053$ & 0.689 \\
Thayer & $0.243 \pm 0.045$ & 0.290 \\
Villard & $0.055 \pm 0.024$ & 0.541 \\
\hline Total & $\mathbf{1 1 . 7 1} \pm \mathbf{0 . 4 1 7}$ & $\mathbf{1 3 . 8 0}$ \\
\hline
\end{tabular}

The area of all 15 glaciers decreased over the past century (Table 15). Total area loss from 1900 to 2003 is $-6.70 \pm 0.439 \mathrm{~km}^{2}(-54.2 \%)$, ranging from $-0.129 \pm 0.046 \mathrm{~km}^{2}$ $(-53.1 \%)$ at Thayer Glacier to $-1.36 \pm 0.177 \mathrm{~km}^{2}(-63.1 \%)$ at Collier Glacier, with an average area loss of $56 \%$. The area changes exhibited a cycle of rapid retreat, advance/stabilization, and continued slower retreat (Table 16). The largest change occurred from 1900 to 1949 when glacier area decreased by $-6.12 \pm 0.440 \mathrm{~km}^{2}$ (-49.6\%). Between 1949 and 1957 glacier area increased by $0.926 \pm 0.394 \mathrm{~km}^{2}$ (15\%) as compared to the 1949 area, with the uncertainty being larger than the area change. Between 1957 and 1990 area decreased by $-1.33 \pm 0.379 \mathrm{~km}^{2}$ (-19\%). From 1990 to 2003 area continued to decrease slightly $-0.172 \pm 0.162 \mathrm{~km}^{2}(-2.9 \%)$. 
Table 15. Areas for the 15 named glaciers. Areas italicized and bolded (1990 - Thayer and Villard glaciers) area estimates not direct measurements.

\begin{tabular}{|c|c|c|c|c|c|c|c|c|}
\hline Glacier & LIA 1900 & 1925 & 1937 & 1949 & 1957 & 1990 & 2003 & 2007 \\
\hline Carver & $1.172 \pm 0.164$ & 0.618 & - & $0.279 \pm 0.060$ & $0.313 \pm 0.120$ & $0.202 \pm 0.002$ & $0.170 \pm 0.060$ & - \\
\hline Clark & $0.448 \pm 0.091$ & 0.156 & $0.127 \pm 0.024$ & $0.259 \pm 0.030$ & $0.347 \pm 0.107$ & $0.150 \pm 0.052$ & $0.166 \pm 0.042$ & $0.095 \pm 0.019$ \\
\hline Collier & $2.157 \pm 0.172$ & 1.789 & $1.315 \pm 0.027$ & $0.969 \pm 0.046$ & $1.074 \pm 0.153$ & $0.883 \pm 0.012$ & $0.790 \pm 0.032$ & $0.795 \pm 0.042$ \\
\hline Diller & $1.070 \pm 0.117$ & 0.784 & $0.533 \pm 0.003$ & $0.505 \pm 0.018$ & $0.588 \pm 0.017$ & $0.598 \pm 0.007$ & $0.551 \pm 0.060$ & $0.428 \pm 0.025$ \\
\hline Eugene & $0.324 \pm 0.080$ & 0.401 & $0.098 \pm 0.002$ & $0.089 \pm 0.012$ & $0.117 \pm 0.037$ & $0.060 \pm 0.027$ & $0.068 \pm 0.024$ & $0.057 \pm 0.003$ \\
\hline Hayden & $1.054 \pm 0.120$ & 0.931 & $0.740 \pm 0.001$ & $0.709 \pm 0.001$ & $0.776 \pm 0.101$ & $0.778 \pm 0.014$ & $0.730 \pm 0.002$ & $0.694 \pm 0.003$ \\
\hline Irving & $0.430 \pm 0.087$ & 0.249 & - & $0.305 \pm 0.060$ & $0.357 \pm 0.117$ & $0.237 \pm 0.002$ & $0.214 \pm 0.057$ & - \\
\hline Lewis & $0.943 \pm 0.061$ & 0.108 & - & $0.340 \pm 0.011$ & $0.414 \pm 0.078$ & $0.334 \pm 0.018$ & $0.304 \pm 0.007$ & - \\
\hline Linn & $0.266 \pm 0.066$ & 0.160 & - & $0.126 \pm 0.008$ & $0.127 \pm 0.017$ & $0.131 \pm 0.023$ & $0.134 \pm 0.009$ & $0.143 \pm 0.009$ \\
\hline Lost Creek & $0.654 \pm 0.105$ & 0.759 & $0.566 \pm 0.014$ & $0.505 \pm 0.010$ & $0.561 \pm 0.085$ & $0.479 \pm 0.016$ & $0.490 \pm 0.042$ & $0.506 \pm 0.005$ \\
\hline Prouty & $1.878 \pm 0.164$ & 0.666 & $1.097 \pm 0.040$ & $1.072 \pm 0.040$ & $1.160 \pm 0.042$ & $1.175 \pm 0.036$ & $1.115 \pm 0.040$ & $0.709 \pm 0.022$ \\
\hline Renfrew & $0.682 \pm 0.136$ & 0.748 & $0.578 \pm 0.007$ & $0.500 \pm 0.014$ & $0.604 \pm 0.164$ & $0.459 \pm 0.004$ & $0.472 \pm 0.005$ & $0.460 \pm 0.041$ \\
\hline Skinner & $0.721 \pm 0.053$ & 0.383 & - & $0.405 \pm 0.066$ & $0.481 \pm 0.130$ & $0.331 \pm 0.027$ & $0.307 \pm 0.013$ & - \\
\hline Thayer & $0.243 \pm 0.045$ & 0.227 & $0.098 \pm 0.014$ & $0.111 \pm 0.023$ & $0.129 \pm 0.043$ & $0.105 \pm 0.030$ & $0.114 \pm 0.030$ & $0.043 \pm 0.011$ \\
\hline Villard & $0.298 \pm 0.024$ & 0.082 & - & $0.045 \pm 0.004$ & $0.054 \pm 0.008$ & $0.044 \pm 0.006$ & $0.021 \pm 0.006$ & - \\
\hline Total & $12.34 \pm 0.417$ & 8.061 & & $6.22 \pm 0.140$ & $7.10 \pm 0.369$ & $5.97 \pm 0.089$ & $5.65 \pm 0.135$ & \\
\hline$\Delta$ from 1900 & & & & $-6.12 \pm 0.440$ & $-5.19 \pm 0.557$ & $-6.52 \pm 0.427$ & $-6.70 \pm 0.439$ & \\
\hline \% Change & & & & $-49.6 \%$ & $-42.4 \%$ & $-51.6 \%$ & $-54.2 \%$ & \\
\hline
\end{tabular}



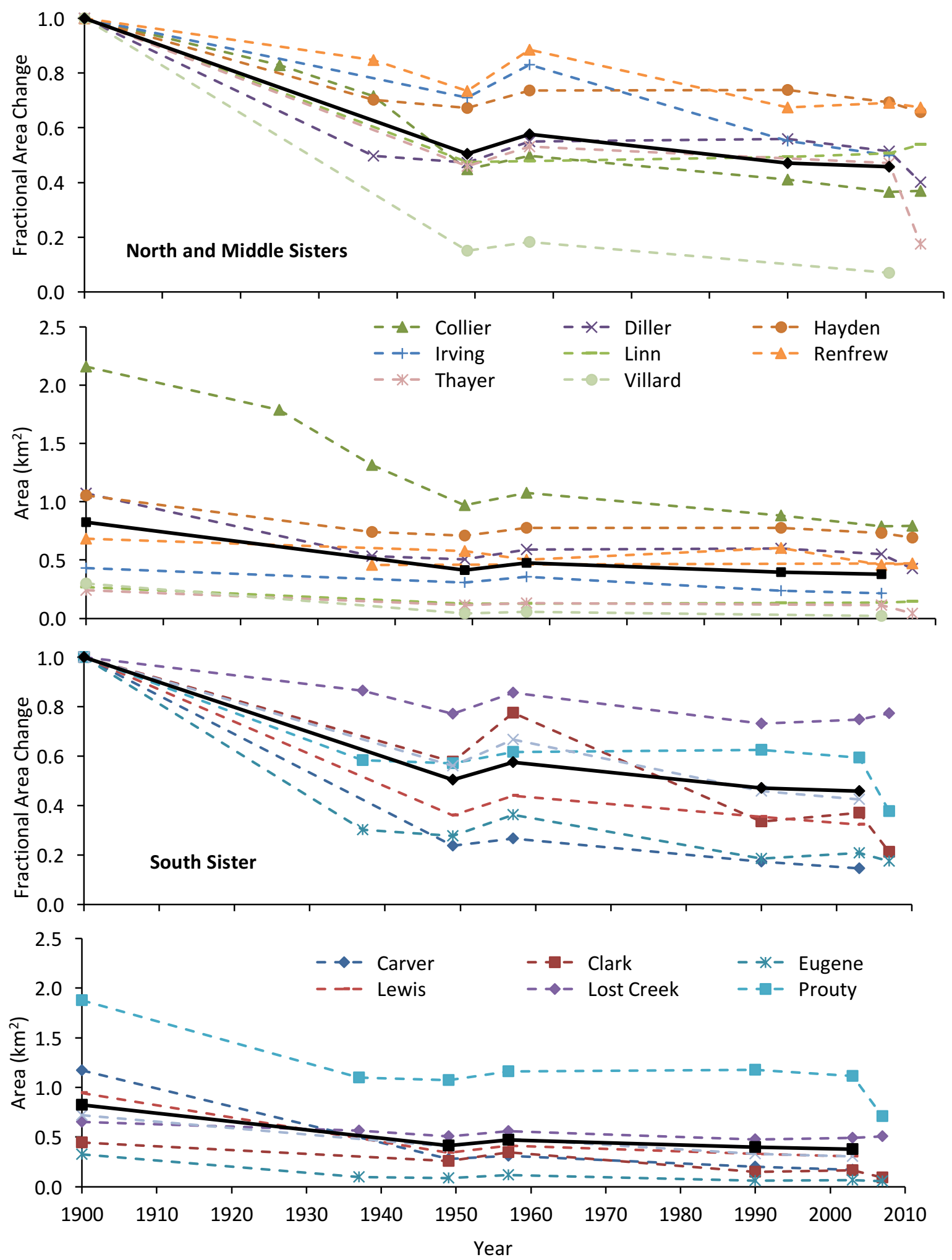

Figure 16. Glacier area change for North \& Middle (top two) and South (bottom two) Sisters expressed in area change $\left(\mathrm{km}^{2}\right)$ and fractional area change. Solid black line on the graphs is average FAC and area for all the 15 named glaciers. Note that the uncertainty bars are not shown because it is smaller than the symbols. 
Four glaciers, the Hayden, Diller, Linn, and Prouty glaciers increased or stayed the same size from 1957-1990 then returned to a decreasing trend from 1990-2003. The four glaciers probably advanced due to debris covered ice. The Villard Glacier lost $-2.53 \pm$ $0.024(-84.9 \%)$ from $\sim 1900-1949$, which is a larger change compared to the other glaciers. In this case, the LIA area was difficult to determine because of poorly preserved landscape modification. This could be causing the higher rate of loss as compared to the glaciers. Overall, the 15 named glaciers responded synchronously.

To evaluate topographic influence on area change I compared four topographic characteristics, mean elevation, elevation difference, slope, and aspect, from $\sim 1900$ to 2003 (Table 12). Average elevation $\left(r^{2}=0.01, p<0.05\right)$, slope $\left(r^{2}=0.07, p<0.05\right)$, and aspect $\left(r^{2}=0.01, p<0.05\right)$ showed poor correlation and statistical insignificance with glacier change from 1900-2003 (Figure 17). The best correlation $\left(r^{2}=0.22, p<0.05\right)$ was observed with elevation difference, glaciers with larger elevation ranges experienced less glacier loss suggesting higher elevations on larger glaciers are compensating for losses in the lower elevations. The evaluation of the different time period's relationships also showed no strong or consistent correlation between any one topographic characteristic.

It was observed that some glaciers with extensive debris cover on their surfaces showed areas of glacier advance. To investigate a relationship between debris cover and glacier advance/retreat I estimated the fraction of glacier area covered with rock debris and compared it to area change (Figure 18). The area of debris cover was estimated from the aerial and remote imagery. The total area of debris-covered ice 
increased over the 1949-2003 period. The largest increase was 53\% between 1957 and $1990,0.46 \pm 0.006 \mathrm{~km}^{2}$ in 1957 to $0.97 \pm 0.010 \mathrm{~km}^{2}$ in 1990 .
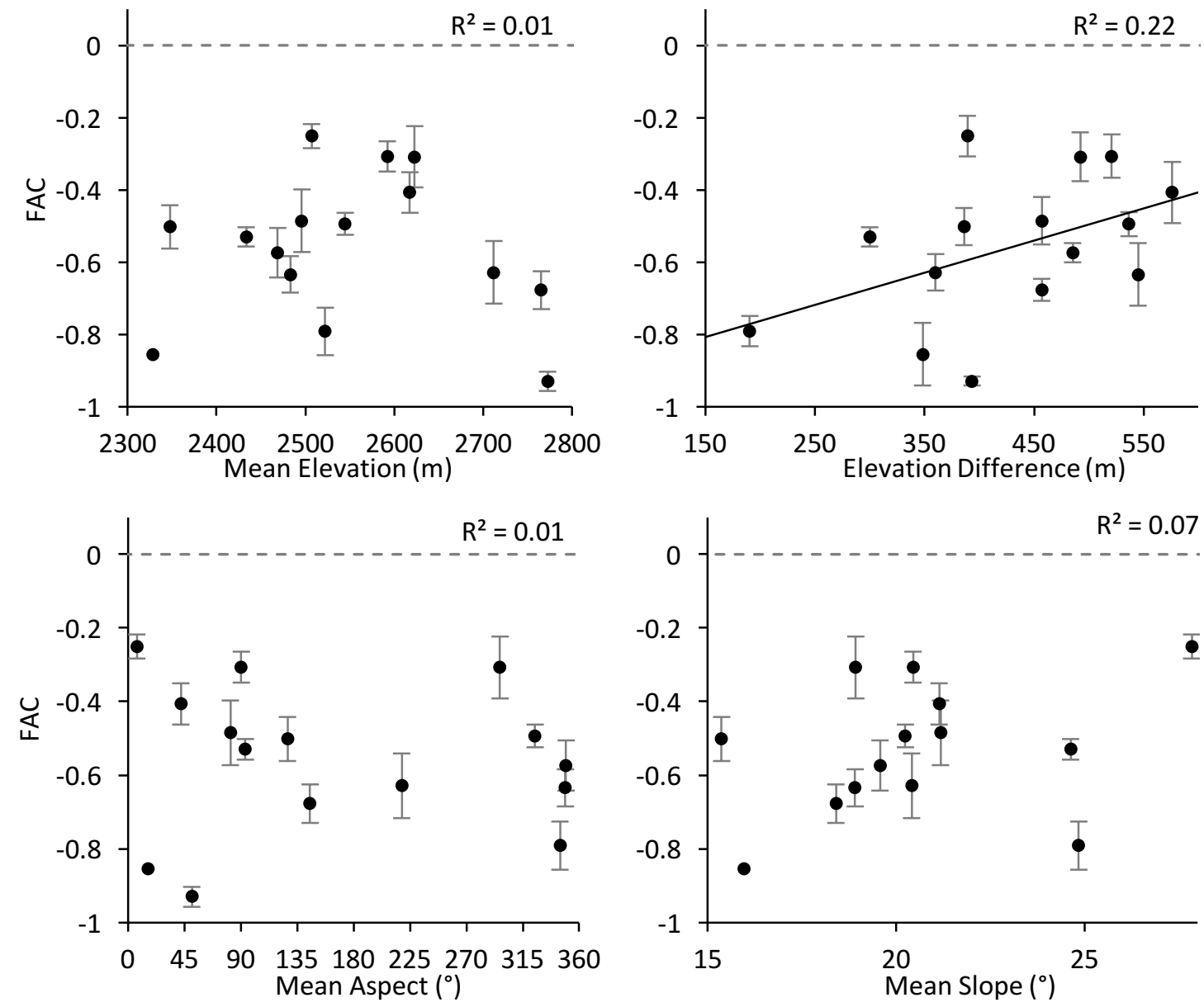

Figure 17. Glacier area change (1900-2003) as a function of average elevation, slope, aspect, and elevation difference. Topographic data from 1957.

A correlation is observed between the area change from 1949-2003 to debris cover for each glacier $\left(r^{2}=0.19\right)$ (Figure 18). It shows that with increasing debris cover the amount of area change decreases. This increase of debris covering ice could account for the glaciers not losing as much area in the latter half of the century as quickly as the first half. 

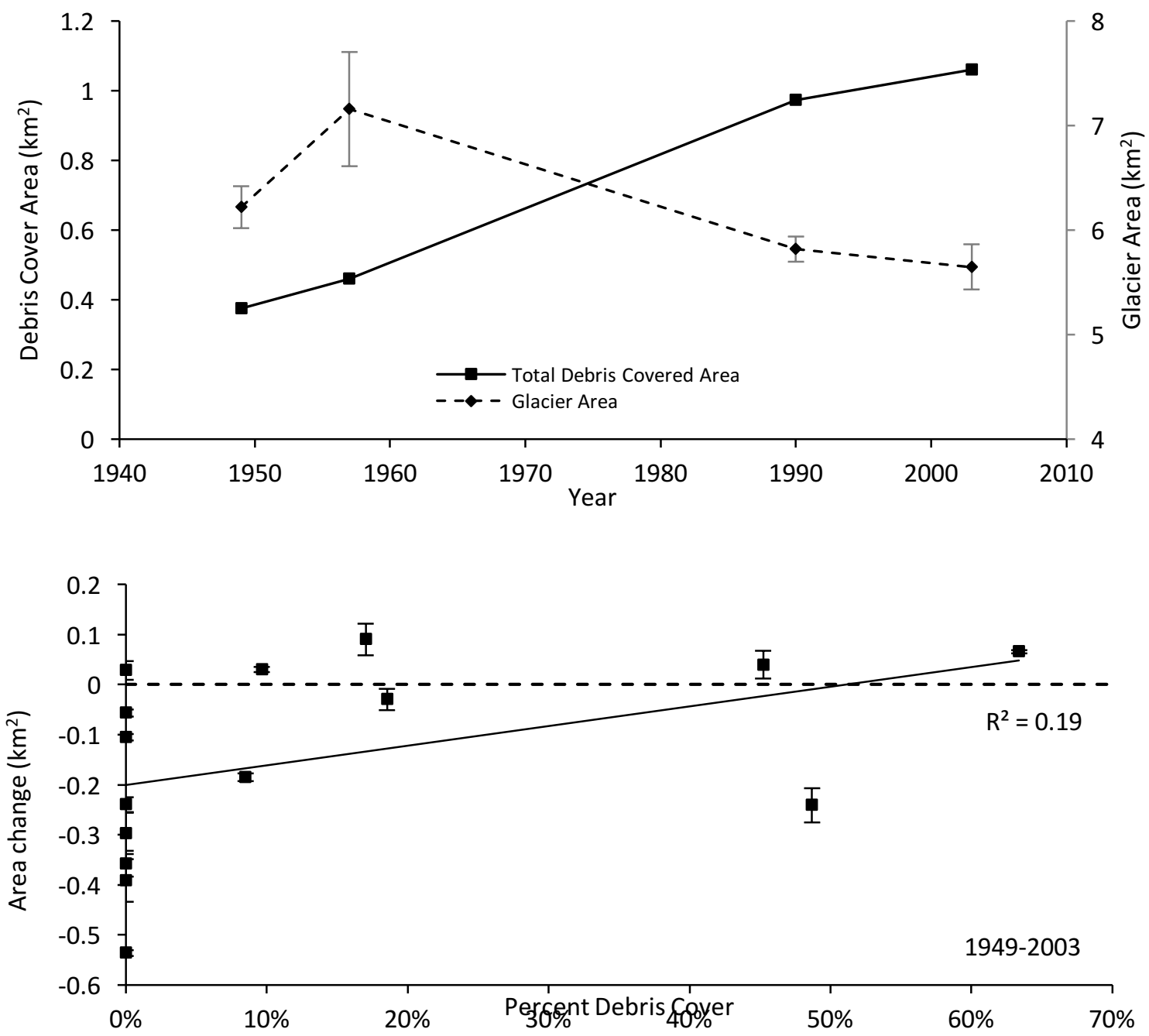

Figure 18. Effect of debris-cover on glacier change. Top - Total area of debris covered ice and total glacier area from 1949 to 2003 of the 15 named glaciers. Bottom - The area change $\left(\mathrm{km}^{2}\right)$ and percent debris cover of the 15 named glaciers from 1949-2003. Note that the uncertainty bars for the debris covered area and area change are not shown because it is smaller than the symbols.

\section{Collier Glacier}

Collier Glacier has the most extensive record of all the glaciers on the Three

Sisters. Generally, Collier followed the same advance/retreat behavior as the other glaciers on the Three Sisters (Figure 19). The magnitude of area changes is roughly similar to the other glaciers in time periods with data. Collier seems to be a reasonable 
index glacier for the region.

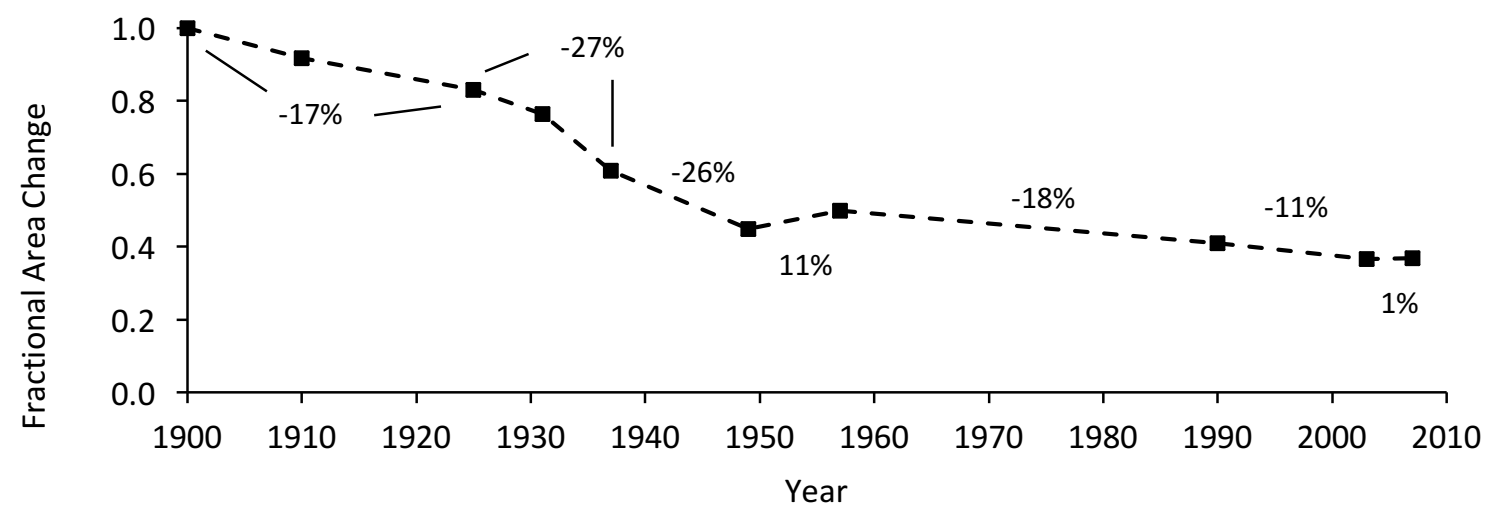

Figure 19. FAC based on 1900 area and change percentages of Collier Glacier from 1900 to 2007 showing the calculated changes between years of area data. All area data are included in Table 15 and 16 except for 1910 and 1931 which are $1.98 \pm 0.16 \mathrm{~km}^{2}$ and $1.65 \pm 0.14 \mathrm{~km}^{2}$, respectively. Note: the uncertainty bars are not shown because it is smaller than the symbols.

The areas for $1910,1.98 \pm 0.16 \mathrm{~km}^{2}$, and $1931,1.65 \pm 0.14 \mathrm{~km}^{2}$ were estimated from Collier map in O'Connor et al (2001), which was based on ground-based oblique photographs. I used Collier to interpolate the area change from 1925 and 1937 for the glaciers that are missing data (Table 16). 
Table 16. Updated areas $\left(\mathrm{km}^{2}\right)$ of the 15 named glaciers from estimated (Italics and bold) areas for 1925 and 1937 for the using Collier as a reference.

\begin{tabular}{|c|c|c|c|c|c|c|c|c|}
\hline Glacier & LIA 1900 & 1925 & 1937 & 1949 & 1957 & 1990 & 2003 & 2007 \\
\hline Carver & $1.172 \pm 0.164$ & $0.902 \pm 0.470$ & $0.555 \pm 0.044$ & $0.279 \pm 0.060$ & $0.313 \pm 0.120$ & $0.202 \pm 0.002$ & $0.170 \pm 0.060$ & - \\
\hline Clark & $0.448 \pm 0.091$ & $0.372 \pm 0.194$ & $0.127 \pm 0.024$ & $0.259 \pm 0.030$ & $0.347 \pm 0.107$ & $0.150 \pm 0.052$ & $0.166 \pm 0.042$ & $0.095 \pm 0.019$ \\
\hline Collier & $2.157 \pm 0.172$ & $1.789 \pm 0.933$ & $1.315 \pm 0.027$ & $0.969 \pm 0.046$ & $1.074 \pm 0.153$ & $0.883 \pm 0.012$ & $0.790 \pm 0.032$ & $0.795 \pm 0.042$ \\
\hline Diller & $1.070 \pm 0.117$ & $0.930 \pm 0.485$ & $0.533 \pm 0.003$ & $0.505 \pm 0.018$ & $0.588 \pm 0.017$ & $0.598 \pm 0.007$ & $0.551 \pm 0.060$ & $0.428 \pm 0.025$ \\
\hline Eugene & $0.324 \pm 0.080$ & $0.255 \pm 0.133$ & $0.098 \pm 0.002$ & $0.089 \pm 0.012$ & $0.117 \pm 0.037$ & $0.060 \pm 0.027$ & $0.068 \pm 0.024$ & $0.057 \pm 0.003$ \\
\hline Hayden & $1.054 \pm 0.120$ & $0.967 \pm 0.504$ & $0.740 \pm 0.001$ & $0.709 \pm 0.001$ & $0.776 \pm 0.101$ & $0.778 \pm 0.014$ & $0.730 \pm 0.002$ & $0.694 \pm 0.003$ \\
\hline Irving & $0.430 \pm 0.087$ & $0.372 \pm 0.194$ & $0.297 \pm 0.061$ & $0.305 \pm 0.060$ & $0.357 \pm 0.117$ & $0.237 \pm 0.002$ & $0.214 \pm 0.057$ & - \\
\hline Lewis & $0.943 \pm 0.061$ & $0.771 \pm 0.402$ & $0.549 \pm 0.081$ & $0.340 \pm 0.011$ & $0.414 \pm 0.078$ & $0.334 \pm 0.018$ & $0.304 \pm 0.007$ & - \\
\hline Linn & $0.266 \pm 0.066$ & $0.230 \pm 0.120$ & $0.185 \pm 0.033$ & $0.126 \pm 0.008$ & $0.127 \pm 0.017$ & $0.131 \pm 0.023$ & $0.134 \pm 0.009$ & $0.143 \pm 0.009$ \\
\hline Lost Creek & $0.654 \pm 0.105$ & $0.610 \pm 0.318$ & $0.566 \pm 0.014$ & $0.505 \pm 0.010$ & $0.561 \pm 0.085$ & $0.479 \pm 0.016$ & $0.490 \pm 0.042$ & $0.506 \pm 0.005$ \\
\hline Prouty & $1.878 \pm 0.164$ & $1.673 \pm 0.873$ & $1.097 \pm 0.040$ & $1.072 \pm 0.040$ & $1.160 \pm 0.042$ & $1.175 \pm 0.036$ & $1.115 \pm 0.040$ & $0.709 \pm 0.022$ \\
\hline Renfrew & $0.682 \pm 0.136$ & $0.625 \pm 0.326$ & $0.578 \pm 0.007$ & $0.500 \pm 0.014$ & $0.604 \pm 0.164$ & $0.459 \pm 0.004$ & $0.472 \pm 0.005$ & $0.460 \pm 0.041$ \\
\hline Skinner & $0.721 \pm 0.053$ & $0.610 \pm 0.318$ & $0.466 \pm 0.051$ & $0.405 \pm 0.066$ & $0.481 \pm 0.130$ & $0.331 \pm 0.027$ & $0.307 \pm 0.013$ & - \\
\hline Thayer & $0.243 \pm 0.045$ & $0.208 \pm 0.108$ & $0.098 \pm 0.014$ & $0.111 \pm 0.023$ & $0.129 \pm 0.043$ & $0.105 \pm 0.030$ & $0.114 \pm 0.030$ & $0.043 \pm 0.011$ \\
\hline Villard & $0.298 \pm 0.024$ & $0.223 \pm 0.116$ & $0.127 \pm 0.036$ & $0.045 \pm 0.004$ & $0.054 \pm 0.008$ & $0.044 \pm 0.006$ & $0.021 \pm 0.006$ & - \\
\hline Total & $12.34 \pm 0.417$ & $10.54 \pm 0.385$ & $7.331 \pm 0.143$ & $6.22 \pm 0.140$ & $7.10 \pm 0.369$ & $5.97 \pm 0.089$ & $5.65 \pm 0.135$ & \\
\hline$\Delta$ from 1900 & & $-1.80 \pm 0.568$ & $-5.01 \pm 0.441$ & $-6.12 \pm 0.440$ & $-5.19 \pm 0.557$ & $-6.52 \pm 0.427$ & $-6.70 \pm 0.439$ & \\
\hline \% Change & & -14.6 & -40.6 & -49.6 & -42.4 & -51.6 & -54.2 & \\
\hline
\end{tabular}


I used a ratio of the area change for Collier and set is equal to the same ratio for other 14 glaciers and solved for the unknown area,

$$
\frac{A_{C-1900}-A_{C-1925}}{A_{C-1900}-A_{C-2003}}=\frac{A_{x-1900}-A_{x-1925}}{A_{x-1900}-A_{x-2003}}
$$

were $A_{c}$ is the area of Collier $\left(\mathrm{km}^{2}\right)$ and $A_{x}$ is the area of the glacier that is being solved for $A_{x-1925}$ is the unknown. This was calculated using 1925 and 1937 data from Collier Glacier. The uncertainty was calculated by using the same method to estimate area for 1949, with the difference between that estimate and the measured 1949 area as the uncertainty. The estimates for 1925 were compared those areas to the results of Hodge (1925). His areas were treated suspect because his report lacked data collection information. I assumed that the Collier Glacier's area estimate to be the most accurate due to the lack of debris cover on the glacier surface clearly showing the glaciers boundary. I estimated the total area for 1925 to be $10.54 \pm 0.385 \mathrm{~km}^{2}$ this is larger than the Hodge (1925) estimate of $8.06 \mathrm{~km}^{2}$ (Table 17). The Diller, Eugene, Hayden, Irving, Linn, Lost Creek, Renfrew, Thayer and Villard glaciers estimates were each within roughly $0.15 \mathrm{~km}^{2}$ of Hodges calculation. Ten glaciers that I estimated for 1925 , have larger areas than there calculated by Hodge's areas, with Prouty Glacier have the largest difference, $1.01 \mathrm{~km}^{2}$. 
Table 17. Areas and difference $\left(\mathrm{km}^{2}\right)$ of the 15 major glaciers from Hodge (1925) and calculated areas for 1925 using Collier as a reference.

\begin{tabular}{|c|c|c|c|}
\hline Glacier & $\begin{array}{c}1925 \text { Hodge } \\
\text { Area }\end{array}$ & $\begin{array}{c}1925 \text { Calculated } \\
\text { Area }\end{array}$ & Difference \\
\hline Carver & 0.618 & $0.902 \pm 0.071$ & 0.284 \\
\hline Clark & 0.156 & $0.372 \pm 0.081$ & 0.216 \\
\hline Collier & 1.789 & $1.789 \pm 0.064$ & 0.000 \\
\hline Diller & 0.784 & $0.930 \pm 0.209$ & 0.146 \\
\hline Eugene & 0.401 & $0.255 \pm 0.035$ & -0.146 \\
\hline Hayden & 0.931 & $0.967 \pm 0.086$ & 0.036 \\
\hline Irving & 0.249 & $0.372 \pm 0.077$ & 0.123 \\
\hline Lewis & 0.108 & $0.771 \pm 0.114$ & 0.663 \\
\hline Linn & 0.160 & $0.230 \pm 0.041$ & 0.07 \\
\hline Lost Creek & 0.759 & $0.610 \pm 0.007$ & -0.149 \\
\hline Prouty & 0.666 & $1.673 \pm 0.223$ & 1.007 \\
\hline Renfrew & 0.748 & $0.625 \pm 0.001$ & -0.123 \\
\hline Skinner & 0.383 & $0.610 \pm 0.067$ & 0.227 \\
\hline Thayer & 0.227 & $0.208 \pm 0.036$ & -0.019 \\
\hline Villard & 0.082 & $0.223 \pm 0.063$ & 0.141 \\
\hline Total & 8.06 & $10.5 \pm 0.385$ & 2.48 \\
\hline
\end{tabular}

Without direct measurements from aerial photographs, large differences for a few glaciers, and lack of information on Hodge's collection methods, I trust my estimations more.

\section{Discussion and Conclusions}

The glaciers and perennial snowfields on the Three Sisters have lost area over the period of $\sim 1900-2003$. Decadal changes were synchronous, with rapid retreat, advance/stabilization, and continued slower retreat. The greatest area loss occurred between LIA ( 1900) to $1949\left(8.00 \pm 2.33 \mathrm{~km}^{2}\right)$. Glaciers and perennial snowfields generally advanced in the period 1949-1990. For the period 1949-2003 the glaciers and perennial snowfields that changed significantly (relative uncertainty $<1$ ) lost area -1.914 $\pm 0.097 \mathrm{~km}^{2}(21 \%)$. Longer time periods exhibited more significant changes than shorter time periods. In general, smaller glaciers lost larger fractions of their area and showed 
more variability. Overall, time periods showed statistically significant change over the study period. The variability in the smaller glaciers with larger uncertainty masked the change that is taking place.

The 15 named glaciers lost $6.693 \pm 0.439 \mathrm{~km}^{2}(54 \%)$ of their area from $\sim 1900-$ 2003 , with an average loss for named glaciers of $0.404 \mathrm{~km}^{2}$, which is similar to area changes across the PNW. Thayer Glacier changed the least, $-0.129 \pm 0.046 \mathrm{~km}^{2}(-53.1 \%)$, and the largest change was at Collier, $-1.36 \pm 0.177 \mathrm{~km}^{2}(-63.1 \%)$. The area change for the named glaciers was always significant even with glaciers with smaller areas. Smaller glaciers are still observed with significant change as compared to the smaller features of perennial snow.

The change of the 15 named glaciers is consistent with other studies in the American West and Western Canada. Glaciers in the Sierra Nevada have shown a 55\% decrease in area between 1903 and 2004 (Basagic and Fountain, 2011), and glaciers in Rocky Mountain National Park have declined by 40\% from 1909-2004 (Hoffman et al., 2007). To the north, glaciers in the North Cascades including Mt. Baker have decreased by $56 \%$ from 1900-2009 (Dick, 2013), glaciers on Rainier have declined by $22 \%$ from 1913-1994 (Nylen, 2001), glaciers on Adams have declined by 49\% from 1904-2006 (Sitts el al., 2010) and on Hood glaciers have declined by 40\% from 1909-2004 (Jackson and Fountain, 2007).

Topography has no demonstrated effect on the magnitude of glacier change. Perhaps a combination of variables has major effects on area change, as shown by Basagic and Fountain (2011) and Dick (2013). However, glaciers with greater elevation 
difference showed less area change. This suggests that there is some relationship between glaciers with higher elevation ranges (which is related to maximum elevations) and less area change.

Rock debris cover on glacier surfaces increased by $0.681 \pm 0.006 \mathrm{~km}^{2}(64 \%)$ from 1949 to 2003 with the greatest increase occurring between 1957 and 1990, $0.46 \pm 0.012$ $\mathrm{km}^{2}$. This corresponds with a positive but not significant correlation between the rate of area change and debris cover. Debris cover could be insulating the glaciers enough to slow down melting rates. This may contribute to observed area changes over the last century. Prior to 1957 glaciers deceased rapidly and had little to no rock debris cover and since then, as rock debris cover has increased, their rate of change has decreased. Collier Glacier is a relatively good index glacier for the Three Sisters because the magnitude of area changes is roughly similar to the other glaciers in time periods with data. Its area change was used to interpolate area changes for the other 14 named glaciers for 1925 and 1937. This estimated total area for $1925\left(10.54 \pm 0.385 \mathrm{~km}^{2}\right)$ is larger than then the total area calculated by Hodge (1925) $\left(8.06 \mathrm{~km}^{2}\right)$ (Table 17). Without direct measurements from aerial photographs, large differences for a few glaciers, and lack of information on Hodge's collection methods, I trust my estimations more.

When examining how glaciers have been changing over time, area change is one characteristic to investigate. In the next chapter I will be exploring how the volume of 15 named glaciers has been changing in order to get a better idea of how and what factors have been affect the glaciers on the Three Sisters. 


\section{Chapter Four - Volume Change}

\section{Introduction}

The purpose of this chapter is to examine the volume change of the 15 named

glaciers, presented in Chapter 3. I chose these glaciers because they have the most extensive record and well defined boundaries of all the glacier and perennial snowfields on the Three Sisters. I used aerial photography, digital elevations models (DEMs), and lidar data to reconstruct the surface topography from which glacier volume change is estimated.

\section{Methods}

Volume change was estimated for three time periods, 1957-1990, 1990-2010, and 1957-2010 because the DEMs were of good quality. The DEMs created from the 1949 and 1957 aerial photographs were of poor quality due to low image resolution, image distortion, and low textural resolution as previously explained. A comparison of my DEM from 1957 and the NED DEM created from the same imagery revealed that 1957 NED was of better quality as explained in Chapter 2. Elevation of each cell in one DEM was subtracted from the same cell location in the next DEM, and the cells were summed for volume change. The 1957 and 1990 DEMs had the same cell size of $10 \mathrm{~m}$ whereas the 2010 lidar-derived DEM had a cell size of $1 \mathrm{~m}$. The 2010 lidar DEM was coarsened to 10 meters using a bilinear resampling in ArcGIS 10.1. To insure that each raster cell exactly overlaid the same cell in another DEM, each DEM was 'snapped' to the 1957 DEM. Because the glacier area changes over time, to derive the volume 
change, the largest possible glacier boundary was defined by the intersection of the 3 glacier extents 1957, 1990, and 2003. To assess uncertainty the region was divided into control zones and glacier areas (Figure 20 and Figure 21).

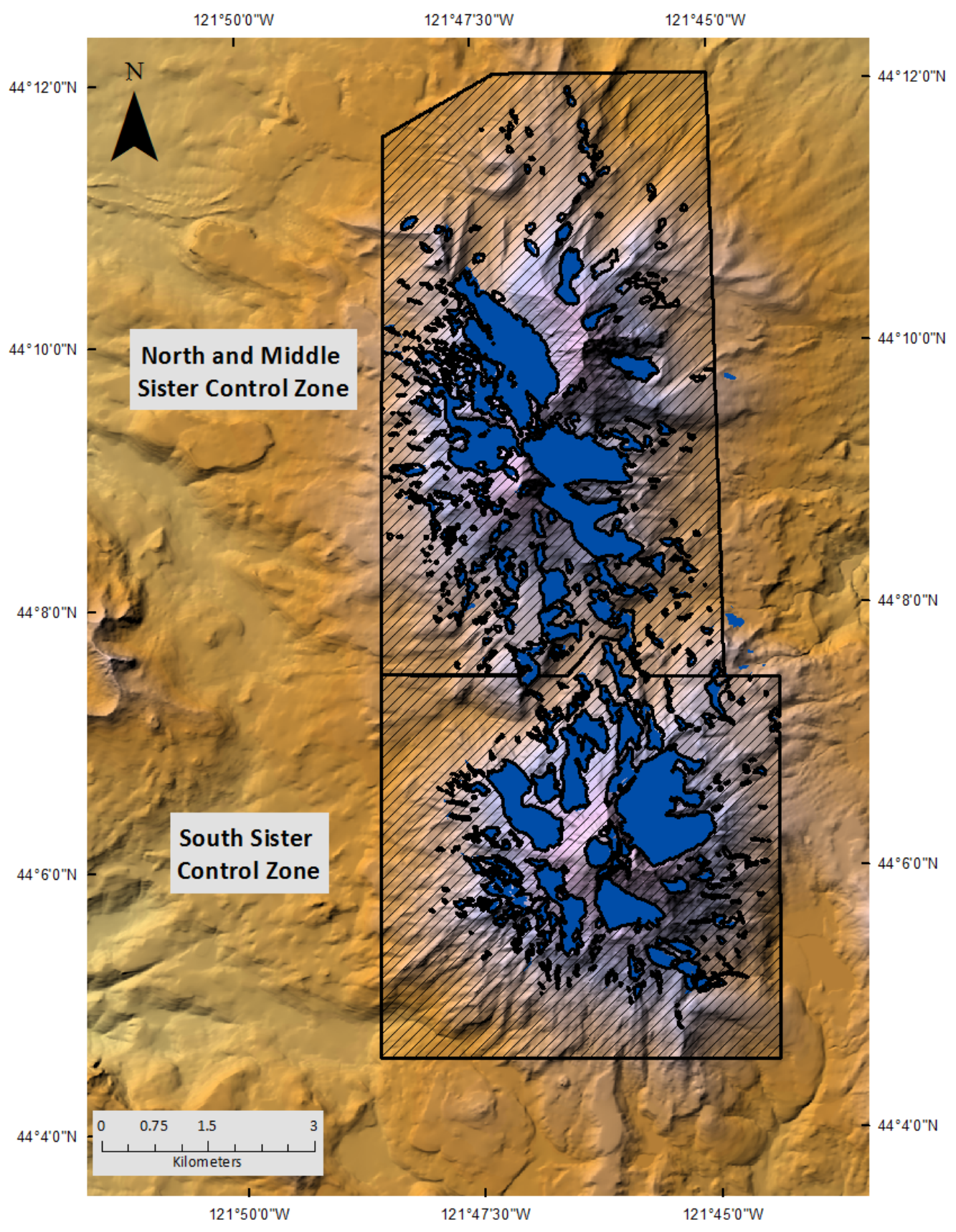

Figure 20. Locations of the control zones (hatched marked zones) for the volume change analysis used for 1957-2010. The blue regions are the glacier and perennial snowfield extents in 1957. Map is in WGS 84 UTM Zone 10. 
The control zones are regions free of snow and ice and the surface elevation is presumed constant over time. Different control zones for 1957-2010 (used for 19572010) and 1990-2010 (used for 1957-1990 and 1990-2010) were needed because the spatial extent of DEM in 1990 was smaller than those in 1957 and 2010 resulting in smaller control areas.

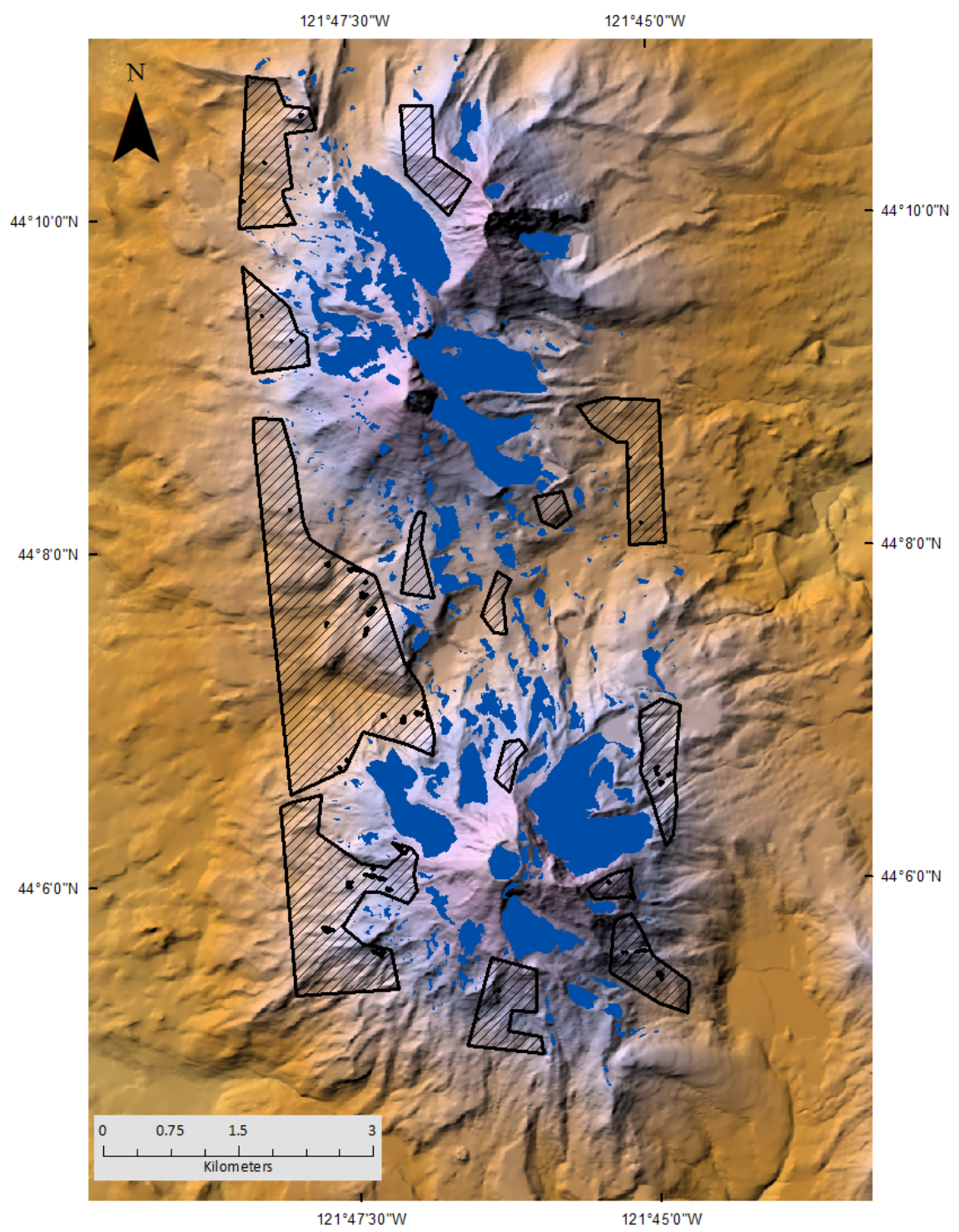

Figure 21. Locations of the control zones (hatched) for the volume change for 1957-1990 and 1990-2010. These control zones are free of snow and ice. The blue regions are the glacier and perennial snowfield extents in 1990. Map is in WGS 84 UTM Zone 10. 
Differences in the elevation of the control zones between DEMs were used as the uncertainty for the glacier elevation change. Following Zhang et al. (2005), the root mean square error (RMSE) of apparent elevation change in the control zones is calculated and divided by the RMSE of the glacier surface change yielding a fraction of change that is uncertain.

Because of the steep slopes encountered in glacial terrain I binned the control zones and ice-covered areas according to ten degrees slope bins. I assumed that horizontal surfaces will have a smaller uncertainty than steeply sloping surfaces. This rests on the notion that small shifts in the horizontal georeferencing of the DEMs produce larger vertical differences on steeper slopes.

The younger DEM was subtracted from the older DEM (i.e. 2010 subtracted from 1957) producing a raster of differenced elevations (ArcGIS 10.1), where negative values represent elevation loss and positive values represent elevation gain. The differenced elevations were categorized according to slope data and binned in $10^{\circ}$ increments for both the control and ice-covered areas. The total volume change within each slope bin for either the ice-covered area or control zone is,

$$
\Delta V_{j}=A \sum_{i=1}^{n} \Delta Z_{i j}
$$

where $n$ is the number of cells within a slope bin $j$ within the glacier perimeter, $A$ is the area of a cell, and $\Delta Z_{i}$ is the difference in elevation for each cell with in bin $j$. These volume change values were summed across all, $\mathrm{m}$, bins to estimate the total volume change for a glacier, 


$$
\Delta V=\sum_{j=1}^{m} \Delta V_{j}
$$

To calculate uncertainty of the volume change the root mean square error was calculated for each glacier slope bin in the control zone,

$$
R_{j}=\sqrt{\frac{\sum_{i=1}^{n}\left(\Delta Z_{i j}\right)^{2}}{n}}
$$

$R_{j}$ is also calculated for the change in elevation of the glacier surface. The uncertainty of the volume change for each slope bin is a fractional uncertainty of the RMSE for the control zones $\left(R_{c}\right)$ and glacier area $\left(R_{g}\right)$ derived from (10) which is $F$,

$$
F=\frac{R_{c}}{R_{g}}
$$

The uncertainty, $U$, of the volume change within each slope bin is,

$$
U= \pm \frac{|\Delta V| * F}{2}
$$

The total volume uncertainty across a glacier area is the root sum of squares across all slope bins.

\section{Results}

Three of the original five DEMs were deemed to be of ample quality to use for the volume change calculations; 1957 NED, 1990, and 2010. Visual inspection of the differenced 1957 and 2010 DEMs showed differences in the control zones around South Sister were greater than on North \& Middle Sisters. As a result, the control zones on South Sister were applied to only to South Sister named glaciers and the control zones for North \& Middle Sisters. No similar pattern was observed for 1957-1990 and 19902010 differenced DEMs. Uncertainties ranged from 4-6 m, in $10^{\circ}$ slope bins, to $21-28 \mathrm{~m}$ $\mathrm{m}$ in $80^{\circ}$ slope bins, as expected (Figure 22; Table 18 ). 

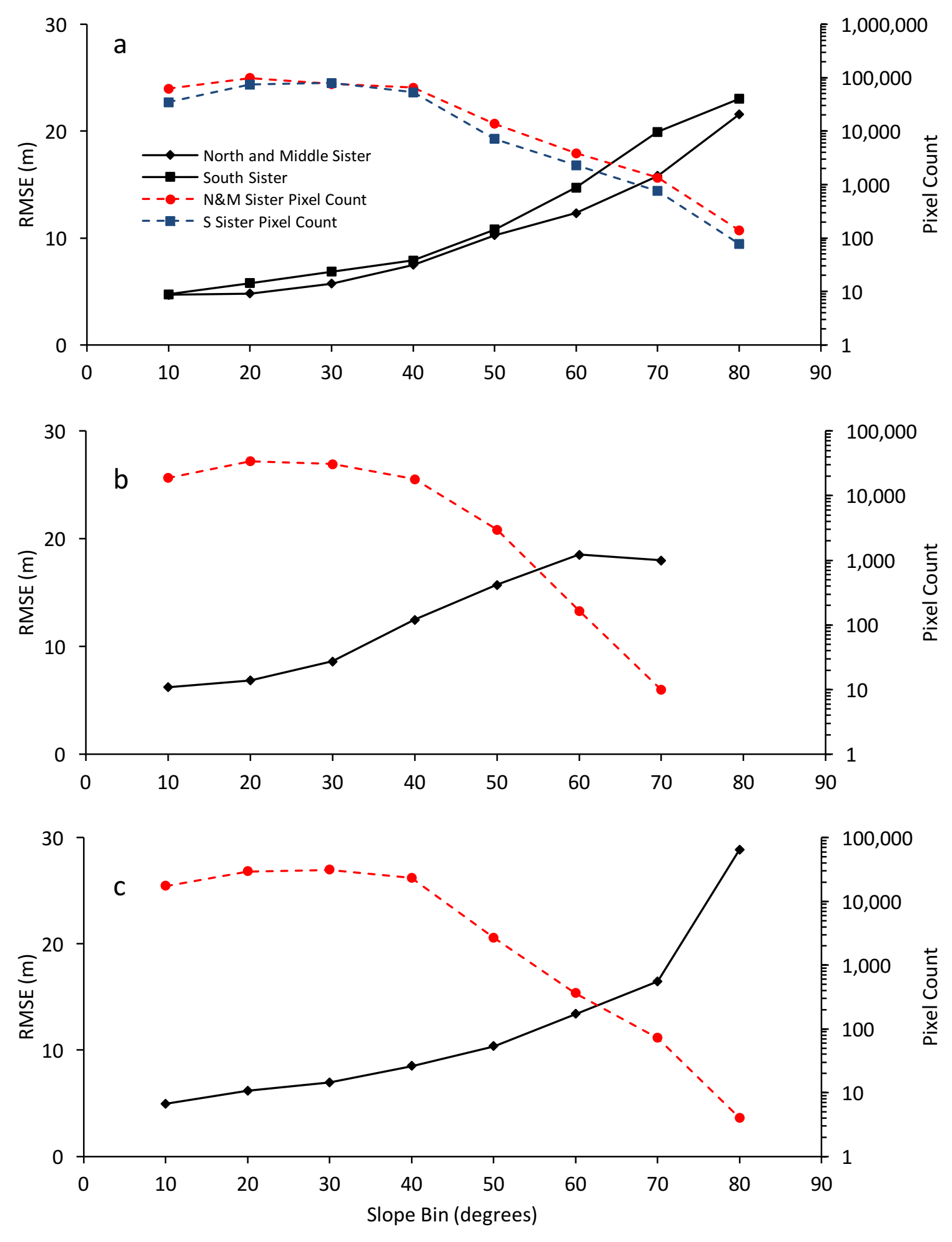

Figure 22. Root mean square error (RMSE) uncertainty (black) and pixel count (blue and red) for a) 19572010 North \& Middle and South Sisters, b) 1957-1990, c) 1990-2010 binned by slope shows a nonlinear increase of uncertainty as the slope increases. The value of each bin percent range is the maximum of that grouping. 
Table 18. Root mean square error (RMSE) and pixel count per slope bin from the uncertainty estimates for the surface change from 1957-2010, 1957-1990, and 1990-2010.

\begin{tabular}{|c|c|c|c|c|c|c|c|c|}
\hline \multirow[b]{3}{*}{ Slope } & \multicolumn{4}{|c|}{$1957-2010$} & \multicolumn{2}{|c|}{ 1957-1990 } & \multicolumn{2}{|c|}{$1990-2010$} \\
\hline & \multicolumn{2}{|c|}{ North \& Middle Sisters } & \multicolumn{2}{|c|}{ South Sister } & \multirow[b]{2}{*}{ RMSE } & \multirow{2}{*}{$\begin{array}{l}\text { Pixel } \\
\text { Count }\end{array}$} & \multirow[b]{2}{*}{ RMSE } & \multirow[b]{2}{*}{ Pixel Count } \\
\hline & RMSE & Pixel Count & RMSE & Pixel Count & & & & \\
\hline 10 & 4.7 & 62,400 & 4.7 & 34,692 & 6.2 & 18,760 & 4.9 & 17,432 \\
\hline 20 & 4.8 & 98,753 & 5.8 & 74,092 & 6.9 & 33,966 & 6.2 & 29,613 \\
\hline 30 & 5.7 & 76,383 & 6.8 & 79,830 & 8.6 & 30,817 & 6.9 & 31,217 \\
\hline 40 & 7.5 & 65,299 & 7.9 & 53,129 & 12.5 & 17,950 & 8.5 & 23,245 \\
\hline 50 & 10.3 & 13,637 & 10.8 & 7,166 & 15.7 & 2,988 & 10.3 & 2,674 \\
\hline 60 & 12.3 & 3,843 & 14.7 & 2,304 & 18.5 & 165 & 13.4 & 363 \\
\hline 70 & 15.8 & 1,337 & 19.9 & 759 & 18.0 & 10 & 16.5 & 72 \\
\hline 80 & 21.6 & 139 & 23.0 & 78 & & & 28.8 & 4 \\
\hline
\end{tabular}

Uncertainty increased nonlinearly with slope. The 80 degree slope bin showed an anomalous spike in 1990-2010 and the 70 degree slope bin showed an anomalous drop in 1957-1990 both of which may be due to small sample sizes.

All glaciers on the Three Sisters lost volume from 1957 to 2010 (Table 19, Figure 23) with a total loss of $72.0 \times 10^{6} \pm 2.87 \times 10^{6} \mathrm{~m}^{3}$, averaging $-8.9 \mathrm{~m}$ of surface lowering over all of the glaciers. The volume lost ranged from $-0.688 \times 10^{6} \pm 0.136 \times 10^{6} \mathrm{~m}^{3}$ at Villard Glacier to $-15.7 \times 10^{6} \pm 1.38 \times 10^{6} \mathrm{~m}^{3}$ at Collier Glacier. Specific volume change (total volume change divided by surface area) ranged from $-2.4 \pm 0.4 \mathrm{~m}$ at Irving Glacier to $-15.5 \pm 1.2 \mathrm{~m}$ at Diller Glacier. 
Table 19. Volume change estimates from 1957-2010 with specific volume change and percent uncertainty of volume change for the glaciers on the Three Sisters Volcanoes. South Sister glaciers names are italicized.

\begin{tabular}{lccc}
\hline \multicolumn{1}{c}{ Glacier } & Volume Change $\left(\mathbf{m}^{\mathbf{3}} \mathbf{\times} \mathbf{1 0}^{\mathbf{6}} \mathbf{)}\right.$ & $\begin{array}{c}\text { \% Uncertainty of } \\
\text { Volume Change }\end{array}$ & $\begin{array}{c}\text { Specific Volume } \\
\text { Change }(\mathbf{m})\end{array}$ \\
\hline Collier & $-15.68 \pm 1.380$ & $9 \%$ & $-14.3 \pm 1.3$ \\
Diller & $-10.62 \pm 0.800$ & $8 \%$ & $-15.5 \pm 1.2$ \\
Hayden & $-12.93 \pm 1.078$ & $8 \%$ & $-15.2 \pm 1.3$ \\
Irving & $-0.86 \pm 0.151$ & $17 \%$ & $-2.4 \pm 0.4$ \\
Linn & $-1.61 \pm 0.242$ & $15 \%$ & $-9.5 \pm 1.4$ \\
Renfrew & $-3.89 \pm 0.679$ & $17 \%$ & $-6.3 \pm 1.1$ \\
Thayer & $-2.08 \pm 0.236$ & $11 \%$ & $-13.5 \pm 1.5$ \\
Villard & $-0.69 \pm 0.136$ & $20 \%$ & $-11.9 \pm 2.3$ \\
Carver & $-1.48 \pm 0.384$ & $26 \%$ & $-4.7 \pm 1.2$ \\
Clark & $-1.42 \pm 0.396$ & $28 \%$ & $-4.1 \pm 1.1$ \\
Eugene & $-1.15 \pm 0.219$ & $19 \%$ & $-9.4 \pm 1.8$ \\
Lewis & $-2.79 \pm 0.654$ & $23 \%$ & $-6.5 \pm 1.5$ \\
Lost Creek & $-4.28 \pm 0.594$ & $14 \%$ & $-7.4 \pm 1.0$ \\
Prouty & $-9.44 \pm 1.582$ & $17 \%$ & $-7.3 \pm 1.2$ \\
Skinner & $-3.03 \pm 0.510$ & $17 \%$ & $-6.1 \pm 1.0$ \\
\hline Total & $-\mathbf{7 1 . 9 6} \pm \mathbf{2 . 8 6 7}$ & & \\
\hline
\end{tabular}

Parts of the Hayden, Diller, Lost Creek, Prouty, and Skinner glaciers showed thickening and advance of ice in their ablation zones (lower portion of the glacier) over this time period (1957-2010). These zones thickened between 20-40 m and are covered in rock debris. Debris covering the surface of the glaciers has increased from 1949-2003 as described in Chapter 3. Even with zones of thickening these glaciers still exhibited net volume loss. Overall, glaciers on South Sister lost less volume compared to North \& Middle Sister glaciers, $-23.6 \times 10^{6} \pm 2.08 \times 10^{6} \mathrm{~m}^{3}$ and $-48.4 \times 10^{6} \pm 1.97 \times 10^{6} \mathrm{~m}^{3}$. 


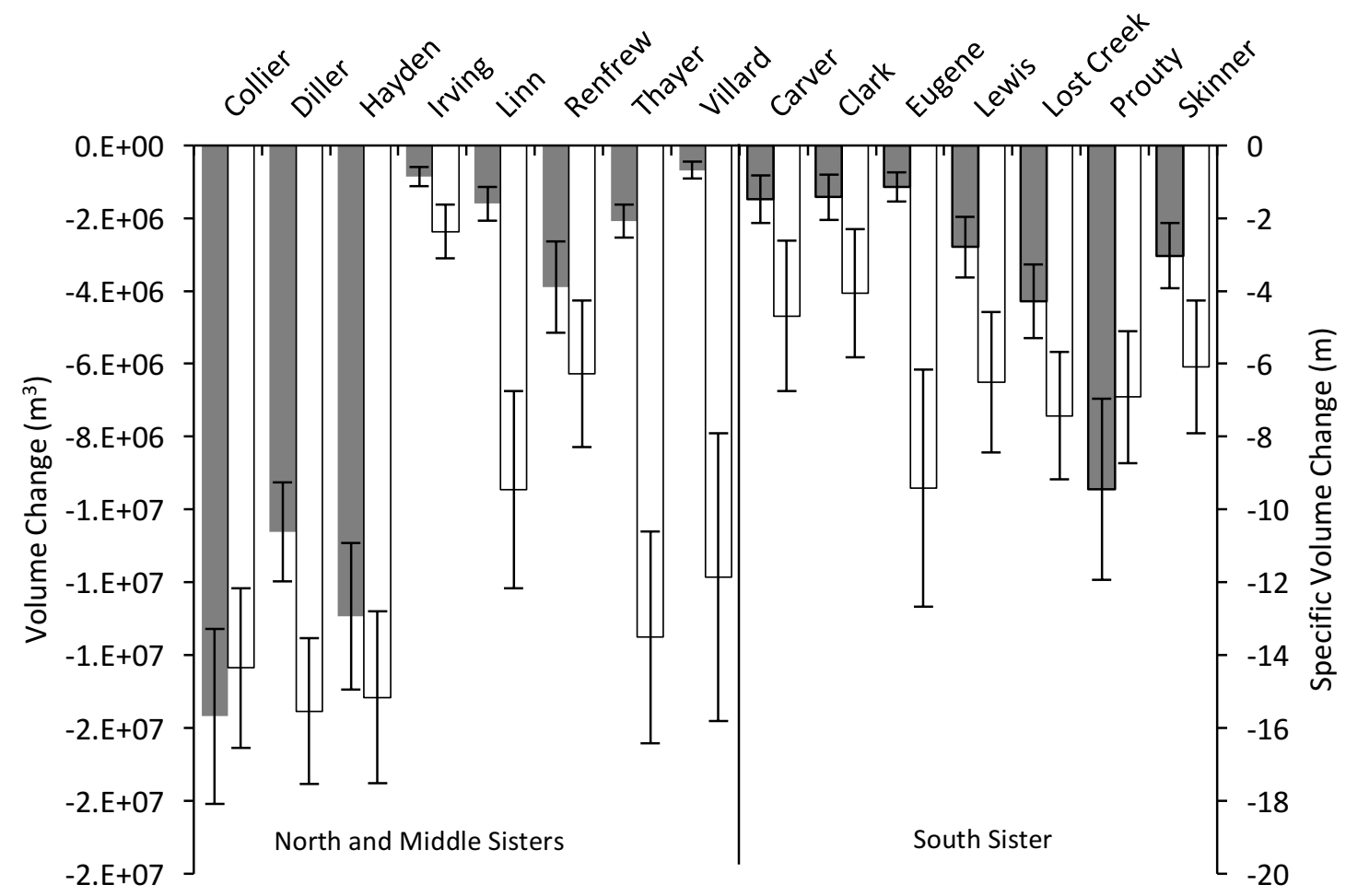

Figure 23. Total volume (filled bars) and specific volume change (open bars) from 1957-2010 shows the average thickness change average across the glaciers North \& Middle Sisters and South Sister glaciers.

From 1957 to 1990 all glaciers lost volume (Table 20, Figure 24) with a total loss of $-43.11 \times 10^{6} \pm 3.50 \times 10^{6} \mathrm{~m}^{3}(-5.7 \pm 2.5 \mathrm{~m})$, ranging from $-0.455 \times 10^{6} \pm 0.262 \times 10^{6} \mathrm{~m}^{3}$ $(-0.8 \pm 0.5 \mathrm{~m})$ at Clark Glacier to $-9.77 \times 10^{6} \pm 1.98 \times 10^{6} \mathrm{~m}^{3}(-9.0 \pm 2.8 \mathrm{~m})$ at Collier Glacier, with an average loss of $13.32 \times 10^{6} \mathrm{~m}^{3}$. This is an underestimate because the Thayer, Villard glaciers and 12\% of the Hayden Glacier had no data available for 1990. 
Table 20. Volume change estimates from 1957-1990 with specific volume change and percent uncertainty of volume change for the glaciers on the Three Sisters Volcanoes. The Thayer and Villard glaciers and roughly $12 \%$ of the Hayden* have no data for 1990 . South Sister glaciers names are italicized.

\begin{tabular}{lccc}
\hline \hline Glacier & Volume Change $\left(\mathbf{m}^{\mathbf{3}} \mathbf{\times} \mathbf{1 0}^{\mathbf{6}}\right)$ & $\begin{array}{c}\text { \% Uncertainty of } \\
\text { Volume Change }\end{array}$ & $\begin{array}{c}\text { Specific Volume } \\
\text { Change }(\mathbf{m})\end{array}$ \\
\hline Collier & $-9.765 \pm 1.980$ & $20 \%$ & $-9.0 \pm 1.8$ \\
Diller & $-3.590 \pm 0.723$ & $20 \%$ & $-5.4 \pm 1.1$ \\
Hayden* & $-6.509 \pm 1.266$ & $19 \%$ & $-7.8 \pm 1.5$ \\
Irving & $-0.450 \pm 0.253$ & $56 \%$ & $-1.3 \pm 0.7$ \\
Linn & $-0.661 \pm 0.290$ & $44 \%$ & $-4.7 \pm 2.1$ \\
Renfrew & $-0.455 \pm 0.157$ & $35 \%$ & $-0.8 \pm 0.3$ \\
Thayer & No Data & No Data & No Data \\
Villard & $-0.584 \pm 0.262$ & $45 \%$ & $-1.9 \pm 0.9$ \\
Carver & $-3.128 \pm 0.694$ & $22 \%$ & $-9.2 \pm 2.0$ \\
Clark & $-1.201 \pm 0.302$ & $25 \%$ & $-10.3 \pm 2.6$ \\
Eugene & $-1.465 \pm 0.648$ & $44 \%$ & $-3.5 \pm 1.5$ \\
Lewis & $-3.122 \pm 0.701$ & $22 \%$ & $-5.6 \pm 1.3$ \\
Lost Creek & $-8.609 \pm 1.997$ & $23 \%$ & $-6.7 \pm 1.5$ \\
Prouty & $-3.574 \pm 0.677$ & $19 \%$ & $-7.6 \pm 2.8$ \\
Skinner & $-43.11 \pm 3.495$ & & \\
\hline Total & & &
\end{tabular}

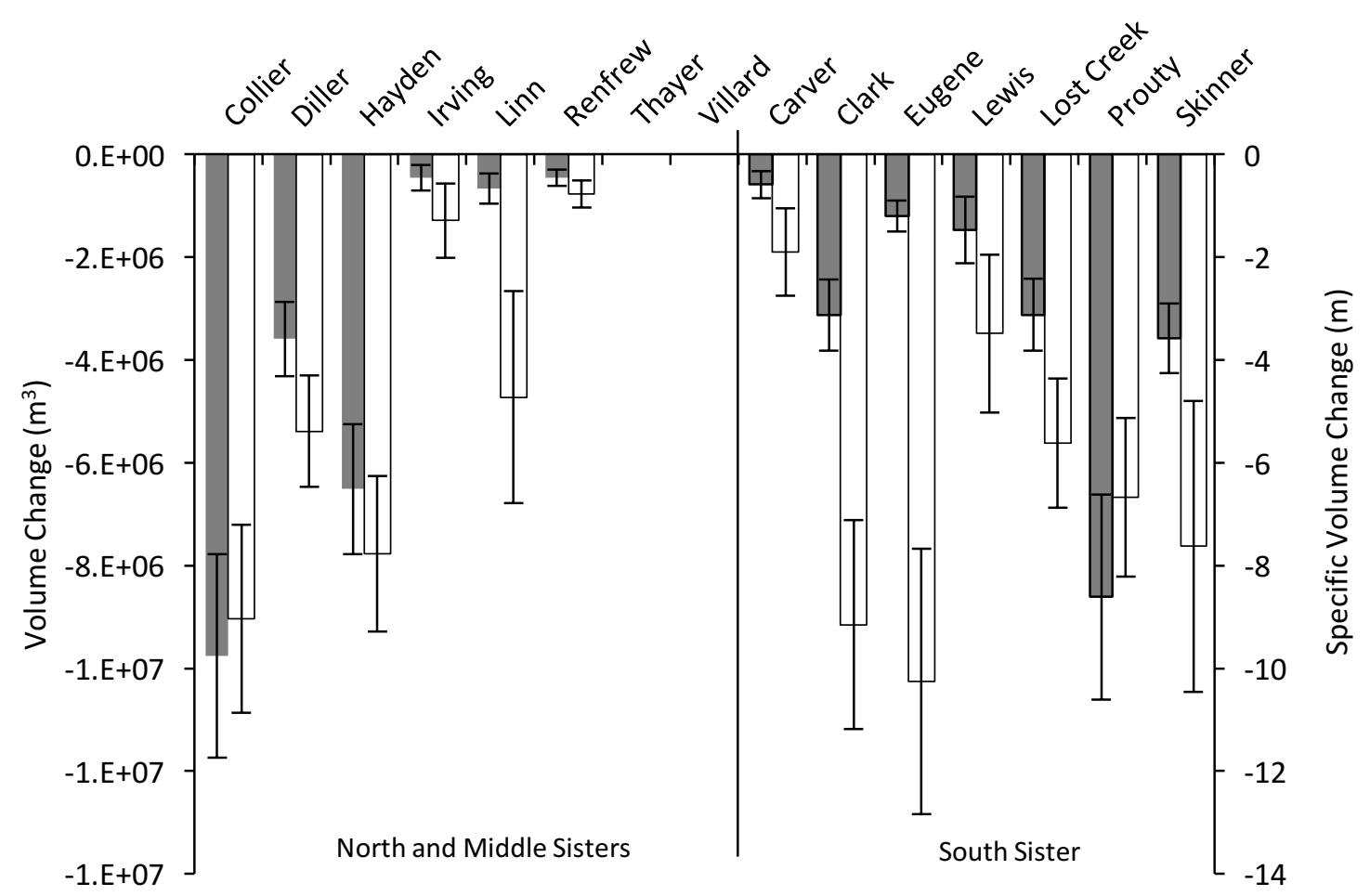

Figure 24. Total volume (filled bars) and specific volume change (open bars) from 1957-1990. In general the North \& Middle Sister glaciers show higher volume loss than South Sister glaciers. 
From 1990 to 2010 all the glaciers, except Clark and Skinner, lost volume (Table 21 , Figure 25) with a total loss of $25.19 \times 10^{6} \pm 2.30 \times 10^{6} \mathrm{~m}^{3}(-3.4 \pm 1.8 \mathrm{~m})$, ranging from a gain of $0.851 \times 10^{6} \pm 0.280 \times 10^{6} \mathrm{~m}^{3}(4.7 \pm 1.6 \mathrm{~m})$ at Clark Glacier to a loss of $-6.77 \times 10^{6}$ $\pm 1.00 \times 10^{6} \mathrm{~m}^{3}(-11.0 \pm 1.6 \mathrm{~m})$ at Diller Glacier, with an average loss of $1.94 \times 10^{6} \mathrm{~m}^{3}$. Again, these totaled values are an underestimate because the Thayer, Villard glaciers and $\sim 12 \%$ of the Hayden Glacier had no data available for 1990.

Table 21. Volume change estimates from 1990-2010 with specific volume change and percent uncertainty of volume change for the glaciers on the Three Sisters Volcanoes. The Thayer and Villard glaciers and roughly $12 \%$ of the Hayden* have no data for 1990 . South Sister glaciers names are italicized.

\begin{tabular}{lccc}
\hline Glacier & Volume Change $\left(\mathbf{m}^{\mathbf{3}} \mathbf{\times} \mathbf{1 0}^{\mathbf{6}}\right)$ & $\begin{array}{c}\text { \% Uncertainty of } \\
\text { Volume Change }\end{array}$ & $\begin{array}{c}\text { Specific Volume } \\
\text { Change }(\mathbf{m})\end{array}$ \\
\hline Collier & $-5.792 \pm 1.341$ & $23 \%$ & $-6.6 \pm 1.5$ \\
Diller & $-6.770 \pm 1.002$ & $15 \%$ & $-11.0 \pm 1.6$ \\
Hayden* & $-6.054 \pm 1.034$ & $17 \%$ & $-7.7 \pm 1.3$ \\
Irving & $-0.397 \pm 0.136$ & $34 \%$ & $-1.6 \pm 1.0$ \\
Linn & $-1.037 \pm 0.240$ & $23 \%$ & $-6.7 \pm 1.6$ \\
Renfrew & $-2.792 \pm 0.694$ & $25 \%$ & $-5.6 \pm 1.4$ \\
Thayer & No Data & No Data & No Data \\
Villard & $-0.755 \pm 0.278$ & $37 \%$ & $-3.7 \pm 1.3$ \\
Carver & $0.851 \pm 0.280$ & $33 \%$ & $4.7 \pm 1.6$ \\
Clark & $-0.070 \pm 0.049$ & $70 \%$ & $-1.0 \pm 0.7$ \\
Eugene & $-1.421 \pm 0.426$ & $30 \%$ & $-4.1 \pm 1.2$ \\
Lewis & $-0.670 \pm 0.183$ & $27 \%$ & $-1.3 \pm 0.4$ \\
Lost Creek & $-0.881 \pm 0.624$ & $71 \%$ & $-0.7 \pm 0.5$ \\
Prouty & $0.587 \pm 0.273$ & $47 \%$ & $1.5 \pm 0.7$ \\
Skinner & $-\mathbf{2 5 . 1 9} \pm \mathbf{2 . 2 9 5}$ & & \\
\hline Total & & &
\end{tabular}




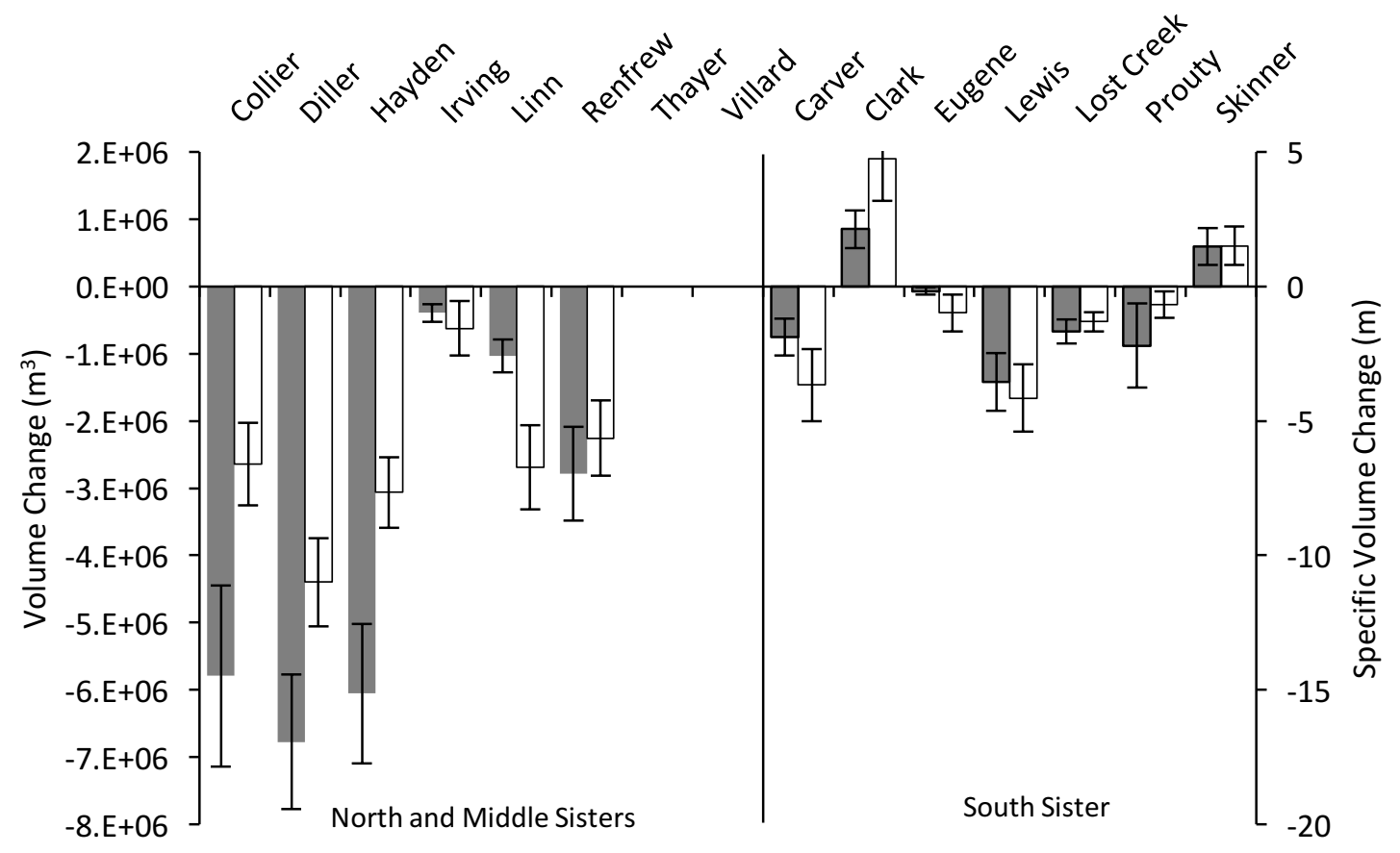

Figure 25. Total volume change and specific volume change from 1990-2010. In general the North \& Middle Sister glaciers (filled bars and hatched) show higher volume loss than South Sister glaciers (open bars and dots), which showed some total volume gain.

Pronounced thinning, typically 10 to $15 \mathrm{~m}$ across the glaciers and in some places $>40 \mathrm{~m}$, was observed on North \& Middle Sisters. The glaciers specific volume change for North \& Middle glaciers averaged -11.3 m as compared to South Sister glaciers, averaging $-6.5 \mathrm{~m}$. Even with parts of some glaciers thickening from 1990 to 2010, all of the 15 named glaciers lost elevation during the 1957-2010 period.

Volume loss was observed in both the ablation and accumulation zones on all glaciers (Figure 26 and Figure 27). On the North \& Middle Sisters, volume loss was observed in the accumulation zones of Collier, Diller, and Hayden glaciers. On the South Sister glaciers, significant lost was also observed in the accumulation zones of the glaciers; however it is not as pronounced. 


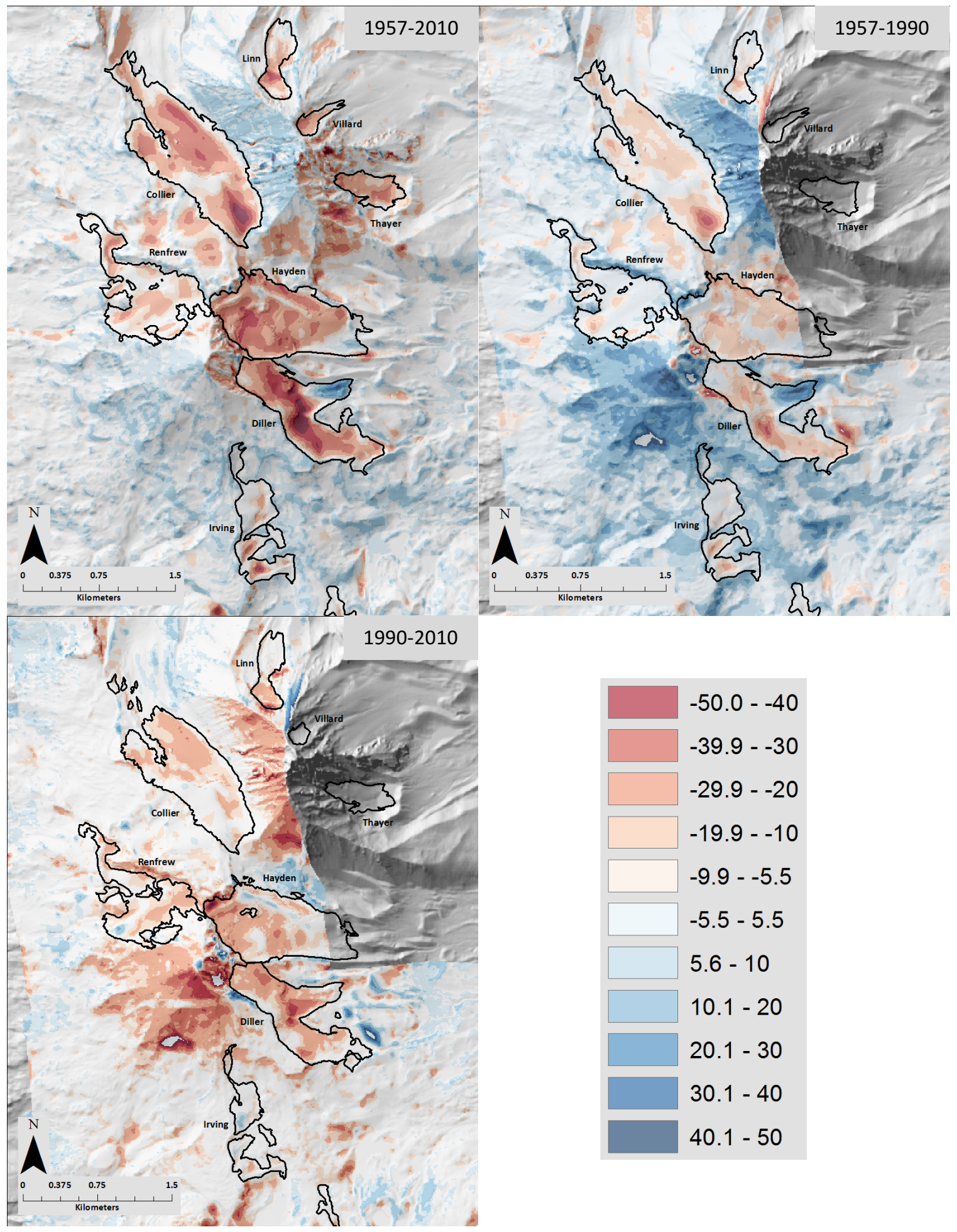

Figure 26. Difference maps showing the spatial distribution of elevation change $(\mathrm{m})$ from 1957-2010, 1957-1990, and 1990-2010 of the 15 named glaciers on North \& Middle Sister. Areas in red are volume loss and blue are volume gain. Glacier outlines, in black, are a combination of the outlines to encompass maximum possible area of the glacier. Grey shaded area is no data. Maps are in WGS 84 UTM Zone 10. 


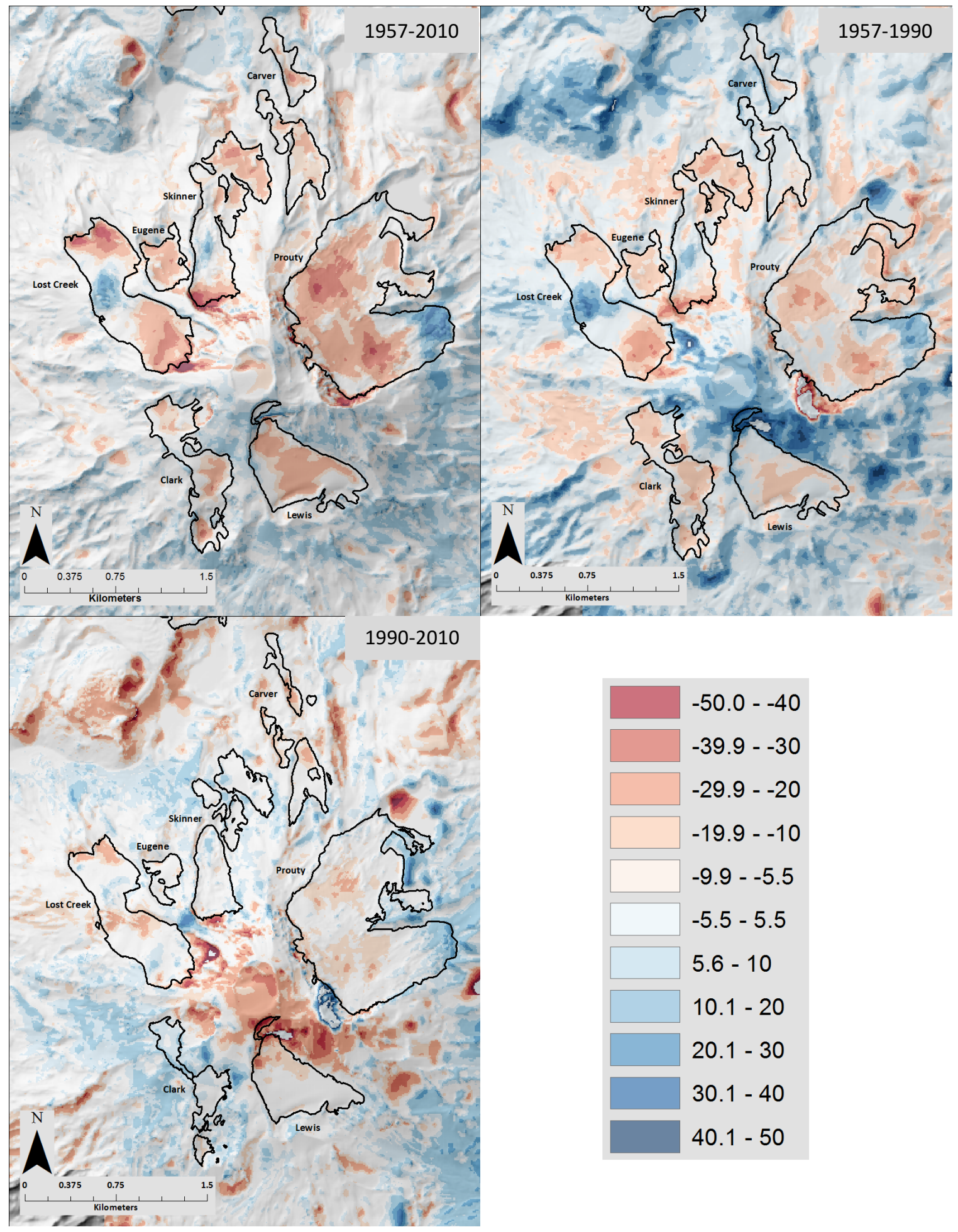

Figure 27. Maps showing the spatial distribution of elevation change $(\mathrm{m})$ of the 15 named glaciers on South Sister. Areas in red represent volume loss and colors in blue represent volume gain from 19572010, 1957-1990, and 1990-2010. Glacier outlines, in black, are a combination of the outlines to encompass maximum possible area of the glacier. Maps are in WGS 84 UTM Zone 10. 
(Figure 28). Overall, significant volume loss can be seen spatially across entire glaciers.

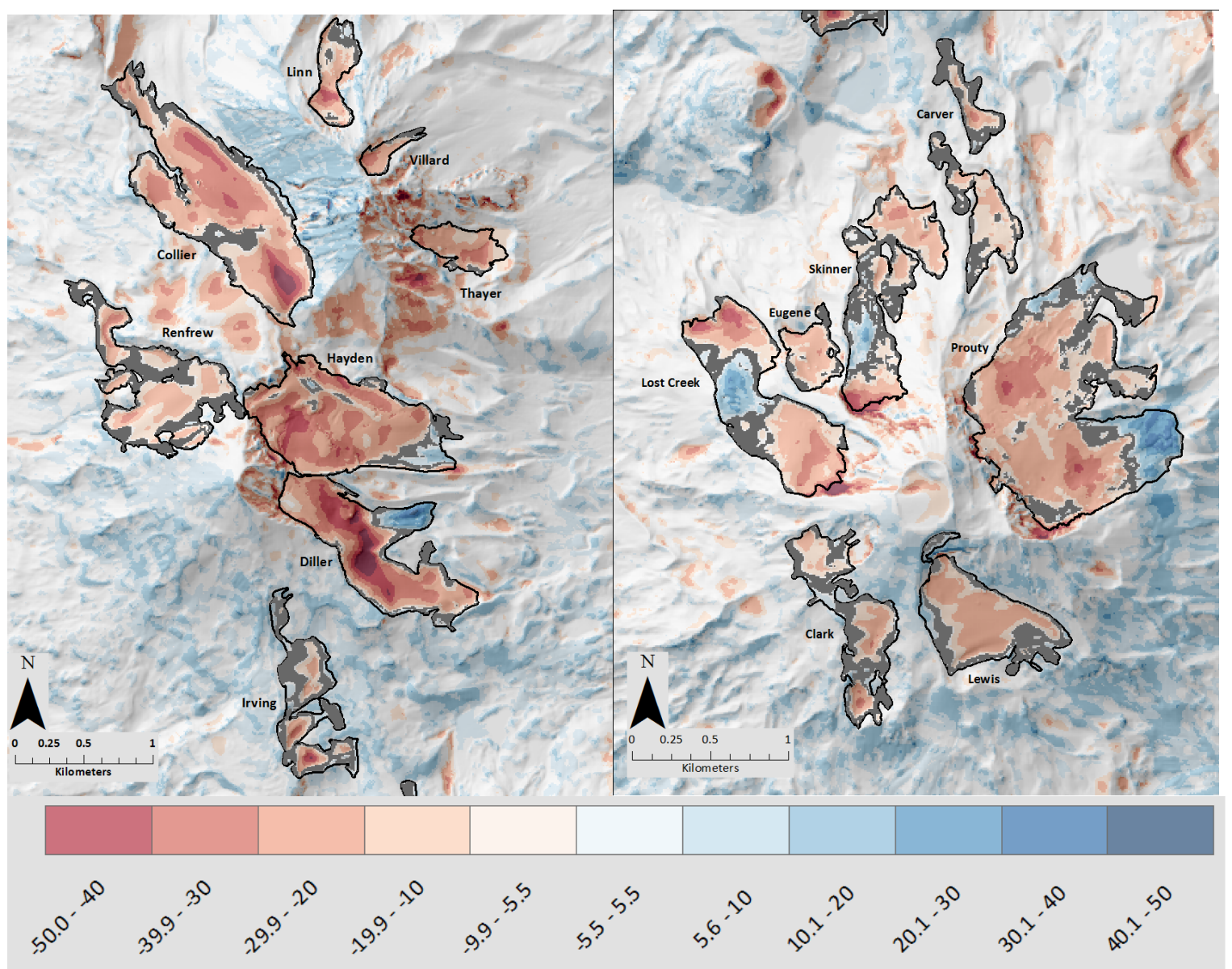

Figure 28. The spatial distribution of elevation change of the 15 named glaciers on the Three Sisters with statistically insignificant volume change zones in gray. Areas in red represent volume loss and colors in blue represent volume gain from 1957-2010. Glacier outlines, in black, are the largest of the outlines within those respective temporal ranges. Maps are in WGS 84 UTM Zone 10.

Finally, I examined the elevation change of unnamed perennial snowfield in the crater of South Sister. This perennial snowfield from 1957-2010 lost a total volume of $-0.537 \times 10^{6} \pm 0.164 \times 10^{6} \mathrm{~m}^{3}$ and dropped in surface elevation by $-4.82 \pm 2.59 \mathrm{~m}$. 


\section{Analysis}

To estimate the fraction of total ice volume lost on the Three Sisters since 1900 and 1957 I calculated the volume of the 15 named glaciers using a area volume scaling relationship (Chen and Ohmura, 1990; Bahr et al., 1997). The estimated total volume in 1900 is $255.0 \times 10^{6} \pm 6.77 \times 10^{6} \mathrm{~m}^{3}$ and in 1957 is $141.3 \times 10^{6} \pm 13.2 \times 10^{6} \mathrm{~m}^{3}$. The uncertainty was the difference between the calculated estimate using the two methods. As a result, the 15 named glaciers lost a total volume of $\sim 47 \%$ from $1900-1957$ (relative to 1990 ) and 53\% from $1957-2010$ (relative to 1957), 31\% from 1957-1990, and 18\% from 1990-2010 (relative to 1957). More loss occurred during 1957-1990 compared to 1990-2010, with a few exceptions, most notably, Diller Glacier. From 1957-1990 the Diller Glacier lost an average of $-5.4 \mathrm{~m}$ and from 1990-2010 it lost and -11.0 m.

Substantial local thinning was observed on both Collier and Diller glaciers. The Collier Glacier thinned by as much as $45-50 \mathrm{~m}$ from 1957-2010 in the accumulation zone above $2600 \mathrm{~m}$. The Diller Glacier lost up to $45-50 \mathrm{~m}$ of elevation near the middle of the glacier between $2400-2600 \mathrm{~m}$ (Figure 29). As a qualitative check on these thinning estimates I

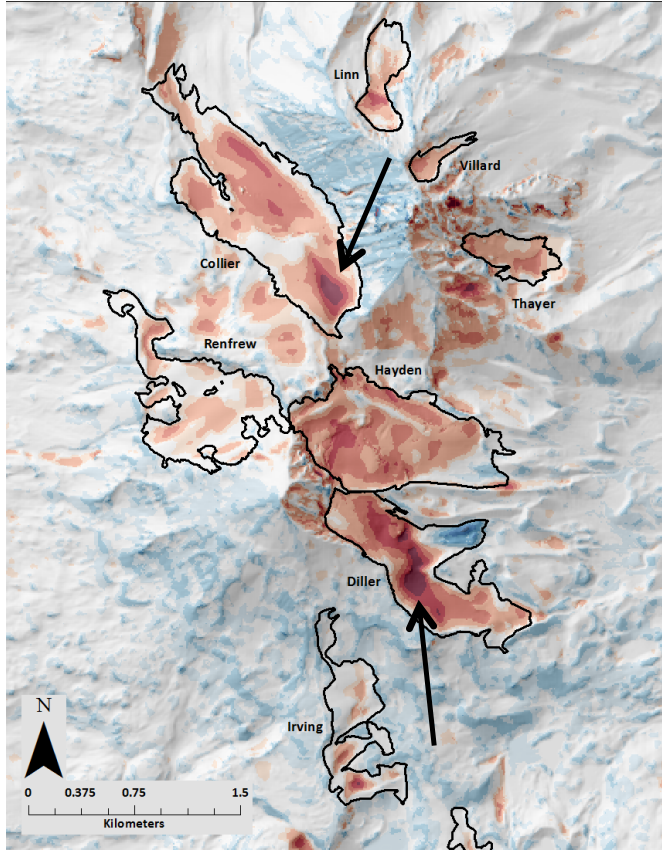

Figure 29. Map showing location of substantial thinning on the Collier and Diller glaciers from 1957-2010. Map is in WGS 84 UTM Zone 10. compared aerial and groundbased oblique photographs to determine if these changes could be observed. Photos showed outcrops were exposed more and visible thinning 
along glacier boundaries can be seen with observed loss in the ablation zone (Figure 30).

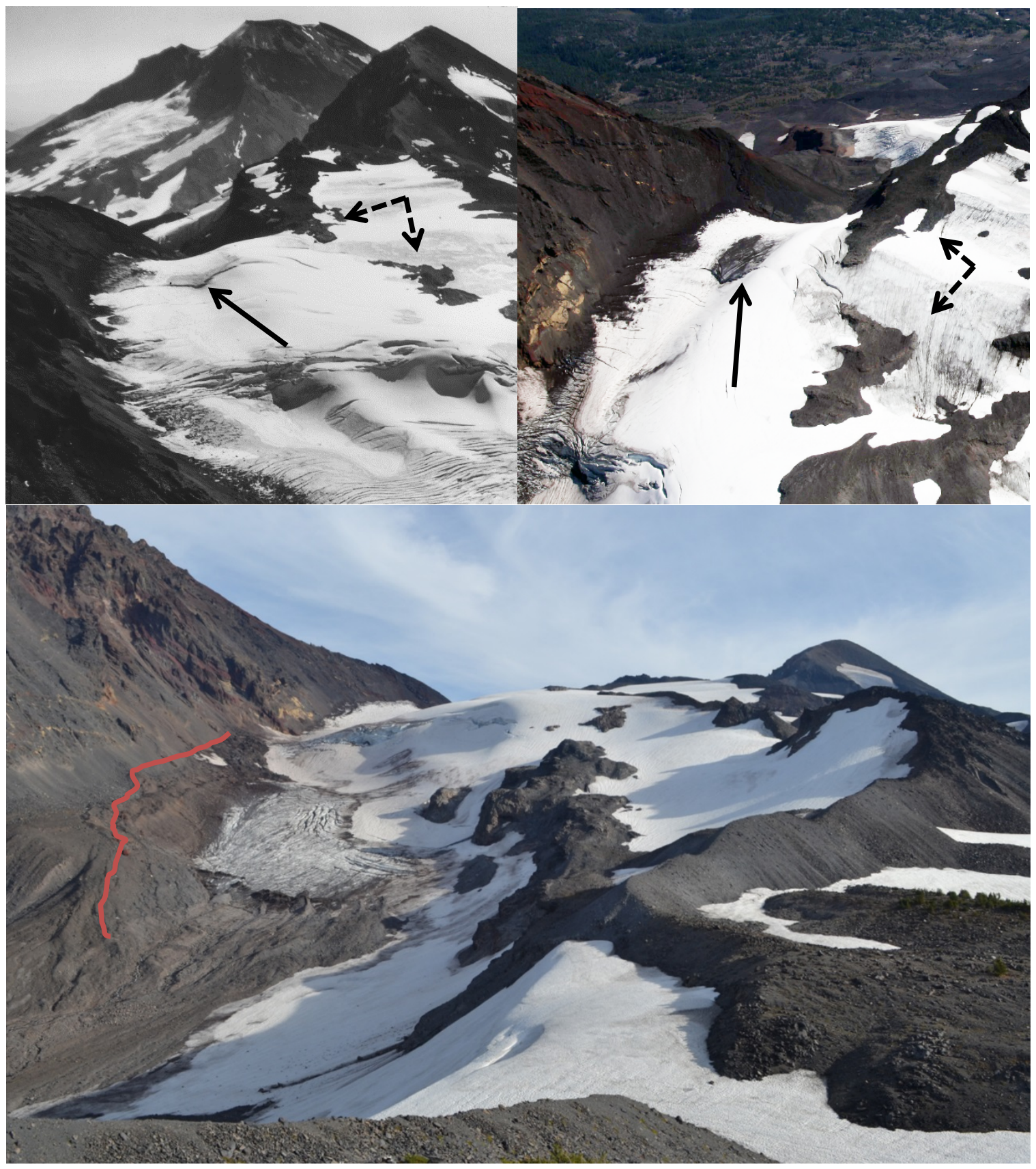

Figure 30. Comparison of the Collier Glacier from September 21, 1960 (Top left, photo taken by Austin Post) and August 24, 2007 (Top right, photo taken by John Scurlock). Based on the volume change calculation the glacier has lost up $45 \mathrm{~m}$ of surface elevation in the accumulation zone where the solid black arrows are pointing. Notice the exposure of bedrock within the glacier as the surface elevation has been dropped (dashed arrows). Bottom photo of the Collier Glacier showing the approximate location of the glacier boundary based on oblique aerial photos from around 1960 on a photo taken in September 28, 2012 (Justin Ohlschlager). Photo Sources: 1960 - University of Washington; 2007 - Portland State University and Mazamas. 
To examine whether topography has an influence I compared the variation of glacier loss (1957-2010) to the 1957 mean elevation, elevation difference, slope, and aspect. The results showed poor correlation and statistical insignificance with the exception to slope on South Sisters glaciers (Figure 31 and Figure 32).
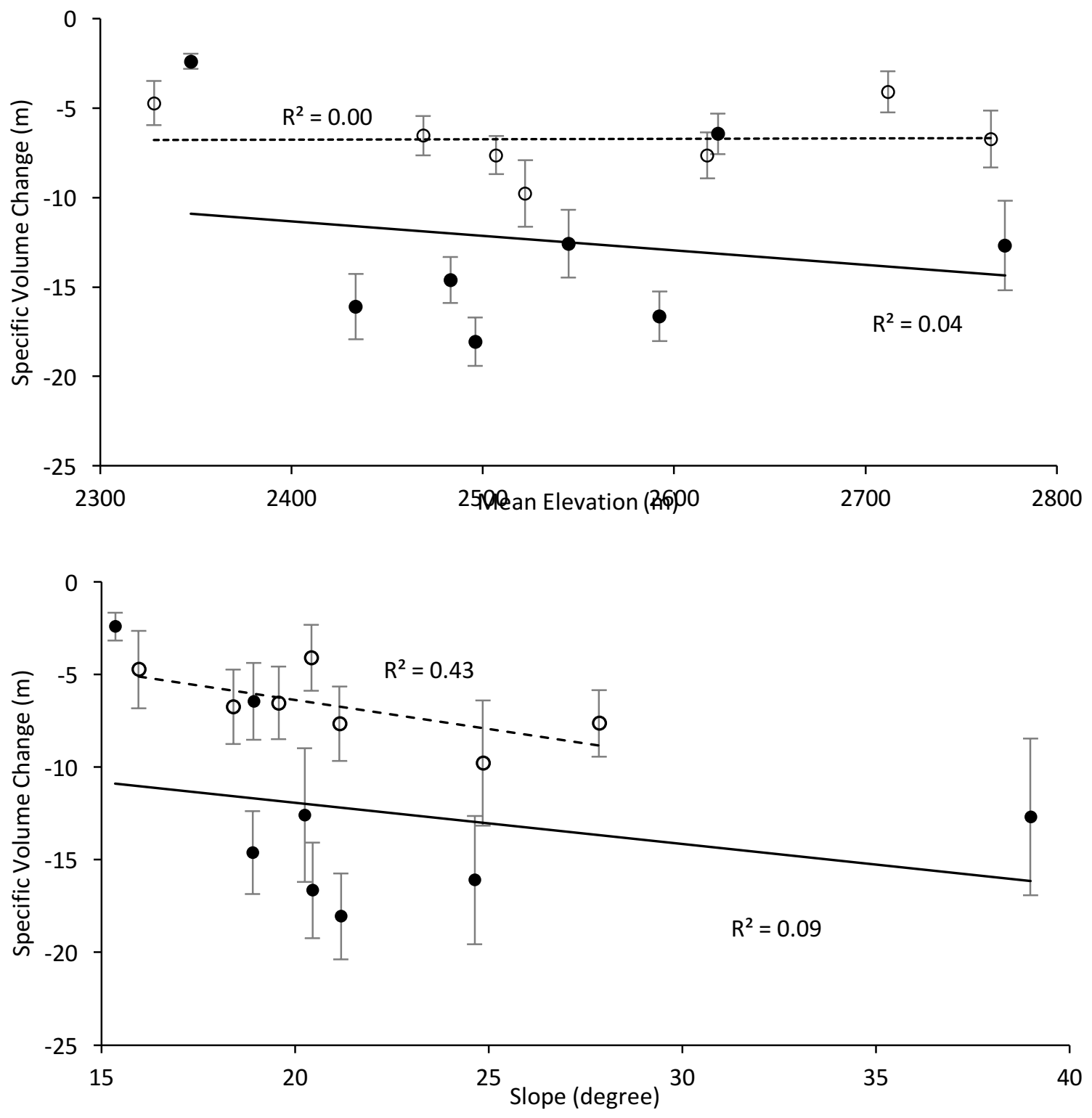

Figure 31. Specific volume change (1957-2010) as a function of average elevation and slope. The open circles and dash line are South Sister glaciers and the filled circles and solid line are North \& Middle Sisters glaciers. 
The best correlation was between the slope and volume change for the South

Sister glaciers, increased slope - greater loss $\left(r^{2}=0.43\right)$ but was not significant $(p<0.05)$.
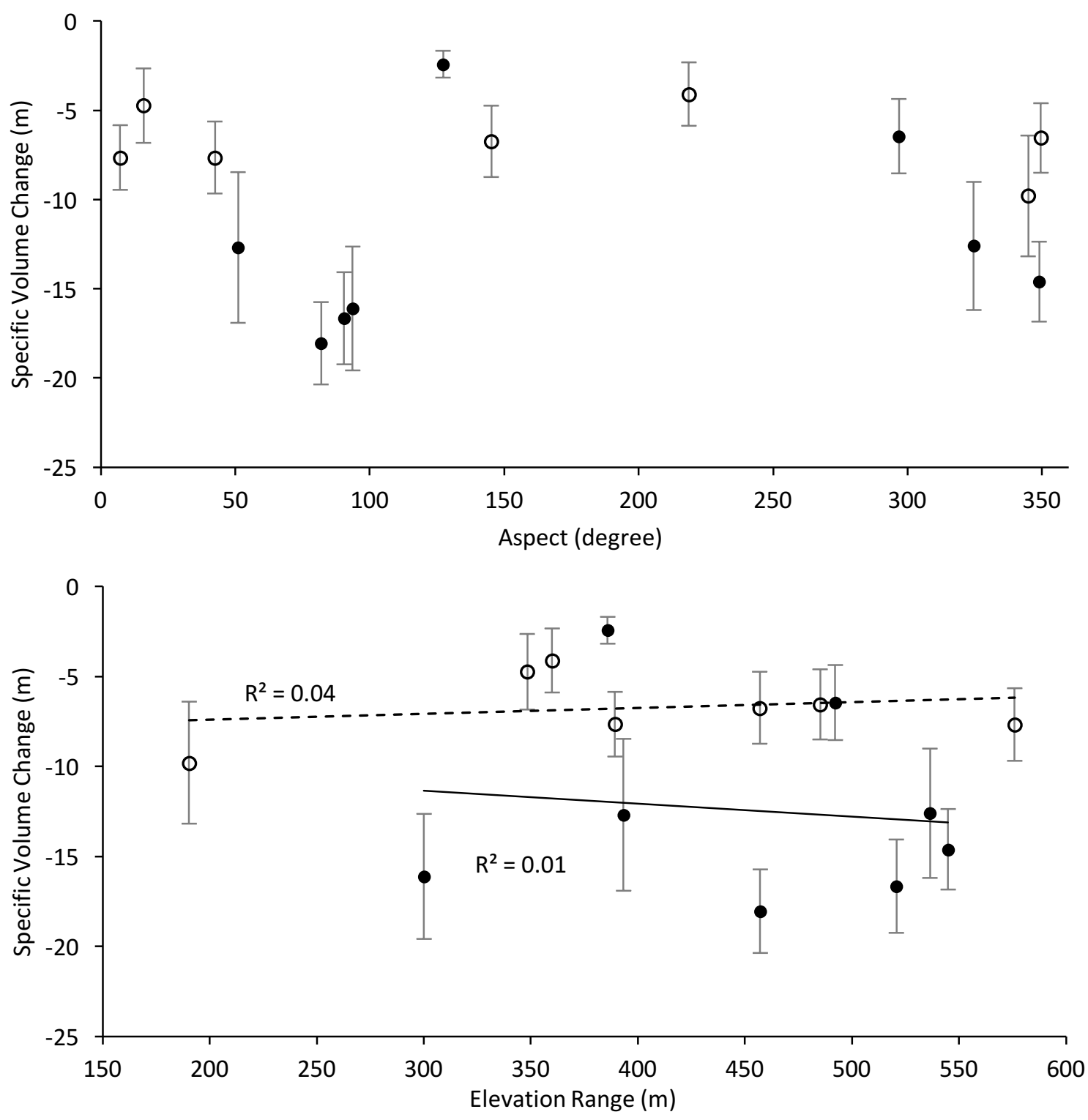

Figure 32. Specific volume change (1957-2010) as a function of average aspect and elevation difference. The open circles and dashed line are South Sister glaciers and the filled circles and solid line are North \& Middle Sisters glaciers.

When examining the plots for 1957-1990 and 1990-2010, no topographic variable showed correlation to volume change. Glaciers with a southerly aspect showed 
lower specific volume change as compared to other glaciers. This might be due to the fact that there is more ice in the northerly aspect, thus more ice to lose. Perhaps a combination of variables have a greater correlation on glacier volume change then just one variable alone.

To examine if the debris cover affects the volume change I plotted the specific volume change versus the debris cover percentage and with aspect (Figure 33). The specific volume change was not significantly correlated with debris cover, which differs from the correlation seen between the area change and debris cover.

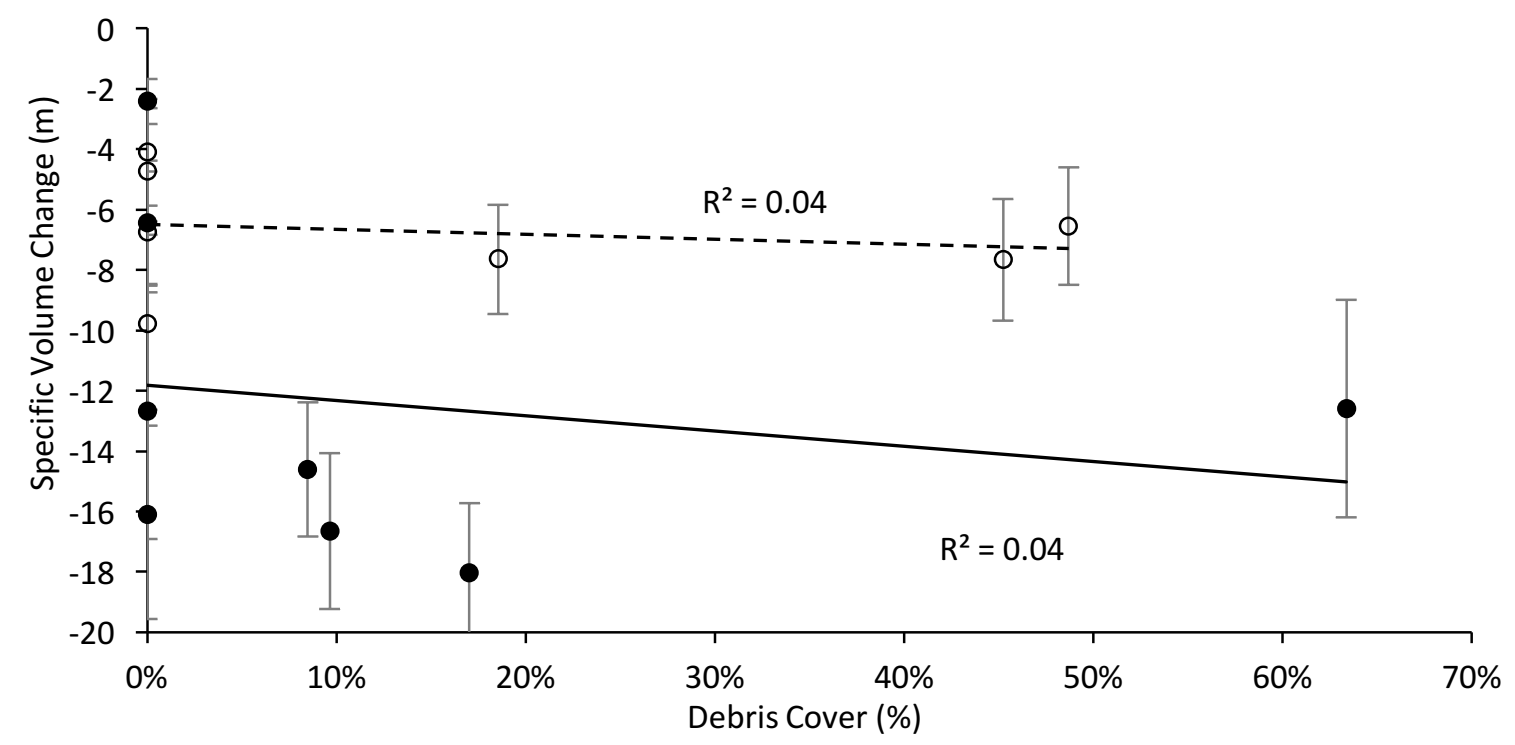

Figure 33. Specific volume change (1957-2010) as a function of debris cover. The open circles and dashed line are South Sister glaciers and the closed circles and solid line are North \& Middle Sisters glaciers.

Thickening zones on the Diller, Hayden, Lost Creek, Prouty, and Skinner glaciers are covered by rock debris which could be thick enough to insulate the ice, reducing ice melting, and promoting advance. However, not all debris-covered regions showed signs of thickening. Glaciers with debris cover faced between the NW to E directions with no 
debris on glaciers facing SE to W (via the south). This might be due to that larger glaciers (Collier, Diller, Hayden, Prouty) facing in these directions and eroding the mountains creating steep headwalls, and this eroded debris is being collected on their surfaces because of larger surface areas and lower slopes. The glaciers with debris cover on their surfaces are below these steep eroded headwalls with surfaces $>40^{\circ}$. The erosion of these headwalls contributed debris to the glaciers (Figure 34).

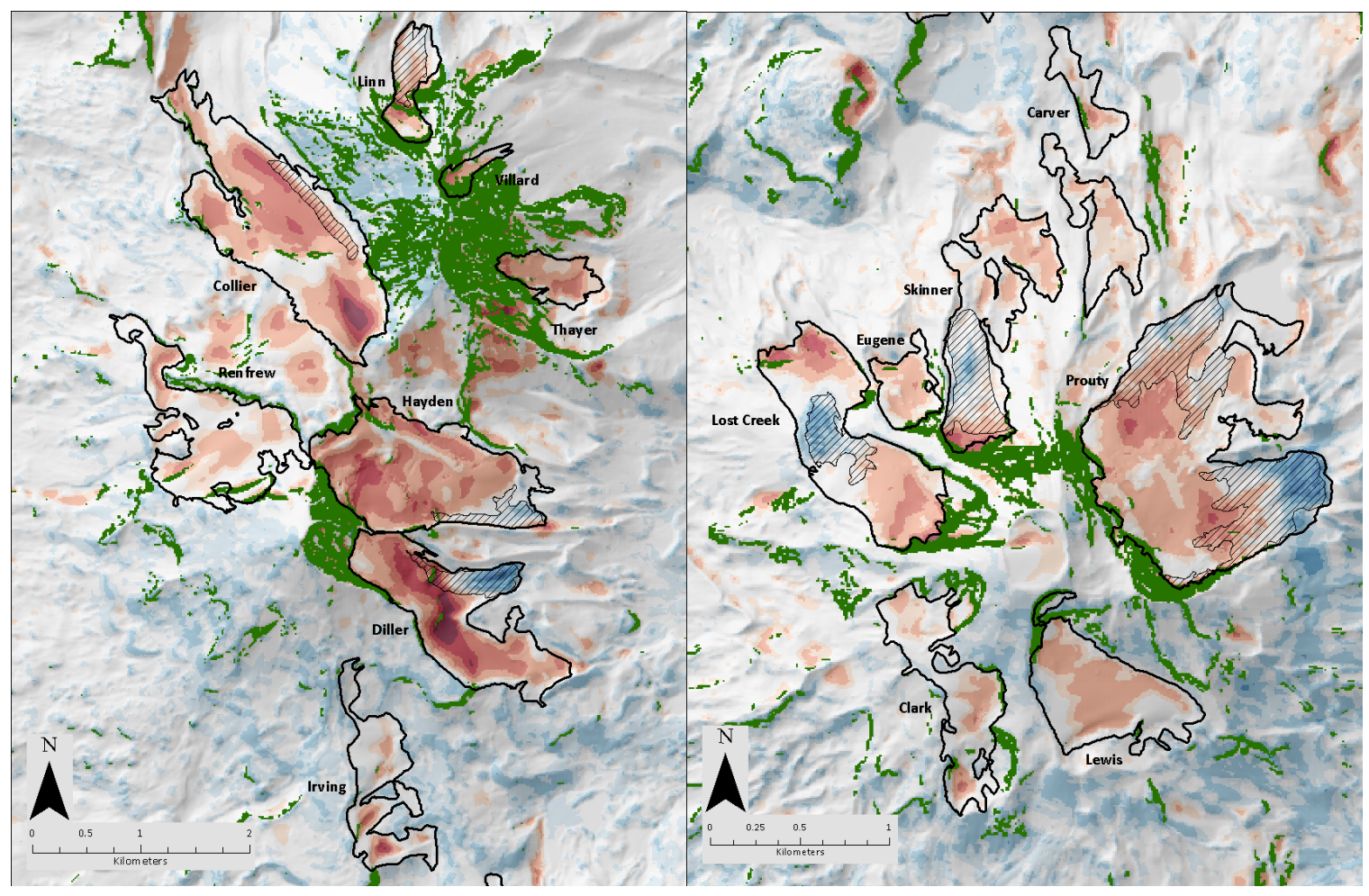

Figure 34. Maps showing the spatial distribution of elevation change of the 15 named glaciers on the Three Sisters with Slopes above $40^{\circ}$ green. Glacier outlines, in black and debris covered ice zones are the hatched marked areas. Map is in WGS 84 UTM Zone 10.

To examine if there is a relationship between volume change and area change I plotted the volume change versus the area change, from 1957-2010 (area change is from 1957-2003) (Figure 35). There was no observed relationship between the area change and volume change on South Sister. However, the glaciers on the North \& 
Middle Sisters revealed a slight correlation $\left(r^{2}=0.24\right)$ - it shows that with increasing area change the volume loss increased.

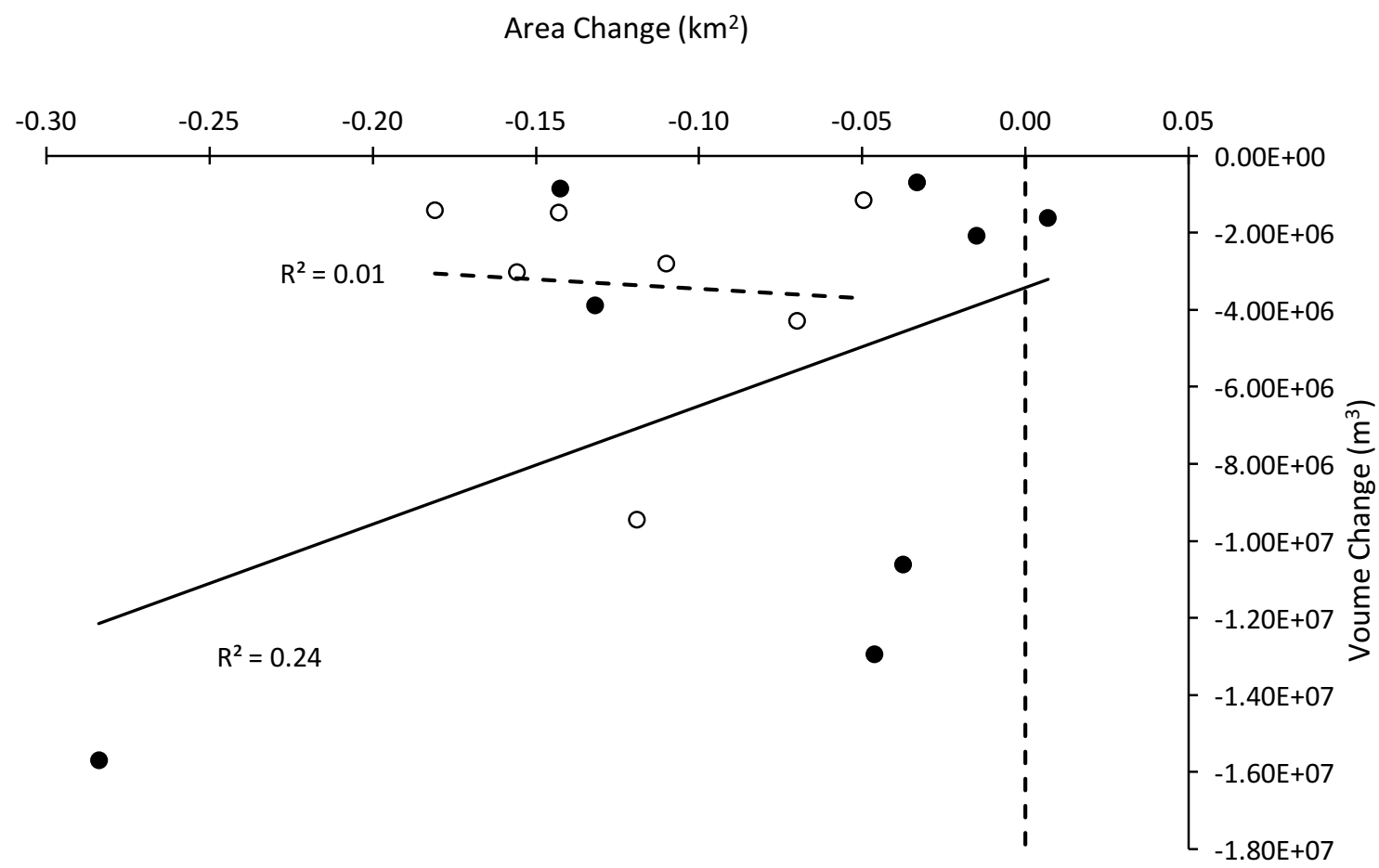

Figure 35. Volume change (1957-2010) as a function of area change. The open circles and dashed line are South Sister glaciers and the closed circles and solid line are North \& Middle Sisters glaciers.

To examine the variation of glacier volume loss or gain with elevation, the specific volume change is averaged across $100 \mathrm{~m}$ elevation bands and plotted against elevation (Figure 36). The North \& Middle Sisters glaciers on the Three Sisters have lost significant volume across their entire elevations. The elevations with the greatest volume change occurred in the $2400-2700 \mathrm{~m}$ range, and commonly peaking at 2500 and $2700 \mathrm{~m}$. The South Sister's glaciers exhibit volume loss - less volume loss to volume gain - more volume loss pattern as they move higher in elevation. This pattern is observed 
across the accumulation and ablation zones. The elevations with the greatest volume change occurred in two zones $2300-2400 \mathrm{~m}$ and $2700-2900 \mathrm{~m}$ ranges. The elevation band with the greatest fraction of volume loss was the $2700 \mathrm{~m}$ and $2800 \mathrm{~m}$ band. Most glaciers, across all of the Three Sisters, show increased volume loss around $2500 \mathrm{~m}$ and $2700 \mathrm{~m}$. The elevation band with the greatest fraction of volume loss was the $2600 \mathrm{~m}$ and 2700 $\mathrm{m}$ band, which had $31 \%$ of the total volume loss across all glaciers.

The four largest glaciers (Collier, Hayden, Diller, and Prouty) all have lost significant volume in their midsections or higher in elevation. This is likely due to the fact that these glaciers have an already thin terminus due to significant lost since the LIA and as a result there is more ice to be lost in their mid-sections.

Several glaciers exhibited areas that thickened during the $1957-2010$ period. The Diller, Hayden and Prouty had terminus thickening and advance along with the Lost Creek, and Skinner glaciers having had mid-sections that thickened. This thickening was only observed in the elevation plots for glaciers on the South Sisters (Lost Creek, Prouty, and Skinner). This thickening occurred between $2500 \mathrm{~m}$ and $2600 \mathrm{~m}$ and, as stated previously was observed with debris covered ice. 

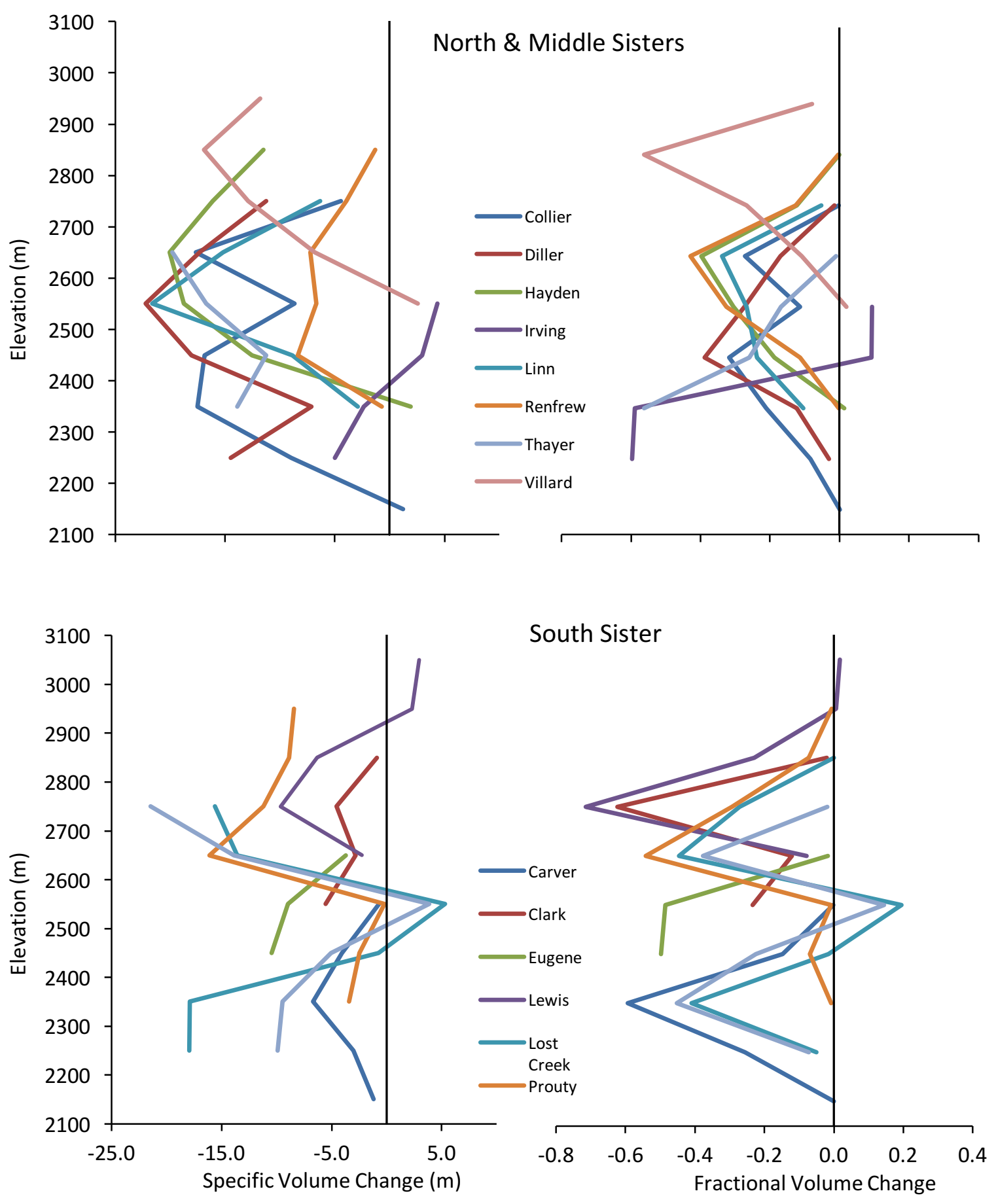

Figure 36. Specific volume change (left) and fractional volume change (Right) from 1957-2010 as a function of elevation for the North \& Middle Sister glaciers (Top) and South Sister glaciers (bottom). Data is plotted at $100 \mathrm{~m}$ intervals centered on mid-interval. 


\section{Discussion and Conclusions}

The volume change of the 15 named glaciers showed all glaciers losing mass from 1900 to 2010. It's estimated that the volume lost a total of 61\% from 1900 to 2010. Overall, glaciers lost $71.98 \times 10^{6} \pm 2.87 \times 10^{6} \mathrm{~m}^{3}$ from 1957-2010. Most glaciers lost more volume from 1957-1990 then from 1990-2010 as expected from the area change, with a few exceptions, most notable Diller Glacier. These results are comparable to the volume change study that was completed by Sisson et al. (2010) for Mount Rainier. He found that the glacier and perennial snowfields had an average specific volume change of $-7.06 \mathrm{~m}$ which is slightly less than the average of $-8.9 \mathrm{~m}$ on the Three Sisters. Over the 37/38 (1970-2007/2008) year period the glaciers on Mount Rainier lost $\sim 14 \%$ of ice and perennial snow volume, while on the Three Sisters glaciers lost $~ 53 \%$ of volume over a 53 year time period. Despite a 15 year difference in estimating volume, it is likely that the glaciers on the Three Sisters have lost a greater percentage of their ice than on Mount Rainier. The volume change decreases also compare to the overall volume decrease that has been observed in the alpine regions around the globe (Bauder et al., 2007; DeBeer and Sharp, 2007; Lambrecht and Kuhn, 2007). Bauder et al. (2007) found that selected glaciers in the Swiss Alp's lost a total volume $8.7 \mathrm{~km}^{3}$ from 1920-2007. DeBeer and Sharp (2007) found that the glaciers in the Southern Canadian Cordillera lost a volume of $13 \pm 3 \mathrm{~km}^{3}$ from 1951/52-2001. Lambrecht and Kuhn (2007) found that glaciers in the Austrian Alp's lost a total volume about $5 \mathrm{~km}^{3}$ from 1969-1998.

The uncertainty of volume change was binned by slope and, as expected, there 
were lower uncertainties in lower slopes. Each bin's uncertainty was applied to each cell depending on the slope of that cell, which resulted in a better understanding of uncertainty for the volume differencing.

The analysis of topographic controls on the volume change of the 15 named glaciers showed no significant correlations. The best outcomes were volume change relationship to mean elevation on North \& Middle Sister glaciers and volume change to slope for South Sister glaciers, with the other variables (aspect and elevation difference) showing no significance or correlation. Sisson et al. (2011) also found that there was a poor correlation with ice volume losses and aspect. Possibly a combination of variables have a major effect on volume change rather than specific variables. North \& Middle Sister glaciers with greater mean elevation showed less area change and South Sister glaciers with steeper slopes show greater volume loss.

Overall, The North \& Middle Sisters glaciers on the Three Sisters have lost significant volume across their entire elevations, and the South Sisters glaciers exhibit a more volume loss - less volume loss to volume gain - more volume loss pattern as they move higher in elevation. This observation is different than what was observed on Mount Rainier. The glaciers there exhibited a more traditional pattern of more loss in the ablation zone and thickening in the accumulation zone. The elevations with the greatest volume change occurred in the $2400-2700 \mathrm{~m}$ range, and commonly peaking at 2500 and $2700 \mathrm{~m}$. The elevation band with the greatest fraction of volume loss was the $2600 \mathrm{~m}$ and $2700 \mathrm{~m}$ band, which had 31\% of the total volume loss across all glaciers.

Several glaciers exhibited areas that thickened from 1957 through 2010. The 
Diller, Hayden, Lost Creek, Prouty, and Skinner glaciers all had sections or termini that thickened. This thickening occurred between $2450 \mathrm{~m}$ and $2600 \mathrm{~m}$ and was observed in areas that are debris-covered. Several glaciers (Prouty, Lost Creek, and Irving) show thickening around $2600 \mathrm{~m}$. It is likely that with an already thinned terminus zones, there is more glacier ice to be lost is the midsections. I suspect that debris cover was ample enough to insulate the ice. Glaciers with debris cover on their surface faced between the NW to E directions compared to glaciers with no debris on them mainly facing SE to W. This might be due to larger glaciers (Collier, Diller, Hayden, and Prouty) in these directions, erosion of the mountains. This eroded debris is being collected on the larger surface areas and lower slopes below steep headwalls with surface slopes $>40^{\circ}$. The erosion of these headwalls is most likely contributing debris to the glaciers because all of these areas are located below these steep eroding headwalls.

The relationship of volume change and debris cover was not as clear as its relationship to area change. One notable observation was that even with zones of thickening on some glaciers all of the glaciers lost volume. This was also observed on Mount Rainier (Sisson et al., 2011). The Emmons and Winthrop glaciers both had terminal thickening and advanced but still overall lost volume over the study period. In all cases these zones are debris covered. Like on both volcanoes, glaciers have seemed to follow overall decreases in volume with local zones and terminal advances that correspond to debris covered ice.

In conclusion, glacier volumes lost $\sim 53 \%$ from $1957-2010$ with higher rates of loss from 1957-1990 compared to 1990-2010, with a few exceptions, and two glaciers 
gained volume from 1990-2010. Zones of some glaciers with debris covered ice thickened over the study periods. No correlation was observed between single topographic variables. These results are comparable to changes observed on Mount Rainier (Sisson et al., 2011) and other alpine regions around the globe (Bauder et al., 2007; DeBeer and Sharp, 2007; Lambrecht and Kuhn, 2007). 


\section{Chapter Five - Historic Photos}

\section{Introduction}

The purpose of this chapter is to compile and examine the historic photographic record of the glaciers on the Three Sisters and report on the efforts to 'match' a number of the photos in order to continue the qualitative documentation of the glaciers.

\section{Historic Photos}

The historic photograph record of the glaciers on the Three Sisters is extensive (Table 22). As mentioned in previous chapters J.S. Diller first observed glaciers on the Three Sisters in the summer of 1883 on an expedition to the summits of Mt. Thielsen, Diamond Peak, and the Three Sisters (Russell, 1885). Russell noted that Diller observed a number of considerable glaciers on multiple Cascade peaks that included the Three Sisters.

Table 22. Photo list of the glaciers on the Three Sisters presented in this chapter.

\begin{tabular}{ccccc}
\hline \hline Glacier(s) & Volcano & Date & Photographer & Source/Publication \\
\hline Collier & North & August 1910 & Clarence Winter & Jim O'Connor, USGS \\
Collier & North & July 14, 1914 & EF Martin & Jim O'Connor, USGS \\
Collier & North & September 8, 1920 & FW Cleator & Jim O'Connor, USGS \\
Collier & North & September 28, 1938 & Ruth Hopson Keen & Jim O'Connor, USGS \\
Collier & North & August 11, 1944 & Ruth Hopson Keen & Jim O'Connor, USGS \\
Collier & North & September 23, 1951 & Ruth Hopson Keen & Jim O'Connor, USGS \\
Collier & North & August 14, 1973 & Ruth Hopson Keen & Jim O'Connor, USGS \\
Diller & Middle & August 16, 1903 & IC Russell & Russell, 1905 \\
Diller & Middle & September 24, 1937 & AJ Gilardi & The Mazamas \\
Diller-Hayden & Middle & September 24, 1937 & AJ Gilardi & The Mazamas \\
Diller-Hayden-Irving & Middle & August 14, 1910 & Ira Williams & Jim O'Connor, USGS \\
Hayden & Middle & August 16, 1903 & IC Russell & Russell, 1905 \\
Hayden & Middle & August 16, 1903 & IC Russell & Russell, 1905 \\
Carver-Eugene- & & & & The Mazamas \\
Irving-Lost Creek- & South & August 12, 1910 & Clarence Winter & \\
Prouty-Skinner & & & & \\
\hline
\end{tabular}


The first scientific report of the glaciers came from I.C. Russell (1905), he

included his photographs of the glaciers and of areas he observed the shrinking glaciers.

He observed that the current glacier surfaces were lower than the adjacent moraine

crest (Figure 37.)

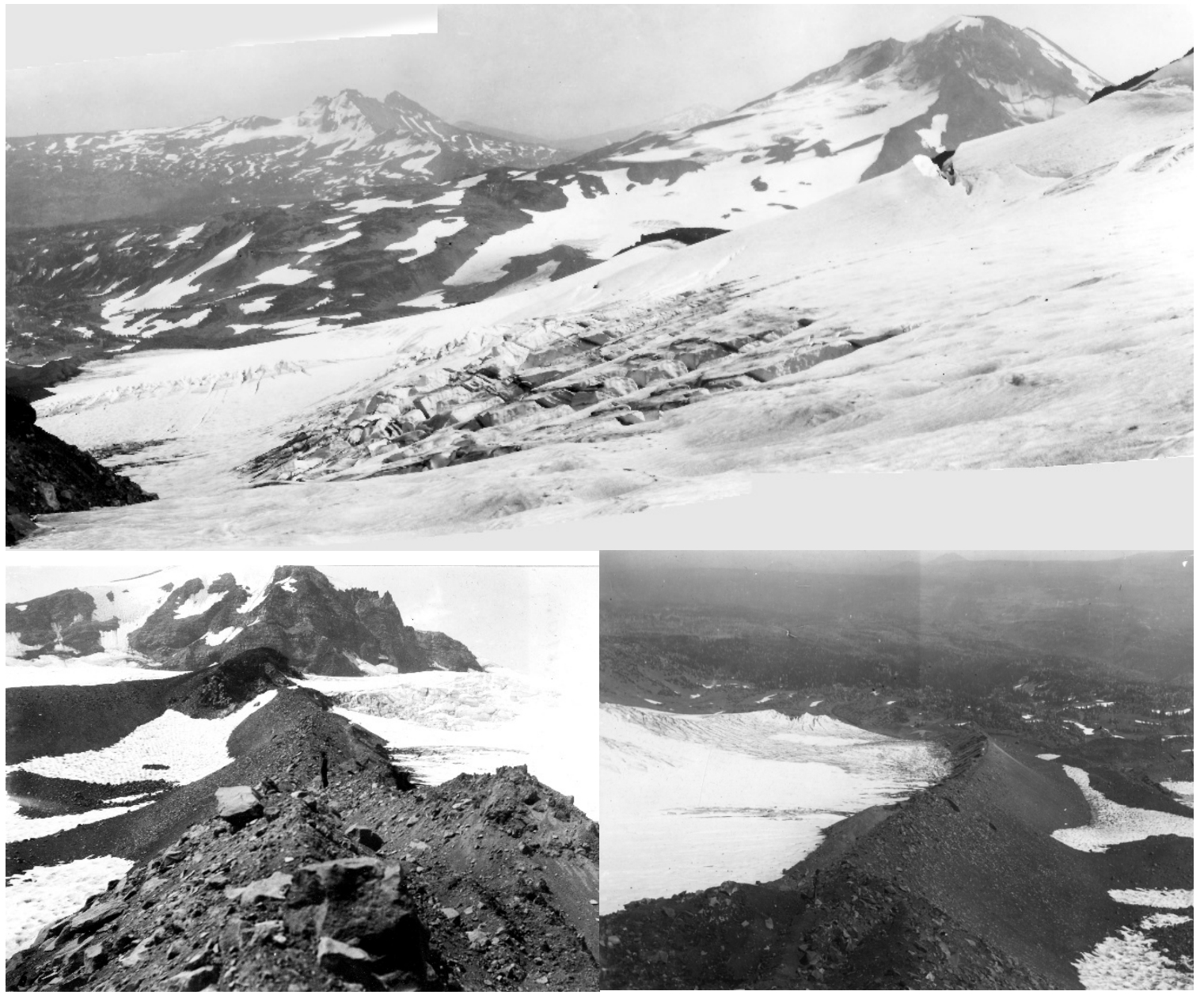

Figure 37. Clockwise from top, photo taken August 16, 1903 looking southeast towards Diller Glacier (foreground and Broken Top (background). Photo taken August 16, 1903 looking west towards Hayden Glacier (right) and Middle Sister (Background). Photo taken August 16, 1903 looking east towards Hayden Glacier. All photos taken by I.C. Russell and sourced by Dr. Jim O'Connor, USGS.

The next report on the glaciers, as noted in previous chapters, came from Edwin Hodges (1925), Mount Multnomah: Ancient Ancestor of the Three Sisters. In this report 
he reported on the geology and glaciers of the Three Sisters and his hypothesis that the volcanoes were all once part of one larger volcano he called Mount Multnomah. This hypothesis was later debunked, however in the report he noted the current glacier sizes and had a few photographs of the glaciers. These photographs mainly consisted of upclose photos of ice with no sense of reference or photos of the mountains from a far distance.

Along with the early reports and photographs many other photographs of the Three Sisters glaciers have been published by the Mazamas, an alpine hiking club in Portland, Oregon (Williams, 1916; Phillips, 1938; Hopson, 1960; Hopson, 1965). The Mazamas have both lead alpine hikes where ground based oblique photographs have been taken in the region of the Three Sisters and funded aerial photo surveys to document glaciers across the Pacific Northwest (Research Committee of the Mazamas, 1938) (Figure 38). 

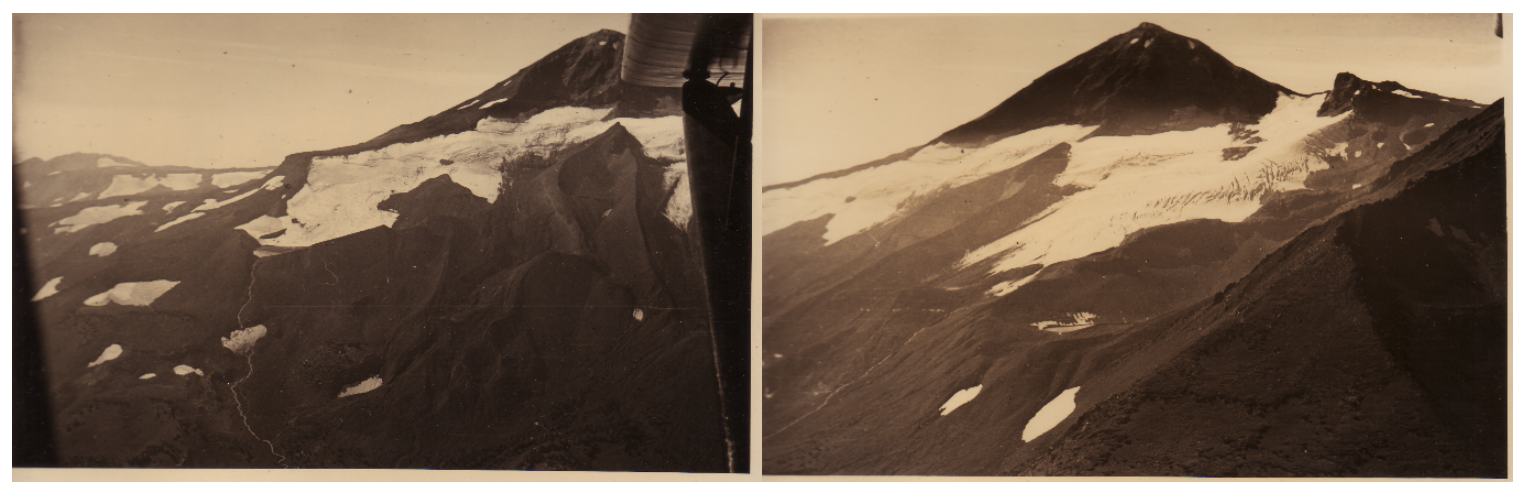

Figure 38. Aerial photographs (Photograph taken by A.J. Gilardi) of the Diller (left) and Hayden (right) glaciers taken September 24, 1937 funded by the Research Committee of the Mazamas (sourced by the Mazamas).

The Mazamas recognized that the glaciers in the Pacific Northwest had been retreating (Williams, 1916; Phillips, 1938) and in response they have funded research investigating the changing the alpine zones. Along with these efforts many other photographs have been taken across the Three Sisters in the early part of the $20^{\text {th }}$ century (Figure 39). 


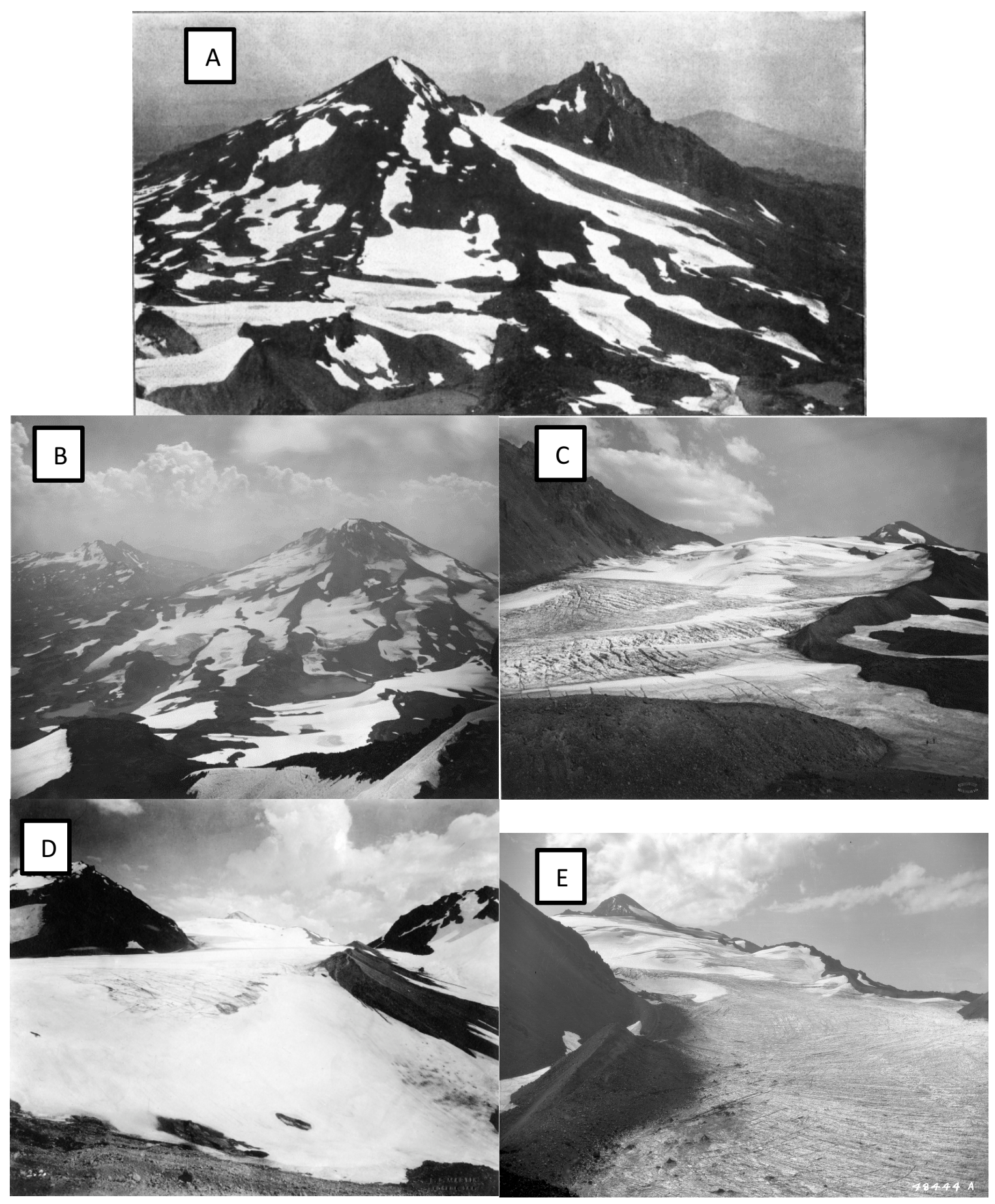

Figure 39. Historic photos of the Three Sisters and its glaciers. A) Photo taken August 14, 1910 from the south summit of South Sister looking north by Ira Williams. Photo source: Jim O'Connor, USGS. B) Photo taken August 12, 1910 from the summit of Middle Sister looking south towards South Sister and Broken Top by Clarence Winter. Photo source: Jim O'Connor, USGS courtesy of the Mazamas. C) Photo taken August 1910 from the south face of Little Brother by Clarence Winter. Photo source: Jim O'Connor, USGS. D) Photo taken July 14, 1914 from the Collier Cone looking south towards Middle Sister by E.F. Martin, USGS. Photo source: Jim O'Connor, USGS. E) Photo taken September 8, 1920 from Collier Cone looking south towards Middle Sister by Fred W. Cleator, USFS. Photo source: Jim O'Connor, USGS. 


\section{Matching}

Photographs taken with the intent of 'matching' are taken in order to document the glacier change in a qualitative sense. In the Three Sister region matching was started in the late 1930's by Dr. Ruth Hopson Keen. From 1934 to 1973 Dr. Keen took 19 matching photos of the Collier Glacier taken from Collier Cone looking south (Figure 40). Her reports published in the Mazamas Annuals (Hopson, 1960; Hopson, 1961; Hopson, 1962; Hopson, 1965) detail her observations on the changing glacier and alpine zones. Her photographs have offered an amazing window into how dramatically Collier glacier has been receding up valley from is terminus at Collier Cone in the early part of the century. 


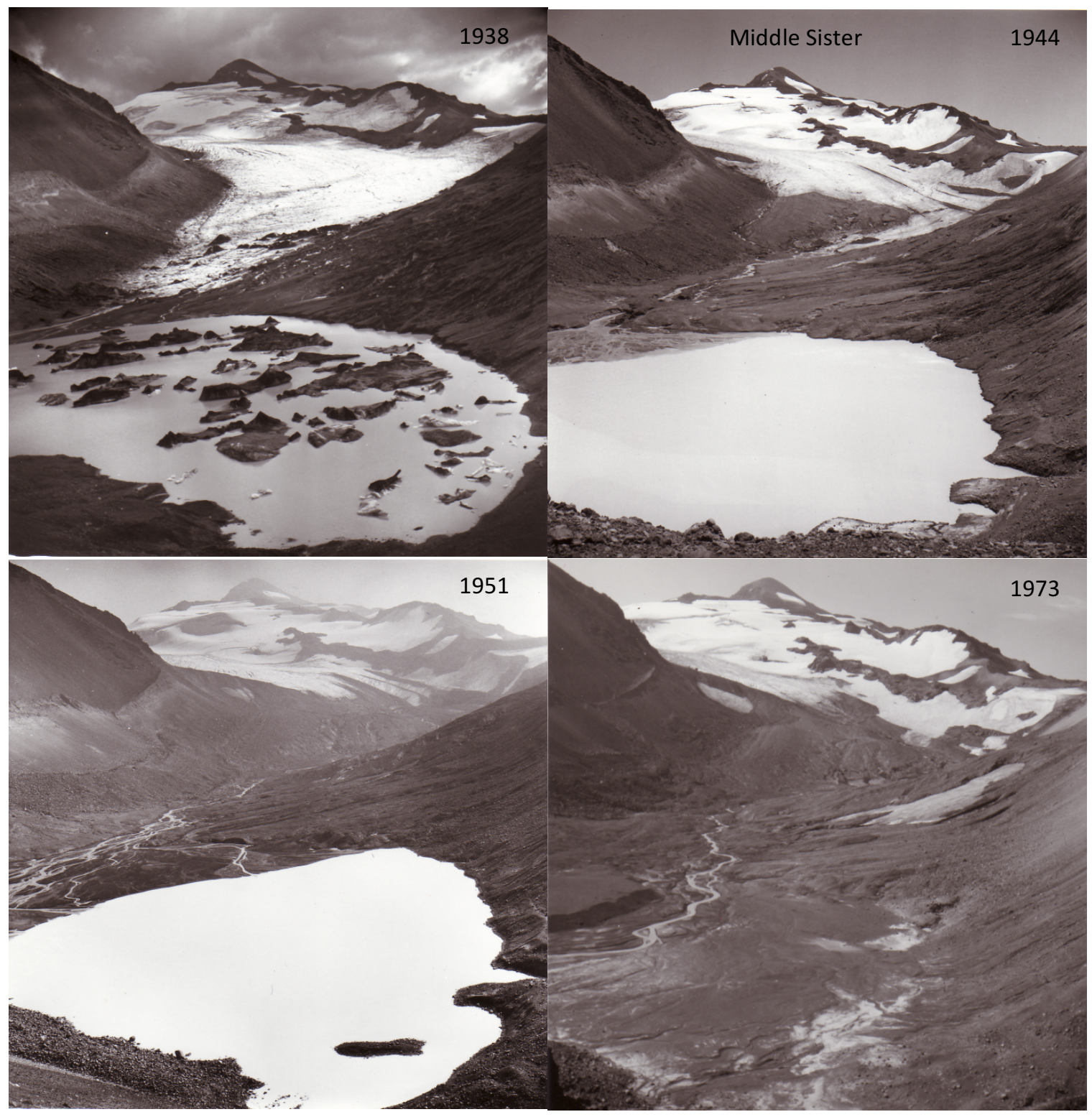

Figure 40. Ruth Hopson Keen photos of Collier Glacier taken from Collier Cone looking South towards Middle Sister. 1938) Taken September 28, 1938. 1944) Taken August 11, 1944. 1951) Taken September 23, 1951. 1973) Taken August 14, 1973. All Photos were published by the Mazamas hiking club and were sourced by Dr. Jim O'Connor at the USGS.

Photo matching was continued in the 1990's by USGS scientists Dave Wieprecht, Jasper Hardison, and Jim O'Connor. They have matched many historic photographs in the region in order to continue the documentation of the shrinking glaciers $\left(\mathrm{O}^{\prime}\right.$ Connor, 2013) (Figure 41). 

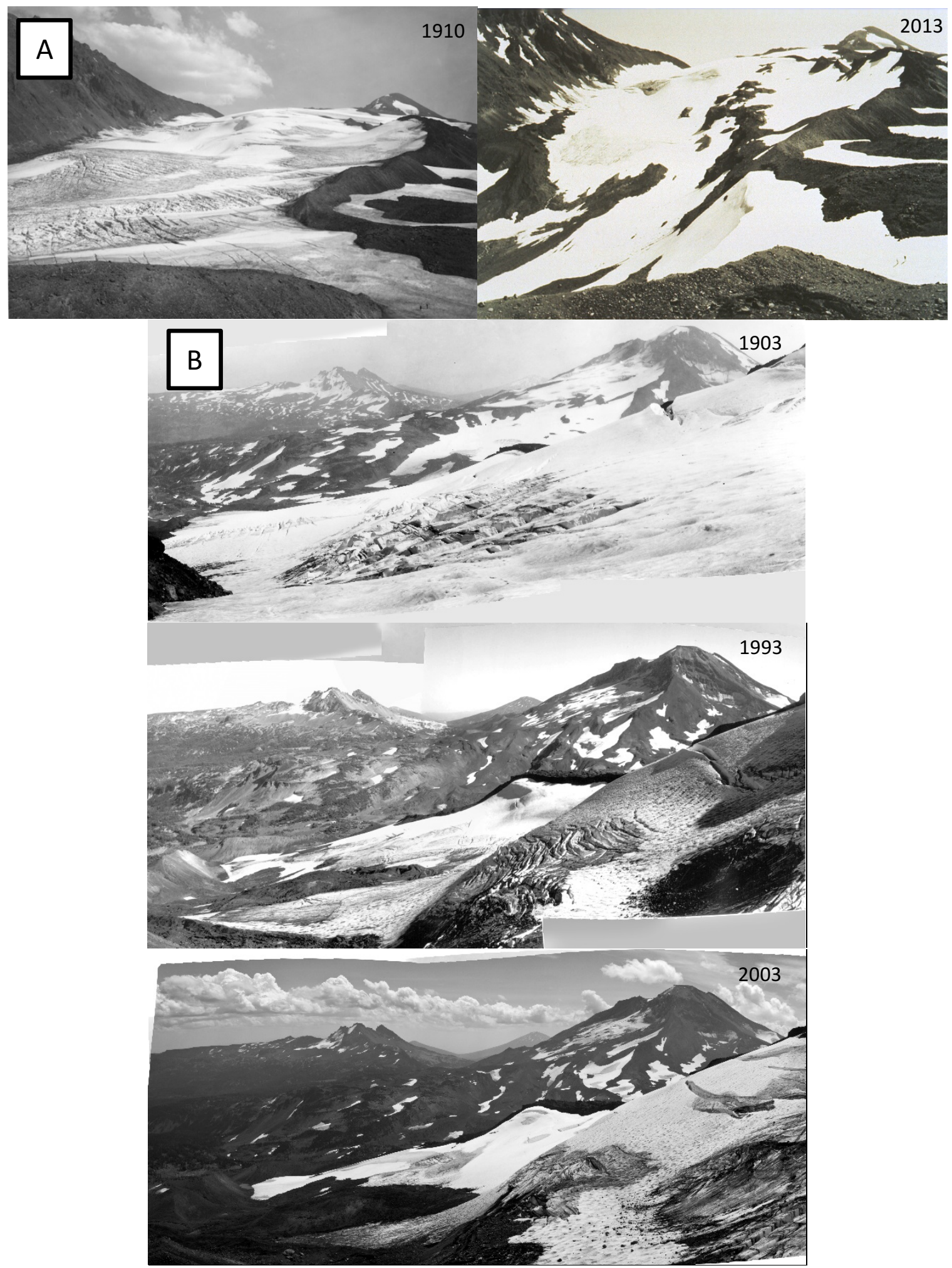

Figure 41. A) Photo of Collier Glacier Taken by Clarence Winters, August 1910, matched by Dave Wieprecht from Little Brother looking South towards Middle Sister. B) Photo taken by IC Russell August 16, 1903 with photo matches by David Weiprecht on August 16, 2003 and Jim O'Connor on August 17' 2013. All Photos were sourced by Dr. Jim O'Connor at the USGS. 

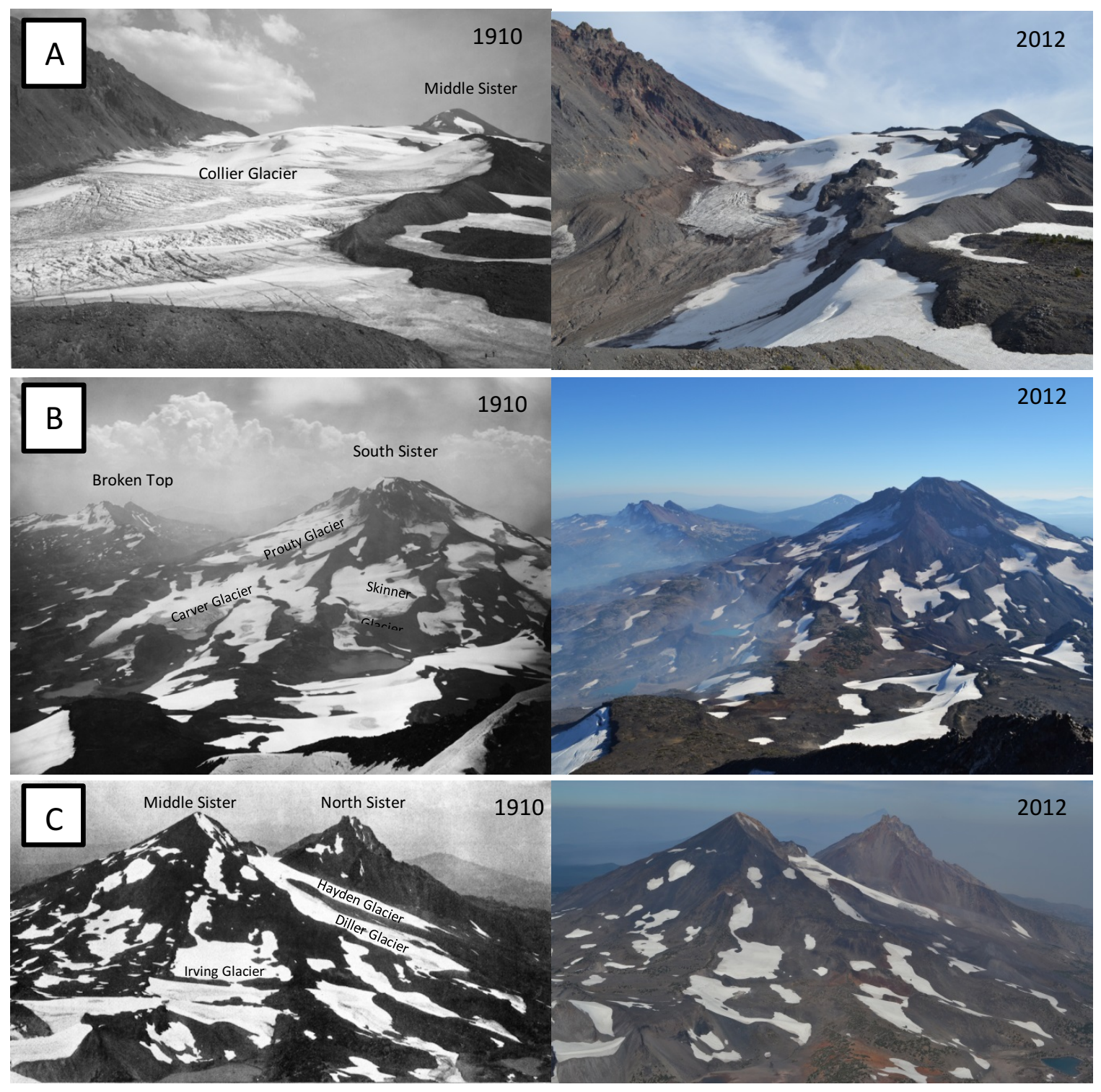

Figure 42. Photo matches of historic photos taken of the Three Sisters and its glaciers. A) 1910 photo taken August 1910 from the south face of Little Brother by Clarence Winter. Photo source: Jim O'Connor, USGS. 2012 photo from roughly same location on September 28, 2012 by Justin Ohlschlager. B) 1910 photo taken August 12, 1910 from the Summit of Middle Sister looking South towards South Sister and Broken Top by Clarence Winter. Photo source: Jim O'Connor, USGS. 2012 photo from roughly same location on October 7, 2012 by Justin Ohlschlager (notice smoke from the Pole Creek Fire). C) 1910 photo taken August 14, 1910 from the Summit of South Sister looking north towards Middle and North Sisters by Ira Williams. Photo source: Jim O'Connor, USGS. 2012 photo from roughly same location on September 27, 2012 by Justin Ohlschlager. 
Three photos were matched, the 1910 Clarence Winter photo of Collier glacier, the 1910 Clarence Winter photo of glacier on the North face of South Sister taken from the summit of Middle Sister, and the 1910 Ira Williams photo of the glaciers on the south and east faces of Middle Sister taken from the summit of South Sister.

\section{Discussion}

Historic photographs of the Three Sisters glacier offer insight as to how the glaciers have been changing qualitatively over time. They offer an opportunity to fully understand how the glaciers have been changing sometimes when no other data is present.

J.S. Diller first observed glaciers on the Three Sisters in the summer of 1883 with the first scientific publication that reported and documented the glaciers coming from I.C. Russell (1905). In his report he noted, described, and took many photos the glaciers in the region. He noticed their current surface being lower than the adjacent moraine crests. The next major report on the glaciers was from Edwin Hodges (1925). In the report he noted the current glacier sizes and had a few photographs of the glaciers. Many photographs of the Three Sisters glaciers have been published by the Mazamas taken on alpine hikes and aerial photo surveys to record the glaciers across the Pacific Northwest. They recognized that the glaciers in the Pacific Northwest had been retreating from year to year.

Photographs for 'matching' purposes were started in the late 1930's by Dr. Ruth Hopson Keen. From 1934 to 1973 Dr. Keen took 19 matching photos and her reports 
published in the Mazamas annuals detail her observations on the changing glacier and alpine zones. Photo matching was continued in the 1990's by USGS scientists Dave Wieprecht, Jasper Hardison, and Jim O'Connor. They have matched many historic photographs in the region in order to continue the documentation of the shrinking glaciers.

Continued photographic documentation of the glaciers on the Three Sisters is useful for both quantitative and qualitative purposes. They offer a low cost and effective way to record glacier extents and with the advancement of ground based photogrammetric software these photographs could offer even more insight into their dynamic change. 


\section{Chapter Six - Discussion and Conclusions}

Multiple inventories of the glaciers and perennial snowfields were compiled

from orthorectified vertical aerial imagery from 1949, 1957, 1990, and satellite imagery from 2003. The inventories in 1949 and 1957 showed 402 snow and ice features; 1990 showed 337 features. In 199065 features were missing due to insignificant coverage in imagery. In 2003121 features were found as a result of focusing on features that were found as perennial in the previous inventories. The number of perennial features was 122 for 1949 through 1990 and dropped to 121 in 2003 . The total area of the glaciers and perennial snowfields shrank from $9.03 \pm 1.65 \mathrm{~km}^{2}$ in 1949 to $7.10 \pm 1.16 \mathrm{~km}^{2}$ in 2003. Comparing the number and area of glaciers and perennial snowfields in 2003 $\left(121,7.1 \pm 1.16 \mathrm{~km}^{2}\right)$ to previous studies reveals a smaller population and area compared to the Sierra Nevada $\left(1719,39.15 \pm 7.52 \mathrm{~km}^{2}\right)$ (Basagic and Fountain, 2011) and North Cascades $\left(1935,236.20 \pm 12.60 \mathrm{~km}^{2}\right.$ ) (Dick, 2013). This is to be expected because those studies covered a much larger land area. The number and area of glaciers on the Three Sisters $(19,7.76 \pm 1.50$ in 1957) as compared to other Cascade volcanoes, Mount Hood $\left(12,7.79 \pm 0.33 \mathrm{~km}^{2}\right.$ in 1946) (Jackson, 2007), Mount Rainier $\left(26,88.11 \pm 0.99 \mathrm{~km}^{2}\right.$ in 1971) (Nylen, 2001), Mount Adams $\left(12,21.73 \pm 0.99 \mathrm{~km}^{2}\right.$ in 1969) (Sitts et al., 2010), and Mount Baker (6, $21.52 \pm 0.711 \mathrm{~km}^{2}$ in 1956) (Dick, 2013), is mostly greater in number and smaller in area with a couple of exceptions.

It was found that the $24 \mathrm{~K}$ glacier and perennial snowfield inventory did not represent the outlines of 1957, but had been updated using 1980 imagery that shows large amounts of seasonal snow and as a result, the $24 \mathrm{~K}$ inventory was not used. This 
result differed from other regional inventories that found the $24 \mathrm{~K}$ inventory to be useful (Granshaw and Fountain, 2006; Basagic and Fountain, 2011; Dick, 2013).

The average elevation (median) of the glacier and perennial snowfield increased from 1957 to 1990, from $2428 \mathrm{~m}(2365 \mathrm{~m})$ to $2432 \mathrm{~m}$ (2373 m) with most ice-covered area being found between 2300 and $2800 \mathrm{~m}$. The mean feature elevation is lower than those in the Sierra Nevada (3419 m) (Basagic and Fountain, 2011) and higher than those in the North Cascades (1948 m) (Dick, 2013). The elevation band with the greatest icecovered area also rose from over the same period, from $2400-2500 \mathrm{~m}(26.2 \%)$ in 1957 to 2500-2600 m (33.7\%) in 1990. Glaciers were found facing all directions in both 1957 and 1990, but a greater percentage was found facing the NW-E directions in $1990(85.4 \%)$ as compared to 1957 (80.7\%). This suggests the bulk of glacier cover on the volcanoes is becoming concentrated higher up as lower elevation snow and ice is being lost more towards the northerly directions. Mean slope of the glaciers showed no significant change $20.9^{\circ}$ in 1957 and $21.4^{\circ}$ in 1990 , with roughly $90 \%$ ranging from $10-30^{\circ}$. The average slopes for the glaciers and perennial snowfields are lower than compared to both the Sierra Nevada $\left(28^{\circ}\right)$ and North Cascades $\left(29.7^{\circ}\right)$. All of these results are similar to results found across the American West.

Distinguishing of glaciers from snowfields used a threshold on area $\left(0.1 \mathrm{~km}^{2}\right)$ and on shear stress. The area threshold of $0.1 \mathrm{~km}^{2}$ (which was determined to be a better estimate than a threshold of $0.05 \mathrm{~km}^{2}$ ) and shear stress test yielded 19 glaciers in 1957 with the same number of glaciers, with only two differences. In 1990, 15 glaciers were over for the area threshold and the shear stress test yielded only 9 glaciers. Based on 
these results, an area threshold of $>0.1 \mathrm{~km}^{2}$ criteria seems to be a reasonable for determining a glacier on the Three Sisters when topographic information is absent. These results seem in line with other inventories across the American West. Basagic (2008) found that perennial snow and ice features $>0.15 \mathrm{~km}^{2}$ in the Sierra Nevada of Central California all met the glacier definition. Dick (2013) found that an area threshold of $0.1 \mathrm{~km}^{2}$ in the North Cascades of Northern Washington produced similar results to the glacier definition. She also found that when reducing the shear stress threshold down to $0.925 \times 10^{5} \mathrm{~Pa}$ it matched well with previous inventories. She concluded that a shear stress threshold was a better estimate of identifying glaciers.

The glaciers and perennial snowfields on the Three Sisters have lost area over the period of $\sim 1900-2003$. Decadal changes were synchronous, with rapid retreat, advance/stabilization, and continued slower retreat. Glaciers and perennial snowfields generally advanced in the period 1949-1990. For the period 1949-2003 the glaciers and perennial snowfields that changed significantly (relative uncertainty $<1$ ) lost area -1.914 $\pm 0.097 \mathrm{~km}^{2}$ (21\%). Longer time periods exhibited more significant changes than shorter time periods. In general, smaller glaciers lost larger fractions of their area and showed more variability. Overall, time periods showed statistically significant change over the study period. The variability in the smaller glaciers with larger uncertainty masked the change that is taking place.

The 15 named glaciers lost 54\% of their area from 1900-2003, with an average loss for named glaciers of $0.404 \mathrm{~km}^{2}$, which is similar to area changes across the PNW. Thayer Glacier changed the least (-53.1\%) and the largest change was at Collier (-63.1\%). 
The area change for the named glaciers was always significant even with glaciers with smaller areas. Smaller glaciers are still observed with significant change as compared to the smaller features of perennial snow.

The change of the 15 named glaciers is consistent with other studies in the American West and Western Canada. Glaciers in the Sierra Nevada have shown a 55\% decrease in area between 1903 and 2004 (Basagic and Fountain, 2011) and glaciers in Rocky Mountain National Park have declined by 40\% from 1909-2004 (Hoffman et al., 2007). To the North, glaciers in the North Cascades including Mt. Baker have decreased by $56 \%$ from 1900-2009 (Dick, 2013), glaciers on Rainier have declined by $22 \%$ from 1913-1994 (Nylen, 2001), glaciers on Adams have declined by 49\% from 1904-2006 (Sitts el al., 2010) and on Hood glaciers have declined by 40\% from 1909-2004 (Jackson and Fountain, 2007).

Topography has no demonstrated effect on the magnitude of glacier change. Perhaps a combination of variables has major effects on area change, as shown by Basagic and Fountain (2011) and Dick (2013). However, glaciers with greater elevation difference showed less area change. This suggests that there is some relationship between glaciers with higher elevation ranges (which is related to maximum elevations) and less area change.

Rock debris cover on glacier surfaces increased by 64\% from 1949 to 2003 with the greatest increase occurring between 1957 and 1990. This corresponds with a positive but not significant correlation between the rate of area change and debris cover. Debris cover could be insulating the glaciers enough to slow down melting rates. 
This may contribute to observed area changes over the last century. Prior to 1957 glaciers deceased rapidly and had little to no rock debris cover and since then, as rock debris cover has increased, their rate of change has decreased.

Collier Glacier is a relatively good index glacier for the Three Sisters because the magnitude of area changes is roughly similar to the other glaciers in time periods with data.

The volume change of the 15 named glaciers showed all glaciers losing mass from 1900 to 2010 . It's estimated that the volume lost a total of $61 \%$ from 1900 to 2010. Overall, glaciers lost $71.98 \times 10^{6} \pm 2.87 \times 10^{6} \mathrm{~m}^{3}$ from $1957-2010$. Most glaciers lost more volume from 1957-1990 than from 1990-2010 as expected from the area change, with a few exceptions. These results are comparable to the volume change study that was completed by Sisson et al. (2010) for Mount Rainier. Over the $37 / 38$ (1970-2007/2008) year period the glaciers on Mount Rainier lost 14\% of ice and perennial snow volume, while on the Three Sisters glaciers lost $\sim 53 \%$ of volume over a 53 time period. Despite a 15 year difference in estimating volume, it is likely that the glaciers on the Three Sisters have lost a greater percentage of their ice then on Mount Rainier. The volume change decreases also compare to the overall volume decrease that has been observed in the alpine regions around the globe (Bauder et al., 2007; DeBeer and Sharp, 2007; Lambrecht and Kuhn, 2007). Bauder et al. (2007) found that selected glaciers in the Swiss Alp's lost a total volume $8.7 \mathrm{~km}^{3}$ from 1920-2007. DeBeer and Sharp (2007) found that the glaciers in the Southern Canadian Cordillera lost a volume of $13 \pm 3 \mathrm{~km}^{3}$ from 1951/52-2001. Lambrecht and Kuhn (2007) found that 
glaciers in the Austrian Alp's lost a total volume about 5 km³ from 1969-1998.

The uncertainty of volume change was binned by slope and, as expected, there were lower uncertainties in lower slopes. Each bin's uncertainty was applied to each cell depending on the slope of that cell, which resulted in a better understanding of uncertainty for the volume differencing.

The analysis of topographic controls on the volume change of the 15 named glaciers showed no significant correlations. The best outcomes were volume change relationship to mean elevation on North \& Middle Sister glaciers and volume change to slope for South Sister glaciers, with the other variables (aspect and elevation difference) showing no significance or correlation. Sisson et al. (2011) also found that there was a poor correlation with ice volume losses and aspect. Possibly a combination of variables have a major effect on volume change rather than specific variables. North \& Middle Sister glaciers with greater mean elevation showed less area change and South Sister glaciers with steeper slopes show greater volume loss.

The North \& Middle Sisters glaciers on the Three Sisters have lost significant volume across their entire elevations, and the South Sister's glaciers exhibit a more volume loss - less volume loss to volume gain - more volume loss pattern as they move higher in elevation. This observation is different than what was observed on Mount Rainier. The glaciers there exhibited a more traditional pattern of more loss in the ablation zone and thickening in the accumulation zone.

Several glaciers exhibited areas that thickened from 1957 through 2010. The Diller, Hayden, Lost Creek, Prouty, and Skinner glaciers all had sections or termini that 
thickened. This thickening occurred between $2450 \mathrm{~m}$ and $2600 \mathrm{~m}$ and was observed in areas that are debris covered. Several glaciers (Prouty, Lost Creek, and Irving) show thickening around $2600 \mathrm{~m}$. It is likely that with an already thinned terminus zones, there is more glacier ice to be lost is the midsections. I suspect that debris cover was ample enough to insulate the ice. Glaciers with debris cover on its surface faced between the NW to E directions with no debris on glaciers facing SE to W. This might be due to larger glaciers (Collier, Diller, Hayden, and Prouty) in these directions, erosion of the mountains. This eroded debris is being collected on the larger surface areas and lower slopes below steep headwalls with surface slopes $>40^{\circ}$. The erosion of these headwalls is most likely contributing debris to the glaciers because all of these areas are located below these steep eroding headwalls.

The relationship of volume change and debris cover was not as clear as its relationship to area change. One notable observation was that even with zones of thickening on some glaciers all of the glaciers lost volume. This was also observed on Mount Rainier (Sisson et al., 2011). The Emmons and Winthrop glaciers both had terminal thickening and advanced but still overall lost volume over the study period. In all cases these zones are debris covered. Like on both volcanoes, glaciers have seemed to follow overall decreases in volume with local zones and terminal advances that correspond to debris covered ice.

Historic photographs of the Three Sisters glacier offer insight as to how the glaciers have been changing qualitatively over time. They offer an opportunity to fully understand how the glaciers have been changing sometimes when no other data is 
present. Continued photographic documentation of the glaciers on the Three Sisters is important for quantitative and qualitative purposes. They offer a low cost and effective way to record glacier extents and with the advancement of ground based photogrammetric software these photographs could offer even more insight into their dynamic change. 


\section{Future Work}

There is more work to be done in the investigation of the glaciers on the Three Sisters. The first step would be the search for more aerial photography in the area in order to fine tune the area change trends throughout the last century. Next, would be to get quality data in order to pin down the current extent of the glaciers in 2015.

Another step would be to continue the volume change calculations with the soon to be released lidar dataset collected for DOGAMI in September 2014. In addition to this, developing quality DEMs from historical aerial photographs would be critical for understanding how the volume has been change in more detail.

An analysis of the area and volume change compared to the climatic changes in the region is needed. Glaciers respond to these changes and understanding their relationship could offer better insight into how the glaciers have been changing as well as how they will change in the future. 


\section{References}

Andresassen, L.M., Paul, F., Kääb, A., and Hausberg, J.E., 2008, Landsat-derived glacier inventory for Jotunheimen, Norway, and deduced changes since the 1930s, The Cryosphere, v. 2, p. 131-145.

Aniya, M., 1988, Glacier inventory for the northern Patagonia icefield, Chile, and variations 1944/45 to 1958/86, Arctic, and Alpine Research, v. 20, n. 2, p. 1979187.

Bahr, D.B., Meier, M.F., and Peckham, S.D., 1997, The physical basis of glacier volumearea scaling, Journal of Geophysical Research, v. 102, n. 89, p. 20,355-20,362

Basagic, H.J, 2008, Quantifying twentieth century glacier change in the Sierra Nevada, California [M.S. Thesis]: Portland State University, 103 p.

Basagic, H.J, and Fountain, A.G., 2011, Quantifying $20^{\text {th }}$ Century Glacier Change in the Sierra Nevada, California, Arctic, Antarctica, and Alpine Research, v. 43, n. 3, p. 317-330.

Beedlow, A.C., 2010, The Use of Surface Energy Balance Models as a Means to Quantify Changes in Glacier Mass Balance: an Application to the Collier Glacier [M.S. thesis]: Oregon State University, 235p.

Bolch, T., Yao, T., Kang, S., Buchroithner, M.F., Scherer, D., Maussion, F., Huintjes, E., and Schneider, C., 2010, A glacier inventory for the western Nyainqentanglha Range and the Nam Co Basin, and glacier changes 1976-2009, The Cryosphere, v. 4, p. 419-433.

Bauder, A., Funk, M., and Huss, M., 2007, Ice-volume changes of selected glaciers in the Swiss Alps since the end of the $19^{\text {th }}$ century, Annals of Glaciology, v. 46, n. 1 , . 145-149.

Cannon, C., Leonard, J.L., and Fountain, A.G., unpublished, Glacier change in Oregon 1935-2007: An analysis of Mazamas aerial photographs.

Chao, Y., Gjil. M., Li, X., and McWilliams, J.C., 2000, Pacific Interdecadal Variability in This Century's Sea Surface Temperatures, Geophysical Research Letters, v. 27, n. 15, p. 2261-2264.

Chen, J., and Ohmura, A., 1990, Estimation of alpine glacier water resources and their change since the 1870s., International Association of Hydrological Sciences Publication, v. 193, p. 127-135. 
Crandell, D.R., and Miller, R.D., 1974, Quaternary stratigraphy and extent of glaciation in the Mount Rainier Region, Washington, U.S. Geological Survey Professional Paper 847, 59p.

Cuffey, K.M., and Paterson, W.S.B., 2010, The physics of glaciers, ButterworthHeinemann/Elsevier, Burlington, MA, 693p.

DeBeer, C.M., and Sharp, M.J., 2007, Recent changes in glacier area and volume within the southern Canadian Cordillera, Annals of Glaciology, v. 46, p. 215-221.

DeBeer, C.M., and Sharp, M.J., 2009, Topographic influences on recent changes of very small glaciers in the monashee mountains, British Columbia, Canada, Journal of Glaciology, v. 55, n. 192, p. 691-700.

DeVisser, M.H., and Fountain, A. G., 2015, A century of glacier change in the Wind river Range, WY, Geomorphology, v. 232, p. 103-116.

Dick, K.A., 2013, Glacier Change in the North Cascades, Washington: 1900-2009 [M.S. thesis]: Portland State University, 130p.

Driedger, C.L., and Kennard, P.M., 1986, Glacier Volume Estimation On Cascade Volcanoes: An Analysis And Comparison With Other Methods, Annals of Glaciology, v. 8, p. 59-64.

Dyurgerov, M. B., and Meier, M. F., 2000, Twentieth century climate change: Evidence from small glaciers, PNAS, v. 97, n. 4, p. 1406-1411.

Dyurgerov, M.B., Meier, M.F., and Bahr, D.B., 2009, A new index of glacier area change: a tool for glacier monitoring, Journal of Glaciology, v. 55, n. 192, p. 710-716.

Eos, Systems Inc. 2004, Photomodeler User Manual.

Fountain, A.G., and Tangborn, W.V., 1985, The effect of glaciers on streamflow variations, Water Resources Research, v. 21, n. 4, p. 579-586.

Fountain, A.G., Krimmel, R.M., and Trabant, D.C. 1997.,A strategy for monitoring glaciers. U.S. Geological Survey Circular 1132, 16 p.

Fountain, A.G., Hoffman, M., Jackson, K., Basagic, H., Nylen, T., and Percy, D., 2007, Digital outlines and topography of the glaciers of the American West, U.S. Geological Survey Open-File Report 2006-1340, 23 p.

Ghilani, C.D., 2000, Demystifying Area Uncertainty: More or Less, Surveying and Land Information Systems, v. 60 p. 177-182. 
Granshaw, F.D., and Fountain, A.G., 2006, Glacier change (1958-1998) in the North Cascades National Park Complex, Washington, USA, Journal of Glaciology, v. 52, n. 177 , p. 251-256.

Grove, J.M., 1988, The Little Ice Age, London, Routledge, 498 p.

Haeberli, W., 1995, Glacier fluctuations and climate change detection - Operational elements of a worldwide monitoring strategy, Bulletin Meteorological Organization, v. 44, n. 1, p. 23-31.

Hall, M.H.P., and Fagre, D.B., 2003, Modeled climate-induced glacier change in Glacier National Park, 1850-2100, BioScience, V. 53, n. 2, p. 131-140.

Hamlet, A.F., Mote, P.W., Clark, M.P., and Lettermaier, D.P., 2005, Effects of temperature and precipitation variability on snowpack trends in the western United States, Journal of Climate, v. 18, p. 4545-4561.

Hodge, E.T., 1925, Mount Multnomah - Ancient ancestor of the Three Sisters, University of Oregon, 158p.

Hodge, S.M., Trabant, D.C., Krimmel, T.A., Heinrichs, R.S., March, R.S., and Josberger, E.G., 1998, Climate variations and changes in mass of three glaciers in Western North America, Journal of Climate, v.11, n. 9, p. 2161-2179

Hoffman, M.J., Fountain, A.G., and Achuff, J.M., 2007, $20^{\text {th }}$-century variations in area of cirque glaciers and glacierets, Rocky Mountain National Park, Rocky Mountains, Colorado, USA, Annals of Glaciology, v. 46, p. 349-354.

Hopson, R.E., 1960, Collier Glacier - A Photographic Record, Mazama, v. 42, p. 15-26.

Hopson, R.E., 1961, Collier Glacier, 1961, Mazama, v. 43, n. 13, p. 37-39.

Hopson, R.E., 1962, Collier Glacier, 1962, Mazama, v. 44, n. 13, p. 44-47.

Hopson, R.E., 1963, Collier Glacier, 1963, Mazama, v. 45, n. 13, p. 48-49.

Hopson, R.E., 1965, Collier Glacier, 1965, Mazama, v. 47, n. 13, p. 54-56.

Jackson, K.M., 2007, Spatial and morphological change of the Elliot Glacier, Mount Hood, Oregon [M.S. Thesis], Portland State University, 111p.

Jackson, K.M., and Fountain A.G., 2007, Spatial and morphological change on Eliot Glacier, Mount Hood, Oregon, USA. Annals of Glaciology, v. 46, p. 222-226. 
Lambrecht, A., and Kuhn, M., 2007, Glacier changes in the Austrian Alps during the last three decades, derived from new Austrian glacier inventory, Annals of Glaciology, v. 46, n. 1, p. 177-184.

Legg, N.T., 2013, Debris flows in glaciated catchments : a case study on Mount Rainier, Washington [M.S. Thesis]: Oregon State University, 149 p.

Mass, C., 2008, The weather of the Pacific Northwest. Seattle: University of Washington Press.

Marcott, S.A., Fountain, A.G., O'Connor, J.E., Sniffen, P.J., and Dethier, D.P., 2009, A latest Pleistocene and Holocene glacial history and paleoclimate reconstruction at Three Sisters and Broken Top Volcanoes, Oregon, USA, Quaternary Research, v. 71, p. 181-189.

McCabe, G.J., and Fountain, A.G., 1995, Relations between atmospheric circulation and mass balance of South Cascade Glacier, Washington, U.S.A., Arctic and Alpine Research, v. 27, n. 3, p. 226-233.

McCabe, G.J., and Fountain, A.G., 2013, Glacier variability in the conterminous United States during the twentieth century, Climatic Change, v. 116, p. 565-577.

McDonald, G.D., 1995, Changes in mass of Collier Glacier, Oregon [M.S. thesis]: Oregon State University, $215 \mathrm{p}$.

Mote, P.W., 2003, Trends in temperature and precipitation in the Pacific Northwest during the Twentieth Century, Northwest Science: Official Publications of the Northwest Scientific Association, v. 77 n. 4, p. 271-282.

Mote, P.W., 2006, Climate-Driven Variability and Trends in Mountain Snowpack in Western North America, Journal of Climate, v. 19, p. 6209-6220.

Nylen, T.H., 2001, Spatial and Temporal Variations of Glaciers (1913-1994) on Mt. Rainier and the Relation with Climate [M.S. thesis]: Portland State University, $114 \mathrm{p}$.

O'Connor, J.E., Hardison, J.H.I., and Costa, J.E., 2001, Debris flows from failures of Neoglacial age moraine dams in the Three Sisters and Mount Jefferson Wilderness Area, Oregon, U.S. Geological Survey Professional Paper 1606, 93 p.

O'Connor, J.E., 2013, Our Vanishing Glaciers: One hundred years of glacier retreat in Three Sisters Area, Oregon Cascade Range, Oregon Historical Quarterly, v. 114, n. 4, p. 402-427. 
Oerlemans, J., 2005, Extracting a Climate Signal from 169 Glacier Records, Science 308, p. 675-677.

Phillips, K.N., 1938, Our Vanishing Glaciers: Observations by Mazama Research Committee on Glaciers of the Cascade Range in Oregon, Mazama, v. 20, p. 24-41.

Pirot, R., 2010, Initiation zone characterization of debris flows in November, 2006, Mount Hood, Oregon [M.S. Thesis]: Portland State University, 180 p.

Raub, W., Brown, C.S., and Post, A., 2006, Inventory of the glaciers in the Sierra Nevada, California, U.S. Geological Survey Open-File Report 2006-1239, 228p.

Research Committee of The Mazamas, 1938, An aerial photographic survey of the glaciers of Mount Hood, Mount Jefferson and the Three Sisters, Oregon, Mazama, p.47.

Ruffner, J.A., 1985, Climate of the States: National Oceanic and Atmospheric Administration narrative summaries, tables, and maps for each state, with overview of state climatologist programs, Gale Research Company, Detriot, Michigan.

Russell, I.C., 1885, Existing glaciers of the United States, U.S. Geological Survey Fifth Annual report (1883-1884), p. 303-355.

Russell, I.C., 1905, Preliminary report on the geology and water resources of central Oregon, U.S. Geological Survey Bulletin 252, 138p.

Sigafoos, R.S., and Hendricks, E.L., 1972, Recent activity of glaciers of Mount Rainier, Washington, U.S. Geological Survey Professional Paper 387-B, 24p.

Sitts, D.J., Fountain, A.G., and Hoffman, M., 2010, Twentieth Century Glacier Change on Mount Adams, Washington, USA, Northwest Science, v. 84, p. 378-385.

Sisson, T.W., Robinson, J.E., and Swinney, D.D., 2011, Whole-edifice ice volume change A.D. 1970 to 2007/2008 at Mount Rainier, Washington, based on LiDAR surveying, Geology, v. 39, n. 7, p. 639-642.

Spicer, R.C., 1986, Glaciers in the Olympic Mountains, Washington: Present distribution and recent variations [M.S. thesis]: University of Washington, 158p.

Taylor, G.H., 1993, Normal annual precipitation, State of Oregon: Oregon Climate Service, Corvallis, Oregon.

USGS, 2010, U.S. Geological Survey, The National Map Seamless Server, http://viewer.nationalmap.gov/viewer/ 
Williams, I.A., 1916, Glaciers of the Three Sisters [Oregon], Mazamas, v. 5, p. 14-23.

Wozniak, K.C., 1982, Geology of the northern part of the southeast Three Sisters quadrangle, Oregon [M.S. Thesis]: Oregon State University, 98 p.

Zhang, Y., Wallace, J.M., and Battisti D.S., 1997, ENSO-like Interdecadal Variability: 190093. Journal of Climate, v. 10, n. 5, p. 1004-102.

Zhang, K, Whitman, D., Leatherman, S., and Robertson, W., 2005, Quantification of beach changes caused by Hurricane Floyd along Florida's Atlantic coast using airborne laser surveys, Journal of Coastal Research, v. 21, n. 1, p. 123-134. 


\section{Appendix A - LIA Glacier Outline Inventories Maps}

The outlines of the 15 named glaciers (in red) for the LIA identified by a combination of aped moraines from O'Connor et al. (2001), 1990 aerial imagery, and the 2010 lidar dataset. Maps are in WGS 84 UTM Zone 10. A) North \& Middle Sisters and B) South Sisters.

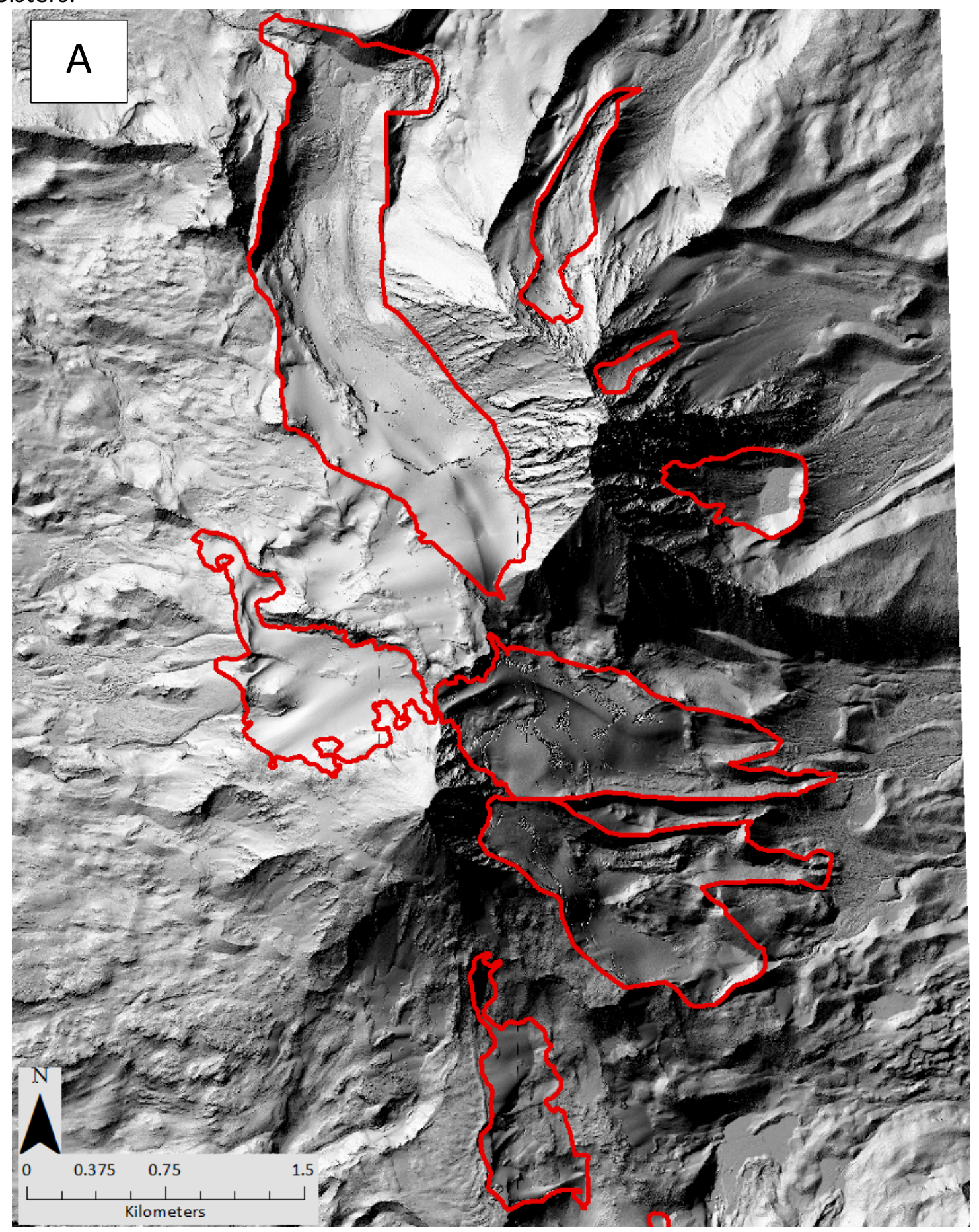




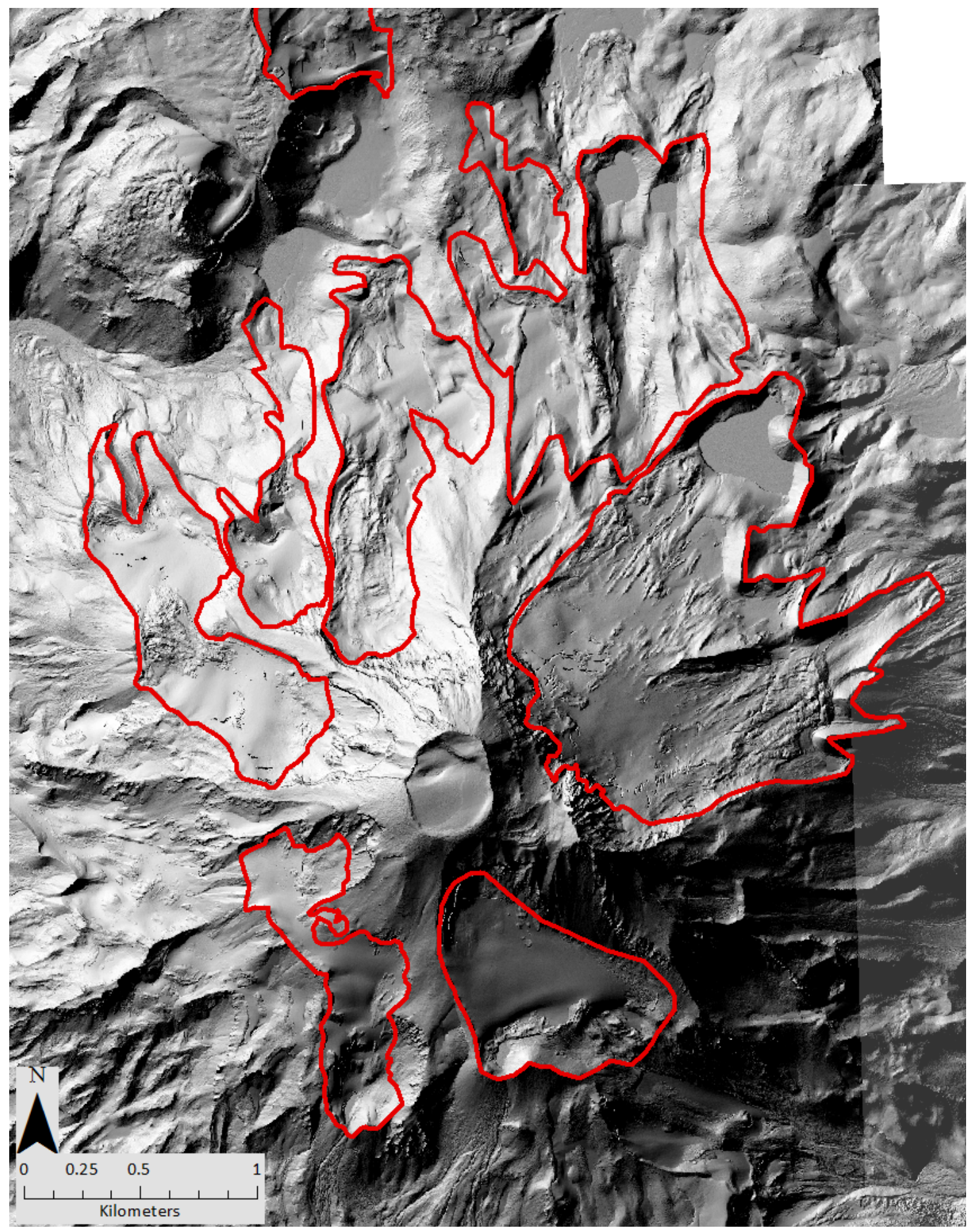




\section{Appendix B - Glacier Inventories Features}

Each feature from the inventories is listed below with the following attributes, Glacier Name, TS_ID is the unique identifier, RECNO are the values from the original $24 \mathrm{~K}$ dataset (Fountain et al., 2007), Perennial - determined as a perennial glacier or snowfield, $\mathrm{S}$ - is the mean slope $\left({ }^{\circ}\right), \mathrm{Z}$ - is the mean elevation $(\mathrm{m}), \mathrm{D}$ - is the mean aspect $\left.{ }^{\circ}\right)$. The topographic statistics were calculated for 1957 and 1990.

1949

\begin{tabular}{|c|c|c|c|c|c|c|c|c|c|c|}
\hline $\begin{array}{l}\text { Glacier } \\
\text { Name }\end{array}$ & TS_ID & RECNO & Perennial & $\begin{array}{l}\text { Area } \\
\left(\mathrm{km}^{2}\right)\end{array}$ & $\begin{array}{c}\text { Uncertainty } \\
\left(\mathrm{km}^{2}\right)\end{array}$ & $S$ & Z & Zmin & $Z \max$ & $\mathrm{D}$ \\
\hline & 1 & & $x$ & 0.00533 & 0.00358 & - & - & - & - & - \\
\hline & 2 & & & 0.00236 & 0.00204 & - & - & - & - & - \\
\hline & 3 & & & 0.00245 & 0.00219 & - & - & - & - & - \\
\hline & 4 & & $x$ & 0.01470 & 0.00710 & - & - & - & - & - \\
\hline & 5 & & $x$ & 0.02635 & 0.01313 & - & - & - & - & - \\
\hline & 6 & & $x$ & 0.03289 & 0.00899 & - & - & - & - & - \\
\hline & 7 & & $x$ & 0.00508 & 0.00362 & - & - & - & - & - \\
\hline & 8 & & $x$ & 0.05083 & 0.02157 & - & - & - & - & - \\
\hline & 9 & & $x$ & 0.00781 & 0.00461 & - & - & - & - & - \\
\hline & 10 & & $x$ & 0.01671 & 0.00866 & - & - & - & - & - \\
\hline & 11 & & $x$ & 0.00691 & 0.00459 & - & - & - & - & - \\
\hline & 12 & & $x$ & 0.00983 & 0.00515 & - & - & - & - & - \\
\hline & 13 & & & 0.00780 & 0.00485 & - & - & - & - & - \\
\hline & 14 & & & 0.00112 & 0.00194 & - & - & - & - & - \\
\hline & 15 & & & 0.01385 & 0.01377 & - & - & - & - & - \\
\hline & 16 & & & 0.00131 & 0.00149 & - & - & - & - & - \\
\hline & 17 & 4194 & $x$ & 0.01230 & 0.00839 & - & - & - & - & - \\
\hline & 18 & 4196 & $x$ & 0.01755 & 0.02006 & - & - & - & - & - \\
\hline & 19 & 4198 & $x$ & 0.02522 & 0.00817 & - & - & - & - & - \\
\hline & 20 & 4201 & $x$ & 0.01455 & 0.00881 & - & - & - & - & - \\
\hline & 21 & 4202 & $x$ & 0.00995 & 0.00395 & - & - & - & - & - \\
\hline & 22 & 4204 & & 0.00250 & 0.00362 & - & - & - & - & - \\
\hline & 23 & 4205 & $x$ & 0.01940 & 0.01104 & - & - & - & - & - \\
\hline & 24 & 4206 & $x$ & 0.03270 & 0.01386 & - & - & - & - & - \\
\hline \multirow[t]{2}{*}{ Renfrew } & 25 & 4207 & $x$ & 0.50036 & 0.01371 & - & - & - & - & - \\
\hline & 26 & 4208 & $x$ & 0.12180 & 0.04435 & - & - & - & - & - \\
\hline \multirow[t]{7}{*}{ Collier } & 27 & 4209 & $x$ & 0.96858 & 0.04592 & - & - & - & - & - \\
\hline & 28 & 4209 & $x$ & 0.18674 & 0.03038 & - & - & - & - & - \\
\hline & 29 & 4210 & $x$ & 0.03581 & 0.01018 & - & - & - & - & - \\
\hline & 30 & 4211 & $x$ & 0.04381 & 0.01634 & - & - & - & - & - \\
\hline & 31 & 4212 & $x$ & 0.00978 & 0.00399 & - & - & - & - & - \\
\hline & 32 & 4213 & & 0.00078 & 0.00333 & - & - & - & - & - \\
\hline & 33 & 4214 & $x$ & 0.02007 & 0.00760 & - & - & - & - & - \\
\hline \multirow[t]{2}{*}{ Thayer } & 34 & 4216 & $x$ & 0.11144 & 0.02273 & - & - & - & - & - \\
\hline & 35 & 4217 & & 0.00569 & 0.00395 & - & - & - & - & - \\
\hline
\end{tabular}




\begin{tabular}{|c|c|c|c|c|c|c|c|c|c|c|}
\hline $\begin{array}{l}\text { Glacier } \\
\text { Name }\end{array}$ & TS_ID & RECNO & Perennial & $\begin{array}{l}\text { Area } \\
\left(\mathrm{km}^{2}\right)\end{array}$ & $\begin{array}{c}\text { Uncertainty } \\
\left(\mathrm{km}^{2}\right)\end{array}$ & $S$ & Z & Zmin & $Z \max$ & $\mathrm{D}$ \\
\hline & 36 & 4219 & $x$ & 0.00560 & 0.00387 & - & - & - & - & - \\
\hline & 37 & 4220 & $x$ & 0.00870 & 0.00760 & - & - & - & - & - \\
\hline & 38 & 4221 & $x$ & 0.01103 & 0.00807 & - & - & - & - & - \\
\hline & 39 & 4222 & $x$ & 0.00916 & 0.00913 & - & - & - & - & - \\
\hline & 40 & 4223 & $x$ & 0.00706 & 0.00416 & - & - & - & - & - \\
\hline & 41 & 4224 & $x$ & 0.00686 & 0.00733 & - & - & - & - & - \\
\hline & 42 & 4225 & $x$ & 0.00933 & 0.00405 & - & - & - & - & - \\
\hline & 43 & 4226 & $x$ & 0.02243 & 0.01368 & - & - & - & - & - \\
\hline Villard & 44 & 4227 & $x$ & 0.04464 & 0.00389 & - & - & - & - & - \\
\hline \multirow[t]{20}{*}{ Linn } & 45 & 4228 & $x$ & 0.12622 & 0.00775 & - & - & - & - & - \\
\hline & 46 & 4229 & & 0.03517 & 0.01665 & - & - & - & - & - \\
\hline & 47 & 4233 & $x$ & 0.00845 & 0.00424 & - & - & - & - & - \\
\hline & 48 & 4234 & $x$ & 0.02520 & 0.00802 & - & - & - & - & - \\
\hline & 49 & 4237 & & 0.04503 & 0.01053 & - & - & - & - & - \\
\hline & 50 & 4242 & & 0.00357 & 0.00274 & - & - & - & - & - \\
\hline & 51 & 4243 & & 0.04017 & 0.01804 & - & - & - & - & - \\
\hline & 52 & 4244 & $x$ & 0.04220 & 0.01444 & - & - & - & - & - \\
\hline & 53 & 4245 & & 0.00441 & 0.00372 & - & - & - & - & - \\
\hline & 54 & 4246 & & 0.01283 & 0.00477 & - & - & - & - & - \\
\hline & 55 & 4247 & & 0.00771 & 0.00570 & - & - & - & - & - \\
\hline & 56 & 4248 & & 0.02148 & 0.00981 & - & - & - & - & - \\
\hline & 57 & 4250 & $x$ & 0.07856 & 0.03108 & - & - & - & - & - \\
\hline & 59 & 4252 & $x$ & 0.04103 & 0.01521 & - & - & - & - & - \\
\hline & 60 & 4254 & $x$ & 0.01799 & 0.00724 & - & - & - & - & - \\
\hline & 61 & 4255 & $x$ & 0.04327 & 0.02476 & - & - & - & - & - \\
\hline & 62 & 4256 & $x$ & 0.00763 & 0.00559 & - & - & - & - & - \\
\hline & 63 & 4257 & $x$ & 0.01416 & 0.00600 & - & - & - & - & - \\
\hline & 64 & 4258 & $x$ & 0.02315 & 0.00838 & - & - & - & - & - \\
\hline & 66 & 4260 & $x$ & 0.08983 & 0.03685 & - & - & - & - & - \\
\hline \multirow[t]{6}{*}{ Irving } & 68 & 4262 & $x$ & 0.30547 & 0.05949 & - & - & - & - & - \\
\hline & 69 & 4263 & $x$ & 0.00885 & 0.00377 & - & - & - & - & - \\
\hline & 70 & 4264 & $x$ & 0.08524 & 0.02003 & - & - & - & - & - \\
\hline & 71 & 4265 & $x$ & 0.11904 & 0.03156 & - & - & - & - & - \\
\hline & 72 & 4266 & $x$ & 0.04648 & 0.01614 & - & - & - & - & - \\
\hline & 73 & 4268 & & 0.02364 & 0.00744 & - & - & - & - & - \\
\hline \multirow[t]{2}{*}{ Skinner } & 74 & 4270 & $x$ & 0.40526 & 0.06607 & - & - & - & - & - \\
\hline & 75 & 4271 & $x$ & 0.09015 & 0.02147 & - & - & - & - & - \\
\hline \multirow[t]{6}{*}{ Prouty } & 76 & 4272 & $x$ & 1.07183 & 0.03928 & - & - & - & - & - \\
\hline & 77 & 4273 & $x$ & 0.16180 & 0.05699 & - & - & - & - & - \\
\hline & 78 & 4274 & $x$ & 0.02582 & 0.01546 & - & - & - & - & - \\
\hline & 80 & 4277 & $X$ & 0.01113 & 0.00834 & - & - & - & - & - \\
\hline & 81 & 4278 & & 0.01691 & 0.01271 & - & - & - & - & - \\
\hline & 82 & 4280 & $x$ & 0.01713 & 0.00838 & - & - & - & - & - \\
\hline \multirow[t]{5}{*}{ Clark } & 83 & 4281 & $x$ & 0.25864 & 0.02931 & - & - & - & - & - \\
\hline & 84 & 4282 & & 0.00220 & 0.00272 & - & - & - & - & - \\
\hline & 85 & 4283 & $x$ & 0.01605 & 0.01095 & - & - & - & - & - \\
\hline & 86 & 4284 & $x$ & 0.01675 & 0.00735 & - & - & - & - & - \\
\hline & 87 & 4286 & $x$ & 0.02926 & 0.01736 & - & - & - & - & - \\
\hline
\end{tabular}




\begin{tabular}{|c|c|c|c|c|c|c|c|c|c|c|}
\hline $\begin{array}{c}\text { Glacier } \\
\text { Name }\end{array}$ & TS_ID & RECNO & Perennial & $\begin{array}{l}\text { Area } \\
\left(\mathrm{km}^{2}\right)\end{array}$ & $\begin{array}{c}\text { Uncertainty } \\
\left(\mathrm{km}^{2}\right)\end{array}$ & $S$ & Z & Zmin & $Z \max$ & $\mathrm{D}$ \\
\hline & 88 & 4287 & $x$ & 0.04970 & 0.03793 & - & - & - & - & - \\
\hline & 89 & 4288 & $x$ & 0.06621 & 0.03024 & - & - & - & - & - \\
\hline & 90 & 4289 & $x$ & 0.01033 & 0.00632 & - & - & - & - & - \\
\hline & 91 & 4290 & $x$ & 0.04272 & 0.02133 & - & - & - & - & - \\
\hline & 92 & 4291 & $x$ & 0.02593 & 0.01335 & - & - & - & - & - \\
\hline & 93 & 4292 & $x$ & 0.00686 & 0.00576 & - & - & - & - & - \\
\hline \multirow[t]{4}{*}{ Lewis } & 94 & 4293 & $x$ & 0.33958 & 0.01118 & - & - & - & - & - \\
\hline & 95 & 4294 & $x$ & 0.02980 & 0.01438 & - & - & - & - & - \\
\hline & 96 & 4295 & $x$ & 0.09414 & 0.01199 & - & - & - & - & - \\
\hline & 97 & 4296 & $x$ & 0.02447 & 0.00979 & - & - & - & - & - \\
\hline \multirow[t]{6}{*}{$\begin{array}{l}\text { Lost } \\
\text { Creek }\end{array}$} & 98 & 4297 & $X$ & 0.50533 & 0.00924 & - & - & - & - & - \\
\hline & 99 & 4298 & $x$ & 0.04309 & 0.00977 & - & - & - & - & - \\
\hline & 100 & 4299 & $x$ & 0.00495 & 0.00656 & - & - & - & - & - \\
\hline & 101 & 4300 & $x$ & 0.01176 & 0.00891 & - & - & - & - & - \\
\hline & 102 & 4301 & $x$ & 0.02355 & 0.01106 & - & - & - & - & - \\
\hline & 103 & 4302 & $x$ & 0.02332 & 0.00860 & - & - & - & - & - \\
\hline Eugene & 104 & 4304 & $x$ & 0.08944 & 0.01769 & - & - & - & - & - \\
\hline \multirow[t]{8}{*}{ Carver } & 105 & 4306 & $x$ & 0.27911 & 0.06000 & - & - & - & - & - \\
\hline & 106 & 4307 & $x$ & 0.03190 & 0.01992 & - & - & - & - & - \\
\hline & 107 & 4308 & $x$ & 0.01955 & 0.00996 & - & - & - & - & - \\
\hline & 108 & 4309 & $x$ & 0.05121 & 0.04024 & - & - & - & - & - \\
\hline & 109 & 4310 & $x$ & 0.08319 & 0.03115 & - & - & - & - & - \\
\hline & 110 & 4311 & $x$ & 0.00918 & 0.00451 & - & - & - & - & - \\
\hline & 111 & 4329 & & 0.00569 & 0.00434 & - & - & - & - & - \\
\hline & 112 & 4348 & $x$ & 0.01618 & 0.01070 & - & - & - & - & - \\
\hline Hayden & 113 & 10518 & $x$ & 0.70938 & 0.00945 & - & - & - & - & - \\
\hline \multirow[t]{21}{*}{ Diller } & 114 & 10525 & $x$ & 0.50542 & 0.01789 & - & - & - & - & - \\
\hline & 115 & & & 0.00196 & 0.00269 & - & - & - & - & - \\
\hline & 116 & & & 0.00195 & 0.00188 & - & - & - & - & - \\
\hline & 117 & & & 0.00223 & 0.00307 & - & - & - & - & - \\
\hline & 118 & & & 0.00219 & 0.00192 & - & - & - & - & - \\
\hline & 119 & & & 0.00076 & 0.00122 & - & - & - & - & - \\
\hline & 120 & & $x$ & 0.01525 & 0.00713 & - & - & - & - & - \\
\hline & 121 & & $x$ & 0.02630 & 0.01954 & - & - & - & - & - \\
\hline & 122 & & $x$ & 0.00884 & 0.00994 & - & - & - & - & - \\
\hline & 123 & & $x$ & 0.00776 & 0.00461 & - & - & - & - & - \\
\hline & 124 & & $x$ & 0.01279 & 0.00574 & - & - & - & - & - \\
\hline & 125 & & $x$ & 0.01207 & 0.00429 & - & - & - & - & - \\
\hline & 126 & & $x$ & 0.01363 & 0.00629 & - & - & - & - & - \\
\hline & 127 & & $x$ & 0.00658 & 0.00453 & - & - & - & - & - \\
\hline & 128 & & & 0.00249 & 0.00225 & - & - & - & - & - \\
\hline & 129 & & & 0.00196 & 0.00180 & - & - & - & - & - \\
\hline & 130 & & $x$ & 0.00959 & 0.00901 & - & - & - & - & - \\
\hline & 131 & & & 0.00602 & 0.00555 & - & - & - & - & - \\
\hline & 132 & & & 0.00546 & 0.00356 & - & - & - & - & - \\
\hline & 133 & & & 0.00230 & 0.00227 & - & - & - & - & - \\
\hline & 134 & & & 0.00336 & 0.00429 & - & - & - & - & - \\
\hline
\end{tabular}




\begin{tabular}{|c|c|c|c|c|c|c|c|c|c|c|}
\hline $\begin{array}{l}\text { Glacier } \\
\text { Name }\end{array}$ & TS_ID & RECNO & Perennial & $\begin{array}{l}\text { Area } \\
\left(\mathrm{km}^{2}\right)\end{array}$ & $\begin{array}{l}\text { Uncertainty } \\
\left(\mathrm{km}^{2}\right)\end{array}$ & $S$ & Z & $Z \min$ & $Z \max$ & $\mathrm{D}$ \\
\hline & 135 & & & 0.00148 & 0.00188 & - & - & - & - & - \\
\hline & 136 & & $x$ & 0.01195 & 0.00512 & - & - & - & - & - \\
\hline & 137 & & $x$ & 0.00603 & 0.00417 & - & - & - & - & - \\
\hline & 138 & & & 0.00283 & 0.00307 & - & - & - & - & - \\
\hline & 139 & & $x$ & 0.00739 & 0.00747 & - & - & - & - & - \\
\hline & 140 & & & 0.00438 & 0.00372 & - & - & - & - & - \\
\hline & 141 & & $x$ & 0.01439 & 0.00644 & - & - & - & - & - \\
\hline & 142 & & & 0.00448 & 0.00341 & - & - & - & - & - \\
\hline & 143 & & & 0.00914 & 0.00669 & - & - & - & - & - \\
\hline & 144 & & & 0.00311 & 0.00258 & - & - & - & - & - \\
\hline & 145 & & & 0.00634 & 0.00478 & - & - & - & - & - \\
\hline & 146 & & $x$ & 0.02714 & 0.00783 & - & - & - & - & - \\
\hline & 147 & & & 0.00487 & 0.00286 & - & - & - & - & - \\
\hline & 148 & & & 0.00364 & 0.00257 & - & - & - & - & - \\
\hline & 149 & & & 0.02344 & 0.01188 & - & - & - & - & - \\
\hline & 150 & & $x$ & 0.00751 & 0.00710 & - & - & - & - & - \\
\hline & 151 & & & 0.00679 & 0.00386 & - & - & - & - & - \\
\hline & 152 & & & 0.01144 & 0.00625 & - & - & - & - & - \\
\hline & 153 & & & 0.00211 & 0.00195 & - & - & - & - & - \\
\hline & 154 & & & 0.00100 & 0.00264 & - & - & - & - & - \\
\hline & 155 & & & 0.00248 & 0.00307 & - & - & - & - & - \\
\hline & 156 & & & 0.00211 & 0.00302 & - & - & - & - & - \\
\hline & 157 & & & 0.00037 & 0.00092 & - & - & - & - & - \\
\hline & 158 & & & 0.00027 & 0.00109 & - & - & - & - & - \\
\hline & 159 & & & 0.00013 & 0.00052 & - & - & - & - & - \\
\hline & 160 & & & 0.00075 & 0.00146 & - & - & - & - & - \\
\hline & 161 & & & 0.00004 & 0.00031 & - & - & - & - & - \\
\hline & 162 & & & 0.00137 & 0.00272 & - & - & - & - & - \\
\hline & 163 & & & 0.00155 & 0.00245 & - & - & - & - & - \\
\hline & 164 & & & 0.00051 & 0.00194 & - & - & - & - & - \\
\hline & 165 & & & 0.00194 & 0.00250 & - & - & - & - & - \\
\hline & 166 & & & 0.00039 & 0.00092 & - & - & - & - & - \\
\hline & 167 & & $x$ & 0.01307 & 0.01157 & - & - & - & - & - \\
\hline & 168 & & $x$ & 0.00937 & 0.00734 & - & - & - & - & - \\
\hline & 169 & & & 0.00396 & 0.00418 & - & - & - & - & - \\
\hline & 170 & & & 0.00396 & 0.00378 & - & - & - & - & - \\
\hline & 171 & & & 0.00050 & 0.00086 & - & - & - & - & - \\
\hline & 172 & & & 0.00774 & 0.00534 & - & - & - & - & - \\
\hline & 173 & & & 0.00316 & 0.00280 & - & - & - & - & - \\
\hline & 174 & & & 0.00108 & 0.00224 & - & - & - & - & - \\
\hline & 175 & & & 0.00418 & 0.00562 & - & - & - & - & - \\
\hline & 176 & & & 0.00196 & 0.00233 & - & - & - & - & - \\
\hline & 177 & & & 0.00008 & 0.00052 & - & - & - & - & - \\
\hline & 178 & & & 0.00239 & 0.00305 & - & - & - & - & - \\
\hline & 179 & & & 0.00039 & 0.00117 & - & - & - & - & - \\
\hline & 180 & & & 0.00265 & 0.00310 & - & - & - & - & - \\
\hline & 181 & & & 0.00147 & 0.00256 & - & - & - & - & - \\
\hline & 182 & & & 0.00048 & 0.00109 & - & - & - & - & - \\
\hline
\end{tabular}




\begin{tabular}{|c|c|c|c|c|c|c|c|c|c|c|}
\hline $\begin{array}{l}\text { Glacier } \\
\text { Name }\end{array}$ & TS_ID & RECNO & Perennial & $\begin{array}{l}\text { Area } \\
\left(\mathrm{km}^{2}\right)\end{array}$ & $\begin{array}{l}\text { Uncertainty } \\
\left(\mathrm{km}^{2}\right)\end{array}$ & $S$ & Z & $Z \min$ & $Z \max$ & $\mathrm{D}$ \\
\hline & 183 & & & 0.00161 & 0.00361 & - & - & - & - & - \\
\hline & 184 & & & 0.00161 & 0.00182 & - & - & - & - & - \\
\hline & 185 & & $x$ & 0.00547 & 0.00494 & - & - & - & - & - \\
\hline & 186 & & & 0.00228 & 0.00320 & - & - & - & - & - \\
\hline & 187 & & & 0.00081 & 0.00231 & - & - & - & - & - \\
\hline & 188 & & & 0.00162 & 0.00254 & - & - & - & - & - \\
\hline & 189 & & & 0.00014 & 0.00059 & - & - & - & - & - \\
\hline & 190 & & & 0.00127 & 0.00161 & - & - & - & - & - \\
\hline & 191 & & & 0.00014 & 0.00047 & - & - & - & - & - \\
\hline & 192 & & & 0.00264 & 0.00339 & - & - & - & - & - \\
\hline & 193 & & & 0.00002 & 0.00024 & - & - & - & - & - \\
\hline & 194 & & $x$ & 0.00723 & 0.00965 & - & - & - & - & - \\
\hline & 195 & & & 0.00056 & 0.00090 & - & - & - & - & - \\
\hline & 196 & & & 0.00099 & 0.00146 & - & - & - & - & - \\
\hline & 197 & & $x$ & 0.01211 & 0.00841 & - & - & - & - & - \\
\hline & 198 & & & 0.00151 & 0.00210 & - & - & - & - & - \\
\hline & 199 & & & 0.00599 & 0.00373 & - & - & - & - & - \\
\hline & 200 & & & 0.00092 & 0.00162 & - & - & - & - & - \\
\hline & 201 & & & 0.00442 & 0.00552 & - & - & - & - & - \\
\hline & 202 & & & 0.00066 & 0.00127 & - & - & - & - & - \\
\hline & 203 & & & 0.00115 & 0.00208 & - & - & - & - & - \\
\hline & 204 & & & 0.00259 & 0.00248 & - & - & - & - & - \\
\hline & 205 & & & 0.00026 & 0.00072 & - & - & - & - & - \\
\hline & 206 & & & 0.00892 & 0.00782 & - & - & - & - & - \\
\hline & 207 & & & 0.00460 & 0.00581 & - & - & - & - & - \\
\hline & 208 & & & 0.00525 & 0.00427 & - & - & - & - & - \\
\hline & 209 & & & 0.00240 & 0.00267 & - & - & - & - & - \\
\hline & 210 & & & 0.00162 & 0.00319 & - & - & - & - & - \\
\hline & 211 & & & 0.00333 & 0.00477 & - & - & - & - & - \\
\hline & 212 & & & 0.00536 & 0.00579 & - & - & - & - & - \\
\hline & 213 & & $x$ & 0.00405 & 0.00551 & - & - & - & - & - \\
\hline & 214 & & & 0.00057 & 0.00094 & - & - & - & - & - \\
\hline & 215 & & & 0.00149 & 0.00197 & - & - & - & - & - \\
\hline & 216 & & & 0.00296 & 0.00494 & - & - & - & - & - \\
\hline & 217 & & & 0.00104 & 0.00143 & - & - & - & - & - \\
\hline & 218 & & & 0.00140 & 0.00205 & - & - & - & - & - \\
\hline & 219 & & & 0.00124 & 0.00140 & - & - & - & - & - \\
\hline & 220 & & & 0.00038 & 0.00107 & - & - & - & - & - \\
\hline & 221 & & & 0.00188 & 0.00306 & - & - & - & - & - \\
\hline & 222 & & & 0.00037 & 0.00136 & - & - & - & - & - \\
\hline & 223 & & & 0.00444 & 0.00487 & - & - & - & - & - \\
\hline & 224 & & & 0.00316 & 0.00319 & - & - & - & - & - \\
\hline & 225 & & & 0.00608 & 0.00710 & - & - & - & - & - \\
\hline & 226 & & & 0.00081 & 0.00129 & - & - & - & - & - \\
\hline & 227 & & $x$ & 0.01033 & 0.00880 & - & - & - & - & - \\
\hline & 228 & & & 0.00021 & 0.00057 & - & - & - & - & - \\
\hline & 229 & & & 0.00447 & 0.00600 & - & - & - & - & - \\
\hline & 230 & & & 0.00472 & 0.00681 & - & - & - & - & - \\
\hline
\end{tabular}




\begin{tabular}{|c|c|c|c|c|c|c|c|c|c|c|}
\hline $\begin{array}{l}\text { Glacier } \\
\text { Name }\end{array}$ & TS_ID & RECNO & Perennial & $\begin{array}{l}\text { Area } \\
\left(\mathrm{km}^{2}\right)\end{array}$ & $\begin{array}{l}\text { Uncertainty } \\
\left(\mathrm{km}^{2}\right)\end{array}$ & $S$ & Z & $Z \min$ & $Z \max$ & $\mathrm{D}$ \\
\hline & 231 & & & 0.00507 & 0.00563 & - & - & - & - & - \\
\hline & 232 & & & 0.00108 & 0.00145 & - & - & - & - & - \\
\hline & 233 & & & 0.00072 & 0.00138 & - & - & - & - & - \\
\hline & 234 & & & 0.00033 & 0.00114 & - & - & - & - & - \\
\hline & 235 & & & 0.00021 & 0.00071 & - & - & - & - & - \\
\hline & 236 & & & 0.00003 & 0.00043 & - & - & - & - & - \\
\hline & 237 & & & 0.00059 & 0.00101 & - & - & - & - & - \\
\hline & 238 & & & 0.00024 & 0.00093 & - & - & - & - & - \\
\hline & 239 & & & 0.00205 & 0.00226 & - & - & - & - & - \\
\hline & 240 & & & 0.00007 & 0.00033 & - & - & - & - & - \\
\hline & 241 & & & 0.00264 & 0.00599 & - & - & - & - & - \\
\hline & 242 & & & 0.00029 & 0.00136 & - & - & - & - & - \\
\hline & 243 & & & 0.00088 & 0.00155 & - & - & - & - & - \\
\hline & 244 & & & 0.00064 & 0.00102 & - & - & - & - & - \\
\hline & 245 & & & 0.00008 & 0.00038 & - & - & - & - & - \\
\hline & 246 & & & 0.00028 & 0.00079 & - & - & - & - & - \\
\hline & 247 & & $x$ & 0.00471 & 0.00281 & - & - & - & - & - \\
\hline & 248 & & & 0.00026 & 0.00075 & - & - & - & - & - \\
\hline & 249 & & & 0.00068 & 0.00173 & - & - & - & - & - \\
\hline & 250 & & & 0.00028 & 0.00095 & - & - & - & - & - \\
\hline & 251 & & & 0.00154 & 0.00279 & - & - & - & - & - \\
\hline & 252 & & & 0.00078 & 0.00115 & - & - & - & - & - \\
\hline & 253 & & & 0.00256 & 0.00233 & - & - & - & - & - \\
\hline & 254 & & & 0.00039 & 0.00082 & - & - & - & - & - \\
\hline & 255 & & & 0.00001 & 0.00020 & - & - & - & - & - \\
\hline & 256 & & & 0.00034 & 0.00092 & - & - & - & - & - \\
\hline & 257 & & & 0.00132 & 0.00246 & - & - & - & - & - \\
\hline & 258 & & & 0.00151 & 0.00170 & - & - & - & - & - \\
\hline & 259 & & & 0.00248 & 0.00270 & - & - & - & - & - \\
\hline & 260 & & & 0.00009 & 0.00058 & - & - & - & - & - \\
\hline & 261 & & & 0.00049 & 0.00151 & - & - & - & - & - \\
\hline & 262 & & & 0.00050 & 0.00116 & - & - & - & - & - \\
\hline & 263 & & & 0.00034 & 0.00104 & - & - & - & - & - \\
\hline & 264 & & & 0.00112 & 0.00132 & - & - & - & - & - \\
\hline & 265 & & & 0.00224 & 0.00234 & - & - & - & - & - \\
\hline & 266 & & & 0.00356 & 0.00505 & - & - & - & - & - \\
\hline & 267 & & & 0.00066 & 0.00120 & - & - & - & - & - \\
\hline & 268 & & & 0.01329 & 0.00877 & - & - & - & - & - \\
\hline & 269 & & & & 0.00000 & - & - & - & - & - \\
\hline & 270 & & & 0.00026 & 0.00072 & - & - & - & - & - \\
\hline & 271 & & & 0.00090 & 0.00134 & - & - & - & - & - \\
\hline & 272 & & & & 0.00000 & - & - & - & - & - \\
\hline & 273 & & & 0.00158 & 0.00164 & - & - & - & - & - \\
\hline & 274 & & & 0.00010 & 0.00050 & - & - & - & - & - \\
\hline & 275 & & & 0.00132 & 0.00274 & - & - & - & - & - \\
\hline & 276 & & & 0.00233 & 0.00234 & - & - & - & - & - \\
\hline & 277 & & & 0.00138 & 0.00286 & - & - & - & - & - \\
\hline & 278 & & & 0.00051 & 0.00139 & - & - & - & - & - \\
\hline
\end{tabular}




\begin{tabular}{|c|c|c|c|c|c|c|c|c|c|c|}
\hline $\begin{array}{l}\text { Glacier } \\
\text { Name }\end{array}$ & TS_ID & RECNO & Perennial & $\begin{array}{l}\text { Area } \\
\left(\mathrm{km}^{2}\right)\end{array}$ & $\begin{array}{l}\text { Uncertainty } \\
\left(\mathrm{km}^{2}\right)\end{array}$ & $S$ & Z & $Z \min$ & Zmax & $\mathrm{D}$ \\
\hline & 279 & & & 0.00087 & 0.00157 & - & - & - & - & - \\
\hline & 280 & & & 0.00017 & 0.00087 & - & - & - & - & - \\
\hline & 281 & & & 0.00032 & 0.00118 & - & - & - & - & - \\
\hline & 282 & & & 0.00001 & 0.00018 & - & - & - & - & - \\
\hline & 283 & & & 0.00075 & 0.00108 & - & - & - & - & - \\
\hline & 284 & & & 0.00090 & 0.00123 & - & - & - & - & - \\
\hline & 285 & & & 0.01881 & 0.01163 & - & - & - & - & - \\
\hline & 286 & & & 0.00250 & 0.00323 & - & - & - & - & - \\
\hline & 287 & & & 0.00626 & 0.00356 & - & - & - & - & - \\
\hline & 288 & & & 0.00091 & 0.00158 & - & - & - & - & - \\
\hline & 289 & & & 0.00012 & 0.00047 & - & - & - & - & - \\
\hline & 290 & & & 0.00177 & 0.00286 & - & - & - & - & - \\
\hline & 291 & & & 0.00797 & 0.00983 & - & - & - & - & - \\
\hline & 292 & & & 0.00106 & 0.00124 & - & - & - & - & - \\
\hline & 293 & & & 0.00079 & 0.00120 & - & - & - & - & - \\
\hline & 294 & & & 0.00177 & 0.00218 & - & - & - & - & - \\
\hline & 295 & & & 0.00077 & 0.00160 & - & - & - & - & - \\
\hline & 296 & & & 0.00331 & 0.00239 & - & - & - & - & - \\
\hline & 297 & & & 0.00396 & 0.00351 & - & - & - & - & - \\
\hline & 298 & & & 0.00056 & 0.00114 & - & - & - & - & - \\
\hline & 299 & & & 0.00171 & 0.00238 & - & - & - & - & - \\
\hline & 300 & & & 0.00126 & 0.00223 & - & - & - & - & - \\
\hline & 301 & & & 0.00842 & 0.00485 & - & - & - & - & - \\
\hline & 302 & & & 0.00159 & 0.00306 & - & - & - & - & - \\
\hline & 303 & & & 0.00449 & 0.00290 & - & - & - & - & - \\
\hline & 304 & & & 0.00013 & 0.00049 & - & - & - & - & - \\
\hline & 305 & & & 0.00006 & 0.00033 & - & - & - & - & - \\
\hline & 306 & & $x$ & 0.00383 & 0.00263 & - & - & - & - & - \\
\hline & 307 & & & 0.00029 & 0.00079 & - & - & - & - & - \\
\hline & 308 & & $x$ & 0.00467 & 0.00494 & - & - & - & - & - \\
\hline & 309 & & & 0.00128 & 0.00254 & - & - & - & - & - \\
\hline & 310 & & & 0.00347 & 0.00226 & - & - & - & - & - \\
\hline & 311 & & & 0.00109 & 0.00197 & - & - & - & - & - \\
\hline & 312 & & & 0.00018 & 0.00058 & - & - & - & - & - \\
\hline & 313 & & & 0.00357 & 0.00312 & - & - & - & - & - \\
\hline & 314 & & & 0.00175 & 0.00187 & - & - & - & - & - \\
\hline & 315 & & & 0.00693 & 0.00597 & - & - & - & - & - \\
\hline & 316 & & & 0.00095 & 0.00134 & - & - & - & - & - \\
\hline & 317 & & & 0.00074 & 0.00199 & - & - & - & - & - \\
\hline & 318 & & & 0.00219 & 0.00224 & - & - & - & - & - \\
\hline & 319 & & & 0.00064 & 0.00111 & - & - & - & - & - \\
\hline & 320 & & & 0.00099 & 0.00243 & - & - & - & - & - \\
\hline & 321 & & & 0.00480 & 0.00280 & - & - & - & - & - \\
\hline & 322 & & & 0.00745 & 0.00334 & - & - & - & - & - \\
\hline & 323 & & & 0.00057 & 0.00108 & - & - & - & - & - \\
\hline & 324 & & & 0.00474 & 0.00333 & - & - & - & - & - \\
\hline & 325 & & & 0.00458 & 0.00267 & - & - & - & - & - \\
\hline & 326 & & & 0.00363 & 0.00378 & - & - & - & - & - \\
\hline
\end{tabular}




\begin{tabular}{|c|c|c|c|c|c|c|c|c|c|c|}
\hline $\begin{array}{l}\text { Glacier } \\
\text { Name }\end{array}$ & TS_ID & RECNO & Perennial & $\begin{array}{l}\text { Area } \\
\left(\mathrm{km}^{2}\right)\end{array}$ & $\begin{array}{l}\text { Uncertainty } \\
\left(\mathrm{km}^{2}\right)\end{array}$ & $S$ & Z & $Z \min$ & $Z \max$ & $\mathrm{D}$ \\
\hline & 327 & & & 0.00361 & 0.00293 & - & - & - & - & - \\
\hline & 328 & & & 0.00292 & 0.00239 & - & - & - & - & - \\
\hline & 329 & & & 0.00211 & 0.00287 & - & - & - & - & - \\
\hline & 330 & & & 0.00098 & 0.00148 & - & - & - & - & - \\
\hline & 331 & & & 0.00134 & 0.00166 & - & - & - & - & - \\
\hline & 332 & & & 0.00341 & 0.00227 & - & - & - & - & - \\
\hline & 333 & & & 0.00702 & 0.00334 & - & - & - & - & - \\
\hline & 334 & & & 0.00364 & 0.00238 & - & - & - & - & - \\
\hline & 335 & & & 0.00681 & 0.00381 & - & - & - & - & - \\
\hline & 336 & & & 0.00139 & 0.00185 & - & - & - & - & - \\
\hline & 337 & & & 0.00020 & 0.00062 & - & - & - & - & - \\
\hline & 338 & & & 0.01115 & 0.00520 & - & - & - & - & - \\
\hline & 339 & & $x$ & 0.00372 & 0.00264 & - & - & - & - & - \\
\hline & 340 & & $x$ & 0.00897 & 0.00500 & - & - & - & - & - \\
\hline & 341 & & $x$ & 0.00713 & 0.00460 & - & - & - & - & - \\
\hline & 342 & & & 0.00110 & 0.00169 & - & - & - & - & - \\
\hline & 343 & & & 0.00126 & 0.00205 & - & - & - & - & - \\
\hline & 344 & & & 0.00070 & 0.00126 & - & - & - & - & - \\
\hline & 345 & & & 0.00219 & 0.00361 & - & - & - & - & - \\
\hline & 346 & & & 0.00104 & 0.00158 & - & - & - & - & - \\
\hline & 347 & & & 0.00248 & 0.00318 & - & - & - & - & - \\
\hline & 348 & & & 0.00096 & 0.00121 & - & - & - & - & - \\
\hline & 349 & & & 0.00093 & 0.00150 & - & - & - & - & - \\
\hline & 350 & & & 0.00068 & 0.00204 & - & - & - & - & - \\
\hline & 351 & & & 0.00086 & 0.00189 & - & - & - & - & - \\
\hline & 352 & & $x$ & 0.00818 & 0.00601 & - & - & - & - & - \\
\hline & 353 & & & 0.00308 & 0.00241 & - & - & - & - & - \\
\hline & 354 & & & 0.00095 & 0.00137 & - & - & - & - & - \\
\hline & 355 & & & 0.00106 & 0.00153 & - & - & - & - & - \\
\hline & 356 & & & 0.00182 & 0.00233 & - & - & - & - & - \\
\hline & 357 & & & 0.00094 & 0.00151 & - & - & - & - & - \\
\hline & 358 & & $x$ & 0.00923 & 0.00730 & - & - & - & - & - \\
\hline & 359 & & & 0.00134 & 0.00163 & - & - & - & - & - \\
\hline & 360 & & $x$ & 0.00377 & 0.00327 & - & - & - & - & - \\
\hline & 361 & & $x$ & 0.00648 & 0.00539 & - & - & - & - & - \\
\hline & 362 & & & 0.00488 & 0.00515 & - & - & - & - & - \\
\hline & 363 & & & 0.00234 & 0.00239 & - & - & - & - & - \\
\hline & 364 & & & 0.00132 & 0.00142 & - & - & - & - & - \\
\hline & 365 & & & 0.00106 & 0.00247 & - & - & - & - & - \\
\hline & 366 & & & 0.00672 & 0.00381 & - & - & - & - & - \\
\hline & 367 & & & 0.00100 & 0.00150 & - & - & - & - & - \\
\hline & 368 & & & 0.00094 & 0.00135 & - & - & - & - & - \\
\hline & 369 & & & 0.00061 & 0.00118 & - & - & - & - & - \\
\hline & 370 & & & 0.00340 & 0.00275 & - & - & - & - & - \\
\hline & 371 & & & 0.00059 & 0.00091 & - & - & - & - & - \\
\hline & 372 & & & & 0.00029 & - & - & - & - & - \\
\hline & 373 & & & 0.00004 & 0.00044 & - & - & - & - & - \\
\hline & 374 & & & 0.00001 & 0.00027 & - & - & - & - & - \\
\hline
\end{tabular}




\begin{tabular}{|c|c|c|c|c|c|c|c|c|c|c|}
\hline $\begin{array}{l}\text { Glacier } \\
\text { Name }\end{array}$ & TS_ID & RECNO & Perennial & $\begin{array}{l}\text { Area } \\
\left(\mathrm{km}^{2}\right)\end{array}$ & $\begin{array}{l}\text { Uncertainty } \\
\left(\mathrm{km}^{2}\right)\end{array}$ & $\mathrm{s}$ & z & $Z \min$ & $Z \max$ & D \\
\hline & 375 & & & 0.00020 & 0.00063 & - & - & - & - & - \\
\hline & 376 & & & 0.00221 & 0.00305 & - & - & - & - & - \\
\hline & 377 & & & 0.00063 & 0.00143 & - & - & - & - & - \\
\hline & 378 & & & 0.00058 & 0.00110 & - & - & - & - & - \\
\hline & 379 & & & 0.00463 & 0.00432 & - & - & - & - & - \\
\hline & 380 & & & 0.00454 & 0.00355 & - & - & - & - & - \\
\hline & 381 & & & 0.00019 & 0.00060 & - & - & - & - & - \\
\hline & 382 & & & 0.00001 & 0.00027 & - & - & - & - & - \\
\hline & 383 & & $x$ & 0.00305 & 0.00394 & - & - & - & - & - \\
\hline & 384 & & & 0.00226 & 0.00257 & - & - & - & - & - \\
\hline & 385 & & & 0.00221 & 0.00251 & - & - & - & - & - \\
\hline & 386 & & & 0.00001 & 0.00022 & - & - & - & - & - \\
\hline & 387 & & & 0.00660 & 0.00465 & - & - & - & - & - \\
\hline & 388 & & & 0.00020 & 0.00081 & - & - & - & - & - \\
\hline & 389 & & & 0.00206 & 0.00255 & - & - & - & - & - \\
\hline & 390 & & & 0.00000 & 0.00046 & - & - & - & - & - \\
\hline & 391 & & & 0.00175 & 0.00182 & - & - & - & - & - \\
\hline & 392 & & & 0.00022 & 0.00068 & - & - & - & - & - \\
\hline & 393 & & & 0.00021 & 0.00088 & - & - & - & - & - \\
\hline & 394 & & & 0.00010 & 0.00039 & - & - & - & - & - \\
\hline & 395 & & & 0.00020 & 0.00059 & - & - & - & - & - \\
\hline & 396 & & & 0.00144 & 0.00154 & - & - & - & - & - \\
\hline & 397 & & & 0.00042 & 0.00122 & - & - & - & - & - \\
\hline & 398 & & & 0.00004 & 0.00036 & - & - & - & - & - \\
\hline & 399 & & & 0.00057 & 0.00103 & - & - & - & - & - \\
\hline & 400 & & & 0.00161 & 0.00261 & - & - & - & - & - \\
\hline & 401 & & & 0.00045 & 0.00089 & - & - & - & - & - \\
\hline \multirow[t]{5}{*}{ ND } & 402 & & & & & - & - & - & - & - \\
\hline & 403 & & & 0.00059 & 0.00108 & - & - & - & - & - \\
\hline & 404 & & & 0.00059 & 0.00129 & - & - & - & - & - \\
\hline & 405 & & & 0.00053 & 0.00097 & - & - & - & - & - \\
\hline & 406 & & & 0.00010 & 0.00040 & - & - & - & - & - \\
\hline
\end{tabular}

1957

\begin{tabular}{|c|c|c|c|c|c|c|c|c|c|c|}
\hline $\begin{array}{l}\text { Glacier } \\
\text { Name }\end{array}$ & TS_ID & RECNO & Perennial & $\begin{array}{l}\text { Area } \\
\left(\mathrm{km}^{2}\right)\end{array}$ & $\begin{array}{c}\text { Uncertainty } \\
\left(\mathrm{km}^{2}\right)\end{array}$ & $\mathrm{s}$ & Z & $Z \min$ & $Z \max$ & D \\
\hline & 1 & & $x$ & 0.00634 & 0.00779 & 29.7 & 2416 & 2393 & 2447 & 191.3 \\
\hline & 2 & & & 0.00327 & 0.00606 & 20.2 & 2333 & 2317 & 2348 & 160.6 \\
\hline & 3 & & & 0.00496 & 0.00607 & 33.9 & 2747 & 2727 & 2772 & 206.8 \\
\hline & 4 & & $x$ & 0.00803 & 0.01133 & 29.3 & 2366 & 2344 & 2408 & 184.2 \\
\hline & 5 & & $x$ & 0.02702 & 0.02478 & 37.1 & 2270 & 2194 & 2353 & 313.3 \\
\hline & 6 & & $x$ & 0.00999 & 0.01820 & 53.8 & 2234 & 2202 & 2307 & 116.0 \\
\hline & 7 & & $x$ & 0.00385 & 0.00600 & 27.2 & 2361 & 2342 & 2381 & 315.6 \\
\hline & 8 & & $x$ & 0.03789 & 0.04485 & 30.1 & 2261 & 2211 & 2309 & 7.5 \\
\hline & 9 & & $x$ & 0.00940 & 0.01168 & 35.8 & 2382 & 2341 & 2421 & 354.8 \\
\hline & 10 & & $x$ & 0.00715 & 0.01325 & 28.9 & 2157 & 2132 & 2185 & 14.2 \\
\hline
\end{tabular}




\begin{tabular}{|c|c|c|c|c|c|c|c|c|c|c|}
\hline $\begin{array}{l}\text { Glacier } \\
\text { Name }\end{array}$ & TS_ID & RECNO & Perennial & $\begin{array}{l}\text { Area } \\
\left(\mathrm{km}^{2}\right)\end{array}$ & $\begin{array}{l}\text { Uncertainty } \\
\left(\mathrm{km}^{2}\right)\end{array}$ & $\mathrm{S}$ & Z & $Z \min$ & $Z \max$ & D \\
\hline & 11 & & $x$ & 0.00734 & 0.01062 & 23.8 & 2256 & 2227 & 2281 & 358.4 \\
\hline & 12 & & $x$ & 0.00383 & 0.00604 & 32.7 & 2168 & 2155 & 2188 & 2.3 \\
\hline & 13 & & & 0.00251 & 0.00489 & 45.4 & 2102 & 2075 & 2138 & 51.4 \\
\hline & 14 & & & 0.00087 & 0.00298 & 48.6 & 2200 & 2184 & 2214 & 82.2 \\
\hline & 15 & & & 0.02361 & 0.03200 & 23.4 & 2272 & 2216 & 2350 & 64.1 \\
\hline & 16 & & & 0.00250 & 0.00466 & 28.9 & 2796 & 2776 & 2813 & 260.7 \\
\hline & 17 & 4194 & $x$ & 0.00839 & 0.01231 & 49.4 & 2968 & 2862 & 3036 & 110.1 \\
\hline & 18 & 4196 & $x$ & 0.03733 & 0.06170 & 34.1 & 2744 & 2621 & 2868 & 249.2 \\
\hline & 19 & 4198 & $x$ & 0.02253 & 0.01816 & 49.6 & 2668 & 2561 & 2754 & 174.5 \\
\hline & 20 & 4201 & $x$ & 0.02594 & 0.01802 & 45.1 & 2728 & 2624 & 2859 & 155.7 \\
\hline & 21 & 4202 & $x$ & 0.00857 & 0.00707 & 37.8 & 2713 & 2676 & 2750 & 131.8 \\
\hline & 22 & 4204 & & 0.00053 & 0.00396 & 36.2 & 2376 & 2352 & 2405 & 93.3 \\
\hline & 23 & 4205 & $x$ & 0.01297 & 0.01894 & 36.4 & 2163 & 2132 & 2195 & 46.1 \\
\hline & 24 & 4206 & $x$ & 0.02813 & 0.02984 & 39.9 & 2394 & 2319 & 2466 & 317.6 \\
\hline \multirow[t]{2}{*}{ Renfrew } & 25 & 4207 & $x$ & 0.60392 & 0.16394 & 48.5 & 2623 & 2334 & 2827 & 296.8 \\
\hline & 26 & 4208 & $x$ & 0.15522 & 0.10271 & 38.1 & 2561 & 2365 & 2737 & 316.9 \\
\hline \multirow{7}{*}{ Collier } & 27 & 4209 & $x$ & 1.07415 & 0.15311 & 44.7 & 2483 & 2177 & 2722 & 349.0 \\
\hline & 28 & 4209 & $x$ & 0.19550 & 0.05730 & 36.8 & 2700 & 2598 & 2800 & 331.6 \\
\hline & 29 & 4210 & $x$ & 0.03796 & 0.01936 & 25.7 & 2563 & 2518 & 2584 & 266.6 \\
\hline & 30 & 4211 & $x$ & 0.04930 & 0.03486 & 37.6 & 2341 & 2309 & 2415 & 65.6 \\
\hline & 31 & 4212 & $x$ & 0.00769 & 0.00718 & 29.3 & 2298 & 2290 & 2309 & 110.8 \\
\hline & 32 & 4213 & & 0.00125 & 0.00808 & 29.5 & 2371 & 2336 & 2402 & 131.6 \\
\hline & 33 & 4214 & $x$ & 0.01278 & 0.01206 & 36.6 & 2275 & 2207 & 2344 & 130.4 \\
\hline \multirow[t]{10}{*}{ Thayer } & 34 & 4216 & $x$ & 0.12909 & 0.04330 & 53.9 & 2434 & 2340 & 2640 & 93.6 \\
\hline & 35 & 4217 & & 0.00145 & 0.00397 & 23.7 & 2149 & 2136 & 2160 & 108.4 \\
\hline & 36 & 4219 & $x$ & 0.00554 & 0.00791 & 31.5 & 2338 & 2316 & 2368 & 39.3 \\
\hline & 37 & 4220 & $x$ & 0.00895 & 0.01518 & 26.6 & 2318 & 2300 & 2341 & 311.5 \\
\hline & 38 & 4221 & $x$ & 0.01214 & 0.01598 & 31.0 & 2353 & 2310 & 2397 & 299.4 \\
\hline & 39 & 4222 & $x$ & 0.01282 & 0.02088 & 28.1 & 2470 & 2432 & 2516 & 279.4 \\
\hline & 40 & 4223 & $x$ & 0.00582 & 0.00749 & 21.9 & 2403 & 2382 & 2427 & 272.9 \\
\hline & 41 & 4224 & $x$ & 0.00526 & 0.01303 & 22.5 & 2434 & 2373 & 2487 & 286.8 \\
\hline & 42 & 4225 & $x$ & 0.00965 & 0.00887 & 30.4 & 2481 & 2457 & 2509 & 286.5 \\
\hline & 43 & 4226 & $x$ & 0.02012 & 0.02512 & 29.0 & 2311 & 2232 & 2393 & 308.3 \\
\hline Villard & 44 & 4227 & $x$ & 0.05423 & 0.00819 & 52.8 & 2773 & 2542 & 2935 & 51.0 \\
\hline \multirow[t]{15}{*}{ Linn } & 45 & 4228 & $x$ & 0.12710 & 0.01742 & 50.4 & 2507 & 2338 & 2727 & 7.1 \\
\hline & 46 & 4229 & & 0.03301 & 0.03488 & 36.5 & 2350 & 2256 & 2466 & 68.4 \\
\hline & 47 & 4233 & $x$ & 0.01777 & 0.01170 & 38.1 & 2340 & 2271 & 2422 & 336.3 \\
\hline & 48 & 4234 & $x$ & 0.02534 & 0.01615 & 41.0 & 2356 & 2301 & 2426 & 72.2 \\
\hline & 49 & 4237 & & 0.04287 & 0.02515 & 43.1 & 2354 & 2273 & 2507 & 21.2 \\
\hline & 50 & 4242 & & 0.00250 & 0.00432 & 29.7 & 2186 & 2182 & 2195 & 81.2 \\
\hline & 51 & 4243 & & 0.02776 & 0.02811 & 43.9 & 2144 & 2094 & 2196 & 58.9 \\
\hline & 52 & 4244 & $x$ & 0.03228 & 0.02412 & 30.8 & 2224 & 2187 & 2287 & 105.4 \\
\hline & 53 & 4245 & & 0.00965 & 0.00760 & 18.4 & 2236 & 2219 & 2253 & 358.8 \\
\hline & 54 & 4246 & & 0.00627 & 0.00724 & 32.7 & 2140 & 2107 & 2182 & 33.4 \\
\hline & 55 & 4247 & & 0.00540 & 0.00918 & 52.0 & 2071 & 2047 & 2122 & 357.3 \\
\hline & 56 & 4248 & & 0.00936 & 0.01168 & 25.3 & 2111 & 2092 & 2127 & 58.1 \\
\hline & 57 & 4250 & $x$ & 0.10638 & 0.06494 & 45.6 & 2345 & 2282 & 2408 & 78.8 \\
\hline & 59 & 4252 & $x$ & 0.04021 & 0.02896 & 31.3 & 2161 & 2131 & 2210 & 45.8 \\
\hline & & & & & & & & & & 125 \\
\hline
\end{tabular}




\begin{tabular}{|c|c|c|c|c|c|c|c|c|c|c|}
\hline $\begin{array}{l}\text { Glacier } \\
\text { Name }\end{array}$ & TS_ID & RECNO & Perennial & $\begin{array}{l}\text { Area } \\
\left(\mathrm{km}^{2}\right)\end{array}$ & $\begin{array}{c}\text { Uncertainty } \\
\left(\mathrm{km}^{2}\right)\end{array}$ & $\mathrm{S}$ & z & Zmin & $Z \max$ & D \\
\hline & 60 & 4254 & $x$ & 0.01043 & 0.01049 & 22.0 & 2319 & 2290 & 2339 & 172.3 \\
\hline & 61 & 4255 & $x$ & 0.01812 & 0.02781 & 32.6 & 2264 & 2221 & 2311 & 133.3 \\
\hline & 62 & 4256 & $x$ & 0.00739 & 0.01046 & 33.4 & 2460 & 2427 & 2499 & 183.0 \\
\hline & 63 & 4257 & $x$ & 0.00997 & 0.00955 & 9.8 & 2340 & 2337 & 2341 & 180.0 \\
\hline & 64 & 4258 & $x$ & 0.02243 & 0.01532 & 39.9 & 2300 & 2276 & 2330 & 319.4 \\
\hline & 66 & 4260 & $\mathrm{x}$ & 0.07921 & 0.07649 & 35.7 & 2402 & 2307 & 2496 & 179.6 \\
\hline \multirow[t]{6}{*}{ Irving } & 68 & 4262 & $x$ & 0.35687 & 0.11733 & 43.9 & 2347 & 2205 & 2591 & 127.3 \\
\hline & 69 & 4263 & $\mathrm{x}$ & 0.00881 & 0.00757 & 23.4 & 2359 & 2345 & 2373 & 155.8 \\
\hline & 70 & 4264 & $x$ & 0.07909 & 0.03585 & 27.9 & 2265 & 2207 & 2312 & 103.4 \\
\hline & 71 & 4265 & $x$ & 0.08399 & 0.05923 & 41.1 & 2272 & 2126 & 2438 & 115.4 \\
\hline & 72 & 4266 & $x$ & 0.04055 & 0.02377 & 32.1 & 2159 & 2120 & 2232 & 70.5 \\
\hline & 73 & 4268 & & 0.01875 & 0.01233 & & 2135 & 2093 & 2175 & 43.4 \\
\hline \multirow[t]{2}{*}{ Skinner } & 74 & 4270 & $x$ & 0.48067 & 0.12981 & 48.7 & 2469 & 2266 & 2751 & 349.6 \\
\hline & 75 & 4271 & $\mathrm{x}$ & 0.11408 & 0.04956 & 56.1 & 2614 & 2487 & 2884 & 29.1 \\
\hline \multirow[t]{6}{*}{ Prouty } & 76 & 4272 & $x$ & 1.16001 & 0.04195 & 68.2 & 2617 & 2386 & 2962 & 42.4 \\
\hline & 77 & 4273 & $x$ & 0.24446 & 0.11220 & 45.8 & 2393 & 2187 & 2618 & 88.0 \\
\hline & 78 & 4274 & $\mathrm{x}$ & 0.04360 & 0.02731 & 43.3 & 2551 & 2475 & 2663 & 85.8 \\
\hline & 80 & 4277 & $x$ & 0.01691 & 0.01588 & 32.4 & 2258 & 2207 & 2324 & 335.3 \\
\hline & 81 & 4278 & & & & & & & & \\
\hline & 82 & 4280 & $x$ & 0.01237 & 0.01546 & 39.8 & 2507 & 2439 & 2577 & 213.2 \\
\hline \multirow[t]{11}{*}{ Clark } & 83 & 4281 & $x$ & 0.34747 & 0.10671 & 42.1 & 2712 & 2519 & 2879 & 218.6 \\
\hline & 84 & 4282 & & 0.00535 & 0.00939 & 44.5 & 2567 & 2523 & 2601 & 155.3 \\
\hline & 85 & 4283 & $x$ & 0.02435 & 0.02974 & 42.5 & 2535 & 2467 & 2643 & 155.6 \\
\hline & 86 & 4284 & $x$ & 0.01151 & 0.00888 & 40.6 & 2369 & 2334 & 2412 & 100.2 \\
\hline & 87 & 4286 & $\mathrm{x}$ & 0.01270 & 0.01630 & 41.3 & 2346 & 2308 & 2400 & 1.4 \\
\hline & 88 & 4287 & $x$ & 0.04570 & 0.05536 & 47.7 & 2454 & 2319 & 2568 & 285.0 \\
\hline & 89 & 4288 & $x$ & 0.07936 & 0.05585 & 37.0 & 2469 & 2368 & 2564 & 312.4 \\
\hline & 90 & 4289 & $\mathrm{X}$ & 0.00698 & 0.01171 & 29.1 & 2437 & 2425 & 2462 & 227.3 \\
\hline & 91 & 4290 & $x$ & 0.05241 & 0.04282 & 39.0 & 2546 & 2472 & 2698 & 234.6 \\
\hline & 92 & 4291 & $\mathrm{x}$ & 0.02480 & 0.02816 & 40.0 & 2606 & 2545 & 2706 & 227.5 \\
\hline & 93 & 4292 & $x$ & 0.01077 & 0.01240 & 34.0 & 2635 & 2585 & 2666 & 237.8 \\
\hline \multirow[t]{4}{*}{ Lewis } & 94 & 4293 & $x$ & 0.41448 & 0.07740 & 50.6 & 2766 & 2605 & 3062 & 145.3 \\
\hline & 95 & 4294 & $\mathrm{x}$ & 0.02377 & 0.03411 & 43.7 & 3027 & 2944 & 3095 & 94.7 \\
\hline & 96 & 4295 & $\mathrm{X}$ & 0.09595 & 0.02413 & 31.3 & 3112 & 3097 & 3131 & 164.4 \\
\hline & 97 & 4296 & $x$ & 0.03263 & 0.02814 & 51.8 & 3085 & 3001 & 3148 & 60.3 \\
\hline \multirow[t]{6}{*}{$\begin{array}{l}\text { Lost } \\
\text { Creek }\end{array}$} & 98 & 4297 & $x$ & 0.56058 & 0.08497 & 56.3 & 2545 & 2274 & 2811 & 324.6 \\
\hline & 99 & 4298 & $\mathrm{x}$ & 0.04356 & 0.01952 & 46.0 & 2744 & 2670 & 2864 & 100.6 \\
\hline & 100 & 4299 & $x$ & 0.00428 & 0.01187 & 48.1 & 2462 & 2360 & 2535 & 58.2 \\
\hline & 101 & 4300 & $\mathrm{X}$ & 0.00369 & 0.00995 & 26.3 & 2285 & 2250 & 2315 & 306.9 \\
\hline & 102 & 4301 & $x$ & 0.01965 & 0.02021 & 42.8 & 2329 & 2242 & 2398 & 313.8 \\
\hline & 103 & 4302 & $x$ & 0.01751 & 0.01426 & 42.1 & 2415 & 2356 & 2465 & 300.6 \\
\hline Eugene & 104 & 4304 & $x$ & 0.11740 & 0.03701 & 48.2 & 2522 & 2436 & 2626 & 344.8 \\
\hline \multirow[t]{5}{*}{ Carver } & 105 & 4306 & $\mathrm{X}$ & 0.31267 & 0.11985 & 37.4 & 2328 & 2199 & 2547 & 15.9 \\
\hline & 106 & 4307 & $x$ & 0.02376 & 0.03231 & 37.2 & 2246 & 2196 & 2302 & 333.0 \\
\hline & 107 & 4308 & $x$ & 0.02673 & 0.02130 & 39.8 & 2356 & 2282 & 2425 & 334.4 \\
\hline & 108 & 4309 & $x$ & 0.08680 & 0.05953 & 53.0 & 2344 & 2199 & 2451 & 27.3 \\
\hline & 109 & 4310 & $x$ & 0.07328 & 0.05290 & 29.5 & 2301 & 2230 & 2354 & 68.9 \\
\hline
\end{tabular}




\begin{tabular}{|c|c|c|c|c|c|c|c|c|c|c|}
\hline $\begin{array}{c}\text { Glacier } \\
\text { Name }\end{array}$ & TS_ID & RECNO & Perennial & $\begin{array}{l}\text { Area } \\
\left(\mathrm{km}^{2}\right)\end{array}$ & $\begin{array}{c}\text { Uncertainty } \\
\left(\mathrm{km}^{2}\right)\end{array}$ & $\mathrm{s}$ & Z & Zmin & $Z \max$ & D \\
\hline & 110 & 4311 & $x$ & 0.00685 & 0.00719 & 24.5 & 2443 & 2427 & 2459 & 114.7 \\
\hline & 111 & 4329 & & 0.00289 & 0.00711 & 30.5 & 2268 & 2247 & 2285 & 30.2 \\
\hline & 112 & 4348 & $x$ & 0.02561 & 0.02365 & 40.7 & 2347 & 2272 & 2415 & 69.6 \\
\hline Hayden & 113 & 10518 & $x$ & 0.77649 & 0.10085 & 61.1 & 2592 & 2314 & 2835 & 90.4 \\
\hline \multirow[t]{44}{*}{ Diller } & 114 & 10525 & $x$ & 0.58848 & 0.01689 & 53.3 & 2496 & 2291 & 2748 & 81.9 \\
\hline & 115 & & & 0.00087 & 0.00230 & 17.2 & 2293 & 2287 & 2300 & 179.8 \\
\hline & 116 & & & 0.00021 & 0.00151 & 22.3 & 2278 & 2270 & 2284 & 148.5 \\
\hline & 117 & & & 0.00001 & 0.00149 & 9.4 & 2263 & 2259 & 2266 & 230.2 \\
\hline & 118 & & & 0.00015 & 0.00100 & 6.1 & 2258 & 2256 & 2259 & 190.6 \\
\hline & 119 & & & 0.00029 & 0.00029 & 7.8 & 2254 & 2254 & 2254 & 176.0 \\
\hline & 120 & & $x$ & 0.00556 & 0.01312 & 29.7 & 2386 & 2360 & 2441 & 241.4 \\
\hline & 121 & & $x$ & 0.02121 & 0.03054 & 28.5 & 2361 & 2310 & 2420 & 257.4 \\
\hline & 122 & & $x$ & 0.01080 & 0.02125 & 35.8 & 2479 & 2403 & 2580 & 265.4 \\
\hline & 123 & & $x$ & 0.00193 & 0.00605 & 26.8 & 2308 & 2293 & 2325 & 252.0 \\
\hline & 124 & & $x$ & 0.01688 & 0.01110 & 40.7 & 2128 & 2100 & 2187 & 354.7 \\
\hline & 125 & & $x$ & 0.01703 & 0.01179 & 52.2 & 2926 & 2830 & 3000 & 322.5 \\
\hline & 126 & & $x$ & 0.01502 & 0.01152 & 38.8 & 2485 & 2453 & 2517 & 307.7 \\
\hline & 127 & & $x$ & 0.00660 & 0.00811 & 39.3 & 2470 & 2450 & 2502 & 242.8 \\
\hline & 128 & & & 0.00121 & 0.00501 & 30.8 & 2434 & 2419 & 2446 & 240.4 \\
\hline & 129 & & & 0.00166 & 0.00341 & 33.7 & 2544 & 2523 & 2558 & 170.4 \\
\hline & 130 & & $x$ & 0.00925 & 0.01304 & 43.8 & 2323 & 2296 & 2371 & 324.5 \\
\hline & 131 & & & 0.00270 & 0.01173 & 33.9 & 2418 & 2391 & 2444 & 294.8 \\
\hline & 132 & & & 0.00132 & 0.00506 & 41.8 & 2407 & 2372 & 2451 & 182.6 \\
\hline & 133 & & & 0.00071 & 0.00298 & 31.1 & 2364 & 2355 & 2378 & 227.9 \\
\hline & 134 & & & 0.00152 & 0.00578 & 37.0 & 2448 & 2404 & 2494 & 190.4 \\
\hline & 135 & & & 0.00074 & 0.00279 & 24.5 & 2446 & 2430 & 2462 & 200.5 \\
\hline & 136 & & $x$ & 0.01080 & 0.01176 & 37.1 & 2733 & 2659 & 2793 & 276.8 \\
\hline & 137 & & $x$ & 0.00387 & 0.00670 & 35.5 & 2523 & 2496 & 2552 & 280.7 \\
\hline & 138 & & & 0.00077 & 0.00365 & 24.2 & 2457 & 2444 & 2475 & 293.8 \\
\hline & 139 & & $x$ & 0.00167 & 0.00854 & 38.9 & 2346 & 2317 & 2384 & 310.6 \\
\hline & 140 & & & 0.00102 & 0.00358 & 34.1 & 2300 & 2280 & 2319 & 309.1 \\
\hline & 141 & & $x$ & 0.00925 & 0.01100 & 27.1 & 2107 & 2093 & 2128 & 61.7 \\
\hline & 142 & & & 0.00306 & 0.00585 & 21.2 & 2166 & 2147 & 2191 & 84.1 \\
\hline & 143 & & & 0.00199 & 0.00660 & 17.7 & 2091 & 2080 & 2108 & 72.5 \\
\hline & 144 & & & 0.00098 & 0.00267 & 24.1 & 2107 & 2097 & 2120 & 14.4 \\
\hline & 145 & & & 0.00115 & 0.00416 & 27.0 & 2110 & 2097 & 2126 & 32.2 \\
\hline & 146 & & $x$ & 0.01978 & 0.01549 & 16.7 & 2080 & 2075 & 2085 & 42.6 \\
\hline & 147 & & & 0.00061 & 0.00233 & 15.2 & 2116 & 2109 & 2123 & 73.7 \\
\hline & 148 & & & 0.00164 & 0.00376 & 32.5 & 2145 & 2132 & 2159 & 91.2 \\
\hline & 149 & & & 0.01767 & 0.02088 & 39.0 & 2211 & 2165 & 2259 & 65.9 \\
\hline & 150 & & $x$ & 0.00680 & 0.01065 & 22.0 & 2360 & 2348 & 2373 & 57.9 \\
\hline & 151 & & & 0.00477 & 0.00681 & 25.9 & 2231 & 2217 & 2261 & 56.4 \\
\hline & 152 & & & & & & & & & \\
\hline & 153 & & & 0.00083 & 0.00235 & 18.4 & 2280 & 2276 & 2286 & 263.9 \\
\hline & 154 & & & 0.00079 & 0.00357 & 26.1 & 2292 & 2266 & 2314 & 308.3 \\
\hline & 155 & & & 0.00114 & 0.00411 & 21.5 & 2267 & 2250 & 2289 & 295.0 \\
\hline & 156 & & & 0.00067 & 0.00448 & 22.4 & 2328 & 2293 & 2364 & 276.9 \\
\hline & 157 & & & 0.00080 & 0.00080 & 23.3 & 2259 & 2251 & 2267 & 268.7 \\
\hline
\end{tabular}




\begin{tabular}{|c|c|c|c|c|c|c|c|c|c|c|}
\hline $\begin{array}{l}\text { Glacier } \\
\text { Name }\end{array}$ & TS_ID & RECNO & Perennial & $\begin{array}{l}\text { Area } \\
\left(\mathrm{km}^{2}\right)\end{array}$ & $\begin{array}{l}\text { Uncertainty } \\
\left(\mathrm{km}^{2}\right)\end{array}$ & $\mathrm{S}$ & Z & Zmin & $Z \max$ & $\mathrm{D}$ \\
\hline & 158 & & & 0.00041 & 0.00041 & 21.8 & 2397 & 2395 & 2399 & 258.4 \\
\hline & 159 & & & 0.00045 & 0.00045 & 16.7 & 2399 & 2397 & 2403 & 290.2 \\
\hline & 160 & & & 0.00003 & 0.00132 & 19.2 & 2375 & 2366 & 2385 & 280.3 \\
\hline & 161 & & & 0.00023 & 0.00023 & 19.8 & 2359 & 2359 & 2359 & 272.7 \\
\hline & 162 & & & 0.00139 & 0.00501 & 26.7 & 2340 & 2314 & 2372 & 289.1 \\
\hline & 163 & & & 0.00087 & 0.00087 & 24.3 & 2213 & 2201 & 2218 & 285.8 \\
\hline & 164 & & & 0.00020 & 0.00288 & 26.7 & 2234 & 2206 & 2271 & 313.9 \\
\hline & 165 & & & 0.00009 & 0.00174 & 29.0 & 2185 & 2179 & 2198 & 326.1 \\
\hline & 166 & & & 0.00024 & 0.00024 & 6.5 & 2172 & 2172 & 2173 & 326.0 \\
\hline & 167 & & $x$ & 0.00312 & 0.00949 & 35.9 & 2224 & 2160 & 2286 & 330.8 \\
\hline & 168 & & $x$ & 0.00242 & 0.00623 & 25.6 & 2148 & 2132 & 2160 & 10.5 \\
\hline & 169 & & & 0.00088 & 0.00460 & 33.6 & 2157 & 2136 & 2191 & 323.7 \\
\hline & 170 & & & 0.00001 & 0.00189 & 24.9 & 2181 & 2158 & 2201 & 284.5 \\
\hline & 171 & & & 0.00007 & 0.00083 & 18.9 & 2298 & 2295 & 2302 & 341.1 \\
\hline & 172 & & & 0.00370 & 0.00807 & 37.6 & 2333 & 2305 & 2355 & 10.0 \\
\hline & 173 & & & 0.00083 & 0.00326 & 24.8 & 2226 & 2203 & 2242 & 286.0 \\
\hline & 174 & & & 0.00009 & 0.00214 & 32.4 & 2217 & 2191 & 2238 & 296.1 \\
\hline & 175 & & & 0.00119 & 0.00119 & 30.8 & 2183 & 2135 & 2219 & 313.0 \\
\hline & 176 & & & 0.00126 & 0.00126 & 21.9 & 2249 & 2243 & 2255 & 325.5 \\
\hline & 177 & & & 0.00030 & 0.00030 & 22.6 & 2279 & 2278 & 2281 & 250.7 \\
\hline & 178 & & & 0.00003 & 0.00225 & 27.4 & 2240 & 2228 & 2258 & 263.1 \\
\hline & 179 & & & 0.00004 & 0.00136 & 24.1 & 2196 & 2184 & 2207 & 253.9 \\
\hline & 180 & & & 0.00036 & 0.00275 & 22.8 & 2179 & 2163 & 2197 & 297.3 \\
\hline & 181 & & & 0.00011 & 0.00166 & 25.4 & 2260 & 2242 & 2276 & 280.8 \\
\hline & 182 & & & 0.00000 & 0.00050 & 15.4 & 2172 & 2170 & 2174 & 308.1 \\
\hline & 183 & & & 0.00041 & 0.00450 & 30.4 & 2272 & 2235 & 2320 & 261.2 \\
\hline & 184 & & & 0.00470 & 0.01092 & 34.4 & 2439 & 2375 & 2503 & 281.5 \\
\hline & 185 & & $x$ & 0.00139 & 0.00611 & 39.1 & 2471 & 2405 & 2565 & 289.4 \\
\hline & 186 & & & 0.00100 & 0.00100 & 17.6 & 2213 & 2206 & 2219 & 318.6 \\
\hline & 187 & & & 0.00080 & 0.00080 & 20.3 & 2183 & 2172 & 2192 & 255.6 \\
\hline & 188 & & & 0.00006 & 0.00135 & 23.9 & 2210 & 2199 & 2230 & 264.0 \\
\hline & 189 & & & 0.00000 & 0.00068 & 17.5 & 2211 & 2206 & 2215 & 269.1 \\
\hline & 190 & & & 0.00060 & 0.00207 & 22.8 & 2204 & 2197 & 2213 & 284.0 \\
\hline & 191 & & & 0.00002 & 0.00061 & 33.1 & 2244 & 2239 & 2250 & 291.2 \\
\hline & 192 & & & 0.00071 & 0.00363 & 27.0 & 2304 & 2281 & 2328 & 271.6 \\
\hline & 193 & & & 0.00000 & 0.00045 & 24.0 & 2314 & 2310 & 2318 & 285.5 \\
\hline & 194 & & $x$ & 0.00475 & 0.01435 & 26.7 & 2292 & 2259 & 2331 & 277.8 \\
\hline & 195 & & & 0.00012 & 0.00091 & 17.8 & 2256 & 2251 & 2260 & 267.9 \\
\hline & 196 & & & 0.00039 & 0.00198 & 21.3 & 2377 & 2369 & 2384 & 213.5 \\
\hline & 197 & & $x$ & 0.00329 & 0.01156 & 25.4 & 2365 & 2344 & 2396 & 241.9 \\
\hline & 198 & & & 0.00008 & 0.00088 & 19.6 & 2281 & 2277 & 2284 & 262.7 \\
\hline & 199 & & & 0.00000 & 0.00085 & 12.3 & 2296 & 2293 & 2299 & 232.2 \\
\hline & 200 & & & 0.00001 & 0.00069 & 10.0 & 2277 & 2275 & 2279 & 282.5 \\
\hline & 201 & & & 0.00006 & 0.00137 & 8.9 & 2285 & 2280 & 2290 & 270.8 \\
\hline & 202 & & & 0.00008 & 0.00090 & 14.9 & 2312 & 2308 & 2314 & 302.9 \\
\hline & 203 & & & 0.00014 & 0.00150 & 13.1 & 2321 & 2316 & 2325 & 207.6 \\
\hline & 204 & & & 0.00009 & 0.00206 & 24.3 & 2285 & 2280 & 2295 & 202.9 \\
\hline & 205 & & & 0.00005 & 0.00104 & 11.1 & 2225 & 2223 & 2227 & 222.4 \\
\hline
\end{tabular}




\begin{tabular}{|c|c|c|c|c|c|c|c|c|c|c|}
\hline $\begin{array}{l}\text { Glacier } \\
\text { Name }\end{array}$ & TS_ID & RECNO & Perennial & $\begin{array}{l}\text { Area } \\
\left(\mathrm{km}^{2}\right)\end{array}$ & $\begin{array}{l}\text { Uncertainty } \\
\left(\mathrm{km}^{2}\right)\end{array}$ & $S$ & Z & $Z \min$ & $Z \max$ & D \\
\hline & 206 & & & 0.00119 & 0.00319 & 18.7 & 2200 & 2191 & 2205 & 342.4 \\
\hline & 207 & & & 0.00291 & 0.00860 & 41.8 & 2254 & 2192 & 2317 & 326.1 \\
\hline & 208 & & & 0.00112 & 0.00417 & 35.7 & 2232 & 2193 & 2251 & 332.3 \\
\hline & 209 & & & 0.00001 & 0.00150 & 30.8 & 2196 & 2183 & 2213 & 332.7 \\
\hline & 210 & & & 0.00010 & 0.00265 & 25.2 & 2220 & 2197 & 2244 & 309.5 \\
\hline & 211 & & & 0.00060 & 0.00355 & 32.2 & 2206 & 2185 & 2235 & 326.4 \\
\hline & 212 & & & 0.00031 & 0.00342 & 30.4 & 2221 & 2171 & 2254 & 328.0 \\
\hline & 213 & & $x$ & 0.00122 & 0.00702 & 28.9 & 2283 & 2225 & 2325 & 311.0 \\
\hline & 214 & & & 0.00012 & 0.00101 & 25.6 & 2342 & 2336 & 2350 & 299.3 \\
\hline & 215 & & & 0.00050 & 0.00244 & 25.3 & 2345 & 2334 & 2361 & 290.7 \\
\hline & 216 & & & 0.00024 & 0.00249 & 26.8 & 2214 & 2199 & 2247 & 332.7 \\
\hline & 217 & & & 0.00038 & 0.00187 & 25.7 & 2265 & 2254 & 2273 & 339.8 \\
\hline & 218 & & & 0.00029 & 0.00214 & 30.7 & 2249 & 2240 & 2267 & 310.8 \\
\hline & 219 & & & 0.00038 & 0.00155 & 32.4 & 2252 & 2242 & 2268 & 315.2 \\
\hline & 220 & & & 0.00115 & 0.00115 & 33.9 & 2226 & 2212 & 2244 & 298.3 \\
\hline & 221 & & & 0.00160 & 0.00499 & 31.7 & 2347 & 2325 & 2363 & 308.5 \\
\hline & 222 & & & 0.00041 & 0.00041 & 22.3 & 2303 & 2300 & 2306 & 271.0 \\
\hline & 223 & & & 0.00095 & 0.00420 & 31.0 & 2285 & 2276 & 2293 & 302.5 \\
\hline & 224 & & & 0.00168 & 0.00513 & 30.1 & 2364 & 2354 & 2376 & 208.5 \\
\hline & 225 & & & 0.00003 & 0.00433 & 32.2 & 2390 & 2363 & 2426 & 250.1 \\
\hline & 226 & & & 0.00137 & 0.00358 & 18.5 & 2564 & 2557 & 2572 & 206.1 \\
\hline & 227 & & $x$ & 0.00119 & 0.00627 & 29.3 & 2386 & 2350 & 2418 & 184.0 \\
\hline & 228 & & & 0.00016 & 0.00095 & 32.2 & 2448 & 2441 & 2454 & 201.8 \\
\hline & 229 & & & 0.00108 & 0.00801 & 29.1 & 2369 & 2334 & 2409 & 218.9 \\
\hline & 230 & & & 0.00220 & 0.00817 & 28.7 & 2370 & 2320 & 2417 & 164.2 \\
\hline & 231 & & & 0.00017 & 0.00224 & 23.2 & 2304 & 2287 & 2318 & 126.8 \\
\hline & 232 & & & 0.00016 & 0.00111 & 15.5 & 2348 & 2344 & 2352 & 133.8 \\
\hline & 233 & & & 0.00013 & 0.00125 & 19.8 & 2361 & 2356 & 2365 & 153.5 \\
\hline & 234 & & & 0.00062 & 0.00273 & 30.2 & 2448 & 2435 & 2469 & 201.9 \\
\hline & 235 & & & 0.00009 & 0.00107 & 29.0 & 2427 & 2415 & 2438 & 213.0 \\
\hline & 236 & & & 0.00000 & 0.00110 & 37.5 & 2436 & 2425 & 2444 & 225.6 \\
\hline & 237 & & & 0.00032 & 0.00169 & 18.1 & 2449 & 2441 & 2457 & 177.0 \\
\hline & 238 & & & 0.00412 & 0.00857 & 41.4 & 2660 & 2629 & 2694 & 177.4 \\
\hline & 239 & & & 0.00309 & 0.00897 & 26.4 & 2436 & 2409 & 2467 & 138.1 \\
\hline & 240 & & & 0.00033 & 0.00187 & 25.3 & 2473 & 2459 & 2486 & 153.0 \\
\hline & 241 & & & 0.00131 & 0.00842 & 32.1 & 2148 & 2120 & 2182 & 71.1 \\
\hline & 242 & & & 0.00027 & 0.00295 & 18.9 & 2172 & 2158 & 2188 & 161.9 \\
\hline & 243 & & & 0.00055 & 0.00224 & 25.8 & 2245 & 2234 & 2256 & 93.0 \\
\hline & 244 & & & 0.00072 & 0.00346 & 30.7 & 2210 & 2189 & 2232 & 139.4 \\
\hline & 245 & & & 0.00055 & 0.00055 & 30.2 & 2206 & 2200 & 2212 & 121.4 \\
\hline & 246 & & & 0.00003 & 0.00109 & 27.9 & 2234 & 2223 & 2243 & 118.8 \\
\hline & 247 & & $x$ & 0.00310 & 0.00483 & 40.1 & 2301 & 2284 & 2326 & 154.7 \\
\hline & 248 & & & 0.00035 & 0.00171 & 26.7 & 2338 & 2327 & 2348 & 154.4 \\
\hline & 249 & & & 0.00046 & 0.00271 & 34.9 & 2386 & 2361 & 2413 & 165.8 \\
\hline & 250 & & & 0.00081 & 0.00352 & 35.6 & 2483 & 2462 & 2502 & 37.7 \\
\hline & 251 & & & 0.00175 & 0.00574 & 30.5 & 2433 & 2415 & 2458 & 39.5 \\
\hline & 252 & & & 0.00099 & 0.00246 & 23.5 & 2258 & 2252 & 2267 & 53.7 \\
\hline \multirow{2}{*}{\multicolumn{2}{|c|}{253}} & & & 0.00085 & 0.00318 & 36.9 & 2222 & 2205 & 2242 & 85.6 \\
\hline & & & & & & & & & & 129 \\
\hline
\end{tabular}




\begin{tabular}{|c|c|c|c|c|c|c|c|c|c|c|}
\hline $\begin{array}{l}\text { Glacier } \\
\text { Name }\end{array}$ & TS_ID & RECNO & Perennial & $\begin{array}{l}\text { Area } \\
\left(\mathrm{km}^{2}\right)\end{array}$ & $\begin{array}{l}\text { Uncertainty } \\
\left(\mathrm{km}^{2}\right)\end{array}$ & $\mathrm{S}$ & Z & Zmin & $Z \max$ & $\mathrm{D}$ \\
\hline & 254 & & & 0.00001 & 0.00052 & 28.7 & 2267 & 2263 & 2271 & 55.7 \\
\hline & 255 & & & 0.00033 & 0.00033 & 22.3 & 2263 & 2260 & 2267 & 73.7 \\
\hline & 256 & & & 0.00041 & 0.00041 & 21.7 & 2256 & 2255 & 2259 & 82.6 \\
\hline & 257 & & & 0.00021 & 0.00211 & 35.0 & 2309 & 2284 & 2344 & 90.0 \\
\hline & 258 & & & 0.00082 & 0.00263 & 34.1 & 2174 & 2161 & 2191 & 67.0 \\
\hline & 259 & & & 0.00230 & 0.00501 & 35.1 & 2481 & 2448 & 2514 & 110.3 \\
\hline & 260 & & & 0.00075 & 0.00075 & 32.8 & 2422 & 2414 & 2432 & 142.1 \\
\hline & 261 & & & 0.00003 & 0.00194 & 25.0 & 2327 & 2309 & 2345 & 57.6 \\
\hline & 262 & & & 0.00053 & 0.00222 & 35.9 & 2409 & 2397 & 2420 & 46.6 \\
\hline & 263 & & & 0.00043 & 0.00232 & 26.0 & 2373 & 2360 & 2388 & 38.4 \\
\hline & 264 & & & 0.00052 & 0.00181 & 20.1 & 2352 & 2344 & 2361 & 41.5 \\
\hline & 265 & & & 0.00074 & 0.00287 & 30.3 & 2354 & 2342 & 2367 & 78.1 \\
\hline & 266 & & & 0.00240 & 0.00784 & 38.6 & 2282 & 2258 & 2309 & 21.5 \\
\hline & 267 & & & 0.00010 & 0.00118 & 34.5 & 2450 & 2438 & 2465 & 87.8 \\
\hline & 268 & & & 0.00771 & 0.01467 & 38.2 & 2344 & 2261 & 2412 & 69.4 \\
\hline & 269 & & & 0.02479 & 0.00000 & & & & & \\
\hline & 270 & & & 0.00008 & 0.00170 & 32.3 & 2671 & 2654 & 2689 & 42.4 \\
\hline & 271 & & & 0.00023 & 0.00153 & 21.6 & 2758 & 2753 & 2765 & 34.8 \\
\hline & 272 & & & 0.00184 & 0.00000 & & & & & \\
\hline & 273 & & & 0.00106 & 0.00274 & 28.7 & 2214 & 2201 & 2228 & 46.8 \\
\hline & 274 & & & 0.00049 & 0.00049 & 35.6 & 2187 & 2182 & 2194 & 82.7 \\
\hline & 275 & & & 0.00044 & 0.00362 & 34.2 & 2243 & 2216 & 2270 & 49.8 \\
\hline & 276 & & & 0.00308 & 0.00541 & 23.4 & 2293 & 2278 & 2305 & 104.8 \\
\hline & 277 & & & 0.00060 & 0.00381 & 25.9 & 2278 & 2262 & 2297 & 92.3 \\
\hline & 278 & & & 0.00025 & 0.00187 & 17.2 & 2244 & 2239 & 2254 & 67.0 \\
\hline & 279 & & & 0.00010 & 0.00149 & 25.0 & 2272 & 2264 & 2281 & 101.1 \\
\hline & 280 & & & 0.00082 & 0.00343 & 30.1 & 2359 & 2336 & 2379 & 74.4 \\
\hline & 281 & & & 0.00132 & 0.00509 & 24.3 & 2363 & 2351 & 2378 & 56.6 \\
\hline & 282 & & & 0.00007 & 0.00088 & 23.9 & 2421 & 2415 & 2428 & 65.0 \\
\hline & 283 & & & 0.00063 & 0.00192 & 24.2 & 2229 & 2223 & 2236 & 112.3 \\
\hline & 284 & & & 0.00044 & 0.00165 & 9.9 & 2230 & 2229 & 2231 & 92.7 \\
\hline & 285 & & & 0.00487 & 0.01127 & 30.0 & 2188 & 2154 & 2218 & 36.1 \\
\hline & 286 & & & 0.00013 & 0.00288 & & 2131 & 2108 & 2147 & 18.8 \\
\hline & 287 & & & 0.00170 & 0.00578 & & 2167 & 2146 & 2188 & 43.8 \\
\hline & 288 & & & 0.00024 & 0.00168 & 17.3 & 2229 & 2224 & 2235 & 330.3 \\
\hline & 289 & & & 0.00052 & 0.00052 & 9.7 & 2130 & 2130 & 2132 & 84.9 \\
\hline & 290 & & & 0.00022 & 0.00143 & 25.9 & 2089 & 2079 & 2098 & 353.6 \\
\hline & 291 & & & 0.00013 & 0.00211 & 33.5 & 2036 & 2031 & 2045 & 33.2 \\
\hline & 292 & & & 0.00019 & 0.00113 & 5.9 & 2115 & 2113 & 2116 & 97.7 \\
\hline & 293 & & & 0.00004 & 0.00068 & 13.3 & 2077 & 2074 & 2079 & 28.9 \\
\hline & 294 & & & 0.00063 & 0.00062 & 15.2 & 2068 & 2064 & 2072 & 44.8 \\
\hline & 295 & & & 0.00028 & 0.00028 & 10.4 & 2094 & 2093 & 2095 & 139.0 \\
\hline & 296 & & & 0.00077 & 0.00302 & 30.2 & 2115 & 2106 & 2129 & 3.6 \\
\hline & 297 & & & 0.00091 & 0.00323 & 25.8 & 2281 & 2272 & 2291 & 73.1 \\
\hline & 298 & & & 0.00027 & 0.00157 & 28.9 & 2254 & 2245 & 2266 & 100.8 \\
\hline & 299 & & & 0.00193 & 0.00481 & 36.4 & 2259 & 2242 & 2283 & 35.9 \\
\hline & 300 & & & 0.00094 & 0.00094 & 28.3 & 2286 & 2276 & 2299 & 129.0 \\
\hline & 301 & & & 0.00183 & 0.00458 & 32.1 & 2252 & 2229 & 2274 & 116.4 \\
\hline
\end{tabular}




\begin{tabular}{|c|c|c|c|c|c|c|c|c|c|c|}
\hline $\begin{array}{l}\text { Glacier } \\
\text { Name }\end{array}$ & TS_ID & RECNO & Perennial & $\begin{array}{l}\text { Area } \\
\left(\mathrm{km}^{2}\right)\end{array}$ & $\begin{array}{c}\text { Uncertainty } \\
\left(\mathrm{km}^{2}\right)\end{array}$ & $\mathrm{S}$ & Z & Zmin & $Z \max$ & $\mathrm{D}$ \\
\hline & 302 & & & 0.00028 & 0.00346 & 18.2 & 2162 & 2142 & 2183 & 107.6 \\
\hline & 303 & & & 0.00616 & 0.00771 & 57.8 & 2438 & 2406 & 2473 & 118.8 \\
\hline & 304 & & & 0.00037 & 0.00170 & 16.9 & 2803 & 2798 & 2805 & 11.0 \\
\hline & 305 & & & 0.00001 & 0.00071 & 19.1 & 2816 & 2812 & 2821 & 307.1 \\
\hline & 306 & & $x$ & 0.00362 & 0.00560 & 23.1 & 2816 & 2798 & 2827 & 340.1 \\
\hline & 307 & & & 0.00022 & 0.00140 & 48.7 & 2787 & 2762 & 2814 & 115.7 \\
\hline & 308 & & $x$ & 0.00664 & 0.01051 & 44.4 & 2780 & 2758 & 2816 & 54.3 \\
\hline & 309 & & & 0.01524 & 0.01626 & 47.6 & 2539 & 2520 & 2572 & 130.8 \\
\hline & 310 & & & 0.00516 & 0.00880 & 34.6 & 2791 & 2760 & 2816 & 161.2 \\
\hline & 311 & & & 0.00522 & 0.00711 & 39.2 & 2813 & 2760 & 2869 & 180.6 \\
\hline & 312 & & & 0.00018 & 0.00123 & 36.9 & 2737 & 2730 & 2746 & 52.7 \\
\hline & 313 & & & 0.00008 & 0.00083 & 36.7 & 2113 & 2109 & 2121 & 86.5 \\
\hline & 314 & & & 0.00036 & 0.00036 & 33.3 & 2092 & 2091 & 2093 & 30.0 \\
\hline & 315 & & & 0.00178 & 0.00502 & 27.3 & 2180 & 2160 & 2195 & 26.2 \\
\hline & 316 & & & 0.00493 & 0.00751 & 41.7 & 2243 & 2226 & 2265 & 3.2 \\
\hline & 317 & & & 0.00023 & 0.00248 & 5.5 & 2187 & 2180 & 2194 & 13.1 \\
\hline & 318 & & & 0.00194 & 0.00419 & 29.6 & 2573 & 2530 & 2614 & 57.8 \\
\hline & 319 & & & 0.00067 & 0.00197 & 32.2 & 2251 & 2249 & 2253 & 141.6 \\
\hline & 320 & & & 0.00077 & 0.00360 & 35.3 & 2290 & 2270 & 2307 & 73.0 \\
\hline & 321 & & & 0.00494 & 0.00623 & 28.1 & 2290 & 2264 & 2320 & 43.1 \\
\hline & 322 & & & 0.00491 & 0.00719 & 26.1 & 2234 & 2211 & 2278 & 66.5 \\
\hline & 323 & & & 0.00019 & 0.00115 & 34.1 & 2148 & 2138 & 2159 & 38.5 \\
\hline & 324 & & & 0.00194 & 0.00377 & & 2037 & 2020 & 2057 & 20.4 \\
\hline & 325 & & & 0.00222 & 0.00372 & & 2131 & 2122 & 2147 & 65.1 \\
\hline & 326 & & & 0.00071 & 0.00294 & & 2202 & 2185 & 2223 & 58.0 \\
\hline & 327 & & & 0.00145 & 0.00410 & 48.8 & 2267 & 2246 & 2292 & 111.3 \\
\hline & 328 & & & 0.00184 & 0.00364 & 41.9 & 2227 & 2204 & 2245 & 121.0 \\
\hline & 329 & & & 0.00581 & 0.00708 & 27.4 & 2241 & 2225 & 2266 & 319.9 \\
\hline & 330 & & & 0.00384 & 0.00506 & 24.3 & 2316 & 2310 & 2332 & 330.4 \\
\hline & 331 & & & 0.00087 & 0.00283 & 2.2 & 2181 & 2180 & 2181 & 47.6 \\
\hline & 332 & & & 0.00075 & 0.00221 & 19.0 & 2171 & 2169 & 2175 & 27.2 \\
\hline & 333 & & & 0.00229 & 0.00393 & 31.2 & 2169 & 2152 & 2185 & 10.2 \\
\hline & 334 & & & 0.00276 & 0.00446 & 23.3 & 2159 & 2159 & 2162 & 310.5 \\
\hline & 335 & & & 0.00270 & 0.00723 & 23.7 & 2117 & 2101 & 2138 & 359.3 \\
\hline & 336 & & & 0.00001 & 0.00048 & 24.2 & 2063 & 2061 & 2066 & 336.2 \\
\hline & 337 & & & 0.00032 & 0.00152 & 33.9 & 2121 & 2117 & 2126 & 347.8 \\
\hline & 338 & & & 0.00103 & 0.00466 & 24.9 & 2088 & 2071 & 2103 & 355.9 \\
\hline & 339 & & $x$ & 0.00326 & 0.00548 & 38.5 & 2269 & 2252 & 2292 & 8.5 \\
\hline & 340 & & $x$ & 0.00197 & 0.00532 & 52.5 & 2236 & 2204 & 2285 & 29.6 \\
\hline & 341 & & $x$ & 0.00393 & 0.00677 & 32.6 & 2228 & 2203 & 2260 & 287.6 \\
\hline & 342 & & & 0.00328 & 0.00661 & 8.5 & 2290 & 2287 & 2292 & 9.9 \\
\hline & 343 & & & 0.00194 & 0.00518 & 20.9 & 2259 & 2242 & 2275 & 302.5 \\
\hline & 344 & & & 0.00047 & 0.00199 & 7.8 & 2307 & 2305 & 2309 & 302.7 \\
\hline & 345 & & & 0.00033 & 0.00349 & 17.8 & 2230 & 2208 & 2250 & 306.8 \\
\hline & 346 & & & 0.00002 & 0.00107 & 18.0 & 2168 & 2165 & 2172 & 301.0 \\
\hline & 347 & & & 0.00075 & 0.00463 & 20.3 & 2412 & 2394 & 2437 & 279.7 \\
\hline & 348 & & & 0.00029 & 0.00146 & 27.1 & 2544 & 2537 & 2551 & 243.2 \\
\hline & 349 & & & 0.00003 & 0.00111 & 23.9 & 2364 & 2356 & 2372 & 227.3 \\
\hline
\end{tabular}




\begin{tabular}{|c|c|c|c|c|c|c|c|c|c|c|}
\hline $\begin{array}{l}\text { Glacier } \\
\text { Name }\end{array}$ & TS_ID & RECNO & Perennial & $\begin{array}{l}\text { Area } \\
\left(\mathrm{km}^{2}\right)\end{array}$ & $\begin{array}{c}\text { Uncertainty } \\
\left(\mathrm{km}^{2}\right)\end{array}$ & $S$ & Z & Zmin & $Z \max$ & $\mathrm{D}$ \\
\hline & 350 & & & 0.00363 & 0.00832 & 36.0 & 2813 & 2787 & 2831 & 192.2 \\
\hline & 351 & & & 0.00227 & 0.00516 & 26.1 & 2434 & 2423 & 2449 & 257.3 \\
\hline & 352 & & $x$ & 0.00169 & 0.00599 & 20.6 & 2356 & 2339 & 2372 & 205.2 \\
\hline & 353 & & & 0.00136 & 0.00348 & 22.9 & 2330 & 2320 & 2341 & 195.6 \\
\hline & 354 & & & 0.00090 & 0.00231 & 13.3 & 2334 & 2332 & 2338 & 199.2 \\
\hline & 355 & & & 0.00030 & 0.00193 & 29.5 & 2298 & 2284 & 2311 & 204.1 \\
\hline & 356 & & & 0.00011 & 0.00100 & 12.7 & 2263 & 2259 & 2266 & 191.4 \\
\hline & 357 & & & 0.00038 & 0.00167 & 20.7 & 2289 & 2285 & 2295 & 248.3 \\
\hline & 358 & & $x$ & 0.00273 & 0.00906 & 37.6 & 2246 & 2228 & 2283 & 312.4 \\
\hline & 359 & & & 0.00263 & 0.00432 & 11.5 & 2323 & 2320 & 2326 & 243.2 \\
\hline & 360 & & $x$ & 0.00334 & 0.00478 & 22.7 & 2283 & 2278 & 2287 & 187.3 \\
\hline & 361 & & $x$ & 0.00215 & 0.00620 & 29.8 & 2248 & 2241 & 2259 & 281.1 \\
\hline & 362 & & & 0.00112 & 0.00399 & 27.8 & 2276 & 2273 & 2282 & 289.3 \\
\hline & 363 & & & 0.00031 & 0.00281 & 21.2 & 2242 & 2241 & 2244 & 339.3 \\
\hline & 364 & & & 0.00004 & 0.00131 & 18.2 & 2227 & 2220 & 2232 & 303.0 \\
\hline & 365 & & & 0.00136 & 0.00320 & 29.2 & 2189 & 2180 & 2202 & 300.9 \\
\hline & 366 & & & 0.00966 & 0.00872 & 30.3 & 2282 & 2244 & 2318 & 321.9 \\
\hline & 367 & & & 0.00018 & 0.00198 & 22.3 & 2190 & 2178 & 2202 & 300.9 \\
\hline & 368 & & & 0.00080 & 0.00233 & 14.4 & 2129 & 2125 & 2134 & 356.2 \\
\hline & 369 & & & 0.00028 & 0.00140 & 18.1 & 2275 & 2269 & 2278 & 308.2 \\
\hline & 370 & & & 0.00005 & 0.00102 & 30.8 & 2239 & 2227 & 2248 & 338.6 \\
\hline & 371 & & & 0.00085 & 0.00241 & 27.5 & 2602 & 2592 & 2614 & 174.2 \\
\hline & 372 & & & 0.00098 & 0.00232 & 34.4 & 2544 & 2527 & 2559 & 239.8 \\
\hline & 373 & & & 0.00158 & 0.00505 & 24.7 & 2330 & 2314 & 2353 & 46.7 \\
\hline & 374 & & & 0.00336 & 0.00752 & 41.6 & 2620 & 2588 & 2670 & 118.2 \\
\hline & 375 & & & 0.00001 & 0.00117 & 28.8 & 2343 & 2339 & 2347 & 316.8 \\
\hline & 376 & & & 0.00020 & 0.00219 & 27.4 & 2121 & 2109 & 2137 & 311.2 \\
\hline & 377 & & & 0.00034 & 0.00178 & 14.1 & 2308 & 2303 & 2314 & 209.1 \\
\hline & 378 & & & 0.00154 & 0.00413 & 32.0 & 2254 & 2224 & 2277 & 350.6 \\
\hline & 379 & & & 0.00021 & 0.00241 & 28.1 & 2182 & 2166 & 2196 & 357.5 \\
\hline & 380 & & & & 0.00000 & & & & & \\
\hline & 381 & & & 0.00096 & 0.00234 & 33.1 & 2256 & 2242 & 2273 & 323.4 \\
\hline & 382 & & & 0.00012 & 0.00136 & 30.5 & 2254 & 2240 & 2270 & 309.9 \\
\hline & 383 & & $x$ & 0.00385 & 0.00667 & 36.1 & 2205 & 2194 & 2219 & 58.5 \\
\hline & 384 & & & 0.00149 & 0.00361 & 27.1 & 2193 & 2190 & 2206 & 293.0 \\
\hline & 385 & & & 0.00101 & 0.00323 & 52.0 & 2250 & 2232 & 2289 & 98.3 \\
\hline & 386 & & & 0.00298 & 0.00516 & 38.7 & 2297 & 2272 & 2324 & 358.3 \\
\hline & 387 & & & 0.00097 & 0.00376 & 26.1 & 2174 & 2158 & 2182 & 348.3 \\
\hline & 388 & & & 0.00079 & 0.00079 & 15.5 & 2128 & 2124 & 2132 & 83.2 \\
\hline & 389 & & & 0.00039 & 0.00170 & 38.0 & 2062 & 2049 & 2077 & 16.2 \\
\hline & 390 & & & 0.00070 & 0.00070 & 36.5 & 2503 & 2493 & 2515 & 95.8 \\
\hline & 391 & & & 0.00031 & 0.00156 & 21.1 & 2201 & 2199 & 2204 & 128.8 \\
\hline & 392 & & & 0.00048 & 0.00048 & 9.0 & 2122 & 2121 & 2123 & 19.5 \\
\hline & 393 & & & 0.00026 & 0.00190 & 10.7 & 2276 & 2274 & 2279 & 97.3 \\
\hline & 394 & & & 0.00030 & 0.00157 & 9.6 & 2249 & 2247 & 2251 & 207.2 \\
\hline & 395 & & & 0.00007 & 0.00157 & 21.2 & 2269 & 2265 & 2273 & 212.4 \\
\hline & 396 & & & 0.00051 & 0.00179 & 24.7 & 2337 & 2328 & 2347 & 149.5 \\
\hline & 397 & & & 0.00007 & 0.00124 & 9.9 & 2131 & 2128 & 2132 & 70.4 \\
\hline
\end{tabular}




\begin{tabular}{|c|c|c|c|c|c|c|c|c|c|c|}
\hline $\begin{array}{l}\text { Glacier } \\
\text { Name }\end{array}$ & TS_ID & RECNO & Perennial & $\begin{array}{l}\text { Area } \\
\left(\mathrm{km}^{2}\right)\end{array}$ & $\begin{array}{c}\text { Uncertainty } \\
\left(\mathrm{km}^{2}\right)\end{array}$ & $S$ & Z & $Z \min$ & $Z$ max & $\mathrm{D}$ \\
\hline & 398 & & & 0.00012 & 0.00096 & 22.5 & 2149 & 2146 & 2153 & 354.8 \\
\hline & 399 & & & 0.00001 & 0.00083 & 37.8 & 2195 & 2191 & 2202 & 132.6 \\
\hline & 400 & & & 0.00212 & 0.00505 & 38.1 & 2419 & 2403 & 2438 & 5.7 \\
\hline & 401 & & & 0.00044 & 0.00166 & 19.8 & 2399 & 2396 & 2401 & 204.2 \\
\hline & 402 & & & 0.00831 & 0.00830 & 19.1 & 2151 & 2143 & 2164 & 340.9 \\
\hline & 403 & & & 0.00077 & 0.00277 & 18.2 & 2583 & 2574 & 2593 & 265.5 \\
\hline & 404 & & & 0.00075 & 0.00251 & 22.1 & 2600 & 2592 & 2609 & 290.2 \\
\hline & 405 & & & 0.00074 & 0.00219 & 34.8 & 2627 & 2613 & 2639 & 306.9 \\
\hline & 406 & & & 0.00001 & 0.00051 & 27.8 & 2631 & 2628 & 2635 & 292.3 \\
\hline
\end{tabular}

1990

\begin{tabular}{|c|c|c|c|c|c|c|c|c|c|c|}
\hline $\begin{array}{l}\text { Glacier } \\
\text { Name }\end{array}$ & TS_ID & RECNO & Perennial & $\begin{array}{l}\text { Area } \\
\left(\mathrm{km}^{2}\right)\end{array}$ & $\begin{array}{l}\text { Uncertainty } \\
\left(\mathrm{km}^{2}\right)\end{array}$ & $S$ & Z & Zmin & Zmax & D \\
\hline & 1 & & $x$ & 0.0042637 & 0.00153 & 18.8 & 2416 & 2393 & 2447 & 191.3 \\
\hline & 2 & & & 0.0015591 & 0.00086 & - & - & - & - & - \\
\hline & 3 & & & 0.0025493 & 0.00111 & - & - & - & - & - \\
\hline & 4 & & $x$ & 0.0038495 & 0.00132 & 13.5 & 2333 & 2317 & 2348 & 160.6 \\
\hline & 5 & & $x$ & 0.0068561 & 0.00278 & 18.1 & 2747 & 2727 & 2772 & 206.8 \\
\hline & 6 & & $x$ & 0.0090641 & 0.00376 & 20.0 & 2366 & 2344 & 2408 & 184.2 \\
\hline & 7 & & $x$ & 0.0033007 & 0.00119 & 24.3 & 2270 & 2194 & 2353 & 313.3 \\
\hline & 8 & & $x$ & 0.0259226 & 0.00922 & 24.9 & 2234 & 2202 & 2307 & 116.0 \\
\hline & 9 & & $x$ & 0.008226 & 0.00296 & 19.1 & 2361 & 2342 & 2381 & 315.6 \\
\hline & 10 & & $x$ & 0.0036989 & 0.00222 & 8.7 & 2261 & 2211 & 2309 & 7.5 \\
\hline & 11 & & $x$ & 0.0041175 & 0.00206 & 22.0 & 2382 & 2341 & 2421 & 354.8 \\
\hline & 12 & & $x$ & 0.0047956 & 0.00159 & 18.5 & 2157 & 2132 & 2185 & 14.2 \\
\hline & 13 & & & - & - & - & - & - & - & - \\
\hline & 14 & & & - & - & - & - & - & - & - \\
\hline & 15 & & & - & - & - & - & - & - & - \\
\hline & 16 & & & 0.0014402 & 0.00087 & - & - & - & - & - \\
\hline & 17 & 4194 & $x$ & 0.0012339 & 0.00106 & 15.1 & 2256 & 2227 & 2281 & 358.4 \\
\hline & 18 & 4196 & $x$ & 0.0131051 & 0.00896 & 22.1 & 2168 & 2155 & 2188 & 2.3 \\
\hline & 19 & 4198 & $x$ & 0.0116068 & 0.00266 & 29.6 & 2102 & 2075 & 2138 & 51.4 \\
\hline & 20 & 4201 & $x$ & 0.0112884 & 0.00400 & 35.4 & 2200 & 2184 & 2214 & 82.2 \\
\hline & 21 & 4202 & $x$ & 0.0058816 & 0.00152 & 15.3 & 2272 & 2216 & 2350 & 64.1 \\
\hline & 22 & 4204 & & 0.0017227 & 0.00130 & - & - & - & - & - \\
\hline & 23 & 4205 & $x$ & 0.0016005 & 0.00119 & 25.1 & 2796 & 2776 & 2813 & 260.7 \\
\hline & 24 & 4206 & $x$ & 0.0123325 & 0.00485 & 41.1 & 2968 & 2862 & 3036 & 110.1 \\
\hline \multirow[t]{2}{*}{ Renfrew } & 25 & 4207 & $x$ & 0.45918 & 0.00386 & 23.3 & 2744 & 2621 & 2868 & 249.2 \\
\hline & 26 & 4208 & $x$ & 0.119574 & 0.01962 & 36.5 & 2668 & 2561 & 2754 & 174.5 \\
\hline \multirow[t]{5}{*}{ Collier } & 27 & 4209 & $x$ & 0.88349 & 0.01212 & 31.0 & 2728 & 2624 & 2859 & 155.7 \\
\hline & 28 & 4209 & $x$ & 0.182037 & 0.01732 & 27.0 & 2713 & 2676 & 2750 & 131.8 \\
\hline & 29 & 4210 & $x$ & 0.0275112 & 0.00544 & 24.4 & 2376 & 2352 & 2405 & 93.3 \\
\hline & 30 & 4211 & $\mathrm{x}$ & 0.009151 & 0.00393 & 21.0 & 2163 & 2132 & 2195 & 46.1 \\
\hline & 31 & 4212 & $x$ & 0.0004117 & 0.00058 & 20.8 & 2394 & 2319 & 2466 & 317.6 \\
\hline
\end{tabular}




\begin{tabular}{|c|c|c|c|c|c|c|c|c|c|c|}
\hline $\begin{array}{l}\text { Glacier } \\
\text { Name }\end{array}$ & TS_ID & RECNO & Perennial & $\begin{array}{l}\text { Area } \\
\left(\mathrm{km}^{2}\right)\end{array}$ & $\begin{array}{l}\text { Uncertainty } \\
\left(\mathrm{km}^{2}\right)\end{array}$ & $\mathrm{S}$ & Z & $Z \mathrm{~min}$ & $Z \max$ & D \\
\hline & 32 & 4213 & & - & - & - & - & - & - & - \\
\hline & 33 & 4214 & $x$ & 0.0045474 & 0.00149 & 18.9 & 2623 & 2334 & 2827 & 296.8 \\
\hline \multirow[t]{10}{*}{ Thayer } & 34 & 4216 & $x$ & 0.1050 & 0.03000 & 20.3 & 2561 & 2365 & 2737 & 316.9 \\
\hline & 35 & 4217 & & 0.0002583 & 0.00045 & - & - & - & - & - \\
\hline & 36 & 4219 & $x$ & 0.0043342 & 0.00175 & 18.9 & 2483 & 2177 & 2722 & 349.0 \\
\hline & 37 & 4220 & $x$ & 0.0052948 & 0.00313 & 14.9 & 2700 & 2598 & 2800 & 331.6 \\
\hline & 38 & 4221 & $\mathrm{x}$ & 0.0091976 & 0.00414 & 11.5 & 2563 & 2518 & 2584 & 266.6 \\
\hline & 39 & 4222 & $x$ & 0.0077539 & 0.00421 & 18.0 & 2341 & 2309 & 2415 & 65.6 \\
\hline & 40 & 4223 & $x$ & 0.0034818 & 0.00162 & 11.6 & 2298 & 2290 & 2309 & 110.8 \\
\hline & 41 & 4224 & $\mathrm{x}$ & 0.0043139 & 0.00306 & 14.5 & 2371 & 2336 & 2402 & 131.6 \\
\hline & 42 & 4225 & $x$ & 0.0044381 & 0.00199 & 26.8 & 2275 & 2207 & 2344 & 130.4 \\
\hline & 43 & 4226 & $x$ & 0.0041677 & 0.00347 & 24.6 & 2434 & 2340 & 2640 & 93.6 \\
\hline Villard & 44 & 4227 & $\mathrm{x}$ & 0.044 & 0.00600 & 16.0 & 2149 & 2136 & 2160 & 108.4 \\
\hline \multirow[t]{20}{*}{ Linn } & 45 & 4228 & $x$ & 0.13083 & 0.02313 & 20.2 & 2338 & 2316 & 2368 & 39.3 \\
\hline & 46 & 4229 & & - & - & - & - & - & - & - \\
\hline & 47 & 4233 & $\mathrm{x}$ & 0.0058663 & 0.00213 & 10.5 & 2318 & 2300 & 2341 & 311.5 \\
\hline & 48 & 4234 & $x$ & 0.0105577 & 0.00341 & 18.2 & 2353 & 2310 & 2397 & 299.4 \\
\hline & 49 & 4237 & & - & - & - & - & - & - & - \\
\hline & 50 & 4242 & & - & - & - & - & - & - & - \\
\hline & 51 & 4243 & & - & - & - & - & - & - & - \\
\hline & 52 & 4244 & $\mathrm{x}$ & 0.0162399 & 0.00315 & 17.3 & 2470 & 2432 & 2516 & 279.4 \\
\hline & 53 & 4245 & & - & - & - & - & - & - & - \\
\hline & 54 & 4246 & & - & - & - & - & - & - & - \\
\hline & 55 & 4247 & & - & - & - & - & - & - & - \\
\hline & 56 & 4248 & & - & - & - & - & - & - & - \\
\hline & 57 & 4250 & $\mathrm{x}$ & 0.0570461 & 0.01290 & 17.2 & 2403 & 2382 & 2427 & 272.9 \\
\hline & 59 & 4252 & $x$ & 0.0211188 & 0.00525 & 18.1 & 2434 & 2373 & 2487 & 286.8 \\
\hline & 60 & 4254 & $\mathrm{x}$ & 0.0062305 & 0.00207 & 18.1 & 2481 & 2457 & 2509 & 286.5 \\
\hline & 61 & 4255 & $\mathrm{x}$ & 0.0026877 & 0.00262 & 18.9 & 2311 & 2232 & 2393 & 308.3 \\
\hline & 62 & 4256 & $\mathrm{x}$ & 0.0022154 & 0.00181 & 39.0 & 2773 & 2542 & 2935 & 51.0 \\
\hline & 63 & 4257 & $\mathrm{x}$ & 0.0043194 & 0.00148 & 27.9 & 2507 & 2338 & 2727 & 7.1 \\
\hline & 64 & 4258 & $x$ & 0.0115557 & 0.00302 & 19.3 & 2350 & 2256 & 2466 & 68.4 \\
\hline & 66 & 4260 & $x$ & 0.0386139 & 0.01516 & 30.6 & 2340 & 2271 & 2422 & 336.3 \\
\hline \multirow[t]{6}{*}{ Irving } & 68 & 4262 & $x$ & 0.23707 & 0.00207 & 26.6 & 2356 & 2301 & 2426 & 72.2 \\
\hline & 69 & 4263 & $x$ & 0.0071188 & 0.00172 & 26.4 & 2354 & 2273 & 2507 & 21.2 \\
\hline & 70 & 4264 & $x$ & 0.0484291 & 0.00824 & 13.9 & 2186 & 2182 & 2195 & 81.2 \\
\hline & 71 & 4265 & $x$ & 0.0448504 & 0.01208 & 25.5 & 2144 & 2094 & 2196 & 58.9 \\
\hline & 72 & 4266 & $\mathrm{x}$ & 0.0125101 & 0.00492 & 15.2 & 2224 & 2187 & 2287 & 105.4 \\
\hline & 73 & 4268 & & - & - & - & - & - & - & - \\
\hline \multirow[t]{2}{*}{ Skinner } & 74 & 4270 & $x$ & 0.33117 & 0.02709 & 12.6 & 2236 & 2219 & 2253 & 358.8 \\
\hline & 75 & 4271 & $x$ & 0.05552 & 0.00332 & 24.5 & 2140 & 2107 & 2182 & 33.4 \\
\hline \multirow[t]{6}{*}{ Prouty } & 76 & 4272 & $\mathrm{x}$ & 1.17513 & 0.03630 & 20.6 & 2071 & 2047 & 2122 & 357.3 \\
\hline & 77 & 4273 & $x$ & 0.0954627 & 0.01939 & 17.7 & 2111 & 2092 & 2127 & 58.1 \\
\hline & 78 & 4274 & $\mathrm{x}$ & 0.0037592 & 0.00262 & 16.8 & 2345 & 2282 & 2408 & 78.8 \\
\hline & 80 & 4277 & $x$ & 0.0064555 & 0.00310 & 16.0 & 2161 & 2131 & 2210 & 45.8 \\
\hline & 81 & 4278 & & 0.0033548 & 0.00303 & - & - & - & - & - \\
\hline & 82 & 4280 & $x$ & 0.0052158 & 0.00328 & 12.9 & 2319 & 2290 & 2339 & 172.3 \\
\hline \multirow[t]{2}{*}{ Clark } & 83 & 4281 & $x$ & 0.15034 & 0.05173 & 16.4 & 2264 & 2221 & 2311 & 133.3 \\
\hline & & & & & & & & & & 134 \\
\hline
\end{tabular}




\begin{tabular}{|c|c|c|c|c|c|c|c|c|c|c|}
\hline $\begin{array}{l}\text { Glacier } \\
\text { Name }\end{array}$ & TS_ID & RECNO & Perennial & $\begin{array}{l}\text { Area } \\
\left(\mathrm{km}^{2}\right)\end{array}$ & $\begin{array}{l}\text { Uncertainty } \\
\left(\mathrm{km}^{2}\right)\end{array}$ & $S$ & Z & $Z \min$ & $Z \max$ & $\mathrm{D}$ \\
\hline & 84 & 4282 & & 0.0000684 & 0.00022 & - & - & - & - & - \\
\hline & 85 & 4283 & $x$ & 0.0109124 & 0.00422 & 23.5 & 2460 & 2427 & 2499 & 183.0 \\
\hline & 86 & 4284 & $x$ & 0.0074576 & 0.00244 & 2.9 & 2340 & 2337 & 2341 & 180.0 \\
\hline & 87 & 4286 & $x$ & 0.0003564 & 0.00055 & 19.8 & 2300 & 2276 & 2330 & 319.4 \\
\hline & 88 & 4287 & $x$ & 0.000439 & 0.00075 & 14.4 & 2402 & 2307 & 2496 & 179.6 \\
\hline & 89 & 4288 & $x$ & 0.0120305 & 0.00764 & 15.4 & 2347 & 2205 & 2591 & 127.3 \\
\hline & 90 & 4289 & $x$ & 0.0001661 & 0.00048 & 13.5 & 2359 & 2345 & 2373 & 155.8 \\
\hline & 91 & 4290 & $x$ & 0.0046596 & 0.00449 & 15.0 & 2265 & 2207 & 2312 & 103.4 \\
\hline & 92 & 4291 & $x$ & 0.0141079 & 0.00628 & 18.0 & 2272 & 2126 & 2438 & 115.4 \\
\hline & 93 & 4292 & $x$ & 0.0060951 & 0.00245 & 19.1 & 2159 & 2120 & 2232 & 70.5 \\
\hline \multirow[t]{4}{*}{ Lewis } & 94 & 4293 & $x$ & 0.33407 & 0.01847 & 0.0 & 2135 & 2093 & 2175 & 43.4 \\
\hline & 95 & 4294 & $x$ & 0.0251631 & 0.00821 & 19.6 & 2469 & 2266 & 2751 & 349.6 \\
\hline & 96 & 4295 & $x$ & 0.0979368 & 0.00613 & 24.9 & 2614 & 2487 & 2884 & 29.1 \\
\hline & 97 & 4296 & $x$ & 0.0219892 & 0.00646 & 21.1 & 2617 & 2386 & 2962 & 42.4 \\
\hline \multirow[t]{6}{*}{$\begin{array}{l}\text { Lost } \\
\text { Creek }\end{array}$} & 98 & 4297 & $\mathrm{X}$ & 0.47872 & 0.01627 & 24.6 & 2393 & 2187 & 2618 & 88.0 \\
\hline & 99 & 4298 & $x$ & 0.0309241 & 0.00553 & 32.0 & 2551 & 2475 & 2663 & 85.8 \\
\hline & 100 & 4299 & $x$ & 0.0008929 & 0.00085 & 16.8 & 2258 & 2207 & 2324 & 335.3 \\
\hline & 101 & 4300 & $x$ & 0.0011713 & 0.00082 & - & - & - & - & - \\
\hline & 102 & 4301 & $x$ & 0.0066213 & 0.00332 & 24.3 & 2507 & 2439 & 2577 & 213.2 \\
\hline & 103 & 4302 & $x$ & 0.0152771 & 0.00429 & 20.4 & 2712 & 2519 & 2879 & 218.6 \\
\hline Eugene & 104 & 4304 & $x$ & 0.06017 & 0.02691 & 31.9 & 2567 & 2523 & 2601 & 155.3 \\
\hline \multirow[t]{8}{*}{ Carver } & 105 & 4306 & $x$ & 0.20175 & 0.00228 & 21.4 & 2535 & 2467 & 2643 & 155.6 \\
\hline & 106 & 4307 & $x$ & 0.0138842 & 0.00671 & 30.3 & 2369 & 2334 & 2412 & 100.2 \\
\hline & 107 & 4308 & $x$ & 0.0187037 & 0.00470 & 23.3 & 2346 & 2308 & 2400 & 1.4 \\
\hline & 108 & 4309 & $x$ & 0.037429 & 0.01249 & 22.5 & 2454 & 2319 & 2568 & 285.0 \\
\hline & 109 & 4310 & $x$ & 0.0565664 & 0.01297 & 22.1 & 2469 & 2368 & 2564 & 312.4 \\
\hline & 110 & 4311 & $x$ & 0.0039669 & 0.00149 & 11.3 & 2437 & 2425 & 2462 & 227.3 \\
\hline & 111 & 4329 & & 0.0003261 & 0.00053 & - & - & - & - & - \\
\hline & 112 & 4348 & $x$ & 0.0003584 & 0.00070 & 17.8 & 2546 & 2472 & 2698 & 234.6 \\
\hline Hayden & 113 & 10518 & $x$ & 0.77787 & 0.01439 & 21.2 & 2606 & 2545 & 2706 & 227.5 \\
\hline \multirow[t]{17}{*}{ Diller } & 114 & 10525 & $x$ & 0.59824 & 0.00747 & 22.6 & 2635 & 2585 & 2666 & 237.8 \\
\hline & 115 & & & 0.0001885 & 0.00041 & - & - & - & - & - \\
\hline & 116 & & & 0.0001554 & 0.00026 & - & - & - & - & - \\
\hline & 117 & & & - & - & - & - & - & - & - \\
\hline & 118 & & & - & - & - & - & - & - & - \\
\hline & 119 & & & - & - & - & - & - & - & - \\
\hline & 120 & & $x$ & 0.0014562 & 0.00188 & 18.4 & 2766 & 2605 & 3062 & 145.3 \\
\hline & 121 & & $x$ & 0.002456 & 0.00289 & 22.9 & 3027 & 2944 & 3095 & 94.7 \\
\hline & 122 & & $x$ & 0.0007804 & 0.00114 & 5.7 & 3112 & 3097 & 3131 & 164.4 \\
\hline & 123 & & $x$ & 0.0009651 & 0.00133 & 33.9 & 3085 & 3001 & 3148 & 60.3 \\
\hline & 124 & & $x$ & 0.0069993 & 0.00256 & 20.2 & 2545 & 2274 & 2811 & 324.6 \\
\hline & 125 & & $x$ & 0.0103916 & 0.00227 & 27.4 & 2744 & 2670 & 2864 & 100.6 \\
\hline & 126 & & $x$ & 0.0024749 & 0.00167 & 33.2 & 2462 & 2360 & 2535 & 58.2 \\
\hline & 127 & & $x$ & 0.0005913 & 0.00094 & 16.2 & 2285 & 2250 & 2315 & 306.9 \\
\hline & 128 & & & 0.0001849 & 0.00033 & - & - & - & - & - \\
\hline & 129 & & & 0.0012627 & 0.00069 & - & - & - & - & - \\
\hline & 130 & & $\mathrm{X}$ & 0.0003001 & 0.00035 & 24.6 & 2329 & 2242 & 2398 & 313.8 \\
\hline
\end{tabular}




\begin{tabular}{|c|c|c|c|c|c|c|c|c|c|c|}
\hline $\begin{array}{l}\text { Glacier } \\
\text { Name }\end{array}$ & TS_ID & RECNO & Perennial & $\begin{array}{l}\text { Area } \\
\left(\mathrm{km}^{2}\right)\end{array}$ & $\begin{array}{c}\text { Uncertainty } \\
\left(\mathrm{km}^{2}\right)\end{array}$ & $S$ & Z & Zmin & Zmax & $\mathrm{D}$ \\
\hline & 131 & & & 0.0002026 & 0.00029 & - & - & - & - & - \\
\hline & 132 & & & 0.0000475 & 0.00019 & - & - & - & - & - \\
\hline & 133 & & & 0.0007418 & 0.00082 & - & - & - & - & - \\
\hline & 134 & & & 0.0003281 & 0.00064 & - & - & - & - & - \\
\hline & 135 & & & 0.0002461 & 0.00034 & - & - & - & - & - \\
\hline & 136 & & $x$ & 0.0057219 & 0.00218 & 27.0 & 2415 & 2356 & 2465 & 300.6 \\
\hline & 137 & & $x$ & 0.000392 & 0.00048 & 24.8 & 2522 & 2436 & 2626 & 344.8 \\
\hline & 138 & & & - & - & - & - & - & - & - \\
\hline & 139 & & $x$ & 0.0005208 & 0.00064 & 16.0 & 2328 & 2199 & 2547 & 15.9 \\
\hline & 140 & & & 0.0007245 & 0.00067 & - & - & - & - & - \\
\hline & 141 & & $x$ & 0.0010633 & 0.00099 & 21.5 & 2246 & 2196 & 2302 & 333.0 \\
\hline & 142 & & & 0.0011232 & 0.00100 & - & - & - & - & - \\
\hline & 143 & & & 0.002128 & 0.00168 & - & - & - & - & - \\
\hline & 144 & & & 0.0000725 & 0.00019 & - & - & - & - & - \\
\hline & 145 & & & 0.0010336 & 0.00126 & - & - & - & - & - \\
\hline & 146 & & $x$ & 0.0064823 & 0.00222 & 24.3 & 2356 & 2282 & 2425 & 334.4 \\
\hline & 147 & & & - & - & - & - & - & - & - \\
\hline & 148 & & & 0.0014012 & 0.00078 & - & - & - & - & - \\
\hline & 149 & & & - & - & - & - & - & - & - \\
\hline & 150 & & $x$ & 0.0044427 & 0.00279 & 23.1 & 2344 & 2199 & 2451 & 27.3 \\
\hline & 151 & & & - & - & - & - & - & - & - \\
\hline & 152 & & & 0.0033791 & 0.00235 & - & - & - & - & - \\
\hline & 153 & & & 0.0001226 & 0.00048 & - & - & - & - & - \\
\hline & 154 & & & 0.0007863 & 0.00071 & - & - & - & - & - \\
\hline & 155 & & & 0.0012504 & 0.00113 & - & - & - & - & - \\
\hline & 156 & & & 0.0005859 & 0.00088 & - & - & - & - & - \\
\hline & 157 & & & 0.0000299 & 0.00013 & - & - & - & - & - \\
\hline & 158 & & & 0.0000157 & 0.00008 & - & - & - & - & - \\
\hline & 159 & & & - & - & - & - & - & - & - \\
\hline & 160 & & & 0.0000592 & 0.00019 & - & - & - & - & - \\
\hline & 161 & & & 0.00005 & 0.00005 & - & - & - & - & - \\
\hline & 162 & & & 0.0003542 & 0.00051 & - & - & - & - & - \\
\hline & 163 & & & - & - & - & - & - & - & - \\
\hline & 164 & & & - & - & - & - & - & - & - \\
\hline & 165 & & & - & - & - & - & - & - & - \\
\hline & 166 & & & - & - & - & - & - & - & - \\
\hline & 167 & & $x$ & 0.0015564 & 0.00206 & 19.0 & 2301 & 2230 & 2354 & 68.9 \\
\hline & 168 & & $x$ & 0.0000313 & 0.00017 & 18.0 & 2443 & 2427 & 2459 & 114.7 \\
\hline & 169 & & & - & - & - & - & - & - & - \\
\hline & 170 & & & 0.0000569 & 0.00016 & - & - & - & - & - \\
\hline & 171 & & & 0.0000486 & 0.00015 & - & - & - & - & - \\
\hline & 172 & & & 0.0009369 & 0.00113 & - & - & - & - & - \\
\hline & 173 & & & 0.0002999 & 0.00045 & - & - & - & - & - \\
\hline & 174 & & & - & - & - & - & - & - & - \\
\hline & 175 & & & - & - & - & - & - & - & - \\
\hline & 176 & & & - & - & - & - & - & - & - \\
\hline & 177 & & & - & - & - & - & - & - & - \\
\hline & 178 & & & 0.000029 & 0.00013 & - & - & - & - & - \\
\hline
\end{tabular}




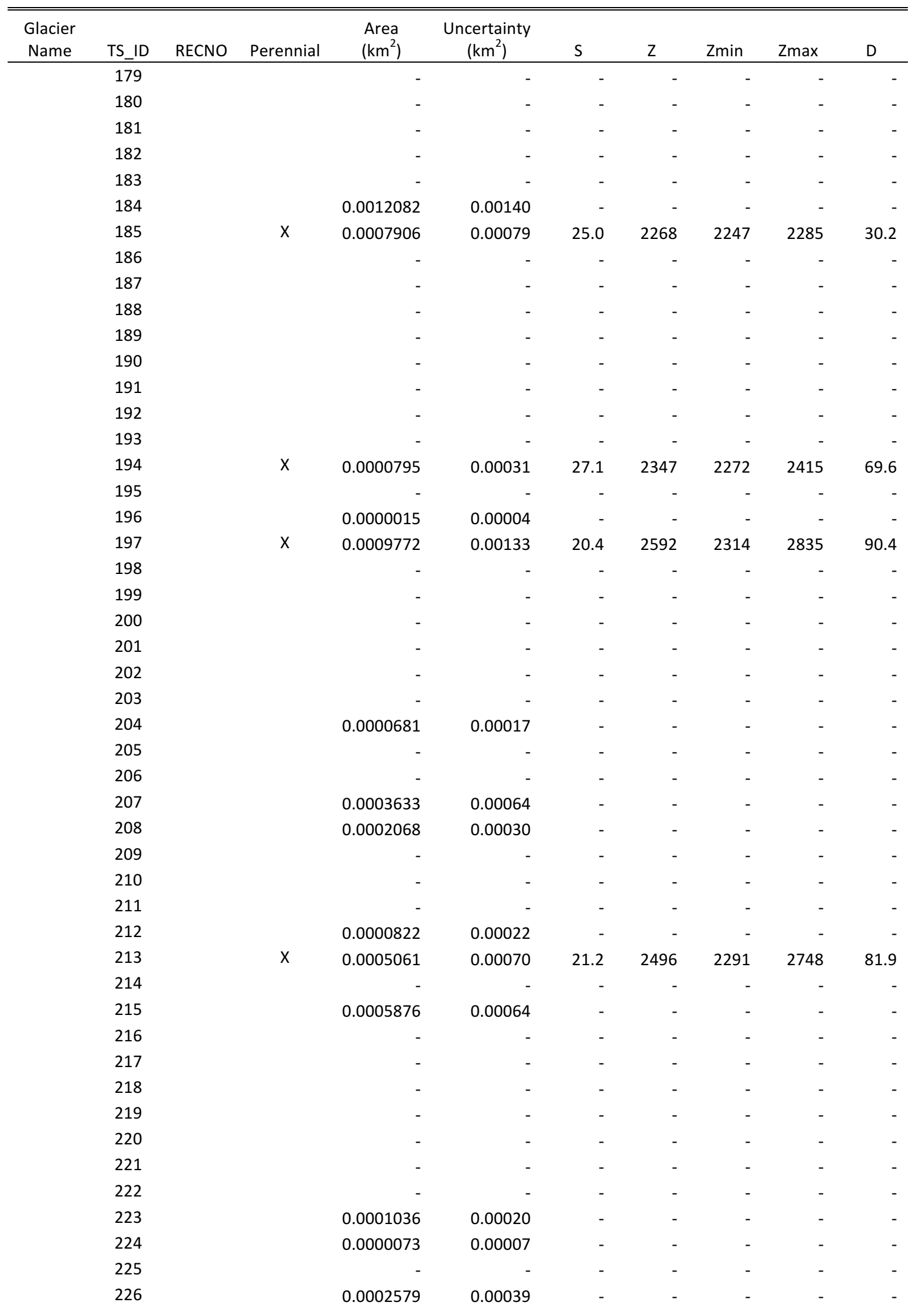




\begin{tabular}{|c|c|c|c|c|c|c|c|c|c|c|}
\hline $\begin{array}{l}\text { Glacier } \\
\text { Name }\end{array}$ & TS_ID & RECNO & Perennial & $\begin{array}{l}\text { Area } \\
\left(\mathrm{km}^{2}\right)\end{array}$ & $\begin{array}{c}\text { Uncertainty } \\
\left(\mathrm{km}^{2}\right)\end{array}$ & $\mathrm{s}$ & z & $Z \mathrm{~min}$ & $Z \max$ & D \\
\hline & 227 & & $x$ & 0.0004835 & 0.00066 & 14.2 & 2293 & 2287 & 2300 & 179.8 \\
\hline & 228 & & & - & & - & - & - & - & - \\
\hline & 229 & & & 0.000176 & 0.00033 & - & - & - & - & - \\
\hline & 230 & & & - & - & - & - & - & - & - \\
\hline & 231 & & & - & - & - & - & - & - & - \\
\hline & 232 & & & - & - & - & - & - & - & - \\
\hline & 233 & & & - & - & - & - & - & - & - \\
\hline & 234 & & & - & - & - & - & - & - & - \\
\hline & 235 & & & - & - & - & - & - & - & - \\
\hline & 236 & & & 0.0000036 & 0.00013 & - & - & - & - & - \\
\hline & 237 & & & - & - & - & - & - & - & - \\
\hline & 238 & & & - & - & - & - & - & - & - \\
\hline & 239 & & & 0.000036 & 0.00019 & - & - & - & - & - \\
\hline & 240 & & & - & - & - & - & - & - & - \\
\hline & 241 & & & 0.000206 & 0.00040 & - & - & - & - & - \\
\hline & 242 & & & - & - & - & - & - & - & - \\
\hline & 243 & & & - & - & - & - & - & - & - \\
\hline & 244 & & & - & - & - & - & - & - & - \\
\hline & 245 & & & - & - & - & - & - & - & - \\
\hline & 246 & & & - & - & - & - & - & - & - \\
\hline & 247 & & $x$ & 0.0014563 & 0.00092 & 15.4 & 2278 & 2270 & 2284 & 148.5 \\
\hline & 248 & & & - & - & - & - & - & - & - \\
\hline & 249 & & & - & - & - & - & - & - & - \\
\hline & 250 & & & 0.0001348 & 0.00030 & - & - & - & - & - \\
\hline & 251 & & & 0.000921 & 0.00109 & - & - & - & - & - \\
\hline & 252 & & & 0.0001148 & 0.00029 & - & - & - & - & - \\
\hline & 253 & & & - & - & - & - & - & - & - \\
\hline & 254 & & & - & - & - & - & - & - & - \\
\hline & 255 & & & - & - & - & - & - & - & - \\
\hline & 256 & & & - & - & - & - & - & - & - \\
\hline & 257 & & & - & - & - & - & - & - & - \\
\hline & 258 & & & - & - & - & - & - & - & - \\
\hline & 259 & & & - & - & - & - & - & - & - \\
\hline & 260 & & & - & - & - & - & - & - & - \\
\hline & 261 & & & - & - & - & - & - & - & - \\
\hline & 262 & & & 0.0000105 & 0.00008 & - & - & - & - & - \\
\hline & 263 & & & 0.0000152 & 0.00011 & - & - & - & - & - \\
\hline & 264 & & & - & - & - & - & - & - & - \\
\hline & 265 & & & - & - & - & - & - & - & - \\
\hline & 266 & & & - & - & - & - & - & - & - \\
\hline & 267 & & & - & - & - & - & - & - & - \\
\hline & 268 & & & - & - & - & - & - & - & - \\
\hline & 269 & & & - & - & - & - & - & - & - \\
\hline & 270 & & & - & - & - & - & - & - & - \\
\hline & 271 & & & 0.0003508 & 0.00038 & - & - & - & - & - \\
\hline & 272 & & & - & - & - & - & - & - & - \\
\hline & 273 & & & - & - & - & - & - & - & - \\
\hline & 274 & & & - & - & - & - & - & - & - \\
\hline
\end{tabular}




\begin{tabular}{|c|c|c|c|c|c|c|c|c|c|c|}
\hline $\begin{array}{l}\text { Glacier } \\
\text { Name }\end{array}$ & TS_ID & RECNO & Perennial & $\begin{array}{l}\text { Area } \\
\left(\mathrm{km}^{2}\right)\end{array}$ & $\begin{array}{c}\text { Uncertainty } \\
\left(\mathrm{km}^{2}\right)\end{array}$ & $\mathrm{s}$ & z & $Z \mathrm{~min}$ & $Z \max$ & D \\
\hline & 275 & & & - & - & - & - & - & - & - \\
\hline & 276 & & & - & - & - & - & - & - & - \\
\hline & 277 & & & - & - & - & - & - & - & - \\
\hline & 278 & & & - & - & - & - & - & - & - \\
\hline & 279 & & & - & - & - & - & - & - & - \\
\hline & 280 & & & 0.0010758 & 0.00119 & - & - & - & - & - \\
\hline & 281 & & & 0.0008394 & 0.00099 & - & - & - & - & - \\
\hline & 282 & & & 0.0000305 & 0.00015 & - & - & - & - & - \\
\hline & 283 & & & - & - & - & - & - & - & - \\
\hline & 284 & & & - & - & - & - & - & - & - \\
\hline & 285 & & & - & - & - & - & - & - & - \\
\hline & 286 & & & - & - & - & - & - & - & - \\
\hline & 287 & & & - & - & - & - & - & - & - \\
\hline & 288 & & & 0.0003746 & 0.00042 & - & - & - & - & - \\
\hline & 289 & & & 0.0000053 & 0.00006 & - & - & - & - & - \\
\hline & 290 & & & 0.0002154 & 0.00048 & - & - & - & - & - \\
\hline & 291 & & & 0.0003297 & 0.00068 & - & - & - & - & - \\
\hline & 292 & & & - & - & - & - & - & - & - \\
\hline & 293 & & & - & - & - & - & - & - & - \\
\hline & 294 & & & - & - & - & - & - & - & - \\
\hline & 295 & & & 0.0000596 & 0.00016 & - & - & - & - & - \\
\hline & 296 & & & 0.0002039 & 0.00028 & - & - & - & - & - \\
\hline & 297 & & & 0.0006885 & 0.00096 & - & - & - & - & - \\
\hline & 298 & & & 0.0001103 & 0.00025 & - & - & - & - & - \\
\hline & 299 & & & - & - & - & - & - & - & - \\
\hline & 300 & & & - & - & - & - & - & - & - \\
\hline & 301 & & & 0.00127 & 0.00080 & - & - & - & - & - \\
\hline & 302 & & & - & - & - & - & - & - & - \\
\hline & 303 & & & 0.0017234 & 0.00086 & - & - & - & - & - \\
\hline & 304 & & & 0.0003968 & 0.00041 & - & - & - & - & - \\
\hline & 305 & & & & & - & - & - & - & - \\
\hline & 306 & & $x$ & 0.0043297 & 0.00159 & 5.4 & 2263 & 2259 & 2266 & 230.2 \\
\hline & 307 & & & 0.0007478 & 0.00073 & - & - & - & - & - \\
\hline & 308 & & $x$ & 0.0051575 & 0.00264 & 5.1 & 2258 & 2256 & 2259 & 190.6 \\
\hline & 309 & & & 0.0031901 & 0.00279 & - & - & - & - & - \\
\hline & 310 & & & 0.0023136 & 0.00089 & - & - & - & - & - \\
\hline & 311 & & & 0.000208 & 0.00053 & - & - & - & - & - \\
\hline & 312 & & & 0.0001314 & 0.00025 & - & - & - & - & - \\
\hline & 313 & & & - & - & - & - & - & - & - \\
\hline & 314 & & & - & - & - & - & - & - & - \\
\hline & 315 & & & - & - & - & - & - & - & - \\
\hline & 316 & & & - & - & - & - & - & - & - \\
\hline & 317 & & & - & - & - & - & - & - & - \\
\hline & 318 & & & - & - & - & - & - & - & - \\
\hline & 319 & & & - & - & - & - & - & - & - \\
\hline & 320 & & & - & - & - & - & - & - & - \\
\hline & 321 & & & - & - & - & - & - & - & - \\
\hline & 322 & & & - & - & - & - & - & - & - \\
\hline
\end{tabular}




\begin{tabular}{|c|c|c|c|c|c|c|c|c|c|c|}
\hline $\begin{array}{l}\text { Glacier } \\
\text { Name }\end{array}$ & TS_ID & RECNO & Perennial & $\begin{array}{l}\text { Area } \\
\left(\mathrm{km}^{2}\right)\end{array}$ & $\begin{array}{c}\text { Uncertainty } \\
\left(\mathrm{km}^{2}\right)\end{array}$ & $\mathrm{S}$ & Z & $Z \mathrm{~min}$ & $Z \max$ & D \\
\hline & 323 & & & - & - & - & - & - & - & - \\
\hline & 324 & & & - & - & - & - & - & - & - \\
\hline & 325 & & & - & - & - & - & - & - & - \\
\hline & 326 & & & - & - & - & - & - & - & - \\
\hline & 327 & & & - & - & - & - & - & - & - \\
\hline & 328 & & & - & - & - & - & - & - & - \\
\hline & 329 & & & 0.0022609 & 0.00171 & - & - & - & - & - \\
\hline & 330 & & & 0.002118 & 0.00113 & - & - & - & - & - \\
\hline & 331 & & & - & - & - & - & - & - & - \\
\hline & 332 & & & - & - & - & - & - & - & - \\
\hline & 333 & & & - & - & - & - & - & - & - \\
\hline & 334 & & & - & - & - & - & - & - & - \\
\hline & 335 & & & - & - & - & - & - & - & - \\
\hline & 336 & & & - & - & - & - & - & - & - \\
\hline & 337 & & & - & - & - & - & - & - & - \\
\hline & 338 & & & - & - & - & - & - & - & - \\
\hline & 339 & & $x$ & 0.0039442 & 0.00121 & 7.6 & 2254 & 2254 & 2254 & 176.0 \\
\hline & 340 & & $x$ & 0.0045588 & 0.00160 & 14.3 & 2386 & 2360 & 2441 & 241.4 \\
\hline & 341 & & $x$ & 0.0021023 & 0.00137 & 16.5 & 2361 & 2310 & 2420 & 257.4 \\
\hline & 342 & & & 0.0009977 & 0.00073 & - & - & - & - & - \\
\hline & 343 & & & 0.0008759 & 0.00057 & - & - & - & - & - \\
\hline & 344 & & & 0.0008648 & 0.00074 & - & - & - & - & - \\
\hline & 345 & & & 0.000039 & 0.00014 & - & - & - & - & - \\
\hline & 346 & & & - & - & - & - & - & - & - \\
\hline & 347 & & & 0.0000798 & 0.00023 & - & - & - & - & - \\
\hline & 348 & & & 0.0000469 & 0.00016 & - & - & - & - & - \\
\hline & 349 & & & - & - & - & - & - & - & - \\
\hline & 350 & & & 0.0017152 & 0.00154 & - & - & - & - & - \\
\hline & 351 & & & 0.0000407 & 0.00013 & - & - & - & - & - \\
\hline & 352 & & $x$ & 0.0002546 & 0.00059 & 27.2 & 2479 & 2403 & 2580 & 265.4 \\
\hline & 353 & & & 0.0004369 & 0.00048 & - & - & - & - & - \\
\hline & 354 & & & - & - & - & - & - & - & - \\
\hline & 355 & & & 0.0000814 & 0.00029 & - & - & - & - & - \\
\hline & 356 & & & - & - & - & - & - & - & - \\
\hline & 357 & & & 0.000019 & 0.00011 & - & - & - & - & - \\
\hline & 358 & & $x$ & 0.0008022 & 0.00129 & 15.4 & 2308 & 2293 & 2325 & 252.0 \\
\hline & 359 & & & 0.0000951 & 0.00022 & - & - & - & - & - \\
\hline & 360 & & $x$ & 0.0003774 & 0.00073 & 23.9 & 2128 & 2100 & 2187 & 354.7 \\
\hline & 361 & & $x$ & 0.0015546 & 0.00090 & 29.8 & 2926 & 2830 & 3000 & 322.5 \\
\hline & 362 & & & 0.0012789 & 0.00113 & - & - & - & - & - \\
\hline & 363 & & & - & - & - & - & - & - & - \\
\hline & 364 & & & - & - & - & - & - & - & - \\
\hline & 365 & & & - & - & - & - & - & - & - \\
\hline & 366 & & & - & - & - & - & - & - & - \\
\hline & 367 & & & - & - & - & - & - & - & - \\
\hline & 368 & & & 0.001193 & 0.00073 & - & - & - & - & - \\
\hline & 369 & & & 0.0007215 & 0.00053 & - & - & - & - & - \\
\hline & 370 & & & 0.0013183 & 0.00093 & - & - & - & - & - \\
\hline
\end{tabular}




\begin{tabular}{|c|c|c|c|c|c|c|c|c|c|c|}
\hline $\begin{array}{l}\text { Glacier } \\
\text { Name }\end{array}$ & TS_ID & RECNO & Perennial & $\begin{array}{l}\text { Area } \\
\left(\mathrm{km}^{2}\right)\end{array}$ & $\begin{array}{c}\text { Uncertainty } \\
\left(\mathrm{km}^{2}\right)\end{array}$ & $\mathrm{s}$ & Z & $Z \mathrm{~min}$ & Zmax & D \\
\hline & 371 & & & 0.0011116 & 0.00066 & - & - & - & - & - \\
\hline & 372 & & & 0.0000597 & 0.00016 & - & - & - & - & - \\
\hline & 373 & & & 0.0002653 & 0.00070 & - & - & - & - & - \\
\hline & 374 & & & 0.0007443 & 0.00131 & - & - & - & - & - \\
\hline & 375 & & & 0.0003471 & 0.00037 & - & - & - & - & - \\
\hline & 376 & & & 0.0001141 & 0.00030 & - & - & - & - & - \\
\hline & 377 & & & 0.0001524 & 0.00025 & - & - & - & - & - \\
\hline & 378 & & & 0.002242 & 0.00117 & - & - & - & - & - \\
\hline & 379 & & & 0.0005371 & 0.00049 & - & - & - & - & - \\
\hline & 380 & & & 0.0011228 & 0.00096 & - & - & - & - & - \\
\hline & 381 & & & 0.0003744 & 0.00037 & - & - & - & - & - \\
\hline & 382 & & & 0.0001306 & 0.00030 & - & - & - & - & - \\
\hline & 383 & & $x$ & 0.0007991 & 0.00096 & 25.4 & 2485 & 2453 & 2517 & 307.7 \\
\hline & 384 & & & 0.0004852 & 0.00081 & - & - & - & - & - \\
\hline & 385 & & & 0.0013552 & 0.00082 & - & - & - & - & - \\
\hline & 386 & & & 0.0005452 & 0.00074 & - & - & - & - & - \\
\hline & 387 & & & 0.0006705 & 0.00058 & - & - & - & - & - \\
\hline & 388 & & & 0.0000441 & 0.00014 & - & - & - & - & - \\
\hline & 389 & & & 0.0001368 & 0.00023 & - & - & - & - & - \\
\hline & 390 & & & 0.000155 & 0.00029 & - & - & - & - & - \\
\hline & 391 & & & - & - & - & - & - & - & - \\
\hline & 392 & & & - & - & - & - & - & - & - \\
\hline & 393 & & & 0.0001052 & 0.00000 & - & - & - & - & - \\
\hline & 394 & & & - & - & - & - & - & - & - \\
\hline & 395 & & & - & - & - & - & - & - & - \\
\hline & 396 & & & - & - & - & - & - & - & - \\
\hline & 397 & & & 0.0000531 & 0.00027 & - & - & - & - & - \\
\hline & 398 & & & 0.0000925 & 0.00019 & - & - & - & - & - \\
\hline & 399 & & & - & - & - & - & - & - & - \\
\hline & 400 & & & - & - & - & - & - & - & - \\
\hline & 401 & & & 0.0014912 & 0.00093 & - & - & - & - & - \\
\hline & 402 & & & 0.0016251 & 0.00105 & - & - & - & - & - \\
\hline & 403 & & & 0.000693 & 0.00060 & - & - & - & - & - \\
\hline & 404 & & & 0.0005469 & 0.00065 & - & - & - & - & - \\
\hline & 405 & & & 0.0004472 & 0.00043 & - & - & - & - & - \\
\hline & 406 & & & 0.000016 & 0.00009 & - & - & - & - & - \\
\hline
\end{tabular}

2003

\begin{tabular}{|c|c|c|c|c|c|c|c|c|c|c|}
\hline $\begin{array}{l}\text { Glacier } \\
\text { Name }\end{array}$ & TS_ID & RECNO & Perennial & $\begin{array}{l}\text { Area } \\
\left(\mathrm{km}^{2}\right)\end{array}$ & $\begin{array}{l}\text { Uncertainty } \\
\left(\mathrm{km}^{2}\right)\end{array}$ & $S$ & Z & Zmin & Zmax & D \\
\hline & 1 & & $x$ & 0.00669 & 0.00403 & - & - & - & - & - \\
\hline & 4 & & $x$ & 0.00340 & 0.00256 & - & - & - & - & - \\
\hline & 5 & & $x$ & 0.00934 & 0.00613 & - & - & - & - & - \\
\hline
\end{tabular}




\begin{tabular}{|c|c|c|c|c|c|c|c|c|c|c|}
\hline $\begin{array}{l}\text { Glacier } \\
\text { Name }\end{array}$ & TS_ID & RECNO & Perennial & $\begin{array}{l}\text { Area } \\
\left(\mathrm{km}^{2}\right)\end{array}$ & $\begin{array}{c}\text { Uncertainty } \\
\left(\mathrm{km}^{2}\right)\end{array}$ & $S$ & Z & $Z \min$ & $Z \max$ & $\mathrm{D}$ \\
\hline & 6 & & $x$ & 0.00656 & 0.00575 & - & - & - & - & - \\
\hline & 7 & & $x$ & 0.00317 & 0.00226 & - & - & - & - & - \\
\hline & 8 & & $x$ & 0.01935 & 0.01620 & - & - & - & - & - \\
\hline & 9 & & $x$ & 0.00657 & 0.00459 & - & - & - & - & - \\
\hline & 10 & & $x$ & 0.00371 & 0.00397 & - & - & - & - & - \\
\hline & 11 & & $x$ & 0.00638 & 0.00455 & - & - & - & - & - \\
\hline & 12 & & $x$ & 0.00415 & 0.00303 & - & - & - & - & - \\
\hline & 17 & 4194 & $x$ & 0.00078 & 0.00128 & - & - & - & - & - \\
\hline & 18 & 4196 & $x$ & 0.02358 & 0.02194 & - & - & - & - & - \\
\hline & 19 & 4198 & $x$ & 0.00428 & 0.00371 & - & - & - & - & - \\
\hline & 20 & 4201 & $x$ & 0.01222 & 0.00599 & - & - & - & - & - \\
\hline & 21 & 4202 & $x$ & 0.00534 & 0.00292 & - & - & - & - & - \\
\hline & 23 & 4205 & $x$ & 0.00046 & 0.00092 & - & - & - & - & - \\
\hline & 24 & 4206 & $x$ & 0.01380 & 0.00949 & - & - & - & - & - \\
\hline \multirow[t]{2}{*}{ Renfrew } & 25 & 4207 & $x$ & 0.47160 & 0.00532 & - & - & - & - & - \\
\hline & 26 & 4208 & $x$ & 0.12180 & 0.03855 & - & - & - & - & - \\
\hline \multirow[t]{6}{*}{ Collier } & 27 & 4209 & $x$ & 0.78968 & 0.03180 & - & - & - & - & - \\
\hline & 28 & 4209 & $x$ & 0.19970 & 0.03294 & - & - & - & - & - \\
\hline & 29 & 4210 & $x$ & 0.02496 & 0.01132 & - & - & - & - & - \\
\hline & 30 & 4211 & $x$ & 0.01351 & 0.01008 & - & - & - & - & - \\
\hline & 31 & 4212 & $x$ & 0.00133 & 0.00174 & - & - & - & - & - \\
\hline & 33 & 4214 & $x$ & 0.00315 & 0.00206 & - & - & - & - & - \\
\hline \multirow[t]{9}{*}{ Thayer } & 34 & 4216 & $x$ & 0.11418 & 0.02988 & - & - & - & - & - \\
\hline & 36 & 4219 & $x$ & 0.00334 & 0.00320 & - & - & - & - & - \\
\hline & 37 & 4220 & $x$ & 0.00707 & 0.00622 & - & - & - & - & - \\
\hline & 38 & 4221 & $x$ & 0.01011 & 0.00775 & - & - & - & - & - \\
\hline & 39 & 4222 & $x$ & 0.00863 & 0.00791 & - & - & - & - & - \\
\hline & 40 & 4223 & $x$ & 0.00359 & 0.00338 & - & - & - & - & - \\
\hline & 41 & 4224 & $x$ & 0.00470 & 0.00571 & - & - & - & - & - \\
\hline & 42 & 4225 & $x$ & 0.00428 & 0.00392 & - & - & - & - & - \\
\hline & 43 & 4226 & $x$ & 0.00445 & 0.00531 & - & - & - & - & - \\
\hline Villard & 44 & 4227 & $x$ & 0.02088 & 0.00623 & - & - & - & - & - \\
\hline \multirow[t]{12}{*}{ Lynn } & 45 & 4228 & $x$ & 0.13433 & 0.00875 & - & - & - & - & - \\
\hline & 47 & 4233 & $x$ & 0.00992 & 0.00479 & - & - & - & - & - \\
\hline & 48 & 4234 & $x$ & 0.00642 & 0.00522 & - & - & - & - & - \\
\hline & 52 & 4244 & $x$ & 0.01212 & 0.00636 & - & - & - & - & - \\
\hline & 57 & 4250 & $x$ & 0.05945 & 0.02389 & - & - & - & - & - \\
\hline & 59 & 4252 & $x$ & 0.01736 & 0.01055 & - & - & - & - & - \\
\hline & 60 & 4254 & $x$ & 0.00233 & 0.00283 & - & - & - & - & - \\
\hline & 61 & 4255 & $x$ & 0.00201 & 0.00332 & - & - & - & - & - \\
\hline & 62 & 4256 & $x$ & 0.00320 & 0.00298 & - & - & - & - & - \\
\hline & 63 & 4257 & $x$ & 0.00637 & 0.00416 & - & - & - & - & - \\
\hline & 64 & 4258 & $x$ & 0.01367 & 0.00650 & - & - & - & - & - \\
\hline & 66 & 4260 & $x$ & 0.05654 & 0.03095 & - & - & - & - & - \\
\hline \multirow[t]{4}{*}{ Irving } & 68 & 4262 & $x$ & 0.21420 & 0.05653 & - & - & - & - & - \\
\hline & 69 & 4263 & $x$ & 0.00962 & 0.00368 & - & - & - & - & - \\
\hline & 70 & 4264 & $x$ & 0.04490 & 0.01488 & - & - & - & - & - \\
\hline & 71 & 4265 & $x$ & 0.03716 & 0.02240 & - & - & - & - & - \\
\hline
\end{tabular}




\begin{tabular}{|c|c|c|c|c|c|c|c|c|c|c|}
\hline $\begin{array}{l}\text { Glacier } \\
\text { Name }\end{array}$ & TS_ID & RECNO & Perennial & $\begin{array}{l}\text { Area } \\
\left(\mathrm{km}^{2}\right)\end{array}$ & $\begin{array}{l}\text { Uncertainty } \\
\left(\mathrm{km}^{2}\right)\end{array}$ & $\mathrm{S}$ & Z & $Z \min$ & Zmax & $\mathrm{D}$ \\
\hline & 72 & 4266 & $x$ & 0.00854 & 0.00725 & - & - & - & - & - \\
\hline \multirow[t]{2}{*}{ Skinner } & 74 & 4270 & $x$ & 0.30733 & 0.01323 & - & - & - & - & - \\
\hline & 75 & 4271 & $x$ & 0.03487 & 0.01234 & - & - & - & - & - \\
\hline \multirow[t]{5}{*}{ Prouty } & 76 & 4272 & $x$ & 1.11460 & 0.03902 & - & - & - & - & - \\
\hline & 77 & 4273 & $x$ & 0.10039 & 0.04084 & - & - & - & - & - \\
\hline & 78 & 4274 & $x$ & 0.01027 & 0.00964 & - & - & - & - & - \\
\hline & 80 & 4277 & $x$ & 0.00700 & 0.00733 & - & - & - & - & - \\
\hline & 82 & 4280 & $x$ & 0.00306 & 0.00429 & - & - & - & - & - \\
\hline \multirow[t]{10}{*}{ Clark } & 83 & 4281 & $x$ & 0.16636 & 0.04235 & - & - & - & - & - \\
\hline & 85 & 4283 & $x$ & 0.01663 & 0.01006 & - & - & - & - & - \\
\hline & 86 & 4284 & $x$ & 0.00717 & 0.00473 & - & - & - & - & - \\
\hline & 87 & 4286 & $x$ & 0.00161 & 0.00148 & - & - & - & - & - \\
\hline & 88 & 4287 & $x$ & 0.00356 & 0.00479 & - & - & - & - & - \\
\hline & 89 & 4288 & $x$ & 0.02259 & 0.01655 & - & - & - & - & - \\
\hline & 90 & 4289 & $x$ & 0.00271 & 0.00332 & - & - & - & - & - \\
\hline & 91 & 4290 & $x$ & 0.01071 & 0.00909 & - & - & - & - & - \\
\hline & 92 & 4291 & $x$ & 0.01122 & 0.01113 & - & - & - & - & - \\
\hline & 93 & 4292 & $x$ & 0.00783 & 0.00565 & - & - & - & - & - \\
\hline \multirow[t]{4}{*}{ Lewis } & 94 & 4293 & $x$ & 0.30421 & 0.00651 & - & - & - & - & - \\
\hline & 95 & 4294 & $x$ & 0.01076 & 0.00783 & - & - & - & - & - \\
\hline & 96 & 4295 & $x$ & 0.09330 & 0.01190 & - & - & - & - & - \\
\hline & 97 & 4296 & $x$ & 0.00760 & 0.00722 & - & - & - & - & - \\
\hline \multirow[t]{6}{*}{$\begin{array}{l}\text { Lost } \\
\text { Creek }\end{array}$} & 98 & 4297 & $x$ & 0.49016 & 0.04186 & - & - & - & - & - \\
\hline & 99 & 4298 & $x$ & 0.02791 & 0.00916 & - & - & - & - & - \\
\hline & 100 & 4299 & $x$ & 0.00182 & 0.00281 & - & - & - & - & - \\
\hline & 101 & 4300 & $x$ & 0.00163 & 0.00183 & - & - & - & - & - \\
\hline & 102 & 4301 & $x$ & 0.00949 & 0.00590 & - & - & - & - & - \\
\hline & 103 & 4302 & $x$ & 0.01878 & 0.00845 & - & - & - & - & - \\
\hline Eugene & 104 & 4304 & $x$ & 0.06766 & 0.02366 & - & - & - & - & - \\
\hline \multirow[t]{7}{*}{ Carver } & 105 & 4306 & $x$ & 0.16976 & 0.05968 & - & - & - & - & - \\
\hline & 106 & 4307 & $x$ & 0.01521 & 0.01141 & - & - & - & - & - \\
\hline & 107 & 4308 & $x$ & 0.02461 & 0.01300 & - & - & - & - & - \\
\hline & 108 & 4309 & $x$ & 0.02356 & 0.01709 & - & - & - & - & - \\
\hline & 109 & 4310 & $x$ & 0.04160 & 0.02132 & - & - & - & - & - \\
\hline & 110 & 4311 & $x$ & 0.00685 & 0.00407 & - & - & - & - & - \\
\hline & 112 & 4348 & $x$ & 0.00393 & 0.00409 & - & - & - & - & - \\
\hline Hayden & 113 & 10518 & $x$ & 0.73048 & 0.00176 & - & - & - & - & - \\
\hline \multirow[t]{10}{*}{ Diller } & 114 & 10525 & $x$ & 0.55070 & 0.06031 & - & - & - & - & - \\
\hline & 120 & & $x$ & 0.00194 & 0.00303 & - & - & - & - & - \\
\hline & 121 & & $x$ & 0.00300 & 0.00407 & - & - & - & - & - \\
\hline & 122 & & $x$ & 0.00206 & 0.00309 & - & - & - & - & - \\
\hline & 123 & & $x$ & 0.00050 & 0.00083 & - & - & - & - & - \\
\hline & 124 & & $x$ & 0.00476 & 0.00366 & - & - & - & - & - \\
\hline & 125 & & $x$ & 0.01482 & 0.00530 & - & - & - & - & - \\
\hline & 126 & & $x$ & 0.00338 & 0.00359 & - & - & - & - & - \\
\hline & 127 & & $x$ & 0.00133 & 0.00210 & - & - & - & - & - \\
\hline & 130 & & $x$ & 0.00242 & 0.00262 & - & - & - & - & - \\
\hline
\end{tabular}




\begin{tabular}{|c|c|c|c|c|c|c|c|c|c|c|}
\hline $\begin{array}{l}\text { Glacier } \\
\text { Name }\end{array}$ & TS_ID & RECNO & Perennial & $\begin{array}{l}\text { Area } \\
\left(\mathrm{km}^{2}\right)\end{array}$ & $\begin{array}{c}\text { Uncertainty } \\
\left(\mathrm{km}^{2}\right)\end{array}$ & $\mathrm{S}$ & Z & Zmin & $Z \max$ & $\mathrm{D}$ \\
\hline & 136 & & $x$ & 0.00740 & 0.00871 & - & - & - & - & - \\
\hline & 137 & & $x$ & 0.00224 & 0.00275 & - & - & - & - & - \\
\hline & 139 & & $x$ & 0.00039 & 0.00075 & - & - & - & - & - \\
\hline & 141 & & $x$ & 0.00009 & 0.00023 & - & - & - & - & - \\
\hline & 146 & & $x$ & 0.00278 & 0.00204 & - & - & - & - & - \\
\hline & 150 & & $x$ & 0.00507 & 0.00489 & - & - & - & - & - \\
\hline & 167 & & $\mathrm{x}$ & 0.00177 & 0.00294 & - & - & - & - & - \\
\hline & 168 & & $x$ & 0.00000 & & - & - & - & - & - \\
\hline & 185 & & $x$ & 0.00207 & 0.00228 & - & - & - & - & - \\
\hline & 194 & & $\mathrm{x}$ & 0.00080 & 0.00131 & - & - & - & - & - \\
\hline & 197 & & $x$ & 0.00030 & 0.00051 & - & - & - & - & - \\
\hline & 213 & & $\mathrm{x}$ & 0.00108 & 0.00158 & - & - & - & - & - \\
\hline & 227 & & $\mathrm{x}$ & 0.00013 & 0.00039 & - & - & - & - & - \\
\hline & 247 & & $x$ & 0.00178 & 0.00187 & - & - & - & - & - \\
\hline & 306 & & $x$ & 0.00426 & 0.00281 & - & - & - & - & - \\
\hline & 308 & & $x$ & 0.00444 & 0.00414 & - & - & - & - & - \\
\hline & 339 & & $x$ & 0.00305 & 0.00194 & - & - & - & - & - \\
\hline & 340 & & $x$ & 0.00267 & 0.00292 & - & - & - & - & - \\
\hline & 341 & & $x$ & 0.00113 & 0.00150 & - & - & - & - & - \\
\hline & 352 & & $x$ & 0.00025 & 0.00065 & - & - & - & - & - \\
\hline & 358 & & $\mathrm{x}$ & 0.00237 & 0.00284 & - & - & - & - & - \\
\hline & 360 & & $x$ & 0.00073 & 0.00142 & - & - & - & - & - \\
\hline & 361 & & $x$ & 0.00217 & 0.00208 & - & - & - & - & - \\
\hline & 383 & & $x$ & 0.00284 & 0.00283 & - & - & - & - & - \\
\hline
\end{tabular}

